\title{
Ingus Skadiņš
}

\section{AR ANTIBIOTISKĀM VIELĀM IMPREGNĒTU KOMPOZĪTMATERIĀLU ANTIBAKTERIĀLĀ DARBĪBA IN VITRO UN IN VIVO}

Promocijas darbs medicinas doktora zinātniskā grāda iegūšanai Specialitāte - mikrobioloǵija 


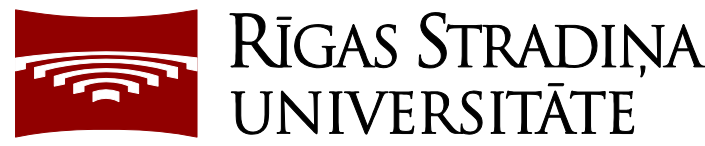

Ingus Skadin̄šs

\title{
AR ANTIBIOTISKĀM VIELĀM IMPREGNĒTU KOMPOZĪTMATERIĀLU ANTIBAKTERIĀLĀ DARBĪBA IN VITRO UN IN VIVO
}

\author{
Promocijas darbs \\ medicīnas doktora zinātniskā grāda iegūšanai \\ Specialitāte - mikrobiologija
}

Darba zinātniskās vadītājas:

Dr. med. profesore Juta Kroiča

Dr. med. docente Ilze Šalma

Daḷējs pētījuma finansējums saņemts VPP 4 "Jauni materiāli un tehnologijas biologisko audu izvērtēšanai un aizvietošanai" ietvaros 


\section{SATURS}

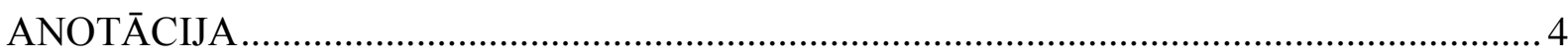

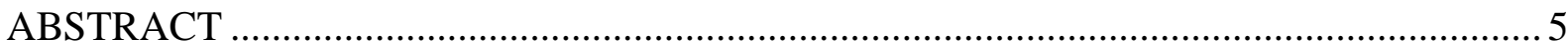

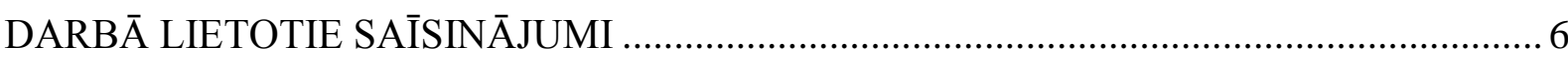

IEVADS ...

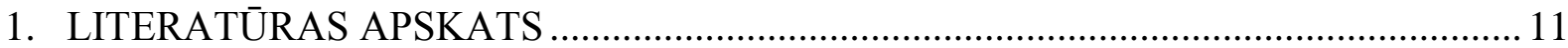

1.1. Antibiotisko vielu vēsture, pielietojums un antibakteriālā rezistence .......................... 11

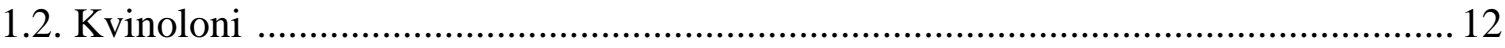

1.2.1. Ciprofloksacīna pielietojums...................................................................... 13

1.2.2. Ciprofloksacīna darbības mehānisms .......................................................... 13

1.2.3. Ciprofloksacīna darbības spektrs............................................................. 14

1.2.4. Ciprofloksacīna farmakokinētika un termostabilitāte ........................................ 14

1.2.5. Baktēriju rezistences mehānismi pret ciprofloksacīnu......................................... 15

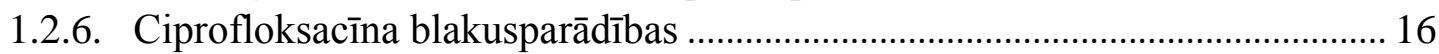

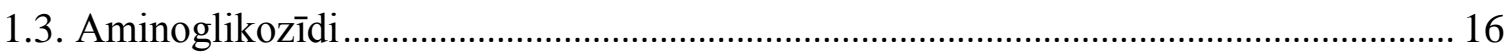

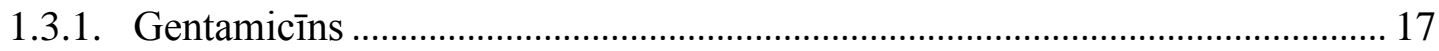

1.3.2. Gentamicīna darbības mehānisms.................................................................... 17

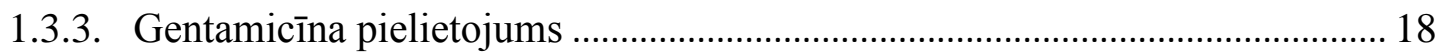

1.3.4. Gentamicīna farmakokinētika ....................................................................... 18

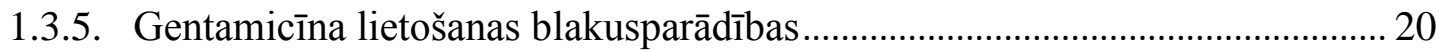

1.3.6. Baktēriju rezistences mehānismi pret gentamicīnu ............................................ 19

1.4. Biomateriālu veidi un pielietojums ............................................................................. 19

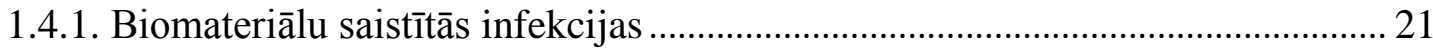

1.4.2. Biomateriālu saisțitās infekciju ierosinātāji un biežums ...................................... 23

1.5. Iekaisums un iekaisuma marķieri. Antibakteriālie peptīdi .............................................. 25

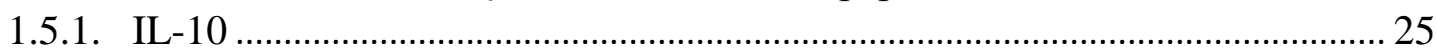

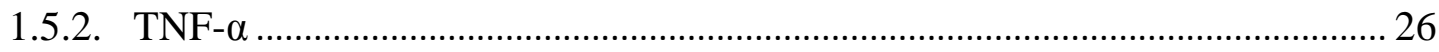

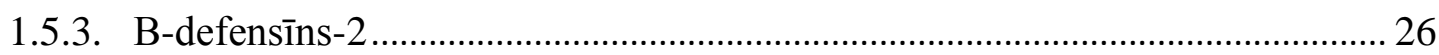

1.6. S. epidermidis un P. aeruginosa raksturojums, patogentitātes faktori un

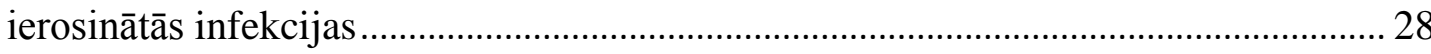

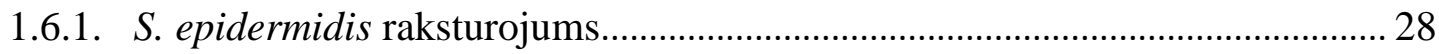

1.6.2. S. epidermidis patogenitātes faktori un ierosinātās infekcijas............................ 28

1.6.3. S. epidermidis biofilmas veidošanās process ...……………………………..... 29

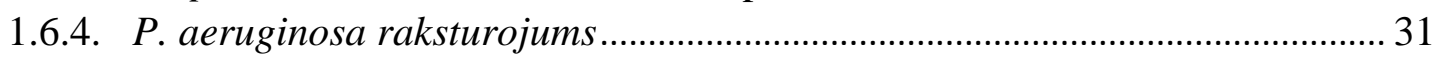

1.6.5. P. aeruginosa patogenitātes faktori un ierosinātās infekcijas .......................... 32

1.6.6. P. aeruginosa biofilmas veidošanās process .................................................... 33

1.7. Bionoārdāmie polimēri, to raksturojums..................................................................... 35

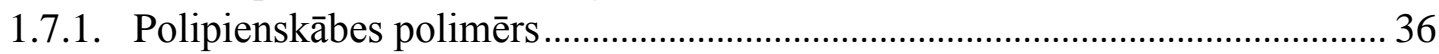

1.7.2. Polikaprolaktona polimērs ……………………………………………………......... 37

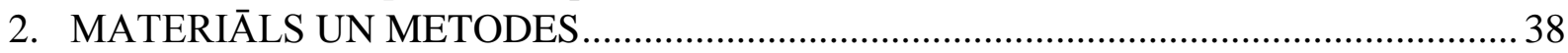

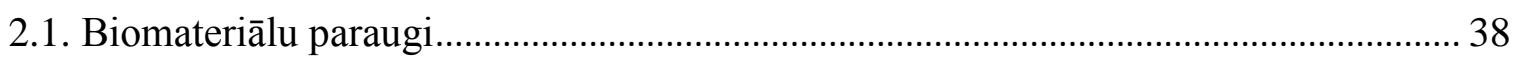

2.1.1. HAp/PLLA+cipro un HAp/PLLA+genta ..................................................... 38

2.1.2. CDHAp/PCL+cipro, CDHAp/PCL+genta, CDHAp/PLLA+cipro un

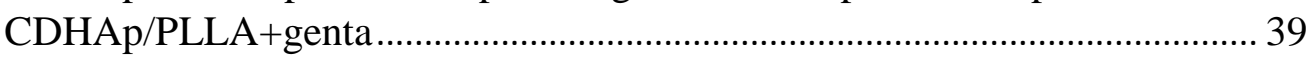

2.2. Antibakteriālo īpašǐbu noteikšana in vitro ………………………………………….... 40

2.2.1. Antibakteriālo īpašǐbu noteikšana baktēriju suspensijā .................................. 40

2.2.2. Antibakteriālo īpašǐbu noteikšana ar disku difūzijas metodi............................. 41 
2.3. Izmeklējamās baktēriju kultūras un to jutība pret gentamicīnu un ciprofloksacīnu .. 42

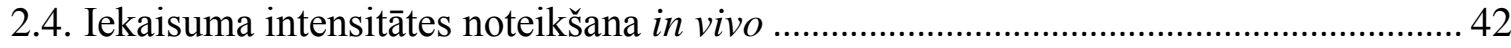

2.4.1. Eksperimentā izmantotie dz̄̄vnieki ..................................................................... 42

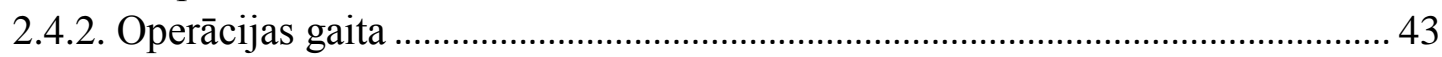

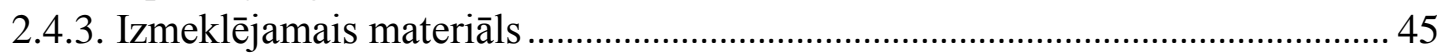

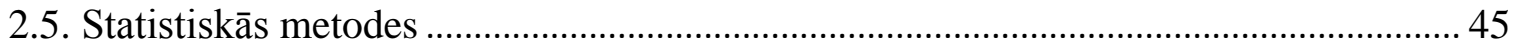

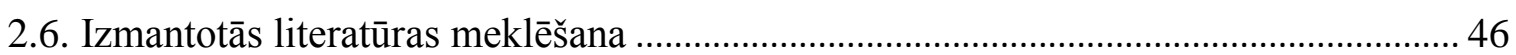

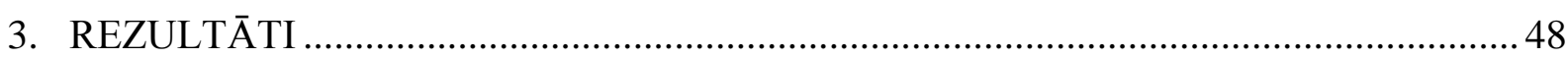

3.1. Antibiotisko vielu minimāli inhibējošā koncentrācija.......................................... 48

3.2. HAp/PLLA+genta un HAp/PLLA+cipro antibakteriālā

3.3. CDHAp/PLLA+genta un CDHAp/PLLA+cipro antibakteriālā

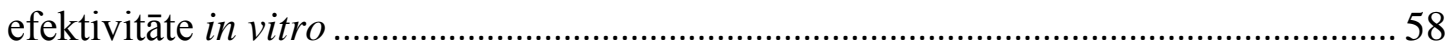

3.4. CDHAp/PCL+genta un CDHAp/PCL+cipro antibakteriālā

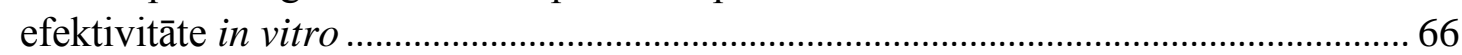

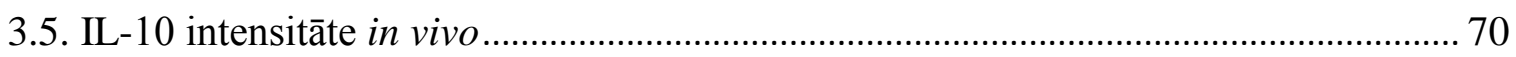

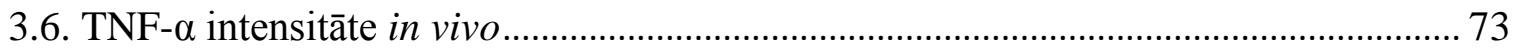

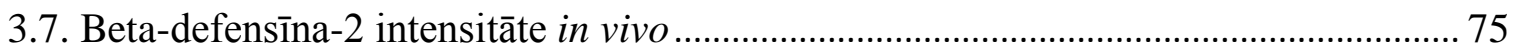

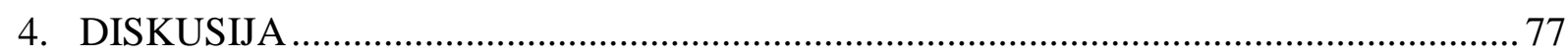

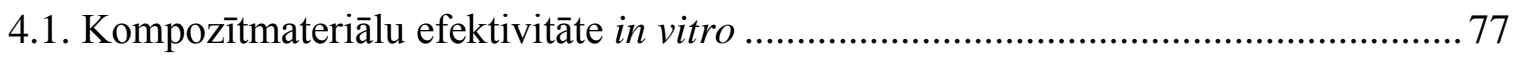

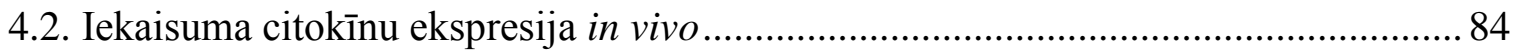

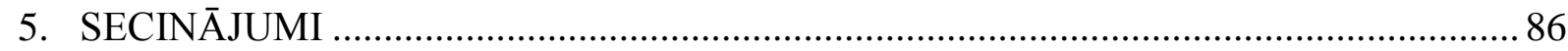

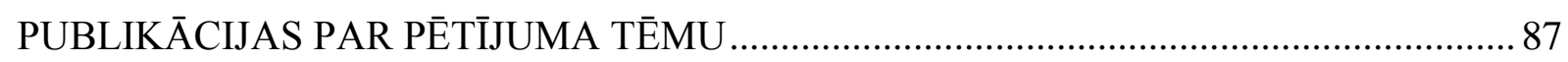

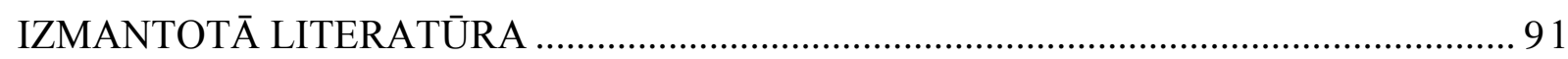

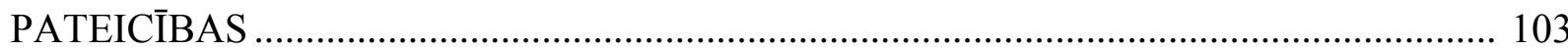

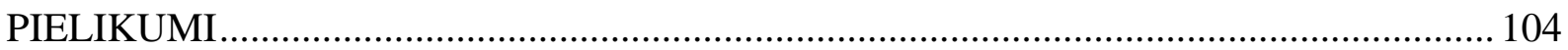




\begin{abstract}
ANOTĀCIJA
Mūsdienās biomateriālus izmanto bieži, un to aktualitāte kḷūst arvien nozīmīgāka, jo biomateriālus izmanto visās medicīnas nozarēs, turklāt nereti to lietošana ir dz̄īīibu glābjoša nepieciešamība.

Taču biomateriālu plašais izmantojums, dažādie biomateriālu veidi un pielietojums ir saistīts ar būtisku medicīnisku problēmu - biomateriālu saistītām infekcijām. Atkarībā no infekcijas veida un lokalizācijas var palielināties pacienta letalitātes risks un kopējās ārstnieciskās izmaksas, jo implantātu bieži nākas aizvietot ar jaunu. Lai novērstu biomateriālu infekcijas, ir jāsamazina baktēriju adhēzija un biofilmu veidošanās. To iespējams panākt, biomateriālam pievienojot antibiotiskās vielas. Lokālai antibiotisko vielu izdalei no biomateriāla ir daudz priekšrocību, salīdzinot ar sistēmisko antibiotisko vielu nozīmēšanu pacientiem pirms un pēc implantācijas operācijas.

$\breve{S}_{1} \overline{1}$ darba mērķis ir noskaidrot kompozītmateriālu ar antibiotiskajām vielām (gentamicīnu vai ciprofloksacīnu) un biodegradējamu polimēru antibakteriālo efektivitāti pret vienu no biežākajiem pēcoperācijas infekciju ierosinātājiem - Pseudomonas aeruginosa (P. aeruginosa) un Staphylococcus epidermidis (S. epidermidis), kā arī salīdzināt antibakteriālās īpašības kompozītmateriāliem ar biodegradējamu polimēru un bez tā.

Biomateriālu antibakteriālās īpašības pret $S$. epidermidis un $P$. aeruginosa tika pêtītas, izmantojot standartizēto disku difūzijas metodi agara barotnē, kā arī baktēriju suspensijā.

Iekaisuma citokīnu (TNF- $\alpha$ un IL-10) un antibakteriālo peptīdu ( $\beta$-defensīna-2) intensitāte audos ap implantēto biomateriālu tika izvērtēta in vivo pētījumā pēc biomateriālu paraugu implantācijas truša zemādas kabatā un kontaminācijas ar S. epidermidis vai P. aeruginosa.

Rezultāti atklāja, ka biomateriāliem ar bionoārdāmo polimēru un antibiotiskajām vielām antibakteriālās darbības laiks ir statistiski ticami ilgāks nekā biomateriāliem ar antibiotiskajām vielām bez bionoārdāma polimēra. Antibakteriālās darbības laiku neietekmē metode, ar kādu nosaka biomateriālu antibakteriālās īpašības, bet to būtiski ietekmē biomateriālu porainības līmenis, jo biomateriāliem ar zemāku porainības līmeni ir statistiski ticami īsāks antibakteriālās darbības laiks nekā biomateriāliem ar augstāku porainības līmeni.

In vivo pētījuma rezultāti rāda, ka pēc antibiotisko vielu saturošu kompozītmateriālu implantācijas apkārtējos audos ap biomateriālu nenovēro paaugstinātu iekaisuma citokīnu un antibakteriālo peptīdu klātbūtni. Paaugstināta iekaisuma citokīnu un antibakteriālo peptīdu ekspresija tiek novērota audos ap biomateriālu pēc antibiotikas nesaturošu biomateriālu implantācijas un kontaminācijas ar baktēriju tīrkultūru.
\end{abstract}




\begin{abstract}
Nowaday, biomaterials are used more frequently and are becoming increasingly important as biomaterials are used in all medical fields, and often the use of biomaterials are of life saving importance.

Due to the extensive use and applications of biomaterials, and different types of biomaterials associated infections which are a significant medical problem. Depending on the type of infection, it may increase the patient's risk of mortality, and increase the total cost of treatment due to necessary replacement of biomaterial. To prevent infection of biomaterials, it is necessary to reduce bacterial adhesion and biofilm formation on the biomaterial. This can be achieved with the use of antimicrobial substances. Local antibiotic substances released from the biomaterial is an advantage compared with most systemic antibiotic which are given to the patients before and after implantation surgery.

The aim of this work is to exam the antibacterial efficiency of hydroxyapatite biomaterials with antibiotics (gentamicin or ciprofloxacin) and biodegradable polymer against the most common post-operative causative agents - Pseudomonas aeruginosa ( $P$. aeruginosa) and Staphylococcus epidermidis (S. epidermidis). This work also compares the antimicrobial properties of composite materials with biodegradable polymers and without biodegradable polymers. Antibacterial properties of biomaterials were investigated against S. epidermidis and $P$. aeruginosa by using a standardized disc diffusion method in an agar medium, and in the bacterial suspension.

The intensity of Inflammatory cytokines (TNF- $\alpha$ a IL-10) and antibacterial peptides ( $\beta$ defensīna-2) were tested in an in vivo study after a biomaterial sample implantation in the rabbits subcutaneous pocket and wound contamination with $S$. epidermidis or P. aeruginosa.

The results showed that the biomaterials with biodegradable polymer and antibiotic substances have statistically significantly longer antibacterial time than the biomaterials with antibiotic substances without the biodegradable polymer. The method which was used doesn't influence the antibacterial properties of biomaterials. The porosity level of biomaterials influences on antibacterial time, the biomaterials with lower porosity level have statistically significantly shorter antibacterial time than biomaterials with higher porosity levels.

In vivo study results showed that after composite material implantation with antibiotic substances, levels of inflammatory cytokines and antimicrobial peptides doesn't increase in the surrounding tissues around biomaterials. Increased levels inflammatory cytokines and antibacterial peptides are in the tissue around biomaterials, after an implantation of biomaterials without antibiotic substances.
\end{abstract}


DARBĀ LIETOTIE SAĪSINĀJUMI

\begin{tabular}{|c|c|c|}
\hline Saīsinājums & $\begin{array}{c}\text { Nosaukums } \\
\text { anglu / latīnu valodā }\end{array}$ & $\begin{array}{c}\text { Nosaukums } \\
\text { latviešu valodā }\end{array}$ \\
\hline AIDS & $\begin{array}{l}\text { acquired Immune Deficiency } \\
\text { Syndrome }\end{array}$ & iegūts imūndeficīta sindroms \\
\hline ASV & United States of America & Amerikas Savienotās Valstis \\
\hline B ly & B lymphocyte & B limfocìts \\
\hline BAI & biomaterial associated infections & biomateriālu saistītās infekcijas \\
\hline Bap & biofilm associated proteins & ar biofilmu asociētais proteīns \\
\hline $\mathrm{CD}$ & calcium deficient & kalcija deficits \\
\hline Cipro & ciprofloxacin & ciprofloksacīns \\
\hline DNS & deoxyribonucleic acid & dezoksiribonukleīnskābe \\
\hline eDNS & $\begin{array}{l}\text { extracelullar deoxyribonucleic } \\
\text { acid }\end{array}$ & ekstracelulāra dezoksiribonukleīnskābe \\
\hline ELISA & $\begin{array}{l}\text { enzyme-linked immunosorbent } \\
\text { assay }\end{array}$ & enzīmu saistošā imūnabsorbcijas metode \\
\hline Genta & gentamicin & gentamicīns \\
\hline HAp & hydroxyapatite & hidroksiapatìts \\
\hline IFN- $\gamma$ & interferon gamma & interferons gamma \\
\hline $\operatorname{IgA}$ & immunoglobulin A & imūnglobulīns $\mathrm{A}$ \\
\hline $\mathrm{IgG}$ & immunoglobulin $G$ & imūnglobulīns $\mathrm{G}$ \\
\hline IL-1 & interleukin-1 & interleikīns-1 \\
\hline IL-6 & interleukin-6 & interleikīns-6 \\
\hline IL-10 & interleukin-10 & interleikīns-10 \\
\hline IL-12 & interleukin-12 & interleikīns-12 \\
\hline KVV & colonies forming units (CFU) & kolonijas veidojošās vienības \\
\hline LPS & lipopolysaccharides & lipopolisaharīdi \\
\hline $\mathrm{MCH}$ II & $\begin{array}{l}\text { major histocompatibility } \\
\text { complex II }\end{array}$ & galvenais audu saderības komplekss II \\
\hline MIC & $\begin{array}{l}\text { minimum inhibitory } \\
\text { concentration }\end{array}$ & minimāli inhibējošā koncentrācija \\
\hline MRSA & $\begin{array}{l}\text { Methicillin-resistant } \\
\text { Staphylococcus aureus }\end{array}$ & $\begin{array}{l}\text { meticilīnrezistentais Staphylococcus } \\
\text { aureus }\end{array}$ \\
\hline MRSE & $\begin{array}{l}\text { Methicillin-resistant } \\
\text { Staphylococcus epidermidis }\end{array}$ & $\begin{array}{l}\text { meticilīnrezistentais Staphylococcus } \\
\text { epidermidis }\end{array}$ \\
\hline NK & natural killer cells & dabīgās galētājšūnas \\
\hline PBP & penicillin binding proteins & penicilīnu saistošais proteīns \\
\hline PBS & phosphate-buffered saline & fosfāta buferšksīidums \\
\hline PCL & polycaprolactone & polikaprolaktons \\
\hline PGA & polyglycolide & poliglikolīds \\
\hline PHB & polyhydroxybutyrate & polihidroksibutirāts \\
\hline PIA & $\begin{array}{l}\text { intercellular polysaccharide } \\
\text { adhesin }\end{array}$ & intercelulārais polisaharīda adhezīns \\
\hline PLGA & polylactic-co-glycolic acid & polipien-ko-glikolskābe \\
\hline PLLA & polylactic acid & polipienskābe \\
\hline RNS & ribonucleic acid & ribonukleīnskābe \\
\hline SEM & scanning electron microscope & skenējošā elektronmikroskopija \\
\hline Spp. & multiple species & vairākas sugas \\
\hline
\end{tabular}




\begin{tabular}{|l|l|l|}
\hline TCP & tricalcium phosphate & trikalcija fosfāts \\
\hline $\mathrm{Th}_{1}$ & T helper cells subopulation 1 & T palīgšūnas subpopulācija-1 \\
\hline $\mathrm{Th}_{2}$ & Thelper cells subopulation 2 & T palīgšūnas subpopulācija-2 \\
\hline TNF- $\alpha$ & tumor necrosis factor & tumora nekrozes faktors \\
\hline TSA & trypticase soy agar & triptikāzes sojas agars \\
\hline TSB & trypticase soy broth & triptikāzes sojas buljons \\
\hline UV & ultraviolet & ultravioletais starojums \\
\hline
\end{tabular}




\section{IEVADS}

Biomateriāli tiek izmantoti visās medicīnas nozarēs, lai aizvietotu cilvēka orgānus vai orgānu daļas, tādējādi uzlabojot pacientu dzīves kvalitāti un paildzinot dzīvildzi. Ortopēdijā biomateriālus izmanto, lai aizvietotu locītavas vai kaulus un to daļas, stomatoloǵijā - kā zobu implantus, kardiolog̣ijā - kā mākslīgos sirds vārstuḷus vai kardiostimulatorus. Visās medicīnas nozarēs ļoti plaši tiek izmantoti tādi biomedicīniskie implantāti kā intravenozie katetri, urīnpūšla katetri, intubācijas aprīkojums un citi biomateriālu veidotie medicīniskie aprīkojumi. Šo uzskaiti var turpināt ilgi un plaši, kas tikai apstiprina biomateriālu būtisko nozīmi mūsdienās (Huebsch et al., 2009).

Ar biomateriālu izmantošanu diemžēl samērā bieži ir saistītas dažādas komplikācijas, un viena no tām ir bakteriāli ierosinātas BAI. Lai gan pirms un pēc biomateriālu implantācijas operācijām tiek veikti profilakses pasākumi, nodrošinot operāciju sterilitāti, kā arī citi profilaktiski pasākumi, lai samazinātu BAI risku un infekcijas attīstības plašumu. Kaut arī ortopēdisko implantātu infekciju attīstības risks ir tikai 1-3\%, šo infekciju rezultātā pacientu letalitātes risks ir augsts (Darouiche et al., 2001), kā arī palielinās kopējās ārstniecības izmaksas, kas saistīts ar ortopēdiskā implantāta aizvietošanu un ilgāku hospitalizācijas laiku (Haenle et al., 2012).

BAI ir lokāla infekcija, kas var rasties pēc bakteriālas kontaminācijas operācijas laikā, pēcoperācijas periodā vai hematogēnas diseminācijas veidā no kāda cita cilvēka organisma infekcijas perēkḷa. N̦emot vērā lokālās infekcijas īpatnības, efektīvākā BAI profilakse ir ar antibiotiskajām vielām apstrādātu biomateriālu lietošana, lai mazinātu bakteriālo adhēziju pie biomateriāliem un biofilmu veidošanos (van de Belt et al., 2001).

Lai mazinātu BAI infekcijas risku, lokālai antibiotisko vielu izdalei no biomateriāla ir virkne priekšrocību, salīdzinot ar sistēmisku antibiotisko vielu lietošanu. Lokālā antibiotisko vielu izdale no biomateriāla ļauj samazināt blakusparādību rašanās risku, kas rodas, sistēmiski lietojot antibiotiskās vielas (Campoccia et al., 2010). Biežākās no šīm blakusparādībām ir alerğiskas reakcijas, toksicitāte un disbakteriozes.

Lietojot kompozītmateriālus ar antibiotiskajām vielām un to savienojumu ar bionoārdāmu polimēru, tiek panākta antibiotisko vielu vadāma, kontrolēta un ilglaicīga izdale, kas paildzina biomateriāla antibakteriālās īpašības (Leprêtre et al., 2009).

Biomateriāla virsmai jāspēj ne tikai samazināt BAI risku, bet tai ir jābūt arī biosaderīgai ar apkārtējiem cilvēka audiem. To gan nosaka biomateriāla izmantošanas mērķis, jo neatkarīgi no biomateriāla sintēzes veida un pielietojuma tas tomēr cilvēka organismam ir svešksermenis (Franz et al., 2011). 


\section{Darba mērksis}

In vitro un in vivo pētījumā noskaidrot, kāda kompozịtmateriāliem ar antibiotiskajām vielām un ar biodegradējamu polimēru ir antibakteriālā efektivitāte pret biežākajiem pēcoperācijas infekciju ierosinātājiem - P. aeruginosa un S. epidermidis.

\section{Darba hipotēzes}

1. Kompozītmateriāli ar biodegradējamu polimēru un antibiotiskajām vielām var būtiski samazināt pēcoperācijas infekcijas risku pēc implantātu izmantošanas.

2. Kompozītmateriāli ar biodegradējamu polimēru un antibiotiskām vielām var būtiskāk ietekmēt antibakteriālās īpašības, salīdzinot ar tādiem pašiem biomateriāliem bez polimēra pārklājuma.

3. PLLA un PCL atšksirīgi ietekmē kompozītmateriālu ar biodegradējamu polimēru un antibiotiskajām vielām antibakteriālo efektivitāti pret $S$. epidermidis un $P$. aeruginosa.

4. Iekaisuma citokīnu un antibakteriālo peptīdu ekspresija audos ap biomateriālu ir intensīvāka, implantējot antibiotiskās vielas nesaturošu biomateriālu.

\section{Darba uzdevumi}

1. Izvērtēt dažādu kompozītmateriālu antibakteriālo efektivitāti pret P. aeruginosa un S. epidermidis in vitro.

2. Pētīt, kā biodegradējamais polimērs ietekmē biomateriālu antibakteriālo efektivitāti in vitro.

3. Salīdzināt PCL un PLLA ietekmi uz biomateriālu antibakteriālās darbības laiku.

4. Noteikt kompozītmateriālu ietekmi uz iekaisuma citokīna IL-10 un TNF- $\alpha$ un antibakteriālā peptīda $\beta$-defensīna-2 ekspresiju in vivo.

5. Izvērtēt kompozītmateriālu porainības līmeņa ietekmi uz biomateriālu antibakteriālās darbības laiku.

\section{Darba novitāte}

Darbā pētītie biomateriāli ir Latvijā oriǵināli sintezēti pēc jaunākajām un līdz šim neizmantotām metodēm. Pirmo reizi tiek detalizēti pētīta šāda veida biomateriālu antibakteriālā darbība in vitro un to biosaderība in vivo, nosakot iekaisuma citokīnus un antibakteriālos peptīdus. Biosaderība pētīta, izmantojot ELISA metodi. Metode iekaisuma procesa izvērtēšanai apkārtējos audos tieši pēc biomateriāla implantācijas Latvijā tiek izmantota pirmo reizi. 


\section{Materiāli tehniskais nodrošinājums}

Rīgas Stradiṇa universitātes Bioloǵijas un mikrobioloǵijas katedra nodrošināja pētījuma in vitro realizāciju, kā arī ELISA komplektus pētījumam in vivo. Pētījums in vivo tika veikts Rīgas Stradiṇa universitātes eksperimenta dzīvnieku audzētavā. Pētītie biomateriāli tika oriǵināli sintezēti Rīgas Tehniskās universitātes Rūdolfa Cimdiṇa Rīgas biomateriālu inovāciju un attīstības centrā.

\section{Darba ētiskie aspekti}

Pētījumam in vivo tika saņemta atļauja no Valsts Pārtikas un veterinārā dienesta, atļaujas Nr. 24 (sk. pielikumā).

\section{Personīgais ieguldījums}

Autors pats ir veicis visus in vitro un in vivo pētījumus, patstāvīgi veicis ķirurǵiskās operācijas eksperimentālajiem dzīvniekiem, audu paraugu savākšanu un izmeklēšanu, izmantojot molekulārās diagnostikas metodes.

\section{Darba struktūra}

Zinātniskais darbs uzrakstîts uz 106 lapaspusēm, ietver šādas nodaļas: ievads, literatūras apskats, materiāls un metodes, rezultāti, diskusija, secinājumi, literatūras saraksts, pielikumi. Darbā iekḷautas 9 tabulas un 69 attēli. Izmantoti 210 literatūras avoti. 


\section{LITERATŪRAS APSKATS}

\subsection{Antibiotisko vielu vēsture, pielietojums un antibakteriālā rezistence}

Antibiotiskās vielas ir medikamenti, kas tiek lietoti mikrobu nonāvēšanai (baktericīda darbība) vai to augšanas nomākšanai (bakteriostatiska darbība). Šobrīd ir zināmas aptuveni 15 antibiotisko vielu klases, un joprojām notiek aktīva jaunu antibiotisko vielu meklēšana un atklāšana. Savstarpēji antibiotiskās vielas atšķiras ar ķīmisko struktūru, darbības spektra plašumu, kā arī darbības mehānismu un veidu, kā tās ietekmē baktērijas (baktericīdi vai bakteriostatiski). Baktericīda darbība ir antibiotisko vielu spēja nonāvēt baktēriju, bet bakteriostatiska darbība ir antibiotisko vielu spēja inhibēt baktēriju augšanu (Aminov, 2010).

Ar Aleksandra Fleminga atklājumu 1928. gadā, kad vinš̌ novēroja Staphylococcus aureus augšanas inhibīciju ap Penicillium notatum pelējuma sēnīti (Fleming, 1929), aizsākās mūsdienu antibiotisko vielu vēsture. Zināms, ka jau sen pirms "antibiotisko vielu ēras" aizsākuma 20. gs, sākumā senie grieķi, ēgiptieši un ķīnieši veidoja augu maisījumus, apstrādājot inficētas brūces. Tādējādi cilvēki jau vairāk nekā pirms diviem gadu tūkstošiem centās iegūt antiseptiskus līdzekḷus, kas mazinātu infekciju attīstības iespēju (Clardy et al., 2009). Veselus divpadsmit gadus Flemings neveiksmīgi centās pievērst zinātnieku uzmanību Penicillium notatum antibakteriālajām īpašībām, līdz 1940. gadā divi Oksfordas universitātes zinātnieki - Hovards Florejs (Howard Walter Florey) un Ernests Čeins (Ernest Boris Chain) - neatkarīgi no Fleminga pētījumiem prezentēja savu darbu par penicilīna antibakteriālajām īpašībām (Chain et al., 1940). 1945. gadā par saviem atklājumiem visi trīs zinātnieki saņēma Nobela prēmiju fiziologijāā un medicīnā (Ligon, 2004).

Antibiotisko vielu atklāšana turpinājās, un 1943. gadā, mikrobiologs Selmans Vaksmans (Selman Waksman) atklāja aminoglikozīdu klases antibiotisko vielu pārstāvi streptomicīnu, kas vēlāk tika lietots tuberkulozes ārstēšanā. Sterptomicīns tika ļoti plaši lietots, bet tam piemita daudz blakusparādību (Waksman et al., 1942). Vēl pēc divpadsmit gadiem Amerikas Savienotajās Valstīs Loids Konovers (Lloyd Conover) sintezēja plaša darbības spektra sintētisko antibiotisko vielu tetraciklīnu. Līdz tetraciklīnu spēja sintezēt laboratorijāâ, pagāja aptuveni desmit gadi kopš tā izdalīšanas no Actynomices (Chopra et al., 2001). Arī turpmākajos gados turpinājās pētījumi antibiotisko vielu nozarē, un tika iegūtas jaunas antibiotisko vielu klases, kas bija neaizvietojams medicīnas nozares ieguvums daudzu pacientu dzīvības glābšanā (Aminov, 2010). 
Antibiotiskajām vielām izšksir trīs galvenos darbības mehānismus: tie inhibē 1) baktēriju nukleīnskābju (DNS vai RNS) replikāciju vai sintēzi, 2) proteīnu sintēzi baktērijās un 3) baktēriju šūnas sienas sintēzi (Kohanski et al., 2010).

Aizvien plašāk, biežāk un dažkārt nevajadzīgi lietojot antibiotiskās vielas, attīstās baktēriju rezistence pret antibiotiskajām vielām, kas ir nozīmīga problēma medicīnas nozarē, ārstējot infekcijas slimības. Eiropā katru gadu aptuveni 25 tūkstoši pacientu nomirst multirezistento baktēriju infekciju dēl (Aminov, 2009).

Galvenie faktori, kas ietekmē baktēriju rezistences veidošanos pret antibiotiskajām vielām, ir antibiotisko vielu dažādais klāsts un plašais spektrs, kas, terapijā nesamērīgi izmantojot antibiotiskās vielas, izraisa arvien plašāku baktēriju rezistenci. Tāpēc, lai samazinātu baktēriju rezistences attīstību pret antibiotiskajām vielām, ir ļoti svarīgi pacientam izrakstīt pēc darbības spektra visatbilstošākās antibiotiskās vielas, izvēloties optimālo devu un ievades veidu, un nepieciešamības gadījumos pirms antibakteriālās terapijas sākšanas veikt antibiotisko vielu jutības testus un slimības ierosinātāja identifikāciju (Caron et al., 2010).

\subsection{Kvinoloni}

Kvinoloni kā antibiotiskās vielas tika atklāti 1962. gadā, un kopš tā laika kvinolonu klasei izšķirir četras paaudzes (Lesher et al., 1962). Pie pirmās paaudzes kvinoloniem pieder nalidiksicīnskābe, ko biežāk izmanto urīnceļu infekciju gadījumā. Galvenais darbības spektrs ir gramnegatīvās baktērijas, izņemot $P$. aeruginosa. Otrās paaudzes kvinoloniem ir antibakteriālā aktivitāte pret $P$. aeruginosa, un ne tikai pret gramnegatīvajām baktērijām, bet arī pret grampozitīvām baktērijām, piemēram, S. epidermidis. Otrās paaudzes kvinolonus var izmantot pret atipisko baktēriju ierosinātām saslimšanām, tādām kā Mycoplasma spp., Legionella pneumonia u. c. Pie otrās paaudzes kvinoloniem pieder ciprofloksacīns, norfloksacīns, lomefloksacīns u. c. Otrās paaudzes kvinoloniem ir maza aktivitāte pret Streptococcus pneumoniae, bet trešās paaudzes kvinoloniem ir lielāka aktivitāte pret šo ierosinātāju, tāpēc levofloksacīnu rekomendē sadzīvē iegūto pneimoniju ārstēšanā. Trijām pirmajām kvinolonu paaudzēm nav antibakteriālās aktivitātes pret anaerobām baktērijām, taču ceturtās paaudzes fluorhinoloniem ir plaša spektra aktivitāte pret anaerobām baktērijām un rezistentajām baktērijām (King et al., 2000). 


\subsubsection{Ciprofloksacīna pielietojums}

Ciprofloksacīns pieder pie otrās paaudzes kvinoloniem, un to no šīs paaudzes antibiotiskajām vielām klīnikās lieto visbiežāk (Oliphant et al., 2002). Ciprofloksacīna ķīmiskā formula ir $\mathrm{C}_{17} \mathrm{H}_{18} \mathrm{FN}_{3} \mathrm{O}_{3}$ (1.1. attēls). To var lietot perorāli vai intravenozi pieaugušajiem tādu bakteriālo slimību ārstēšanā kā urīnceļu infekcijas (uretrīts, cistīts, pielonefrīts), hronisks bakteriāls prostatîts (Nabera et al., 2000), akūts sinusīts, apakšējo elpošanas ceḷu infekcijas (pneimonija, bronhīts, traheobronhīts), izṇemot gadījumus, kad augšējo elpošanas ceḷu infekcijas ierosinātājs ir S. pneumoniae (Low, 2005), ādas infekcijas (celulīts, folikulīts), kaulu vai saišu infekcijas (septisks artrīts, osteomielīts), intraabdominālas infekcijas (peritonīts, holecistīts, holangīts u. c.), infekciozā diareja (Solomkin et al., 2010) u. c. infekcijas, ko izraisa gramnegatīiās un grampozitīvās aerobās baktērijas.

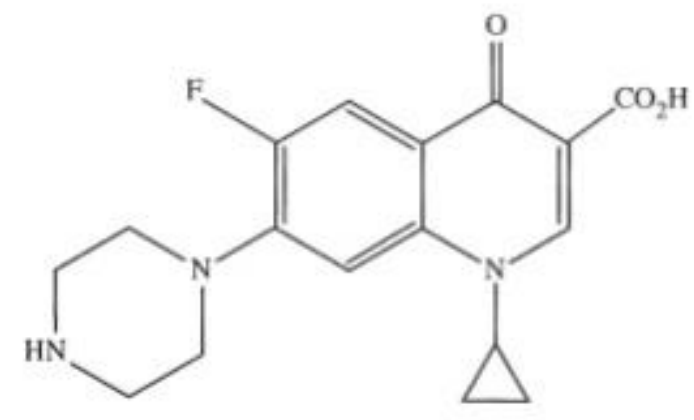

1.1. attēls. Ciprofloksacīna ķīmiskā struktūra

(Ball, 2000)

\subsubsection{Ciprofloksacīna darbības mehānisms}

Ciprofloksacīnam piemīt baktericīda iedarbība, un tās pamatā ir spēja inhibēt DNS sintēzi baktērijās, inhibējot divus DNS topoizomerāžu klases enzīmus - DNS girāzi un topoizomerāzi IV. Šiem enzīmiem ir svarīga loma baktērijas DNS replikācijas, transkripcijas un rekombinēšanas procesos. DNS žirāze ir tetramērs, kas sastāv no 2 GyrA un 2 GyrB apakšvien̄ibām. Topoizomerāze IV sastāv no 2 ParC un 2 ParE apakšvienībām. DNS girāze un topoizomerāze IV ir strukturāli līdzīgas, jo ParC ir homologs GyrA, un ParE ir homologs GyrB. Topoizomerāze IV darbojas DNS replikācijas beigu fāzē, nodrošinot meithromosomu atdalīšanos. Ciprofloksacīns inhibē šos enzīmus, stabilizējot DNS-girāzes kompleksu vai DNS-topoizomērāzes IV kompleksu. Šie stabilizētie kompleksi bloksē turpmāko DNS replikāciju, un baktērijas strauji aiziet bojā. (Hooper et al., 1987; LeBel, 1988). 


\subsubsection{Ciprofloksacīna darbības spektrs}

Starp visiem kvinoloniem ciprofloksacīns vislabāk darbojas pret gramnegatīvajām baktērijām, un to iesaka kā labāko antibakteriālo līdzekli pret $P$. aeruginosa ierosinātām saslimšanām. Ciprofloksacīnu izmanto pret tādiem gramnegatīvajiem ierosinātājiem kā Escherichia coli (E. coli), Haemophilus influenzae, Klebsiella pneumoniae, Campylobacter jejuni, Proteus spp., Shigella spp., Neisseria gonorrhoeae un citas. Ciprofloksacīna darbības spektrs pret grampozitīvām baktērijām ir mazāks un tā aktivitāte ir zemāka nekā pret gramnegatīvajām baktērijām (Campoli-Richards et al., 1988). Nozīmīgākie grampozitīvie ierosinātaji, pret kuriem izmanto ciprofloksacīnu, ir $S$. aureus, S. epidermidis un Streptococcus spp. (Wolfson et al., 1985). Pret anaerobām baktērijām ciprofloksacīns netiek izmantots, jo tikai 31\% anaerobo baktēriju ir jutīgas pret ciproflokacīnu, kas ir mazāk, nekā izmantojot citu antibiotisko vielu grupu līdzekli (Sutter et al., 1985). Ciprofloksacīns tiek rekomendēts pieaugušajiem kaulu un saišu infekciju gadījumā. Osteomielītu ierosina virkne gramnegatīvu baktēriju, piemēram, Klebsiella pneumoniae, Proteus mirabilis, P. aeruginosa, kā arī grampozitīvas baktērijas - Staphylococcus aureus, S. epidermidis un citi koagulāzes negatīvie stafilokoki (MacGregor et al., 1990).

Aptuveni 3\% no visiem infekciozā endokardīta gadījumiem ierosina HACEK grupas mikroorganismi (Haemophilus spp., Aggregatibacter actinomycetemcomitans, Cardiobacterium hominis, Eikenella spp., Kingella spp.), kas ir gramnegatīvās baktērijas. Visas šīs baktērijas ir cilvēka normālās mikrofloras pārstāvji (Das et al., 1997). N̦emot vērā ciprofloksacīna efektivitāti pret gramnegatīvām baktērijām, to iesaka kā alternatīvu antibiotisko vielu dabīgo un protēžu vārstuļu infekciju terapijā (Gould et al., 2012).

\subsubsection{Ciprofloksacīna farmakokinētika un termostabilitāte}

Ciprofloksacīns metabolizējas nierēs un dạ̧ēji arī aknās par vismaz četriem metabolītiem - 2-aminoetilamino (M1), sulfociprofloksacīnu (M2), oksociprofloksacīnu (M3) un N-formilciprofloksacīnu (M4). Šo metabolītu aktivitāte ir mazāka par ciprofloksacīna aktivitāti, taču varētu būt līdzīga citām kvinolonu grupas antibiotikām (M3 un M4 darbība ir salīdzināma ar norfloksacīna darbību) (Vance-Bryan et al., 1990, Landersdorfer et al., 2010). Ciprofloksacīns un tā metabolīti tiek ekskretēti ar urīnu un fēcēm. Nemetabolizētais ciprofloksacīns (66\%) tiek ekskretēts ar urīnu, pateicoties glomerulārajai filtrācijai un tubulārajai sekrēcijai. 
Maksimālā ciprofloksacīna koncentrācija serumā tiek sasniegta pēc 1-2 stundām, tam uzsūcoties gastrointestinālajā traktā. Lietojot ciprofloksacīnu perorāli $250 \mathrm{mg}, 500 \mathrm{mg}$ vai 750 mg devā pieaugušajiem ar normālu nieru funkciju, vidējā koncentrācija serumā ir $0,1 \mu \mathrm{g} / \mathrm{ml}$, $0,2 \mu \mathrm{g} / \mathrm{ml}$ un 0,4 $\mu \mathrm{g} / \mathrm{ml}$ (Payen et al., 2003).

Pieaugušajam ar normālu nieru funkciju ciprofloksacīna pussabrukšanas periods ir vidēji 4 stundas. 10-15\% ciprofloksacīna tiek ekskretēts neizmainīts ar urīnu un 10-15\% - kā metabolīti 24 stundu laikā. 40\% ciprofloksacīna neizmainītā un metabolizētā veidā tiek ekskretēti ar fēcēm 5 dienu laikā. Liela dạ̧a neizmainītā ciprofloksacīna, izdaloties žultij, parādās fēcēs. Ciprofloksacīns aktīvā formā ir konstatēts siekalās, deguna un bronhu sekrētā, gḷotādās, limfā, peritoneālajā šķidrumā, žultī, plaušās, ādā, taukaudos, muskuḷos, kaulos, dal̦ēji arī dzimumorgānos, īpaši prostatas sekrētā. Nenozīmīgi maza ciprofloksacīna koncentrācija spēj difundēt cerebrospinālajā šķidrumā (LeBel et al., 1988). Tiek rekomendēts ciprofloksacīnu glabāt $18-29{ }^{\circ} \mathrm{C}$ temperatūrā un nepieļaut tiešu UV staru iedarbību (Eisenhart et al., 2012). Ciprofloksacīna koncentrācija dažādās temperatūrās ir atšķkirīga (1.1. tabula).

1.1. tabula

Ciprofloksacīna šşīduma $(25 \mathrm{mg} / \mathrm{mL})$ koncentrācijas izmaiṇas laikā atkarībā no temperatūras izmaiṇām (Eisenhart et al., 2012)

\begin{tabular}{|l|l|l|l|c|}
\hline \multirow{2}{*}{$\begin{array}{l}\text { Laiks } \\
\text { (stundas) }\end{array}$} & \multicolumn{4}{|c|}{ Temperatūra $\left({ }^{\circ} \mathrm{C}\right)$} \\
\cline { 2 - 5 } & \multicolumn{1}{|c|}{52} & \multicolumn{1}{c|}{71} & 93 \\
\hline 1 & $19,55 \mathrm{mg} / \mathrm{mL}$ & N/A & $22,64 \mathrm{mg} / \mathrm{mL}$ & $23,75 \mathrm{mg} / \mathrm{mL}$ \\
\hline 4 & $22,09 \mathrm{mg} / \mathrm{mL}$ & $24,40 \mathrm{mg} / \mathrm{mL}$ & $11,84 \mathrm{mg} / \mathrm{mL}$ & $20,97 \mathrm{mg} / \mathrm{mL}$ \\
\hline 16 & $10,84 \mathrm{mg} / \mathrm{mL}$ & $23,90 \mathrm{mg} / \mathrm{mL}$ & N/A & $2,74 \mathrm{mg} / \mathrm{mL}$ \\
\hline
\end{tabular}

\subsubsection{Baktēriju rezistences mehānismi pret ciprofloksacīnu}

Baktēriju rezistence pret antibiotiskām vielām, ieskaitot fluorhinolonus, ir izplatîta problēma antibakteriālajā terapijā. Kopš pirmās paaudzes fluorhinolonu lietošanas 1962. gadā tiek novērota baktēriju rezistence pret šīs klases antibiotiskajām vielām. Baktēriju rezistence pret ciprofloksacīnu attīstās mutāciju rezultātā, kas skar gyrA un parC gēnus. Gramnegatīvajām baktērijām biežāk rezistence attīstās izmainītas DNS girāzes, bet grampozitīvajām baktērijām - izmainītas topoizomerāzes IV enzīmu gēnos. Bez šiem rezistences mehānismiem baktērijām novēro arī effluksa sūkṇa rezistences mehānismu (Fantin et al., 2009). Daudzas baktērijas rezistenci pret antibiotiskajām vielām iegūst ar Qnr plazmīdu palīdzību (Poirel et al., 2005). Pēc ASV slimnīcās veiktajiem pētījumiem, pret ciprofloksacīnu biežāk rezistence tiek novērota baktērijām, kurām jau ir rezistence pret citu grupu antibiotiskajām vielām, piemēram, 90\% MRSA baktēriju tiek novērota rezistence pret 
ciprofloksacīnu. Rezistentajām Actinetobacter baumanii 60\% gadījumu tiek novērota rezistence pret ciproflksacīnu. Gandrīz vai visiem (98\%) vankomicīna rezistentajiem Enterococcus tiek novērota rezistence pret ciprofloksacīnu. Savukārt tikai 25\% P. aeruginosa gadījumu tiek novērota rezistence pret ciprofloksacīnu (Jacoby, 2005; Dalhoff, 2012). Starp visiem urīnceḷu infekciju gadījumiem, ko ierosina $P$. aeruginosa, 58,8\% gadījumu baktērijas bija rezistentas pret ciprofloksacinu (Mandal et al., 2012).

\subsubsection{Ciprofloksacīna ierosinātās blakusparādības}

Ciprofloksacīns ir antibiotiska viela, kurai piemīt plaša spektra un efektīvs darbības mehānisms, bet atsevišksiem pacientiem bez vēlamā efekta ir novērojamas arī nevēlamas blakusparādības. Viena no galvenajām blakusparādībām, kas raksturīga ciprofloksacīna terapijai, ir cīpslu iekaisumi un plīsumi (Kim et al., 2010). Paaugstināts cīpslu plīsuma risks ir pacientiem pēc 60 gadu vecuma, kuri lieto kortikosteroīdu preparātus, kā arī pacientiem pēc orgānu transplantācijas operācijām. Visbiežāk šî ciprofloksacīna lietošanas komplikācija skar Ahileja cīpslu (Yu et al., 2005).

Lietojot ciprofloksacīnu antibakteriālajā terapijā, nevēlamas blakusparādības tiek novērotas 5-14\% pacientu. Šo blakusparādību dēl̦ 1,0\% pacientu tiek atcelta ciprofloksacīna lietošana, nomainot to pret citu antibiotisko vielu. Parasti 2,1 līidz 5,5\% pacientu, lietojot ciprofloksacīnu, ir slikta dūša un vemšana. Līdz 2,1\% pacientu pēc ciprofloksacīna lietošanas ir diareja, bet izsutumi uz ādas ir 1,6\% pacientu. Tādas centrālās un perifērās nervu sistēmas blakusparādības kā galvas reiboṇi un sāpes tiek novērotas 0,4 līdz 1,5\% pacientu pēc ciprofloksacīna lietošanas.

Salīdzinot ar citu paaudžu fluorhinoloniem, pēc ciprofloksacīna lietošanas blakusparādības pacientiem novēro retāk (Wilton et al., 1996).

\subsection{Aminoglikozīdi}

Mēginot atklāt antibiotiskās vielas, kuras būtu līdzīgas penicilīnam, no Streptomyces griseus tika izdalīts pirmais aminoglikozīdu pārstāvis streptomicīns, kuru joprojām izmanto tuberkulozes ārstēšanā (Waksman et al, 1944). Vairākus gadus vēlāk no Streptomyces spp. tika izdalītas arī citas antibiotiskās vielas, kuras pieder pie aminoglikozīdu klases, piemēram, neomicīns tika izdalīts no Streptomyces fradiae un kanamicīns - no Streptomyces kanamyceticus (Waksman et al., 1949; Umezawa et al., 1957). Kā viens no pēdējiem aminoglikozīdu klases pārstāvjiem tika izdalīts tobramicīns no Streptomyces tenebrarius 
(Higgins et al., 1967). Aminoglikozīdi ir plaša spektra antibiotiskās vielas, ko galvenokārt lieto gramnegatīvu baktēriju ierosinātu saslimšanu ārstēšanā, bet aminoglikozīdi ir efektīvi arī pret grampozitīvām baktērijām (Moore et al., 1987).

\subsubsection{Gentamicīns}

Gentamicīns ir antibiotiskā viela, kas pieder pie aminoglikozīdu klases. Tā ķīmiskā formula ir $\mathrm{C}_{21} \mathrm{H}_{43} \mathrm{~N}_{5} \mathrm{O}_{7}$ (1.2. attēls). To izdalīja 1963. gadā no Micromonosporum purpurea. Gentamicīnam ir plašs darbības spektrs, un to galvenokārt lieto aerobo gramnegatīvo baktēriju (P. aeruginosa, Proteus spp., Serratia spp. u. c.) ierosinātu infekciju antibakteriālā terapijā. Gentamicīnu lieto arī grampozitīvo Staphylococcus spp. izraisītu infekciju gadījumā (Weinstein et al., 1963). Gentamicīns sastāv no trīs pamatvienībām: C1, C1a, C2, kā arī citām mazākām daḷām. Starp dažādiem gentamicīna preparātiem pastāv šo subvienību variācijas, ko nosaka konkrētā preparāta ražotājs (Isoherranen et al., 2000).

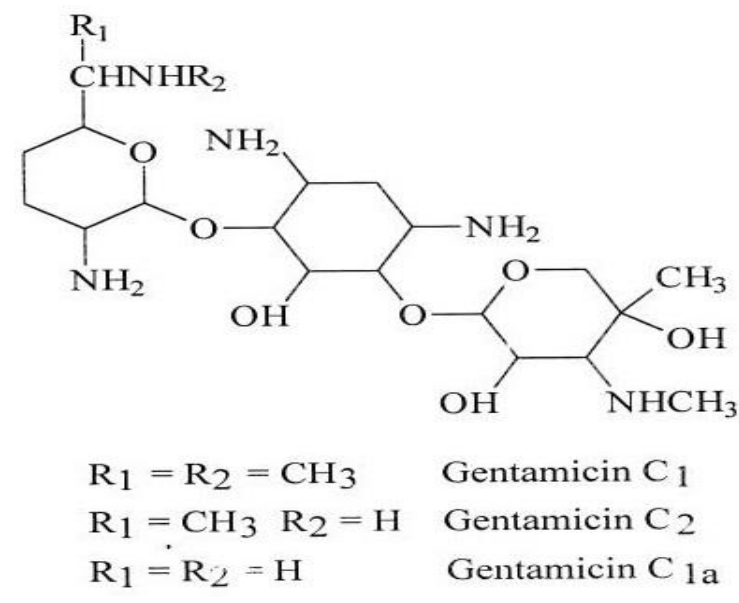

\section{2. attēls. Gentamicīna ķīmiskā struktūra}

(Isoherranen et al., 2000)

\subsubsection{Gentamicīna darbības mehānisms}

Gentamicīna baktericīdās darbības pamatā ir neatgriezeniska saistīšanās ar baktērijas ribosomām, tādējādi inhibējot proteīnu sintēzi. Ir noskaidrots, ka baktēriju ribosomu 30S subvienība sastāv no 16S RNS un ribonukleotīdu kompleksa, kura galvenā funkcija tiek realizēta mRNS translācijas laikā. Piesaistoties pie $16 \mathrm{~S}$ rRNS gentamicīns veido stabilu kompleksu, kas noved pie kodona-antikodona nesakritības, un rezultātā šūna producē defektīvus proteīnus, kas ir šūnas nāves iemesls (Lambert, 2012). 


\subsubsection{Gentamicīna pielietojums}

Gentamicīnu lieto E. coli, P. aeruginosa un citu gramnegatīvu baktēriju ierosinātu urīnceļu infekciju gadījumā. Kombinācijā ar beta laktāmu antibiotiskajām vielām gentamicīnu lieto gramnegatīvu baktēriju izraisītas sepses gadījumā, ko visbiežāk ierosina $P$. aeruginosa. Gentamicīnu iesaka lietot pret antibiotiskām vielām rezistentu ierosinātāju gadījumā, visbiežāk pret $P$. aeruginosa, Klebsiella spp., Acinetobacter baumanii (Leibovici et al., 2009).

Staphylococcus spp. un beta hemolītisko Streptococcus spp. ierosināta bakteriāla endokardīta gadījuma kā antibakteriālais līdzeklis tiek nozīmēts gentamicīns. N̦emot vērā, ka šīm baktērijām pastāv rezistences iespējamība pret gentamicīnu, to nozīmē kopā ar beta laktāma antibiotiskām vielām, piemēram, penicilīnu (Graham et al., 2002).

\subsubsection{Gentamicīna farmakokinētika}

Gentamicīna terapijas laikā tas strauji uzsūcas parenterāli un pēc 30-90 minūtēm sasniedz maksimālo koncentrāciju serumā. Pieaugušam cilvēkam ar normālu nieru funkciju gentamicīna pussabrukšanas laiks ir 2-3 stundas, tas tiek ekskretēts caur nieru glomerulāro filtrāciju nemodificētā veidā proporcionāli tā koncentrācijai serumā. Gentamicīna eliminācija ir atkarīga no nieru funkcijas, respektīvi, seruma kreatinīna koncentrācijas, glomerulārās filtrācijas ātruma un kreatinīna klīrensa (Tam et al., 2006; Lazebnik et al., 1985).

\subsubsection{Gentamicīna lietošanas blakusparādības}

Galvenās toksiskās īpašības, kas piemīt gentamicīnam, ir ototoksicitāte, neirotoksicitāte un nefrotoksicitāte. Blakusparādības skar pacientus ar nieru mazspēju, cistisko fibrozi un gados vecākus pacientus, kuriem nozīmētas lielas gentamicīna devas (Smyth et al., 2010). Līdzsvara un dzirdes traucējumi gentamicīna lietošanas laikā ir tādēḷ, ka tas skar VIII kraniālo nervu. Gentamicīna antibakteriālās terapijas laikā $47 \%$ pacientu attīstās līdzsvara traucējumi, bet 38\% - tikai līdzsvara traucējumi. Smagākos gadījumos pēc antibakteriālās terapijas beigām vai atcelšanas gadījumā var attīstīties daḷējs vai piln̄̄gs neatgriezenisks kurlums. Dzirdes traucējumus novēro 3\% pacientu (Ahmed et al., 2012). Pēc gentamicīna lietošanas aptuveni 17-33\% pacientu ar ototoksicitāti ir konstatēta genētiska predispozīcija ototoksicitātei. Aminoglikozīidu ototoksicitātes predispozīcija ir saistīta ar mitohondriālo DNS. Eiropā šīs predispozīcijas incidence ir $1: 500$ (Huth et al., 2011). Tāpat pie gentamicīna blakusparādībām ir pieskaitāmi arī nieru darbības traucējumi, kas attīstās 42\% pacientu 
(Ahmed et al., 2012). Gentamicīnam akumulējoties nieru proskimālajos, distālajos un savācējkanāliņos, var attīstīties proteinūrija, albuminūrija un smagākos gadījumos - tubulārā nekroze (Mingeot-Leclercq et al., 1999).

\subsubsection{Baktēriju rezistences mehānismi pret gentamicīnu}

Plašā gentamicīna izmantošanas iespēja bakteriālo infekciju terapijā ir novedusi pie pieaugošas baktēriju rezistences pret šo antibiotisko vielu. Biežākais baktēriju rezistences mehānisms pret gentamicīnu un citiem aminoglikozīdiem ir saistīts ar antibiotisko vielu enzīmu modifikāciju. Gentamicīna gadījumā to nodrošina trīs baktērijas enzīmi: aminoglikozīdu acetiltransferāze, aminoglikozīdu fosfotransferāze un aminoglikozīdu nukleotīdtransferāze. Šo enzīmu ietekmē gentamicīna darbība tiek nomākta un tas zaudē spēju saistīties ar baktēriju ribosomām (Green et al., 2013). P. aeruginosa šī rezistence var būt kodēta plazmīdu vai hromosomālā līmen̄i (Poole, 2005). Hromosomāli kodēts ir baktēriju rezistences mehānisms, kad izmainās šūnas membrānas permabilitāte un tādējādi antibiotiskā viela nenonāk šūnā (Mingeot-Leclercq et al., 1999). Pie galvenajiem baktēriju rezistences mehānismiem pret gentamicīnu ir pieskaitāms effluksa sūkņa mehānisms (Aires et al., 1999). Saskaņā Indijas apdegumu nodaļas pētījuma datiem biežāk rezistentie mikroorganismi pret gentamicīnu ir P. aeruginosa. Apdegumu pacientiem, kuriem P. aeruginosa tika izolēta no apdeguma brūces, 81,03\% gadījumu baktērija bija rezistenta pret gentamicīnu (Biswal et al., 2014). Apmēram 9\% gadījumu $P$. aeruginosa bija rezistentas pret gentamicīnu, kas tika izdalītas no peldbaseiniem un karstajām vannām (Lutz et al., 2011). Savukārt klīniski veselu cilvēku urīna paraugos atklāja 29\% rezistentu P. aeruginosa pret gentamicīnu (Chikwendu et al., 2010).

\subsection{Biomateriālu veidi un pielietojums}

Biomateriālu evolūcija daudzu gadu laikā ir strauji attīstījusies, un mūsdienās biomateriāli tiek izmantoti jebkurā medicīnas nozarē - ne tikai lai glābtu pacienta dzīvību, bet arī lai veiktu pacienta aprūpi un diagnostiku. Joprojām notiek meklējumi pēc ideālā biomateriāla. Šajā sacensībā tiek izmantotas daudzas biomateriālu grupas (Huebsch et al., 2009).

Medicīnā izmantojamos biomateriālus var iedalīt vairākās grupās atkarībā no to pielietojuma, uzbūves un izmantošanas. Pēc biolog̣iskā uzdevuma biomateriālus iedala 1) toksiskajos biomateriālos, kuri izraisa toksisku reakciju uz apkārtētajiem audiem, 
2) bioinertajos biomateriālos, kuri nekādā veidā nereaǵē ar cilvēka ķermeņa audiem un šūnām, un 3) bioaktīvajos biomateriālos, uz kuriem notiek pastiprināta audu reǵenerācija un reakcijas (Chatzistavrou et al., 2015). Pēc tā, cik ilgi biomateriālus paredzēts izmantot, tos iedala divās apakšgrupās - pagaidu un paliekošajos (uz visu atlikušo dzīvi) biomateriālos. Pagaidu biomateriālus iedala neuzsūcošos un uzsūcošos. Neuzsūcošos biomateriālus pēc kāda noteikta laika tie ir jāizṇem, kad, piemēram, ir notikusi kaulu piln̄̄ga sadzī̌sana. Savukārt uzsūcošie biomateriāli laika gaitā uzsūcas, un nav vajadzīga to izṇemšana (DiZerega et al., 2010). Biomateriālus iedala arī pēc to rakstura, un šî grupa veido lielāko un plašāk izmantoto biomateriālu klasi.

Metāla un metālisko sakausējumu biomateriālus plaši izmanto ortopēdiskajās operācijās. Biežāk izmantotie metāli šāda veida biomateriāliem ir dzelzs, titāns, niķelis un kobalts (Chen et al., 2015). Titānu un titāna sakausējumus visbiežāk izmanto zobārstniecībā zobu implantātiem (Yamagami et al., 2014).

Keramikas biomateriālu galvenā priekšrocība starp visiem biomateriāliem ir to līdzība kaulam, kas padara šo biomateriālu plaši izmantojamu ortopēdiskos un dentālos implantātos ar labām osteointegrācijas spējām. Galvenie keramikas biomateriāli ir hidroksiapatīts, kalcija fosfăti un bioaktīvais stikls (Höland et al., 2008; Sáenz et al., 1999).

Arvien populārāka kḷūst polimēru biomateriālu izmantošana - zobu implantātos, ortopēdiskās protēzēs un lokālas medikamentu izdales sistēmās. No polimēru biomateriāliem ir vieglāk pagatavot vajadzīgo formu, salīdzinot ar citiem biomateriāliem, tāpēc tos lieto zobu implantātos, intravenozos katetros, mākslīgo sirds vārstuḷu, diegu, lēcu veidošanā (Seala et al., 2001). Polimēri, kuriem piemīt bionoārdīšanās spēja, tiek izmantoti ne tikai antibiotisko vielu, bet arī anestēzijas līdzekḷu un citu zāļu izdalīšanai (Kohane et al., 2008). Biomateriālu daudzveidīgā izmantošana ir atspoguḷota 1.3. attēlā. 


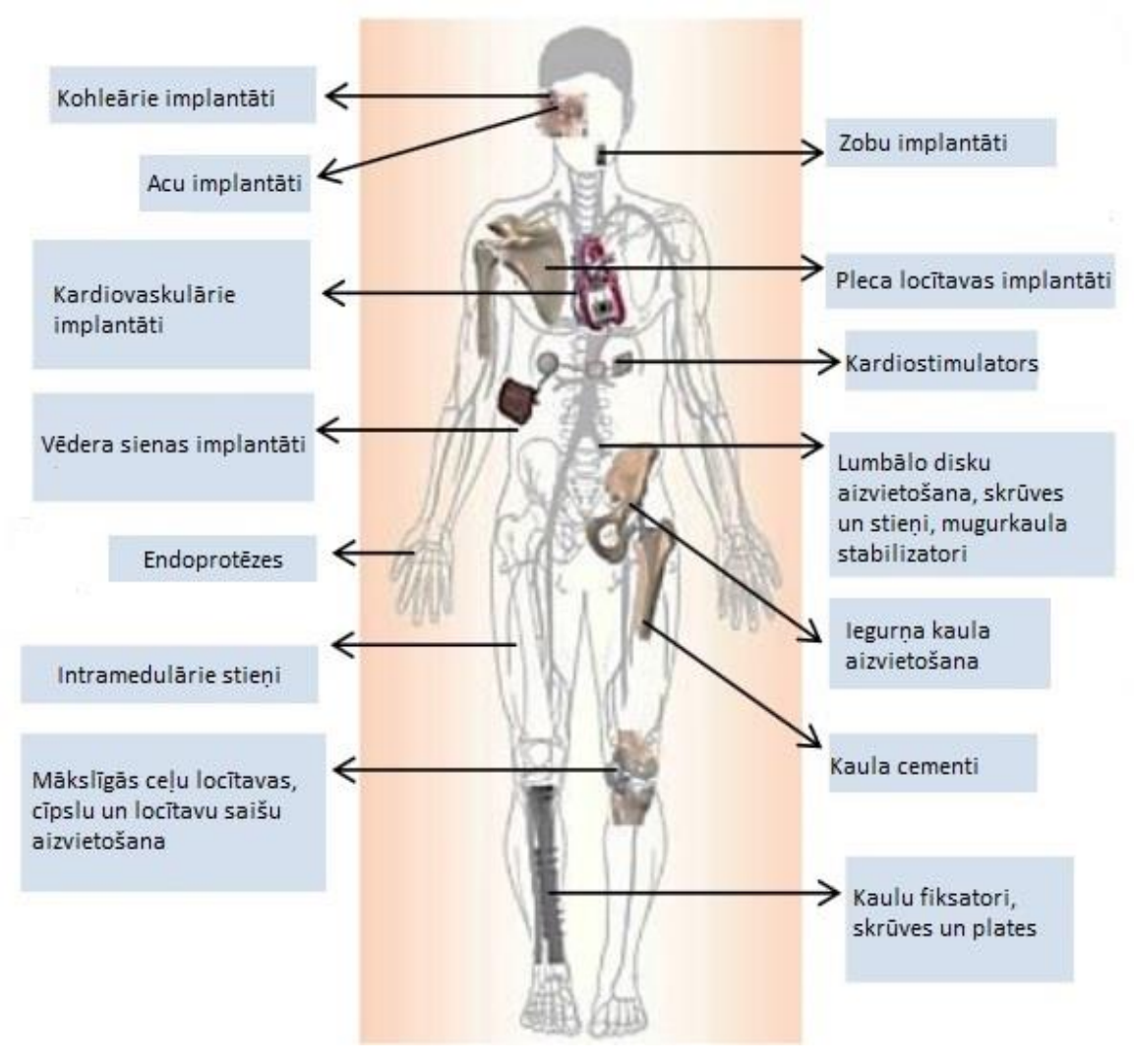

1.3. attēls. Biomateriālu izmantošana cilvēka ķermen̄̄

(pēc Patel et al., 2012)

\subsubsection{Biomateriālu saistītās infekcijas}

BAI ir infekcijas, kas rodas pēc dažādu biomateriālu vai implantātu lietošanas cilvēka organismā. Atkarībā no biomateriāla novietojuma un atrašanās ilguma organismā tie var kḷūt par dažādu infekciju perēkli (Darouiche, 2001). BAI bieži vien ir grūti ārstējamas, jo baktērijas, kas piesaistās un kolonizē biomateriālus, ir spējīgas producēt biofilmas. Ārstēšanu apgrūtina arī baktēriju rezistence pret antibiotiskajām vielām, kuras tiek izmantotas ārstēšanas procesā (Stewart et al., 2001). Tāpēc, lai izvairītos no pacienta dzīvības apdraudējuma un lielākas komplikāciju attīstības, implantāti tiek izņemti un aizvietoti ar jauniem, līdz ar to radot papildu dzīvības apdraudējumu un diskomfortu pacientiem, kā arī palielina kopējās ārstēšanas izmaksas, lai sekmīgi izārstētu BAI (Pittet et al., 1994).

Ir vairāki veidi, kā baktērijas var nokļūt uz biomateriāla. Visbiežāk BAI attīstās pēc biomateriāla implantācijas operācijas, kad biomateriāls tiek kontaminēts ar ādas un gḷotādas normālās mikrofloras baktērijām. Bieži implantātu operācijas tiek veiktas cilvēka organismā nesterilā vidē, piemēram, implantējot zobus mutes dobumā, kur mutes normālā mikroflora var kḷūt par BAI iemeslu. Operāciju zālē ir atrodami 20-60 KVV/m³ baktēriju, kas var būt BAI attīstības iemesls (Desai et al., 2012). Otrs galvenais BAI attīstības iemesls ir baktēriju 
hematogēna diseminācija no kāda cita infekcijas avota cilvēka ķermenī (Trampuz et al., 2005).

Lai biomateriāli būtu droši un pildītu tiem paredzēto funkciju, tie jāpasargā no iespējamas kontaminācijas ar baktērijām, kuras būtu spējīgas piesaistīties pie biomateriāla un attīstît infekciju. Ir vairāki veidi, kā biomateriālus iespējams pasargāt no baktēriju piesaistes pie tiem. Var modificēt vai izveidot biomateriāla virsmu tā, lai baktērijām nebūtu iespējams piesaistīties, vai arī samazināt baktēriju daudzumu, kuras būtu spējīgas piesaistīties biomateriālam (Banerjee et al., 2011). Biomateriālu virsmas var pārklāt ar elementiem, piemēram, sudrabu, kam piemīt spēja inaktivēt baktērijas pirms piesaistīšanās pie biomaterāla. Šādus biomateiālus ar subraba daļiņu pārklājumu izmanto urīnkatetros, lai samazinātu urīncel̦u infekciju rašanos pacientiem pēc urīnpūş̌la katetrizācijas (Johnson et al., 2012).

Lai panāktu biomateriāliem vislabāko antibakteriālo efektu, tiem pievieno antibiotiskās vielas, kuras izdalās no biomateriāla pēc tā implantācijas operācijas. Šāda veida biomateriālus izmanto stentos, visdažādākajos katetros, ķirurǵiskajos diegos un kaulu aizvietojošos implantos (Wu et al., 2006). Taču nepietiek tikai ar antibakteriālajām īpašībām biomateriālam pēc implantācijas ir jāpiemīt arī biosaderībai ar apkārtējiem audiem (Morais et al., 2010). Apvienojot biomateriāla virsmas, antibakteriālās, biosaderības un citas īpašības, varētu iegūt ideālo biomateriālu (1.4. attēls) (Busscher et al., 2012). 


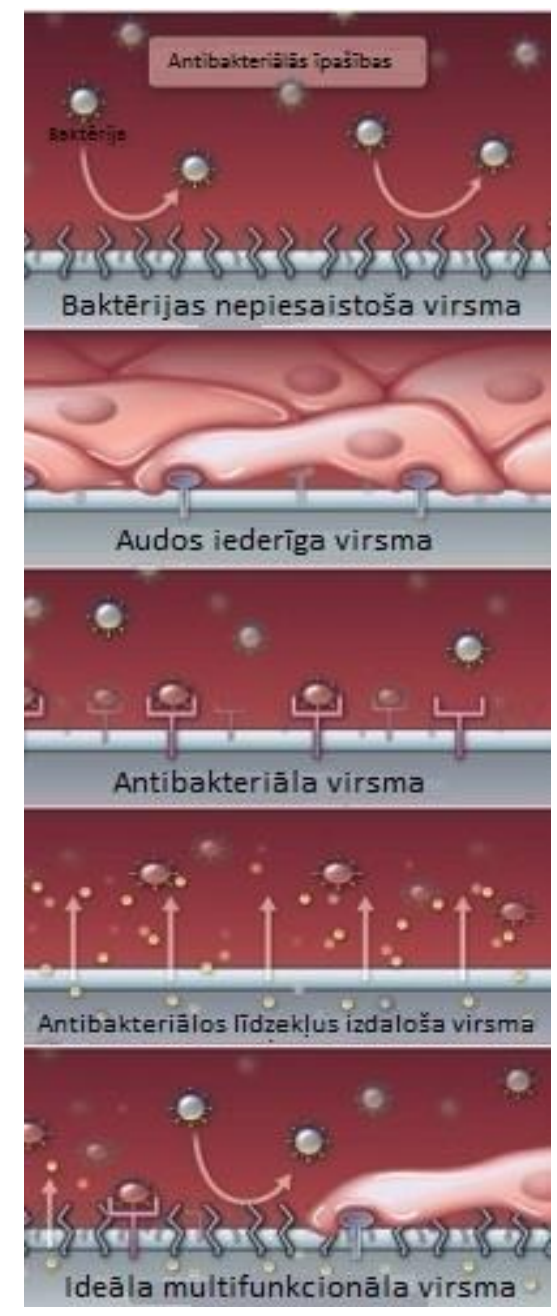

1.4. attēls. Biomateriāla īpašību daudzveidība

(pēc Busscher et al., 2012)

\subsubsection{Biomateriālu saistīto infekciju ierosinātāji un biežums}

BAI ierosinātāju dažādība ir plaša no normālās cilvēka mikrofloras pārstāvjiem līdz pret antibiotiskajām vielām rezistentām baktērijām. Bieži vien BAI ierosinātāji ir saistīti ar biomateriāla operācijas vietu cilvēka ķermen̄i vai implantāta pielietojumu. Piemēram, urīnceļu infekcijas pēc urīnpūšļa katetrizācijas biežāk ierosina gramnegatīvas baktērijas, savukārt ortopēdiskās implantātu infekcijas biežāk ierosina grampozitīvas baktērijas. Visbiežākais urīnceḷu infekciju ierosinātājs pēc urīnpūšșa katetrizācijas ir E. coli (Hooton et al., 2010), kā arī P. mirabilis (Jacobsen et al., 2008), P. aeruginosa un koagulāzes negatīvie Staphylococcus (S. epidermidis, S. saphrolyticus) (Nicolle, 2014). Koagulāzes negatīvie stafilokoki, visbiežāk S. epidermidis, ir biežākais ortopēdisko protēžu infekciju ierosinātājs. Gandrīz 60\% no visiem ortopēdisko protēžu infekciju gadījumiem ierosina S. epidermidis. No koagulāzes pozitīvajiem stafilokokiem, kuri ierosina ortopēdisko protēžu infekcijas, ir S. aureus un MRSA, un to biežums ir līdz 20\% (Ribeiro et al., 2012). Vēl citas grampozitīvās baktērijas, 
kuras ierosina ortopēdisko protēžu infekcijas, līdz 10\% gadījumu ir Streptococcus spp. Gramnegatīvās baktērijas (Enterobacteriaceae spp., P. aeruginosa u. c.) ierosina nelielu dalı (3-6\%) no ortopēdisko protēžu infekciju gadījumiem (Trampuz et al., 2005). Keratītu pēc kontaktlēcu lietošanas var ierosināt $P$. aeruginosa (Choy et al., 2008). Staphylococcus spp., Klebsiella spp., Propionibacteria spp. un citas baktērijas ir vieni no biežākajiem sirds stimulatoru infekciju ierosinātājiem (Tischer et al., 2014). Bioprotēžu vārstuḷu endokardīta ierosinātāju diapazons variē, bet $23 \%$ gadījumu ierosinātājs ir S. aureus. No šiem gadījumiem biežākais ierosinātājs ir MSSA, nevis MRSA, savukārt 16,9\% gadījumu ierosinātājs ir koagulāzes negatīvie Staphylococcus, kuriem seko viridans grupas Streptococcus $(12,1 \%)$, bet gramnegatīvās baktērijas (E. coli, P. aeruginosa) ir ierosinātājs mazāk par 1\% gadījumu (Wang et al., 2007). BAI biežums un implanta lokalizācija apkopota 1.2. tabulā.

1.2. tabula

\section{BAI biežums atkarībā no lokalizācijas}

\begin{tabular}{|c|c|c|c|}
\hline Lokalizācija & Implants & Incidence, $\%$ & Autors \\
\hline Zemāda & Sirds stimulators & $3-7$ & $\begin{array}{c}\text { Tischer et al., } 2014 . \\
\text { Darouiche et al., } 2001\end{array}$ \\
\hline Mīkstie audi & Krūšu implanti & $<7$ & $\begin{array}{c}\text { Seng et al., } 2015 . \\
\text { Dankert et al., } 1986\end{array}$ \\
\hline Asinsrites sistēma & Vārstuḷa bioprotēzes & $1,0-3,0$ & $\begin{array}{l}\text { Misawa et al., } 2015 . \\
\text { Wu et al., } 2006\end{array}$ \\
\hline Kauli, saites & Cel̦a locītava & $1,1-4,0$ & $\begin{array}{c}\text { Pulido et al., } 2008 . \\
\text { Darouiche et al., } 2001\end{array}$ \\
\hline Kauli, saites & Gūžas locītava & $0,7-4,0$ & $\begin{array}{c}\text { Pulido et al., } 2008 . \\
\text { Darouiche et al., } 2001\end{array}$ \\
\hline Urīnceļi & Urīnpūšļa katetrs & $14,4-33,0$ & $\begin{array}{c}\text { Darouiche et al., } 2001 . \\
\text { Vanhems et al., } 2008\end{array}$ \\
\hline
\end{tabular}

Biomateriālu lielā daudzveidība un plašā pielietošana, lai saglabātu pacientam dz̄ivīibu, atjaunotu organisma funkcionālo stāvokli un nodrošinātu labāku dzīves kvalitāti, ir risks infekciju attīstībai. Šo risku nosaka gan pacienta veselības stāvoklis un vecums, gan biomateriāla īpatnības, gan implantācijas operācijas plašums un anatomiskā vieta. BAI biežums ir atkarīgs no riska faktoru kopējā daudzuma (Busscher et al., 2012). 


\subsection{Iekaisums un iekaisuma marķieri. Antibakteriālie peptīdi}

Iekaisums ir organisma atbildes reakcija uz cilvēkam svešu materiālu, piemēram, biomateriālu, implantēšanu, bet biežāk - pret slimību ierosinošu kairinātāju, piemēram, baktēriju, vīrusu, sēni vai parazītu. Pret šo svešo kairinātāju, lai to iznīcinātu un neitralizētu, cilvēka imūnās sistēmas šūnas izdala citokīnus. Izdalītie citokīni ir signāli imūnās atbildes mehānismā, kurā attiecīgā signāla saņemšana vai nodošana stimulē vai neitralizē imūnkompetento šūnu atbildi uz kairinātāju. N̦emot vērā, ka katrs citokīns ir iesaistīts konkrētā imūnās atbildes procesā, tad tas, atrasts pacienta materiālā, var tikt izmantots iekaisuma diagnostikā kā iekaisuma marķieris (Libby, 2007).

\subsubsection{IL-10}

IL-10 ir pretiekaisuma citokīns. Tā galvenā funkcija ir samazināt citu citokīnu (TNF- $\alpha$, IL-6 un IL-1) darbības izpausmi. Tas veicina citu pretiekaisuma citokīnu izdalīšanos, kā arī samazina iekaisuma citokīnu receptoru daudzumu (Zhang et al., 2007). IL-10 inhibē T šūnu, monocītu, dentrītisko šūnu un makrofāgu aktivāciju, tādējādi samazinot un izbeidzot iekaisuma procesu (Moore et al., 2001). IL-10 izdala $\mathrm{Th}_{2}$ šūnas, T regulētājšūnas un makrofāgi, kā arī citas šūnas. IL-10 galvenokārt iedarbojas uz B šūnām un $\mathrm{Th}_{1}$ šūnām, attiecīgi aktivējot $B$ ly augšanu un inhibējot $\mathrm{Th}_{1}$ atbildi. $\mathrm{T}$ regulētājšūnas, izdalot $\mathrm{IL}-10$, novērš autoimūnus procesus (Charo et al., 2006). Nomācot $\mathrm{Th}_{1}$ veidošanos, tiek nomākta IFN- $\gamma$ produkcija no $\mathrm{Th}_{1}$ šūnām, un tas izraisa celulārās imūnās atbildes inhibīciju. IL-10 iedarbojas uz aktivētajiem makrofāgiem, izbeidzot to atbildes reakciju un apstādinot imūno atbildi pret ierosinātāju. IL-10 inhibē IL-12 ražošanu aktivētos makrofāgos un dendrītiskajās šūnās, kā arī inhibē kostimulatoru un MHC II ekspresiju uz šīm šūnām (Alexander et al., 2004). Kopumā IL-10 darbība ir saistīta ar nomācošu efektu uz celulāro imūno atbildi, bet veicinošu - uz humorālo imūno atbildi. IL-10 nomāc autoimūnos procesus un pārtrauc imūno atbildi pēc visu ierosinātāju neitralizēšanas (Rousset et al., 1992).

Lai noteiktu iekaisuma intensitāti, apkārtējos audos ap biomateriāla implantācijas vietu IL-10 nosaka in vivo pētījumos. Infekcijas procesa laikā audos ap biomateriālu novēro augstāku IL-10 intensitāti (Duarte et al., 2009). IL-10 audos ap biomateriālu var saglabāties augstā līmenī vairākas nedēḷas (Schuttea et al., 2009). 


\subsubsection{TNF- $\alpha$}

Galvenais TNF- $\alpha$ avots ir makrofāgi. Šī iekaisuma mediatora darbības efekti ir ļoti plaši, dažādi un atkarīgi no TNF- $\alpha$ līmeņa. Endotēlija šūnas TNF- $\alpha$ ietekmē var palielināt adhēzijas molekulu sintēzi un sintezēt hemokīnus, tādējādi norādot leikocītiem uz iekaisuma vietu. Ir atklāta TNF- $\alpha$ ietekme uz neitrofīlajām šūnām, aktivējot pašas šūnas un aktivizējot fagocitozes procesos tajos (Murray et al., 1997). TNF- $\alpha$ ietekmē palielinās T šūnu sintezēto citokīnu daudzums un notiek B šūnu augšanas stimulācija. TNF- $\alpha$ tiek dēvēts arī par kaheksīnu, jo tas iedarbojas uz taukšūnām, samazinot taukskābju izmantošanu, kas gala rezultātā noved pie kaheksijas (Espat et al., 1994). TNF- $\alpha$, aktivizējot trombocītus un izraisot intravaskulāro koagulāciju audzējā, var izraisīt audzēja nekrozi. TNF- $\alpha$ kā endogēnais pirogēns iedarbojas uz hipotalāmu un līdz ar to stimulē ķermeņa temperatūras celšanos un drudža attīstību. TNF- $\alpha$ var arī izraisīt sistēmiskas izmainas organismā - metabolisma izmaiņais, svara zudumu, apetītes zudumu. TNF- $\alpha$ piedalās imunologíiskajos procesos pret mikroorganismiem un specifisku audzēju nekrozē (Tracey et al., 1994).

Kā akūtās fāzes citokīnu produkcijas stimulators TNF- $\alpha$ veicina IL-1 un IL-6 produkciju, kuri kā akūtās fāzes citokīni iedarbojas uz aknu šūnām. Turpinot šo kaskādi, aknu šūnas producē akūtās fāzes proteīnus, piemēram, C reaktīvo proteīnu. Bojātie audi tiek atjaunoti, augot fibroblastiem, un to stimule TNF- $\alpha$ (Wajant et al., 2003).

Tā kā TNF- $\alpha$ ir viens no būtiskākajiem lokālā iekaisuma citokīniem, tā noteikšana kalpo par kritēriju, lai spriestu par iekaisumu pēc biomateriāla implantācijas. Paaugstināta TNF- $\alpha$ atrade vairākas dienas pēc implanta operācijas var liecināt par infekcijas procesu implantāta vietā, sevišķi, ja TNF- $\alpha$ dinamika nemainās. Tieši ar TNF- $\alpha$ atradi precīzāk var spriest par iekaisuma procesu implantācijas vietā nekā ar citu citokīnu atradi (Gul et al., 2010).

\subsection{3. $\beta$-defensīns-2}

Defensīni ir peptīdi, kuriem piemīt antibakteriāla darbība, veidojot jonu kanālus baktēriju membrānās, kas izraisa baktēriju nāvi. Defensīnus producē ādas un gḷotādu epitēlijšūnas, neitrofīlās šūnas, NK šūnas, T citotoksiskās šūnas. Defensīni tiek producēti nepārtraukti, bet to sekrēcija citokīnu ietekmē tiek pastiprināta. Atsevišşkas šūnas producē defensīnus kā atbildi uz IL-1 un TNF- $\alpha$ stimulāciju iekaisuma procesā. Baktērijas, baktēriju komponenti vai veidotie produkti ir stimuls šūnām producēt defensīnus. Defensīni ir mazi (līdz 30 aminoskābēm) peptīdi, kuri darbojas pret baktērijām, sēnīšu infekcijām un neitralizē 
vīrusus. Izšşirir $\alpha$ un $\beta$ defensīnu grupas, savukārt $\beta$ defensīniem izšķir četras apakšgrupas (Schröder et al., 2006).

$\beta$-defensīns-2 ir katjonu peptīdu defensīns, viens no defensīnu grupas antibakteriālajiem peptīdiem, kas piedalās nespecifiskās imunitātes procesos (Radek et al., 2007).

Gḷotādas epitēlijšūnu izdalītajam $\beta$-defensīnam-2 ir antibakteriāla iedarbība tieši pret gramnegatīvām baktērijām un Candida spp. $\beta$-defensīns-2 piedalās ādas un elpceļu sistēmas aizsargāšanā no iespējamajām bakteriālajām infekcijām un tiek izdalīts pēc kontakta ar baktērijām, visbiežāk ar $P$. aeruginosa, vai arī pēc citokīnu TNF- $\alpha$ un IL-1 stimulācijas (Schröder et al., 1999).

Ortopēdisko implantu infekcijas gadījumā tiek novērots paaugstināts $\beta$-defensīna-2 līmenis, tātad $\beta$-defensīna-2 intensitātes paaugstināšanās var kalpot kā diagnostiskais kritērijs infekcijas noteikšanai (Gollwitzer et al., 2013).

Pateicoties savām antibakteriālajām īpašībām pret grampozitīvām un gramnegatīvām baktērijām, antibakteriālie peptīdi tiek izmantoti biomateriālu virsmas modificēšanai un biomateriālu pasargāšanai no baktēriju adhēzijas uz tiem un biofilmas veidošanās (Costa et al., 2011). Piemēram, uretrāls stents ar antibakteriāliem peptīdiem neḷauj baktērijām piesaistīties pie virmas. Līdzīgs mehānisms ir uretrāliem stentiem ar antibiotiskajām vielām (1.5. attēls).

a

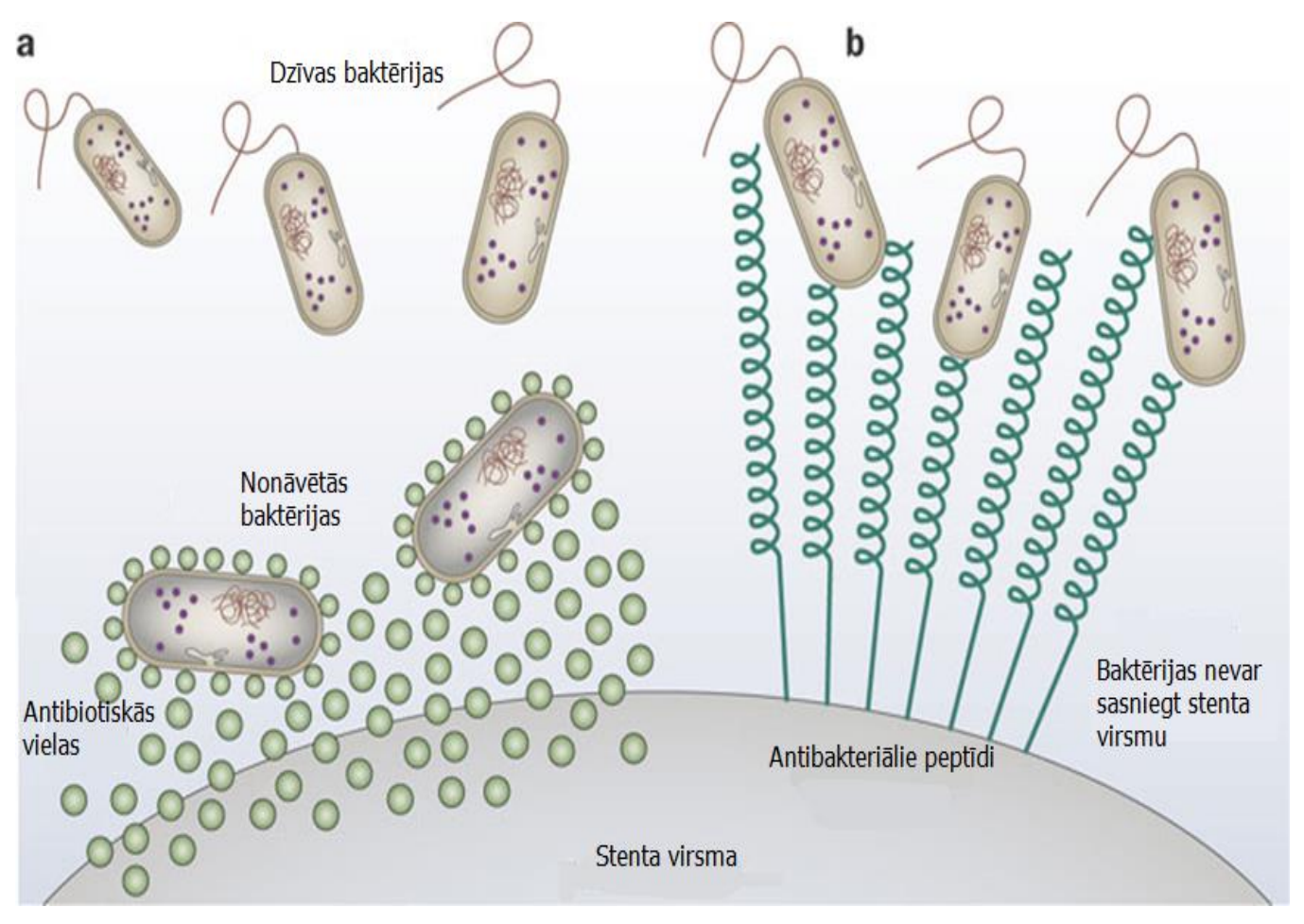

1.5. attēls. Uretrāls stents: a - ar antibiotiskām vielām, b - ar antibakteriāliem peptīdiem (pēc Chew et al., 2009) 


\subsection{S. epidermidis un $P$. aeruginosa raksturojums, patogentitātes faktori un ierosinātās saslimšanas}

\subsubsection{S. epidermidis raksturojums}

Pēc šūnas sienas uzbūves $S$. epidermidis ir grampozitīva nekustīga lodveida baktērija, apmēram $1 \mu \mathrm{m}$ diametrā. Baktērijas grupas novietojas vienkārtainā slān̄̄, kas līdzīgs vīnogu ķekara formai. Baktērijām piemīt fakultatīvi anaerobais respiratorais tips. Bioķīmiski baktērijas ir l̦oti aktīvas un fermentē glikozi, mannītu. Salīdzinot ar Streptococcus, S. epidermidis, kā visi stafilokoki, ir katalāzes pozitīvas baktērijas (Kloos et al., 1986).

S. epidermidis ir cilvēka ādas un g̣̣lotādas normālās mikrofloras pārstāvis, vairāk nekā 90\% no visas mikrofloras kopējā baktēriju daudzuma ir tieši S. epidermidis (Cogen et al., 2008). Kā normālās mikrofloras pārstāvis S. epidermidis producē antibakteriālos peptīdus pret iespējamajiem infekciju ierosinātājiem un stimulē ādas un ǵlotādas šūnas vēl vairāk producēt šos peptīdus, tādējādi $S$. epidermidis piedalās organisma nespecifiskās rezistences imūnajos procesos (Gallo et al., 2011).

Kaut arī S. epidermidis pieder pie normālās mikrofloras, ir sastopami pret antibiotiskajām vielām rezistenti celmi. MRSE rezistences mehānisms ir balstīts uz izmainītu PBP baktērijas šūnas sienā. PBP ir meticilīna un penicilīnu grupas antibiotisko vielu darbības mērksis, kuru izmaina, baktērijām iegūstot mecA gēnu. No klīniskā materiāla izolēta MRSE biežums var sasniegt pat 90\%, kas ir biežāks nekā MRSA biežums.

S. epidermidis spēj attīstīt rezistenci arī pret citām antibiotiskajām vielām, piemēram, pret makrolīdu grupas, aminoglikozīdu, fluorhinolonu un tetraciklīnu grupas antibiotiskajām vielām. Šì rezistence tiek nodota un kodēta ar plazmīdu palīdzību (Diekema et al., 2001).

\subsubsection{S. epidermidis patogenitātes faktori un ierosinātās infekcijas}

S. epidermidis ir oportūnisko infekciju ierosinātājs un viens no biežākajiem hospitālo infekciju ierosinātājiem. Tam nepiemīt agresīvi patogenitātes faktori, kas veiktu patogēno funkciju, bet tas infekcijas ierosina, pateicoties baktērijas virsmas faktoriem un polisaharīdu produkcijai.

S. epidermidis ir raksturīga adhēzija pie mākslīgajām virsmām vai saimniekorganisma šūnu protē̄niem. Adhēziju pie implantiem un biofilmas veidošanos nodrošina tādi patogenitātes faktori kā Aae, AtlE un teihonskābes. Aae un AtlE papildus piedalās piesaistē pie saimniekorganisma šūnu proteīniem. Bez šiem patogenitātes faktoriem pie saimniekorganisma šūnu proteīniem biofilmas veidošanās procesā piedalās arī $S d r F, S d r H$ un 
$S d r G$ patogenitātes faktori, kuri piesaistās pie kolagēna un fibrinogēna. Ebp faktors biofilmas veidošanās procesā piesaistās pie elastīna. Galvenie patogenitātes faktori, kuri nodrošina starpšūnu agregāciju un sasaisti, ir PIA, Aap un biofilmu asociētais proteīns Bap. S. epidermidis piemīt rezistence pret antibakteriālajiem peptīdiem. Rezistence tiek nodrošināta ar SepA proteāzi, kas degradē antibakteriālos peptīdus. Visi rezistences mehānismi pret antibakteriālajiem peptīdiem tiek regulēti ar Aps sistēmas palīdzību. Savukārt tādi patogenitātes faktori kā $P N A G$ un $P G A$ nodrošina ne tikai S. epidermidis rezistenci pret antibakteriālajiem peptīdiem, bet arī pret $\mathrm{IgG}$, fagocitozi un komplementa sistēmu (Otto, 2009).

No visiem koagulāzes negatīvajiem stafilokokiem S. epidermidis ir biežākais dažādu infekcijas slimību ierosinātājs (Rogers et al., 2009). Lielāks S. epidermidis ierosināto infekciju attīstības risks ir imūnsupresētiem, AIDS un vēža slimniekiem, kā arī cilvēkiem, kuri lieto implantētus biomateriālus.

Intravenozo katetru infekciju, ortopēdisko implantātu infekciju, mākslīgo sirds vārstuļu infekciju, sirds elektrostimulatoru infekciju un citu ar implantātiem saistītu infekciju biežākais ierosinātājs ir S. epidermidis, jo š̄ baktērija ir ādas mikrofloras sastāvā, savukārt šo ierīču lietošana ir saistīta ar neizbēgamu ādas kontaktu, bet implantācijas operācijas ķirurǵiskā brūce kalpo kā ieejas vārti baktērijai (Rogers et al., 2009).

Jaundzimušo asinsrites infekcijas attīstās pēc intravenozo vai peritoneālo katetru lietošanas. Citi riska faktori ir arī zems jaundzimušā svars un imūnsupresijas stāvoklis, bet neatkarīgi no riska faktora biežākie asinsrites infekciju ierosinātāji ir koagulāzes negatīvais stafilokoks (Venkatesh et al., 2006).

\subsubsection{S. epidermidis biofilmas veidošanās process}

S. epidermidis biofilmas veidošanās process ir daudzfunkcionālu etapu komplekss, kas gala rezultātā pasargā baktēriju no antibiotisko vielu iedarbības un imūnās sistēmas. Labvēlīgie apstākḷi l̦auj baktērijai ierosināt grūti ārstējamas infekcijas. Biofilmas veidošanās process ir atkarīgs no vairākiem faktoriem. Galvenais faktors ir virsma, uz kuras baktērija piesaistīsies un veidos biofilmu, virsmas īpatnības un raksturojums. Medicīnā tie ir biomedicīniskie implantāti, pie kuriem S. epidermidis spēj piesaistīties un veidot biofilmas, bet biofilmas var tikt veidotas arī ārējās vides apstākḷıos (upēs uz akmeņiem, dušās, caurulēs). Biofilmas var tikt veidotas gan uz dz̄ìām, gan mākslīgām virsmām (Agarwal et al., 2010).

Biofilmas veidošanās process ir atkarīgs no pašas baktērijas, jo šī spēja nepiemīt visām zināmajām baktērijām. Ir arī atsevišķas sēnes, kuras veido biofilmas. Atškşirības biofilmu 
veidošanā novēro pat vienas sugas baktēriju ietvaros. Ne visas S. epidermidis baktērijas ir spējīgas producēt PIA, bet tikai tās, kuras kodē icaADBC operonu. PIA ir nepieciešams biofilmas veidošanas procesā pēc baktēriju piesaistes (Mack et al., 2004).

Ar baktēriju adhēziju pie biomateriāla virsmas sākas biofilmas veidošanās pirmais posms. Adhēzijas etaps sastāv no diviem apakšetapiem, jo sākotnēji baktērijas veic adhēziju pie paša biomateriāla virsmas un noslēdz ar adhēziju uz biomateriāla esošajiem saimniekorganisma šūnu proteīniem. Uzreiz pēc implantācijas uz biomateriāla piesaistās saimniekorganisma proteīni, piemēram, fibrinogēns un fibrinonektīns, pie kuriem S. epidermidis piesaistās ar saviem patogenitātes faktoriem. Adhēziju uz biomateriāla virsmas nodrošina baktērijas teihonskābju gali un adhezīni - AtlE un Aae. Adhēzija pie saimniekorganisma šūnu proteīniem uz biomateriāla virsmas sākas ar $S d r F$ patogenitātes faktora piesaisti pie kolagēna un turpinās ar $S d r G$ patogenitātes faktora piesaisti pie fibrinogēna un $E b p$ patogenitātes faktora piesaisti pie elastīna. Lai gan AtlE un Aae spēj saistīties ar paša biomateriāla virsmu, tie spēj piesaistīties arī pie daudziem proteīniem (Fey et al., 2010).

Otrais S. epidermidis biofilmu veidošanās etaps ir baktēriju šūnu akumulācijas etaps. Šajā etapā notiek baktēriju savstarpējā adhēzija ar PIA, Bap un Aap patogenitātes faktoru līdzdalību. Grampozitīvajā šūnas sienā atrodamās teihonskābes piedalās baktēriju savstarpējās akumulācijas veidošanā (Büttner et al., 2015).

Pēc savstarpējās S. epidermidis adhēzijas notiek trešais biofilmas veidošanās etaps, kad notiek baktēriju šūnu proliferācija un nobriešana līdz biofilmas plīšanai un atdalīšanai no virsmas (1.6. attēls) (Stanley et al., 2004).

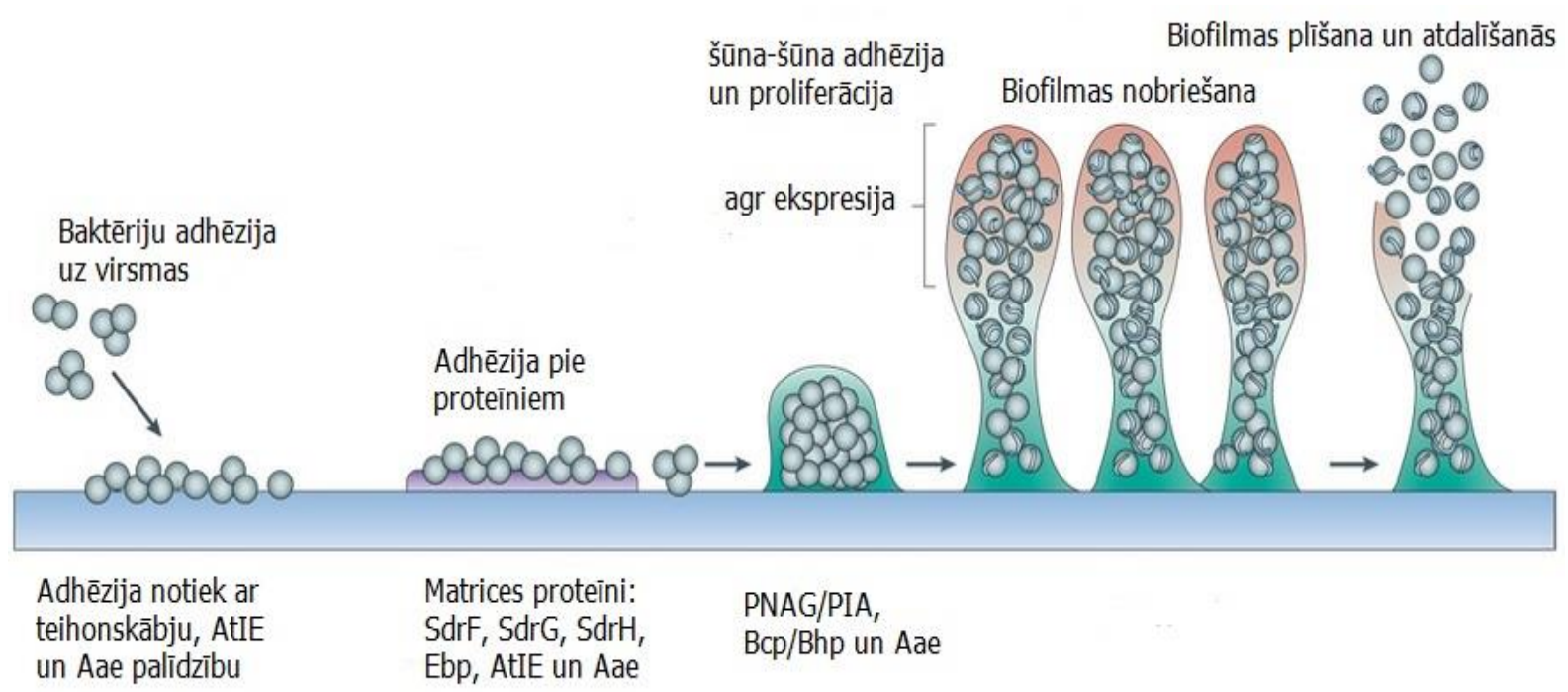

1.6. attēls. S. epidermidis biofilmas veidošanās process

(pēc Otto, 2009) 
Biofilmu rezistenci pret antibiotiskajām vielām nodrošina mehānismi ārpus biofilmas un mehānismi biofilmas iekšienē. Antibiotiskās vielas no ārpuses nevar tikt cauri glikokaliksa slānim, bet uz antibiotiskajām vielām, kas nokḷuvušas biofilmas vidē, iedarbojas mehānismi to inaktivācijai vai izdalei no baktērijas šūnas. Biofilmā esošās baktērijas producē enzīmus ( $\beta$-laktamāzes) antibiotisko vielu inaktivācijai un ar efluksa sūkṇa mehānismu izdala antibiotiskās vielas no šūnas (1.7. attēls) (Xiong et al., 2014).

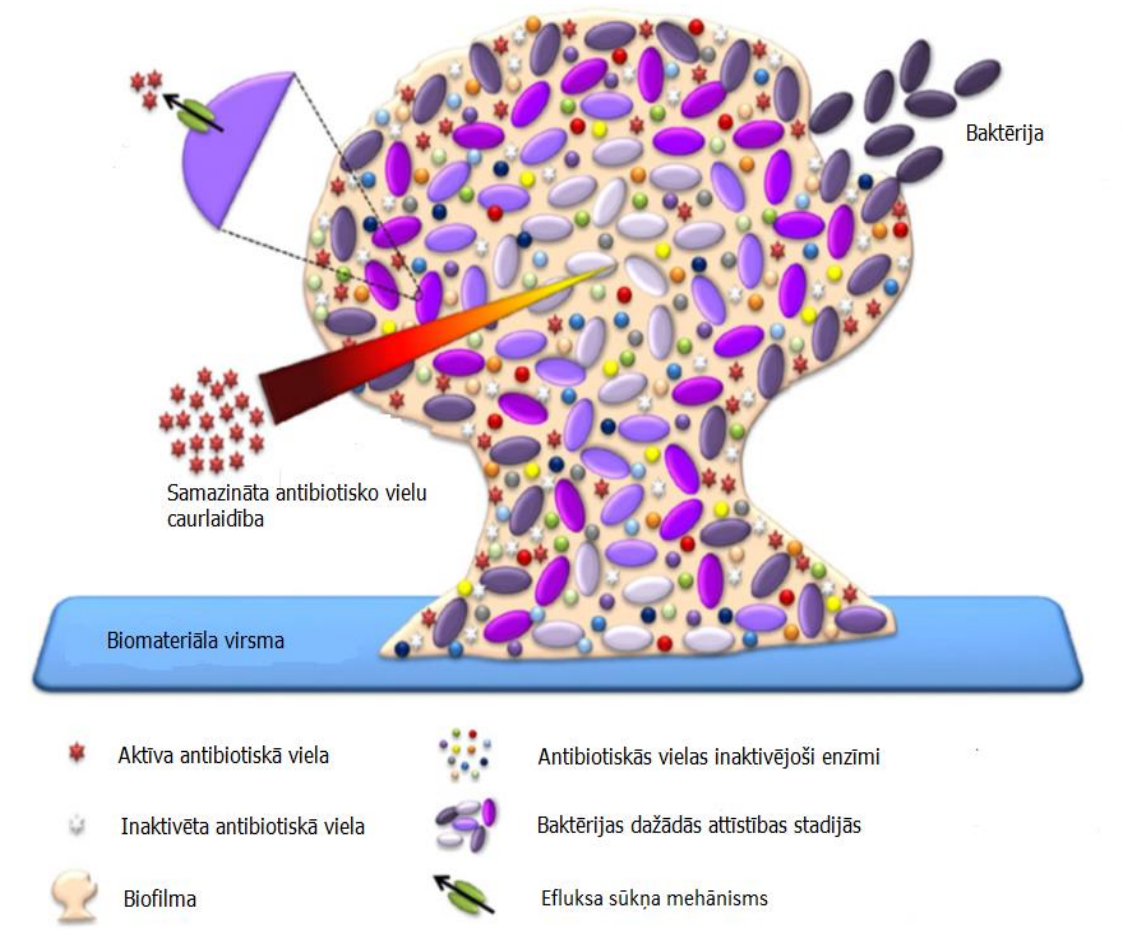

1.7. attēls. Biofilmu rezistences mehānismi pret antibiotiskajām vielām (pēc Xiong et al., 2014)

\subsubsection{P. aeruginosa raksturojums}

P. aeruginosa ir gramnegatīva nūjiņveida baktērija ar unipolāru viciņu. Pateicoties aerobajam respirācijas veidam, baktēriju plaši var atrast apkārtējā vidē, piemēram, augsnē, ūden̄̄, dzīvnieku mikroflorā un uz augiem, bet atsevišķai populācijas daḷai ir atrodama ādas, elpceļu un zarnu normālajā mikroflorā. P. aeruginosa ir viens no biežākajiem hospitāli ierosināto infekciju ierosinātājiem. Slimnīcas vidē baktēriju atrod sanitārajos mezglos (izlietnēs, tualetēs, dušās). Baktērija ir spējīga kontaminēt slimnīcā izmantotās ierīces un medicīniskos priekšmetus (mākslīgās elpināšanas aparatūru, dialīzes aparatūru). Atsevišksas baktērijas ir rezistentas pret dezinfekcijas šķīdumiem (Pollack, 1995).

P. aeruginosa ierosinātajām infekcijām ir apgrūtināta antibakteriālā terapija, jo baktērijai ir augsta rezistence pret antibiotiskajām vielām. Rezistence veidojas pret vairākām 
antibiotisko vielu grupām. Līdz 35\% P. aeruginosa ir rezistenta pret ciprofloksacīnu, bet līdz $22 \%$ rezistentas pret gentamicīnu. Rezistence pret $\beta$-laktāmiem sasniedz 20\%.

Baktērijas rezistence pret ciprofloksacīnu un fluorhinoloniem attīstās divējādi: ar efluksa sūkṇa mehānismu, vai arī baktērija izmaina ciprofloksacīna darbības mērķi (topoizomerāze IV un DNS žirāze).

Plašā baktērijas rezistence pret $\beta$-laktāmiem ir saistāma ar $P$. aeruginosa spēju producēt enzīmus, piemērām, penicilināzi, kas šķel̦ penicilīnā esošo $\beta$-laktāma gredzenu. Savukārt rezistence pret aminoglikozīdiem tiek panākta, izdalot enzīmus, kas ķ̄ìmiski modificē antibiotiskās vielas uzbūvi (1.8. attēls) (Lister et al., 2009).

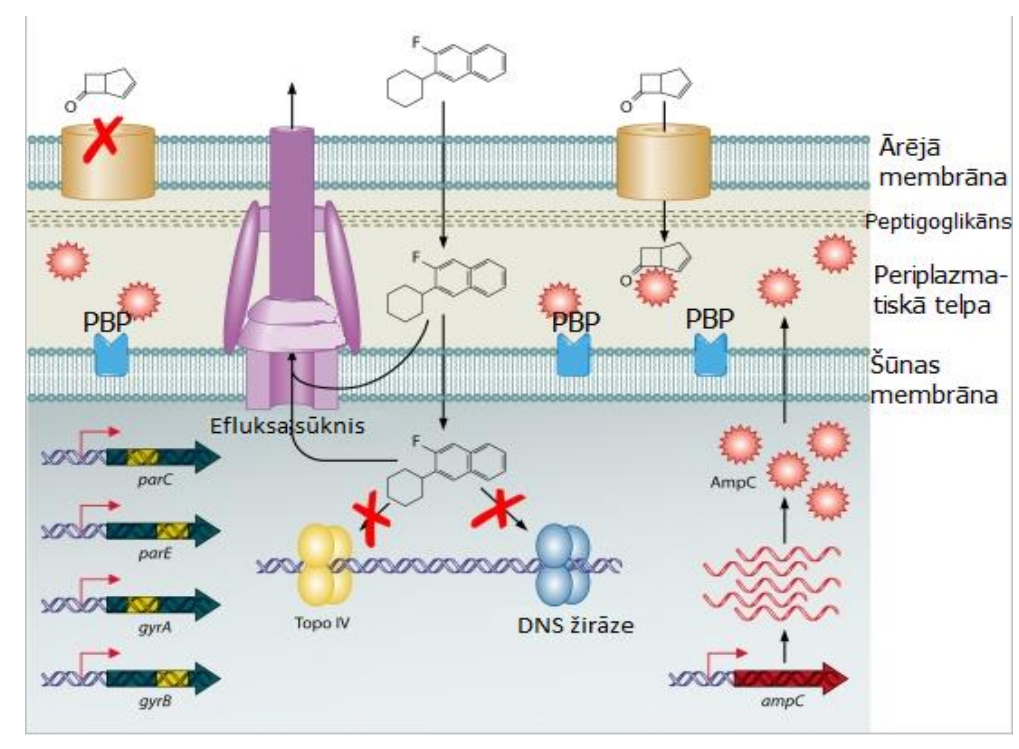

1.8. attēls. $\boldsymbol{P}$. aeruginosa antibakteriālās rezistences mehānismi (pēc Lister et al., 2009)

\subsubsection{P. aeruginosa patogenitātes faktori un ierosinātās infekcijas}

P. aeruginosa patogenitātes faktorus iedala divās grupas. Pirmās grupas patogenitātes faktori ir saistīti ar pašas baktērijas struktūrām, piemēram, LPS, kas stimulē citokīnu produkciju, un pacientam izpaužas kā šoks. Pie šīs grupas patogenitātes faktoriem pieder viciņa, pili, algināts un citi baktērijas adhezīni. Unipolāra viciṇa ir baktērijas kustîbu aparāts, bet ar pili palīdzību baktērija nodrošina adhēzijas funkciju un pret antibiotiskajām vielām rezistento plazmīdu nodošanu citām baktērijām. Algināts nodrošina baktērijas piesaisti pie trahejas epitēlija šūnām un rezistenci pret antibiotiskajām vielām, kā arī inhibē fagocitozi.

Otrā patogenitātes faktoru grupa ir ekstracelulāri producētie baktērijas patogenitātes faktori. Šajā grupā ietilpst eksotoksīns A, elastāzes, eksoenzīms S, eksoenzīms U un 
fosfolipāze C. Eksotoksīns A iedarbojas uz šūnām, inhibējot tajos proteīnu sintēzi un izraisot šo šūnu nekrozi. Šūnu nekrozi pastiprina eksoenzīms S ar savu citotoksisko iedarbību, bet eksoenzīmam U ir antifagocitāra iedarbība pret imūnās sistēmas šūnām.

Elastāzes iedalās divos apakštipos, LasB un LasA elastāzēs, tās nodrošina baktērijas invāziju audos. Kolagēns, elastīns un fibrīns šo elastāžu ietekmē tiek dedradēts. Turklāt elastāzes nodrošina baktērijas evāziju no $\operatorname{IgG}, \operatorname{IgA}$ un komplementa sistēmas. Fosfolipāzei C ir lokāls citolītisks efekts uz mērksa šūnām, veidojot plaušu atelektāzes $P$. aeruginosa izraisītu akūtu un hronisku infekciju gadījumā. Pie $P$. aeruginosa papildu patogenitātes faktoriem pieder piocianīns un pioverdīns, kuriem piemīt baktericīda iedarbība uz citām baktērijām un epitēlija skropstiņu imobilizācijas funkcija (Van Delden et al., 1998).

P. aeruginosa ierosina hospitāli iegūtas infekcijas pacientiem ar novājinātu imūno sistēmu vai pacientiem ar traumatizētu un bojātu epiteliāro barjeru.

Asinsrites infekcijas, ko ierosina P. aeruginosa, 21\% pacientu ir letālas. Mirstība no asinsrites infekcijas biežāka ir tiem pacientiem, kuri sākotnēji nesaņem atbilstošu antibakteriālo terapiju (Micek et al., 2005).

Intensīvās terapijas nodạ̦ās, lai uzturētu pacientiem normālu elpošanas funkciju, tiek veikta intubācija. Intubācijas caurule ir biomateriāls, kas bieži tiek kontaminēts ar $P$. aeruginosa uzreiz vai pāris dienas pēc intubācijas. Ventilatorasociētās pneimonijas biežākais ierosinātājs ir P. aeruginosa, kas saistīts ar pacienta intubāciju. Pacientu mirstība no ventilatorasociētās pneimonijas biežāka ir gadījumos, ja ierosinātājs ir $P$. aeruginosa (American Thoracic Society; Infectious Diseases Society of America, 2005).

Pacientiem ar ādas apdegumiem ir traucētas ādas funkcijas, un apdegumi kalpo kā ieejas vārti bakteriālajām infekcijām. No visām ādas infekcijām pēc apdegumiem 57\% gadījumu ierosinātājs ir P. aeruginosa (Estahbanati et al., 2002). Pēc ķirurǵiskas operācijas par baktēriju infekcijas ieejas vārtiem kḷūst ķirurgískā brūce. Šādas brūces parasti inficē gramnegatīvas baktērijas - E. coli (20,3\%), Klebsiella spp. (16,6\%), Proteus spp. (6,3\%), bet visbiežāk (29,6\%) - P. aeruginosa (Ranjan et al., 2010).

Cistiskās fibrozes slimniekiem $P$. aeruginosa infekcijas ir ar augstu letalitāti, jo baktērija ir spējīga kolonizēt elpceļu un plaušu šūnas, veidojot atelektāzes (Davies et al., 2002).

\subsubsection{P. aeruginosa biofilmas veidošanās mehānisms}

P. aeruginosa biofilmu veidošanās procesā izšķir piecas stadijas. Biofilmas pirmā stadija ir adhēzija pie biomateriāla, un sākotnēji tā ir atgriezeniska. Š̄is stadijas ilgums ir 
apmēram divas stundas. Pēc divām stundām sākas otrā biofilmas attīstības stadija (neatgriezeniskā adhēzija), kad baktēriju šūnas vairs neatdalās no biomateriāla virsmas. Neatgriezeniskās adhēzijas stadija ilgst 8 h no biofilmas veidošanās procesa sākuma. Adhēzija pie biomateriāla virsmas sākotnēji notiek ar baktēriju viciņu un IV tipa pilu palīdzību, bet turpinājumā adhēzija tiek panākta ar Psl eksopolisaharīdu (Harmsen et al., 2010). $P$. aeruginosa baktērijām ar flgK gēna mutāciju nav viciņas. Šādām baktērijām, salīdzinot ar viciņotām baktērijām, novēro samazinātu adhēzijas intensitāti uz biomateriāliem un arī biofilmas veidošanos. Līdzịga aina ir ar baktērijām, kurām ir mutācija pilA gēnā, kas nosaka, ka baktērijai nav pili, līdz ar ir samazinātas adhēzijas spējas (Barken et al., 2006; Sauer et al., 2002).

Psl eksopolisaharīds ne tikai nodrošina baktēriju adhēziju pie biomateriāla virsmas, bet arī uzsāk trešo biofilmas veidošanās stadiju - mikrokoloniju veidošanos. Biofilmas struktūra tiek noturēta ar $P s l$ eksopolisaharīda nodrošinātajiem baktēriju savstarpējiem kontaktiem. Agrīna savstarpējā baktēriju mijiedarbība tiek nodršinā ar Pel polisaharīdu (Wei et al., 2013). Abu šo polisaharīdu īpatnības l̦auj tiem piesaistīties un veidot biofilmas uz biomateriāliem un cilvēka šūnām. Psl eksopoliharīds saistās pie respiratorā epitēlija, īpaši cistiskās fibrozes slimniekiem (Ma et al., 2006). Mikrokolonija tiek veidota, līdz tās biezums sasniedz apmēram $10 \mu \mathrm{m}$ biezumu, un tas notiek apmēram pēc 14 stundām no biofilmas veidošanās procesa sākuma. Ceturtajā - nobriešanas - stadijā biofilma nobriest un palielinās apmēram 10 reižu. Šos izmērus biofilma sasniedz 4.-5. biofilmas veidošanās stadijā. Biofilmas palielināšanos izmēros stabilizēe eDNS izdalīšanās, kas nostiprina baktēriju savstarpējo adhēziju biofilmā (Rasamiravaka et al., 2015; Sauer et al., 2002).

Biofilmas veidošanās process noslēdzas ar piekto - dispersijas - stadiju. Šīs stadijas laikā biofilma plīst, un baktērijas pārvietojas no biofilmas uz brīvu biomateriāla virsmu, lai veidotu jaunas biofilmas (Sauer et al., 2002). P. aeruginosa biofilmu veidošanās process un laiki ir shematiski apkopoti 1.9. attēlā.

P. aeruginosa veidoto biofilmu rezistenci pret antibiotiskajām vielām un saimniekorganisma imūno sistēmu nosaka eksopolisaharīds - algināts, kas biofilmas veidošanās procesā biofilmā notur ūdeni un baktērijām vajadzīgās barības vielas (Ryder et al., 2007). 


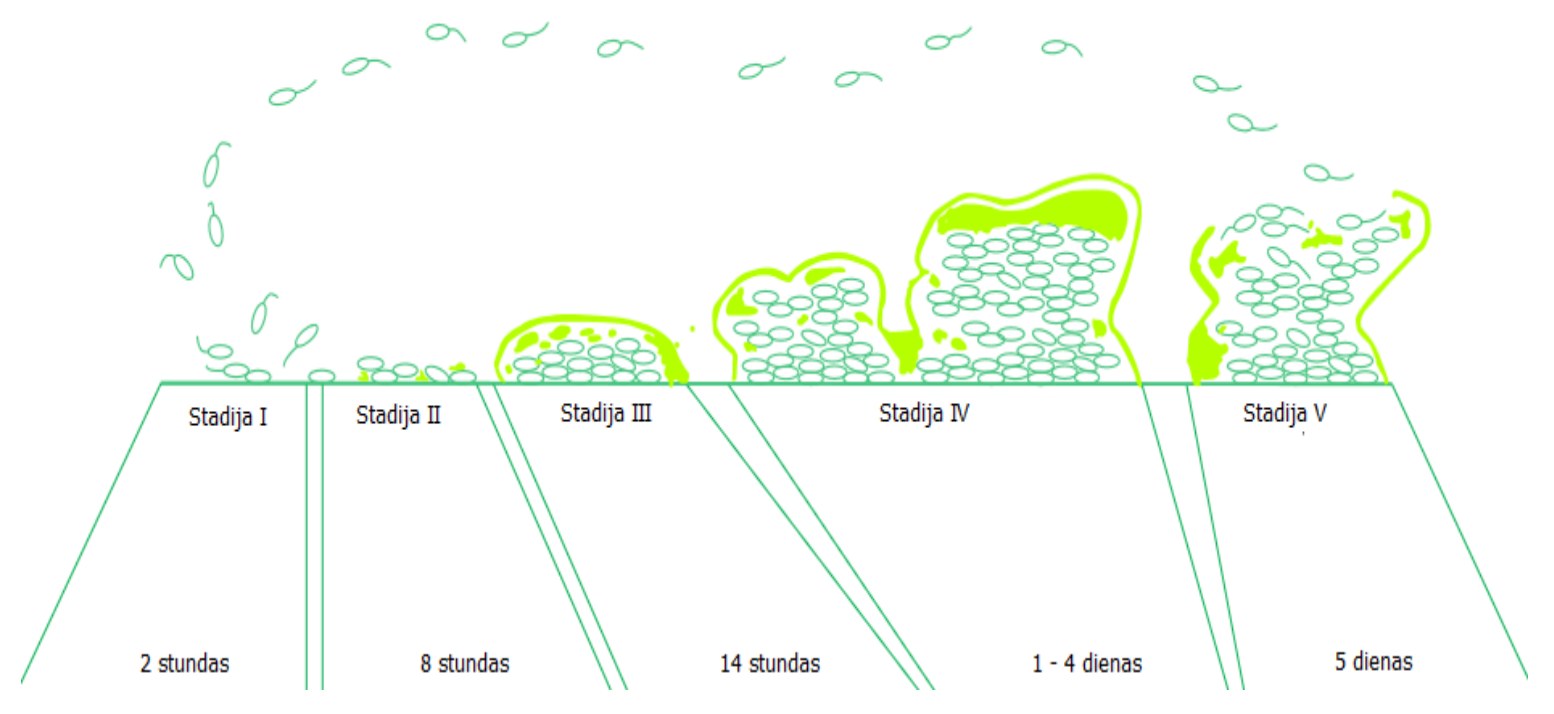

1.9. attēls. $P$. aeruginosa biofilmas veidošanās process un laiki (pēc Rasamiravaka et al., 2015)

\subsection{Bionoārdāmie polimēri, to raksturojums}

Bionoārdāmos polimērus izmanto daudzās medicīnas nozarēs, sadzīvē nepieciešamo lietu (iesaiņojuma maisiņu) izgatavošanā, rūpniecībā, lauksaimniecībā, kāâ arī sportā un elektronikā. Pēc ieguves veida izdala sintētiskos un dabīgos polimērus. Daudzi dabīgie polisaharīdi un to ķīmiskās modifikācijas tiek izmantotas kā dabīgie polimēri. Lignīns, ciete un celuloze ir tikai neliela daļa no dabīgajiem polimēriem. Lai arī sintētiskie polimēri tiek iegūti ķīmiskās sintēzes procesā, tiem piemīt spēja sadalīties dabīgos vides un fizioloǵiskā cilvēka vidē, kas dara iespējamu šo polimēru izmantošanu medicīnā un audu inženierijā (Vroman et al., 2009).

Medicīnā izmantojamajiem bionoārdāmajiem polimēriem ir jāpiemīt vairākām īpašībām, lai tos droši varētu izmantot kā implantētus biomateriālus cilvēka organismā. Šie polimēri un polimēru sadalīšanās produkti nedrīkst būt toksiski apkārtējiem audiem. Atkarībā no izmantošanas mērḳa šiem polimēriem jābūt mehāniski izturīgiem, kā arī jābūt iespējai tos sterilizēt. Šādi biomateriāli tiek izmantoti īslaicīgi, noteiktu laika periodu, un tie funkcionē konkrētu laiku, tāpēc, izmantojot bionoārdāmos polimērus, ir jāzina to noārdīšanās laiks un ātrums (Gomes et al., 2004).

Ir iespējami vairāki veidi, kā polimēri tiek noārdīti, bet visos gadījumos kopīgais ir polimēra noārdīšanās līdz monomēriem. Izšķir enzimātisko, hidrolītisko un mikrobiologiiskās degradācijas veidu.

Hidrolītiskās degradācijas laikā polimēra saites tiek šķeltas ar ūdens molekulu palīdzību, veidojot monomērus. Implantējot bionoārdošos polimērus cilvēka organismā, uz 
tiem iedarbojas cilvēka enzīmi, nodrošinot polimēra degradāciju līdz oligomēriem, dimēriem un monomēriem. Mazās polimēru molekulas mineralizējas par $\mathrm{CO}_{2}$ un $\mathrm{H}_{2} \mathrm{O}$. Šì degradācijas kaskāde ir pamats enzimātiskajai degradācijai (Suming et al., 2002).

Mikrobiolog̣iskās polimēru degradācijas laikā sēnītes (Penicillium spp., Aspergillus spp.) un baktērijas spēj izdalīt ekstracelulārus enzīmus, kuri šķel̦ polimēru. Degradācija var notikt gan aerobos, gan anaerobos apstākḷlos (Tokiwa et al., 2009).

Bionoārdāmie polimēri tiek izmantoti divējādi - vai nu kā atseviškss biomateriāls vai savienots kopā ar citu biomateriālu, piemēram, hidroksiapatītu. To lielākais pētniecības un izmantošanas virziens ir lokāla, ilglaicīga zāļu izdale (Ulery et al., 2011).

Pacientiem ar koronāro artēriju stenozi tiek izmantoti bionoārdoša polimēra stenti, lai atjaunoto artēriju funkcionālo darbību un izdalītu lokāli zāles (Tamai et al., 2000). Ķirurǵijā jau gadu desmitiem ir pazīstami un tiek izmantoti bionoārdoši polimēru diegi. Jaunākie pētījumi liecina, ka bionārdošo diegu īpašības tiek apvienotas ar antibakteriālajām īpašībām gan pret grampozitīvām, gan pret gramnegatīvām baktērijām, lai samazinātu brūču infekciju attīstību pēc ķirurǵiskajām operācijām (Lee et al., 2013).

Kaulus fiksējošas ierīces, skrūves, ortopēdiskās plates un citi kaulu aizvietojoši materiāli tiek veidoti no bionoārdošajiem polimēriem, ko izmanto ortopēdiskās operācijās. Metāliskām platēm, kuras tiek izmantotas noteiktu laiku, ir nepieciešama atkārtota operācija, lai tās izṇemtu, bet, izmantojot bionoārdošos polimērus, kam piemīt labas mehāniskās īpašības, šāda operācija nav nepieciešama (Navarro et al., 2008).

PGA, PLLA, PLGA, PHB, PCL ir vieni no daudzajiem bionārdāmajiem polimēriem, kas tiek izmantoti gan medicīnā, gan citās nozarēs (Ulery et al., 2011).

\subsubsection{Polipienskābes polimērs}

PLLA savu izmantošanas popularitāti ir ieguvis, pateicoties tam, ka to iegūst no atjaunojamiem dabas resursiem, piemēram, cietes. PLLA ir termosplastisks un bionoārdāms polimērs ar kušanas temperatūru $175{ }^{\circ} \mathrm{C}$, tā ķ̄imiskā formula ir $\left(\mathrm{C}_{3} \mathrm{H}_{4} \mathrm{O}_{2}\right)_{\mathrm{n}}$ (1.10. attēls). PLLA biomateriālus plaši izmanto ortopēdijā, jo PLLA piemīt labas mehāniskās īpašības $(4,8$ GPa) (Ulery et al., 2011). Zobārstniecībā un sejas un žokḷu ķirurǵijā PLLA biomateriālus (PLLA plāksnītes un skrūves) izmanto, ja ir apgrūtināta kaulu fiksācija un nevar izmantot citas metodes.

Ja ortopēdisko operāciju laikā izmantoti biomateriāli ar PLLA, pēc PLLA bionoārdīšanās šo vietu aizpildīs kaulaudi (Shikinami et al., 2001). 


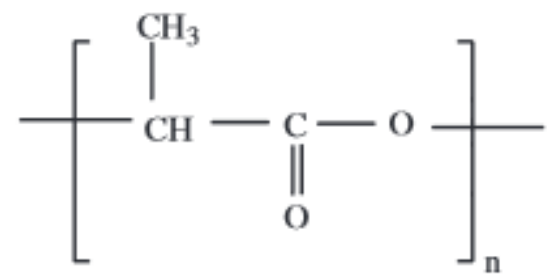

\subsection{0. attēls. PLLA ķīmiskā struktūra}

(Nair et al., 2007)

Audu inženierijā PLLA izmanto labo biosaderības īpašību dēḷ, tā sadalīšanās laikā neveidojas audiem toksiski produkti. Lēnais noārdīšanās ātrums l̦auj izmantot šo polimēru lokālai un kontrolētai zāḷu, piemēram, antibiotisko vielu, izdalei. PLLA virsmu var pārklāt ar biologiski aktīvām vielām, uzlabojot biomateriāla biosaderību ar apkārtējiem audiem. PLLA pārklāšanai izmanto kolagēnu un bāzisko fibroblastu augšanas faktoru, tādējādi paaugstinot hondrocītu metabolisko aktivitāti (Ma et al., 2005).

\subsubsection{Polikaprolaktona polimērs}

PCL piemīt zemas mehāniskās īpašības (23MP), kas ierobežo tā izmantošanu, piemēram, ortopēdijā, bet kompozītmateriālos ar kalcija fosfātiem to izmanto kaulu aizvietošanā (Mondrinos et al., 2006). PCL izmantošanu ierobežo arī tā zemā kušanas temperatūra - 55 līdz $60{ }^{\circ} \mathrm{C}$. PCL ķīmiskā formula ir $\left(\mathrm{C}_{6} \mathrm{H}_{10} \mathrm{O}_{2}\right)_{\mathrm{n}}$ (1.11. attēls). Tā uzbūvē ir hidrolītiski labilas esteru saites, kas tiek šķeltas hidrolizācijas procesā. Biodegradācijas ātrums ir lēnāks nekā PLLA.

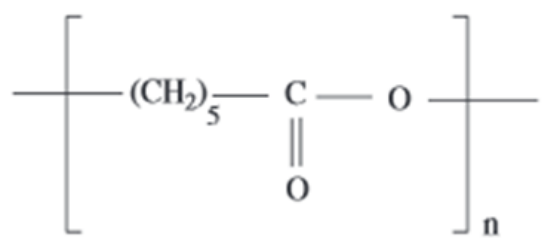

\subsection{1. attēls. PCL k̦īmiskā struktūra}

(Nair et al., 2007)

Teicamo biosaderības īpašību dēḷ PCL izmanto audu inženierijā un lokālās un kontrolētās zāḷu izdales sistēmās. Lai samazinātu periodontālu infekciju risku, kontrolētai un ilglaicīgai antibiotisko vielu izdalei tiek ieteikts lietot PCL šķiedras ar gentamicīnu, kuras uzrāda teicamas antibakteriālās īpašības pret S. epidermidis in vitro (Chang et al., 2008). 


\section{MATERIĀLS UN METODES}

\subsection{Biomateriālu paraugi}

\subsubsection{HAp/PLLA+cipro un HAp/PLLA+genta}

Hidroksiapatîta pulveris tika sagatavots ar slapjās ķīmiskās nogulsnēšanas metodi no kalcija oksīda (Sigma-Aldrich, UK), $\geq 97 \%$ ) un ortofosforskābes (Sigma-Aldrich, UK) šksīduma (Sokolova et al., 2014). Iegūtie jaunsintezētie pulveri tika sapresēti tabletēs $(\mathrm{d}=10$, $\mathrm{H}=3 \mathrm{~mm}$ ). Visi paraugi tika termiski apstrādāti $1100{ }^{\circ} \mathrm{C}$ temperatūrā 1 stundu ilgi. Pirms HAp paraugu piesūcināšanas ar antibiotiskajām vielām gentamicīns (koncentrācija $40 \mathrm{mg} / \mathrm{ml}$ ) vai ciprofloksacīns (koncetrācija $100 \mathrm{mg} / 10 \mathrm{ml}$ ) tika izšksīināâts dejonizētā ūden̄̄. HAp paraugi tika piesūcināti ar ūdens-zāḷu šķīidumu istabas temperatūrā atmosfềras spiedienā, pēc tam žāvēti $37{ }^{\circ} \mathrm{C}$ temperatūrā. Daļa no sagatavotajiem paraugiem tika izmantoti pārklāšanai ar PLLA. PLLA pārklājums HAp paraugiem tika pagatavots no 10 wt\% poli(L-pienskābes) (Nature Works LLC, Mw = $110 \mathrm{kDa}$ ) šķīduma ar dihlormetānu (DCM) (Sigma-Aldrich, UK). PLLA tika izšksīināts DCM šķīdumā, to maisot 2 stundas istabas temperatūrā. Polimēra šķīdums tika infiltrēts HAp biokeramikas paraugos, izmantojot vakuuma impregnēšanas metodi 500 mbar spiedienā 15 minūtes. Pārklātie paraugi tika žāvēti istabas temperatūrā 24 stundas ilgi. Atvērtā un kopējā porainība tika noteikta ar Arhimēda metodi, kas balstīta uz to, ka pielietotais spēks ir vienāds ar pārvietotā šķ̄iduma masu (Locs et al., 2013). Atvērtās porainības līmenis ir 34\%, bet kopējā porainība - 36\%. Ar SEM izmeklējot pārklāto paraugu šķērsgriezumu, bija redzams, ka HAp/PLLA paraugi, kas pārklāti ar 10 wt\% PLLA, ir poraina mikrostruktūra ar poru izmēru diapazonu no 200 līdz 500 nm (2.1. attēls, kreisā puse). Tika iegūti paraugi ar PLLA pārklājumu, kas ir 2-5 $\mu \mathrm{m}$ biezi (2.1. attēls, labā puse). Lai izvērtētu, vai PLLA piemīt antibakteriālas īpašības, tika pagatavoti HAp/PLLA paraugi bez antibiotiskajām vielām.

Pēc šādas pašas metodikas tika pagatavoti $\downarrow$ HAp/PLLA+cipro, $\downarrow$ HAp+cipro un $\downarrow$ HAp/PLLA paraugi $(\downarrow-$ turpmāk darbā apzīmē kompozītmateriālus ar samazinātu porainības līmeni), kuriem atvērtā un kopējā porainība ir zemāka, respektīvi, 15\% - atvērtā porainība un 19\% - kopējā porainība. Paraugi sintezēti, lai noskaidrotu, kā porainības līmenis ietekmē antibakteriālās darbības laiku. Katrai kompozītmateriālu grupai pret abu baktēriju kultūrām tika izgatavoti 8 paralēlie sērijas paraugi. 

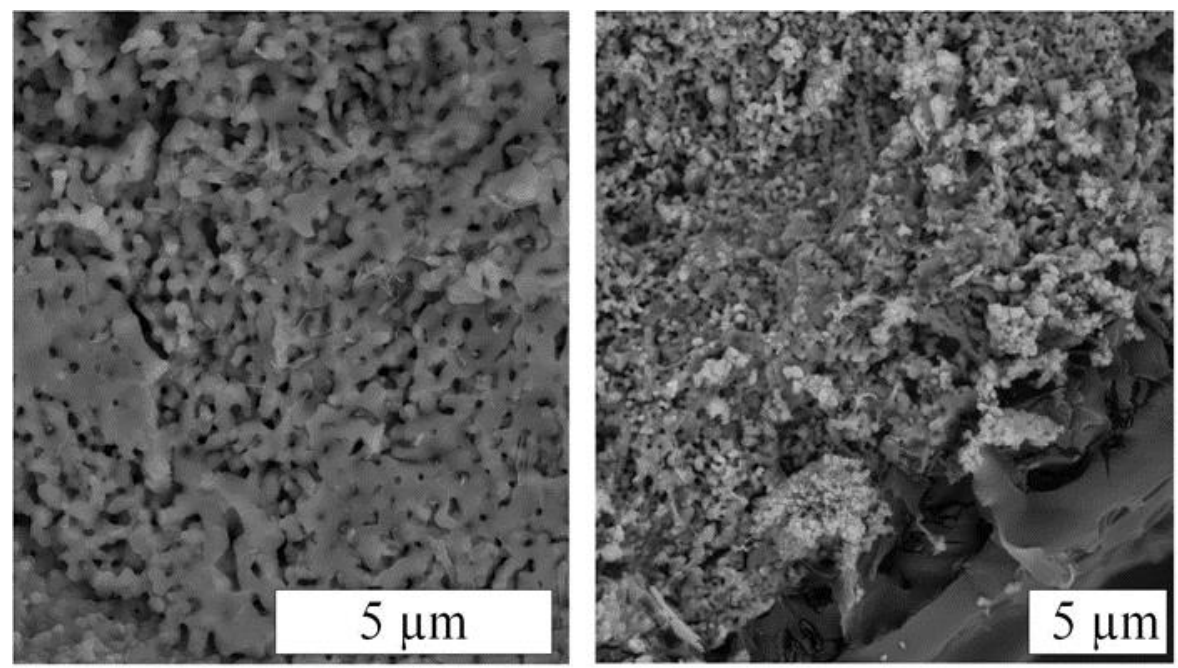

2.1. attēls. HAp/PLLA šķērsgriezums (SEM)

\subsubsection{CDHAp/PCL+cipro, CDHAp/PCL+genta, CDHAp/PLLA+cipro un CDHAp/PLLA+genta}

Kalcija deficìta hidroksiapatīta pulveri ieguva, izmantojot slapjās ķīmiskās nogulsnēšanas metodi. Tika izmantoti šādi reaǵenti: kalcija oksīds, iegūts no marmora (Sigma-Aldrich, UK), $\geq 97 \%$, ortofosforskābe (Sigma-Aldrich, UK) $\geq 85 \%$ un dejonizēts ūdens. Kompozīta veidošanas procesā tika izvērtēti vairāki faktori, piemēram, pH, suspensijas temperatūra un skābe (Sokolova et al., 2014).

PCL un CDHAp kompozīti ar biopolimēra sastāvu 20 wt\% un PLLA un CDHAp kompozīti ar biopolimēra sastāvu 30 wt\% tika sintezēti, izmantojot jaunu šķidro/cieto suspensiju tehnolog̣iju.

Gentamicīns 40 mg/ml koncentrācijā, bet ciprofloksacīns 100 mg/10 ml koncentrācijā tika izšks̄ịināts dejonizētā ūden̄i. Iegūtos šķīdumus sajauca ar dažādiem CDHAp/PCL un CDHAp/PLLA pulveriem. Iegūtos pulvera maisījumus žāvēja istabas temperatūrā 24 stundas. Izžāvētie kompozīti tika sapresēti tabletēs $(\mathrm{d}=12,5 \mathrm{~mm}, \mathrm{H}=2,2 \mathrm{~mm})$ (2.2. attēls). CDHAp/PCL un CDHAp/PLLA tablešu porainību noteica ar ǵeometrisko metodi.

Lai izvērtētu, vai PLLA un PCL piemīt antibakteriālas īpašības, tika pagatavoti CDHAp/PCL un CDHAp/PLLA paraugi bez antibiotiskām vielām. Katrai kompozītmateriālu grupai pret abu baktēriju kultūrām tika izgatavoti 8 paralēlie sērijas paraugi. Kompozītmateriālos ar antibiotiskajām vielām vidējais antibiotisko vielu daudzums sasniedza $30 \mathrm{mg}$ uz 0,5 g parauga. Paraugu vidējā masa bija 0,4 g.

Kalcija deficīta kompozītmateriāli pētîjumā tika iekḷauti, balstoties uz to, ka HAp/PLLA kompozītmateriāliem piemīt vājas kaulaudu atjaunošanas spējas, jo šūnas, kuras ir atbildīgas 
par kaulaudu atjaunošanos, nevar piesaistīties pie biomateriāla līdz PLLA pilnīgai biodegradācijai (Armentano et al., 2010).

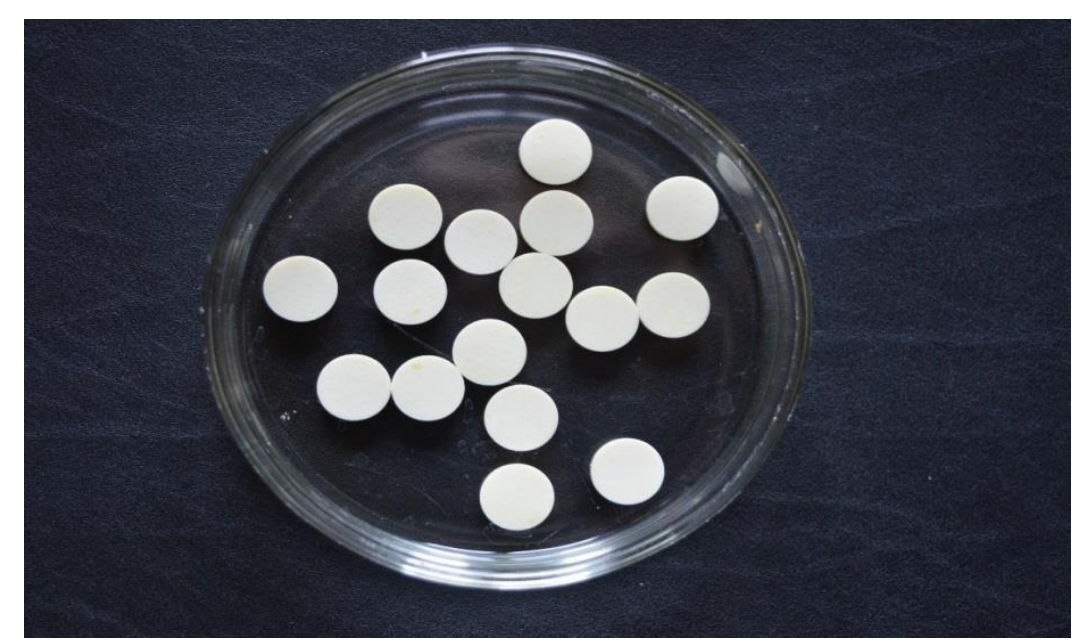

2.2. attēls. CDHAp/PLLA+cipro paraugi

\subsection{Antibakteriālo īpašību noteikšana in vitro}

\subsubsection{Antibakteriālo īpašību noteikšana baktēriju suspensijā}

Baktēriju suspensija tika pagatavota sterilos apstākḷos no $1 \mathrm{ml}$ TSB (Oxoid, UK) un $1 \mathrm{ml}$ baktēriju ar optisko blīvumu 0,5 pēc Makfārlenda (McFarland) standarta. Pirms biomateriālu paraugu ievietošanas baktēriju suspensijā tie visi - katrs atsevišķi - tika ievietoti $1 \mathrm{ml}$ truša plazmas (BBL, USA) un inkubēti termostatā (Memmert, Vācija) $37^{\circ} \mathrm{C}$ temperatūrā un $100 \%$ relatīvā mitrumā - divas stundas. Pēc divām stundām biomateriāla paraugi ar sterilas pincetes palīdzību tika pārvietoti uz mēgeni ar baktēriju suspensiju (2.3. attēls) un $24 \mathrm{~h}$ inkubēti $37{ }^{\circ} \mathrm{C}$. Baktēriju suspensija bez biomateriāla tika izmantota kā kontrole, lai salīdzinātu biomateriālu antibakteriālās īpašības, un arī $24 \mathrm{~h}$ tika inkubēta $37^{\circ} \mathrm{C}$. 


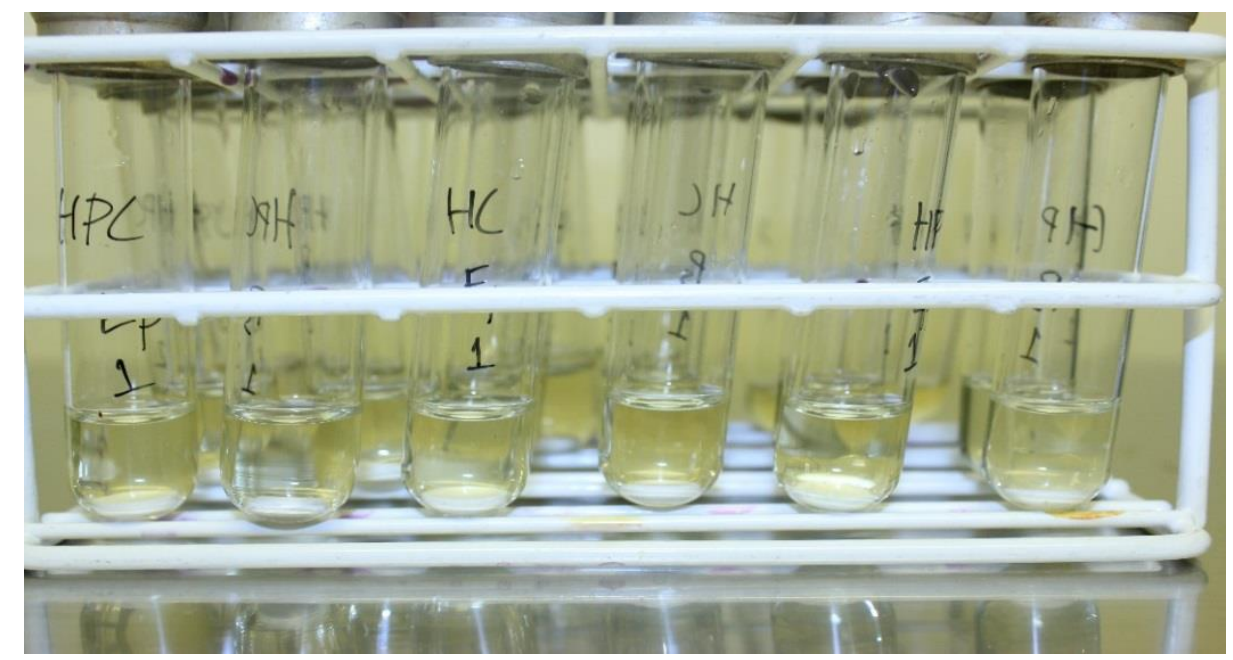

2.3. attēls. S. epidermidis suspensija ar HAp/PLLA+cipro

Pēc $24 \mathrm{~h}$ inkubācijas $0,1 \mathrm{ml}$ baktēriju suspensijas tika uzsēta uz TSA (Oxoid, UK), lai izvērtētu pētāmo biomateriālu antibakteriālās īpašības un efektivitāti. Tajā pašā laikā tika pagatavota jauna baktēriju suspensija un ar sterilas pincetes palīdzību pētāmo grupu biomateriāli tika pārvietoti jaunā TSB un baktēriju kultūru suspensijā uz nākamajām 24 h. Darbības tika atkārtotas katras 24 h, līdz izmeklējamo biomateriālu grupās divas dienas pēc kārtas vairs netika novērotas antibakteriālas īpašības, koloniju skaits uz TSA bija vienāds ar kontroles grupas koloniju skaitu uz TSA.

\subsubsection{Antibakteriālo īpašību noteikšana ar disku difūzijas metodi}

Kirby-Bauer disku difūzijas metode (2.4. attēls) ir standartizēta metode, ko izmanto mikrobiologiskajās laboratorijās, lai noteiktu baktēriju jutību pret antibiotiskajām vielām (Bauer et al., 1966). Atbilstoši EUCAST (EUCAST, 2015) standartiem tika pagatavota baktēriju suspensija ar optisko blīvumu 0,5 pēc Makfarlenda standarta ar Makfarlenda optisko densitometru (Biosan, Latvija). Pagatavotā baktēriju suspensija ar sterilu vates kociņu tika uzsēta uz sterilas TSA (Oxoid, $U K$ ) plates. Pēc baktēriju inokulācijas ar sterilu pinceti uz TSA tika novietoti biomateriālu diski un TSA barotne $24 \mathrm{~h}$ tika inkubēta termostatā $37{ }^{\circ} \mathrm{C}$ temperatūrā. Pēc $24 \mathrm{~h}$ tika analizētas biomateriālu paraugu antibakteriālās īpašības, izmērot sterilo zonu (diametru) ap biomateriālu diskiem. Pēc mērījumiem tika pagatavota jauna baktēriju suspensija, ko uzsēja uz jaunas, sterilas TSA barotnes, biomateriālu diskus pārnesa no vecās TSA barotnes uz jauno TSA barotni, un jauno barotni inkubēja vēl 24 h $37{ }^{\circ} \mathrm{C}$. Darbības tika atkārtotas ik pēc 24 h, līdz izmeklējamo biomateriālu grupās divas dienas pēc kārtas netika novērotas antibakteriālas īpašības jeb sterila zona ap biomateriālu paraugiem. 


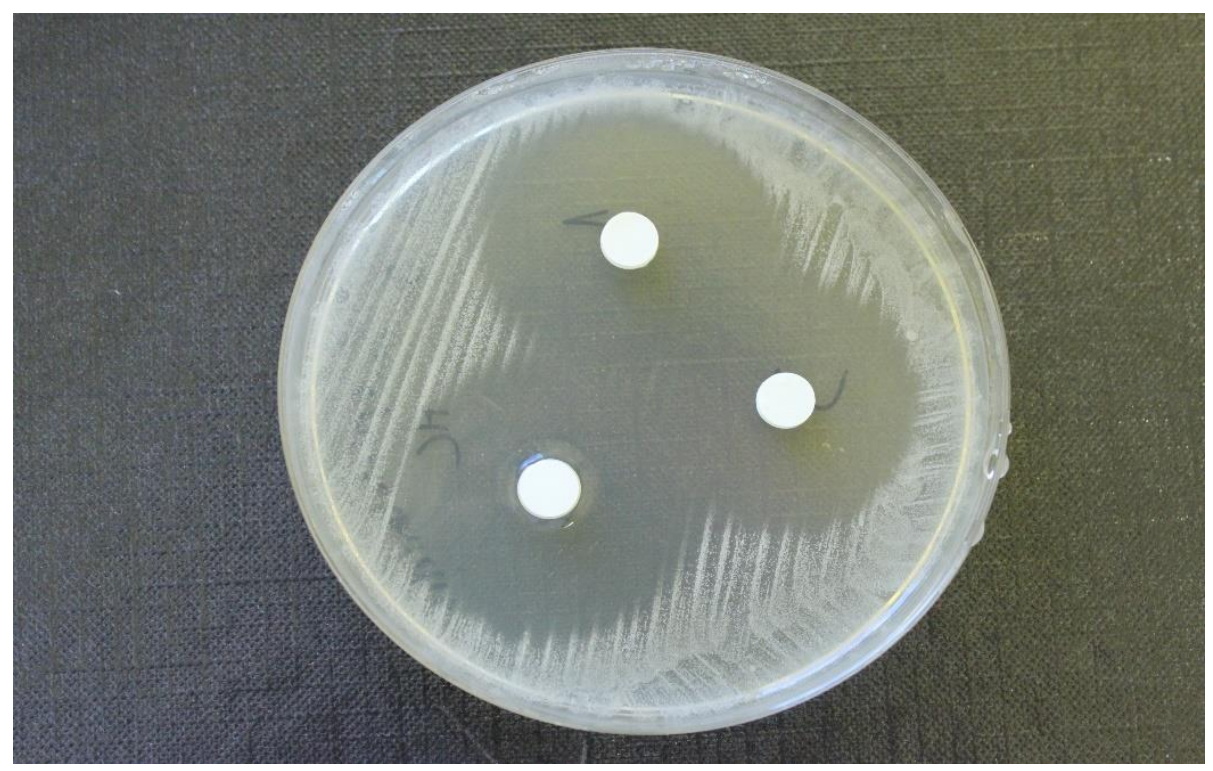

2.4. attēls. Disku difūzijas metode

\subsection{Izmeklējamās baktēriju kultūras un to jutība pret gentamicīnu un ciprofloksacīnu}

Visu biomateriālu antibakteriālās īpašības tika pêtītas, izmantojot S. epidermidis (ATCC 12228) un $P$. aeruginosa (ATCC 27853) baktēriju references kultūras.

Lai noteiktu baktēriju jutību pret antibiotiskajām vielām, tika izmantota antibiotisko stripu ražotāju ieteiktā procedūra. Uz Millera-Hintona (Mueller-Hinton) agara (Oxoid, UK) ar sterilu vates kociņu tika uzsētas baktērijas pēc 0,5 Makfarlenda standarta pagatavotas suspensijas. Pēc tam tika uzlikts gentamicīna vai ciprofloksacīna antibiotiskais strips (Liofilchem, Itālija). Agara plates inkubēja $37^{\circ} \mathrm{C}$ temperatūrā. Rezultātus izvērtēja pēc $24 \mathrm{~h}$ inkubācijas (1. pielikums).

\subsection{Iekaisuma intensitātes noteikšana in vivo}

\subsubsection{Eksperimentā izmantotie dzīvnieki}

Lai noteiktu iekaisuma citokīnu intensitāti audos ap implantēto biomateriālu, eksperimentā tika izmantoti trīs mēnešus veci trušu tēviņi. Visi izmantotie truši bija $3 \mathrm{~kg}$ smagi. Eksperimenta sākumā un gaitā neviens no trušiem neslimoja, tika ievēroti visi ētiskie aspekti un saņemta aţ̦auja no Valsts Pārtikas un veterinārā dienesta (2. pielikums). 


\subsubsection{Operācijas gaita}

Pirms operācijas tika pagatavotas $P$. aeruginosa un $S$. epidermidis baktēriju suspensijas ar optisko blīvumu 0,5 pēc Makfarlenda standarta. Trusim skausta rajonā tika noskūts apmatojums un veikta ādas apstrāde ar joda šķ̄īumu (2.5. attēls).

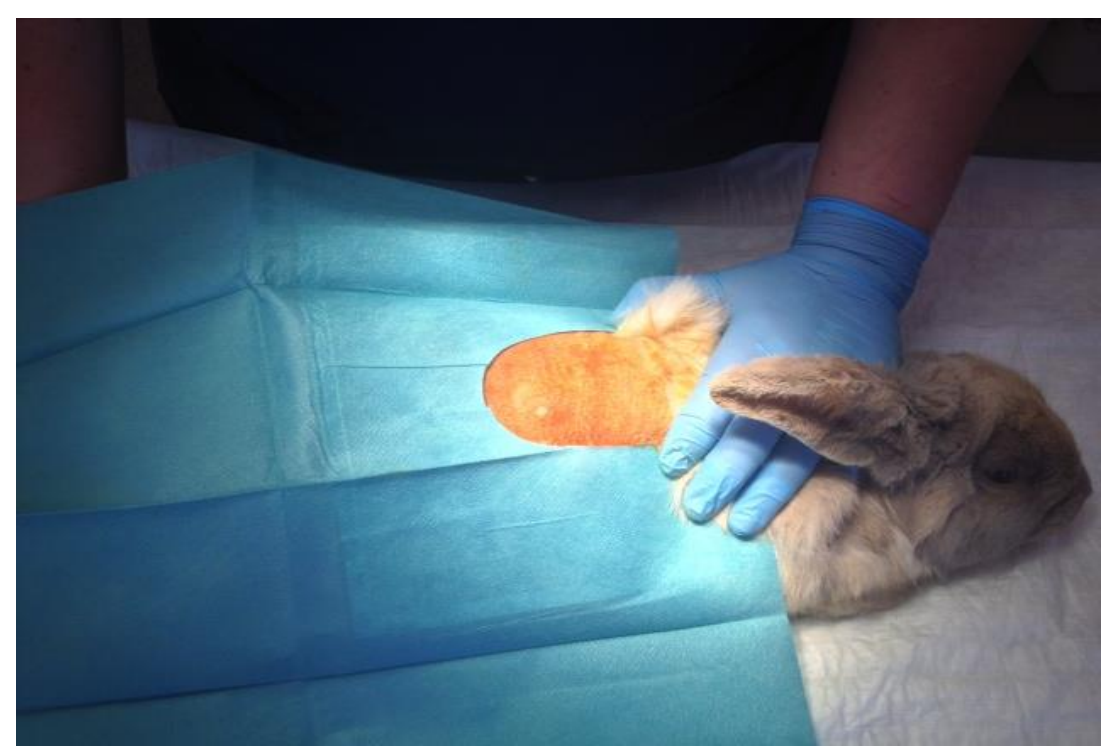

2.5. attēls. Truša sagatavošana pirms ādas incīzijas

Noskūtajā un ar antiseptiskajiem līdzekḷiem apstrādātajā skausta rajonā veica lokālu atsāpināšanu ar 2\% lidokaīna hidrohlorīda šķīdumu. Sterilos apstākḷıs, ar sterilu skalpeli veica ādas incīzija, izveidojot 2,5 cm lielu brūci. Pakāpeniski ar skalpeļa palīdzību izveidoja pietiekami lielu zemādas kabatu, kurā varētu implantēt biomateriāla tableti (2.6. attēls).

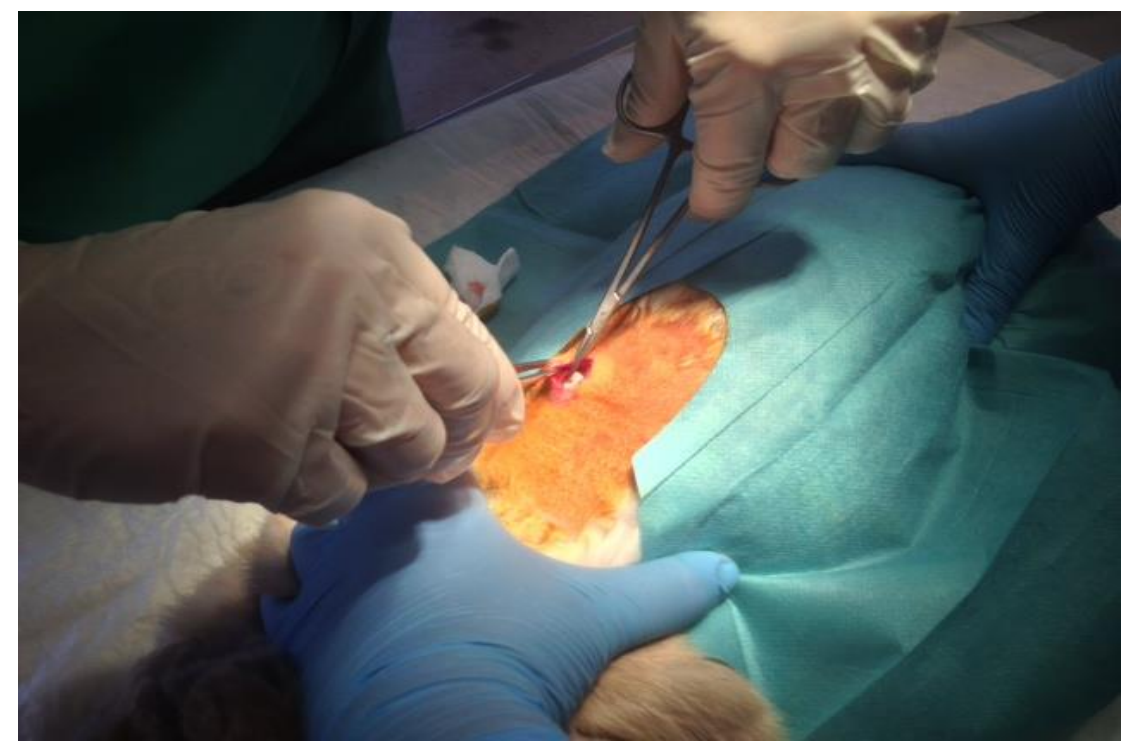

2.6. attēls. Zemādas kabata ar biomateriāla disku 
Pēc biomateriāla ievietošanas zemādas kabatā brūce tika inficēta ar 0,1 ml baktēriju suspensiju (2.7. attēls).

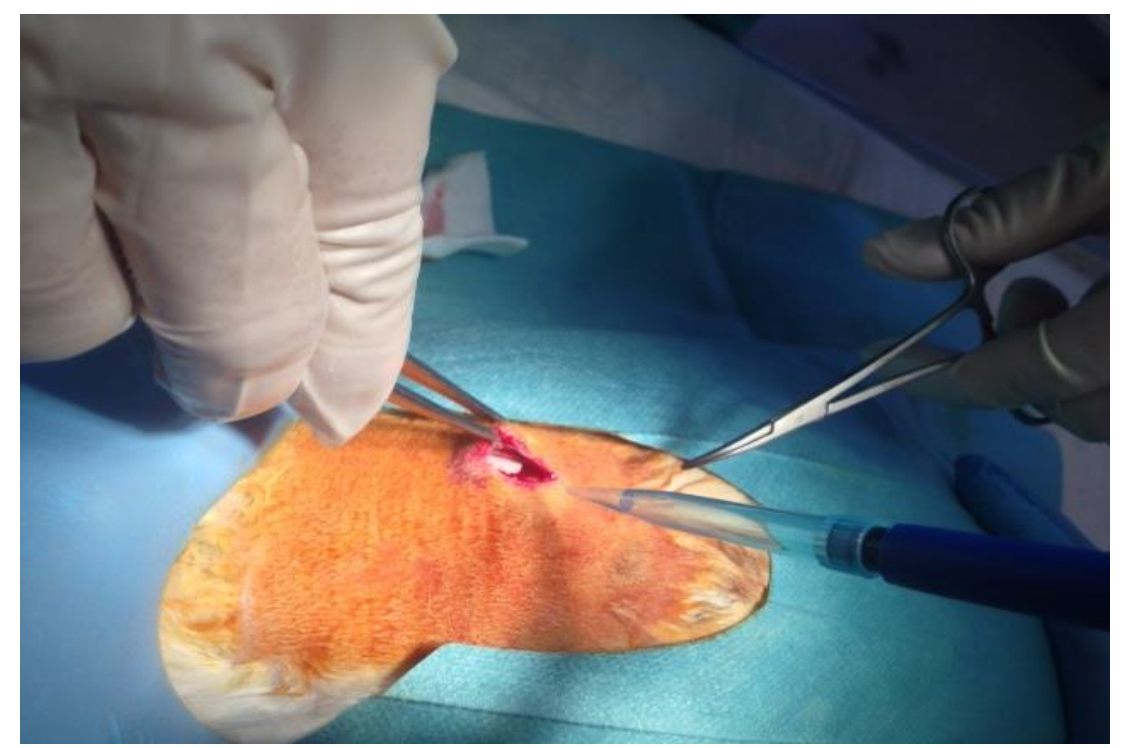

2.7. attēls. Brūces inficēšana ar baktēriju suspensiju

Pēc brūces inficēšanas ar baktēriju suspensiju brūce tika aizšūta ar steriliem diegiem (2.8. attēls). Tika uzliktas 3 līdz 4 šuves, cieši noslēdzot brūci.

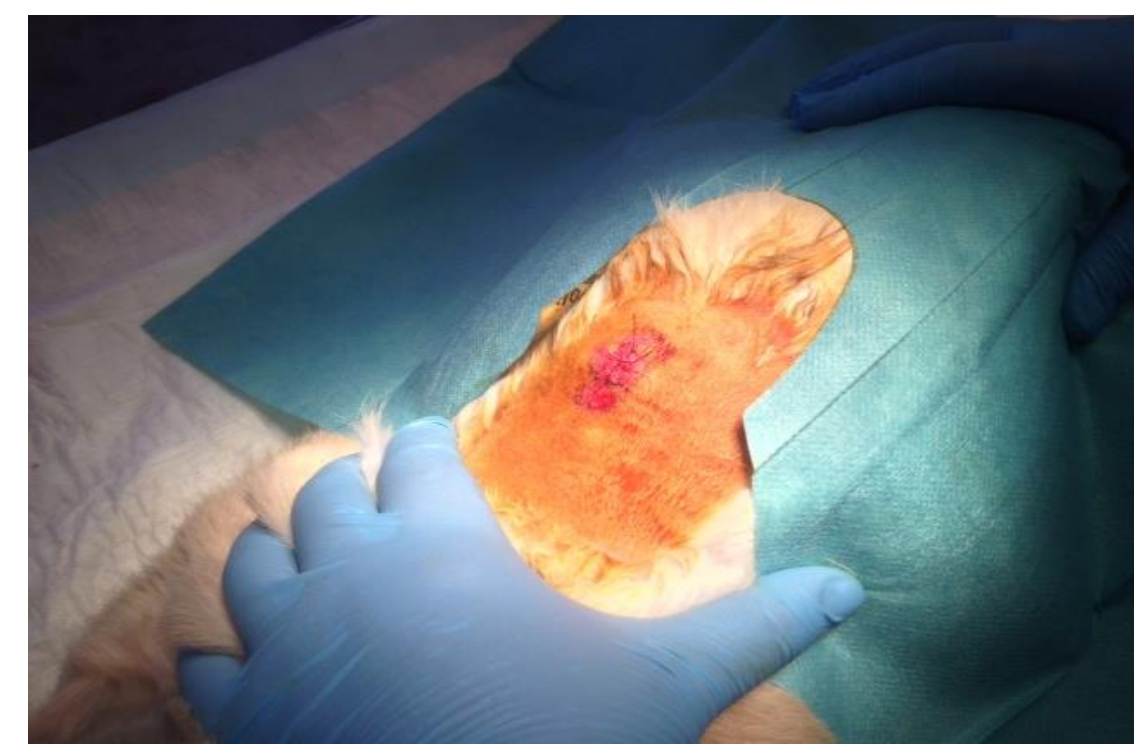

2.8. attēls. Brūces aizšǔšana

Pēcoperācijas periods pagāja bez komplikācijām, eksperimenta laikā neviens trusis neslimoja un neaizgāja bojā. Biomateriālu paraugi tika izņemti pēc 4 nedēlāam, kas ir vislabākais laiks iekaisuma zonas izvērtēšanai ap biomateriālu un distancēti no tā, jo ilgākā laika periodā iekaisuma process var izsīkt. Savukārt par 4 nedēḷām īsākā laika periodā ir grūti 
izvērtēt, vai iekaisuma reakcija ir no biomateriāla kontaminācijas vai tā ir normāla organisma imūnā atbilde pret ķirurğisko iejaukšanaos.

Tika implantēti HAp/PLLA+cipro, HAp+cipro, HAp/PLLA, HAp/PLLA+genta un HAp+genta, kas bija inficēti ar P. aeruginosa vai S. epidermidis (2.1. tabula).

2.1. tabula

In vivo pētijumā izmantoto paraugu grupas

\begin{tabular}{|l|c|c|c|c|c|c|}
\hline $\begin{array}{l}\text { Paraugu } \\
\text { grupa }\end{array}$ & HAp & PLLA & Ciprofloksacīns & Gentamicīns & P. aeruginosa & S. epidermidis \\
\hline A grupa & $\mathrm{X}$ & $\mathrm{X}$ & $\mathrm{X}$ & & $\mathrm{X}$ & \\
\hline B grupa & $\mathrm{X}$ & $\mathrm{X}$ & $\mathrm{X}$ & & & $\mathrm{X}$ \\
\hline C grupa & $\mathrm{X}$ & $\mathrm{X}$ & & $\mathrm{X}$ & $\mathrm{X}$ & \\
\hline D grupa & $\mathrm{X}$ & $\mathrm{X}$ & & $\mathrm{X}$ & & $\mathrm{X}$ \\
\hline E grupa & $\mathrm{X}$ & & $\mathrm{X}$ & & $\mathrm{X}$ & \\
\hline F grupa & $\mathrm{X}$ & & $\mathrm{X}$ & & & $\mathrm{X}$ \\
\hline G grupa & $\mathrm{X}$ & & & $\mathrm{X}$ & $\mathrm{X}$ & \\
\hline H grupa & $\mathrm{X}$ & & & $\mathrm{X}$ & & $\mathrm{X}$ \\
\hline I grupa & $\mathrm{X}$ & $\mathrm{X}$ & & & $\mathrm{X}$ & \\
\hline J grupa & $\mathrm{X}$ & $\mathrm{X}$ & & & & $\mathrm{X}$ \\
\hline
\end{tabular}

\subsubsection{Izmeklējamais materiāls}

Lai noteiktu IL-10, TNF- $\alpha$ un beta-defensīna-2 līmeni apkārtējos audos ap implantēto biomateriālu, tika izmantota standartizētā ELISA metode ar ELISA komplektiem (USCN life science un MyBioSource, USA). Četras nedēḷas pēc biomateriālu implantācijas truši tika eitanizēti. Ar sterilu skalpeli tika pārgriezta dzīvnieka āda implantētā biomateriāla vietā. Tika savākti vienāda lieluma audu paraugi: trīs audu paraugi no tieši pieguļošiem audiem ap biomateriālu, trīs audu paraugi - no ārējās zonas ap biomateriālu un trīs audu paraugi distancēti $(1,5 \mathrm{~cm})$ no implantētā biomateriāla vietas. Audus pirms homogenizācijas noskaloja ar aukstu PBS (0,01 mol/1, pH 7,0-7,2), lai noskalotu asiņu atlikumus no audiem. Audi tika sagriezti smalkākos gabaliņos un homogenizēti. Iegūto audu suspensiju ievietoja ultraskaņas vannā, lai pārplēstu šūnu membrānas, pēc tam to centrifugēja 5 minūtes ar 5000 apgriezieniem minūtē. Pēc ELISA standartazētas procedūras 96 iedobīšu mikroplati analizēja ar ELISA lasītāju spektrofotometriski, viļ̣na garums $450 \mathrm{~nm} \pm 10 \mathrm{~nm}$ (TECAN, Šveice).

\subsection{Statistiskās metodes}

Iegūto rezultātu izvērtēšanai tika izvēlētas neparametriskās statistiskās metodes. Tika izmantots Manna-Vitnija tests (Mann et al., 1947), lai izvērtētu, vai ir statistiski ticamas atšķirības starp pētījumā izmantoto biomateriālu grupu antibakteriālo ilgumu. Par statistiski 
ticamu tika pieņemts, ja $p$ vērtība ir mazāka vai vienāda ar 0,05 . Rezultāti tika ievadīti Microsoft Excel 2014, un statistiskā analīze tika veikta ar SPSS 22.0 (statistical package for the social sciences).

\subsection{Izmantotās literatūras meklēšana}

Pētījumā izmantotā literatūra tika meklēta, izmantojot tiešsaistē pieejamās zinātniskās datubāzes:

- Pubmed

- Scopus

- Science Direct

- ProQuest

- $E B S C O$

- Wiley Online

- Access Medicine

- ClinicalKey

- BMJ Journals

Zinātniskajās tiešsaistes datubāzās zinātniskā literatūra tika meklēta, izmantojot atsevišķus atslēgvārdus un nepieciešamības gadījumos savienotājvārdus AND (un), OR (vai) un NOT (nē, noliegums).

Izmantotie atslēgvārdi:

- Biomaterials

- Biomaterial associated infections

- S. epidermidis

- P. aeruginosa

- Bacteria

- Gentamicin

- Ciprofloxacin

- Antibiotics

- Polylactic acid

- Polycaprolactone

- Polymers

- Biodegradable

- Antimicrobial peptides

- IL-10 
- Beta defensin

- Tumor necrosis factor alfa

- Inflammation

- Cytokines

- Hydroxyapatite

- In vivo

- In vitro

- Antibacterial

- Biofilms 


\section{REZULTĀTI}

\subsection{Antibiotisko vielu minimāli inhibējošā koncentrācija}

Izmantojot standartizēto E-testu metodi, tika noskaidrots, ka pētījumā izmantotās kultūras $P$. aeruginosa un S. epidermidis ir jutīgas pret pêtījumā izmantotajām antibiotiskajām vielām. Ciprofloksacīna MIC pret S. epidermidis ir $0,094 \mu \mathrm{g} / \mathrm{ml}$, pret $P$. aeruginosa $0,125 \mu \mathrm{g} / \mathrm{ml}$. Savukārt gentamicīna MIC pret $S$. epidermidis ir $0,19 \mu \mathrm{g} / \mathrm{ml}$, pret P. aeruginosa $-1,0 \mu \mathrm{g} / \mathrm{ml}$.

\subsection{HAp/PLLA+genta un HAp/PLLA+cipro antibakteriālā efektivitāte in vitro}

Izmantojot antibakteriālo īpašību noteikšanas metodi baktēriju suspensijāa, ir redzams, ka HAp/PLLA+genta biomateriālu maksimālais antibakteriālās darb̄̄bas ilgums pret S. epidermidis ir $264 \mathrm{~h}$, bet minimālais antibakteriālais ilgums - $216 \mathrm{~h}$, tādējādi vidējais antibakteriālais ilgums pret $S$. epidermidis ir 249,6 $\pm 16,78 \mathrm{~h}$ (3.1. attēls).

HAp/PLLA biomateriālam antibakteriālās īpašības netika novērotas ne pret vienu no baktēriju kultūrām.

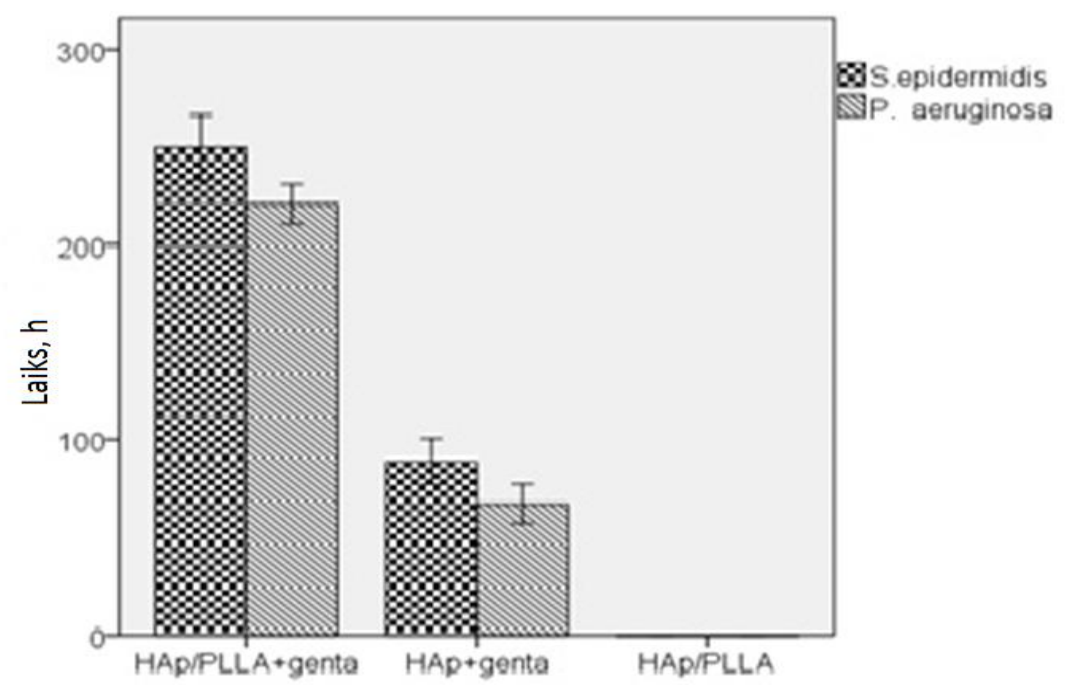

\section{1. attēls. Vidējais antibakteriālais ilgums dažādiem kompoz̄itmateriāliem ar gentamicīnu}

Biomateriāliem bez PLLA polimēra (HAp+genta) antibakteriālais ilgums ir ievērojami mazāks, to maksimālais antibakteriālais ilgums pret $S$. epidermidis ir 96 h, bet minimālais antibakteriālais ilgums ir $72 \mathrm{~h}$, vidējais antibakteriālais ilgums ir 88,8 $\pm 11,59 \mathrm{~h}$. Izmantojot 
Manna-Vitnija testu, ir redzams, ka biomateriāliem ar PLLA un gentamicīnu ir statistiski ticami lielāks antibakteriālais ilgums pret $S$. epidermidis nekā biomateriāliem bez PLLA $(\mathrm{p}<0,001)$.

HAp/PLLA+genta un HAp+genta spēja inhibēt S. epidermidis augšanu in vitro kopumā ir atšksirīga (3.2.attēls), bet vienāda pirmajās trīs eksperimenta dienās, kad gandrīz visas S. epidermidis baktērijas tika inhibētas. Nākamajās eksperimenta dienās HAp/PLLA+genta saglabāja augstas $S$. epidermidis augšanas inhibīcijas spējas un zaudēja tās pakāpeniski, bet HAp+genta S. epidermidis augšanas inhibīcijas spējas zaudēja strauji.

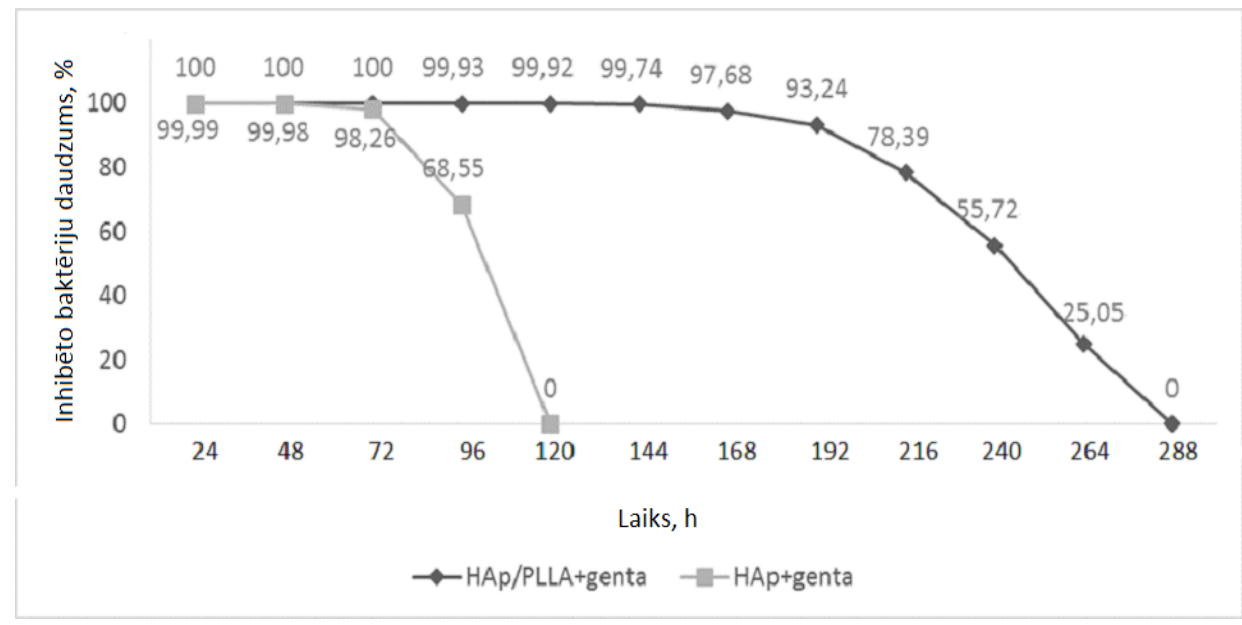

3.2. attēls. S. epidermidis augšanas inhibīcijas dinamika

Manna-Vitnija tests parādīja, ka starp HAp/PLLA+genta un HAp+genta biomateriālu grupām pret $P$. aeruginosa ir statistiski ticama atšksirība $(\mathrm{p}<0,001)$, un šo grupu maksimālais un vidējais antibakteriālais ilgums ir mazāks nekā pret S. epidermidis. Maksimālais HAp/PLLA+genta antibakteriālais ilgums pret $P$. aeruginosa ir $240 \mathrm{~h}$, bet minimālais antibakteriālais ilgums - $216 \mathrm{~h}$, kas ir vienāds arī pret S. epidermidis. HAp+genta maksimālais antibakteriālais ilgums pret $P$. aeruginosa ir 72 h, minimālais antibakteriālais ilgums $-48 \mathrm{~h}$. Attiecīgi vidējais HAp/PLLA+genta antibakteriālais laiks pret $P$. aeruginosa ir $220,8 \pm 10,11 \mathrm{~h}$, bet HAp+genta $-67,2 \pm 10,11 \mathrm{~h}$.

HAp+genta un HAp/PLLA+genta $P$. aeruginosa augšanas inhibīcijas dinamika pirmajās 48 h statistiski ticami neatšķiras ( $\mathrm{p}>0,05)$, bet, sākot ar trešo eksperimenta dienu, novēroja statistiski ticamas atšķirības $(\mathrm{p}<0,001)$ starp HAp/PLLA+genta un HAp+genta biomateriāliem pret $P$. aeruginosa. Līdzīgi kā $S$. epidermidis gadījumā, HAp/PLLA+genta biomateriāliem pret $P$. aeruginosa novēroja pakāpenisku antibakteriālo īpašību zudumu (3.3. attēls). 


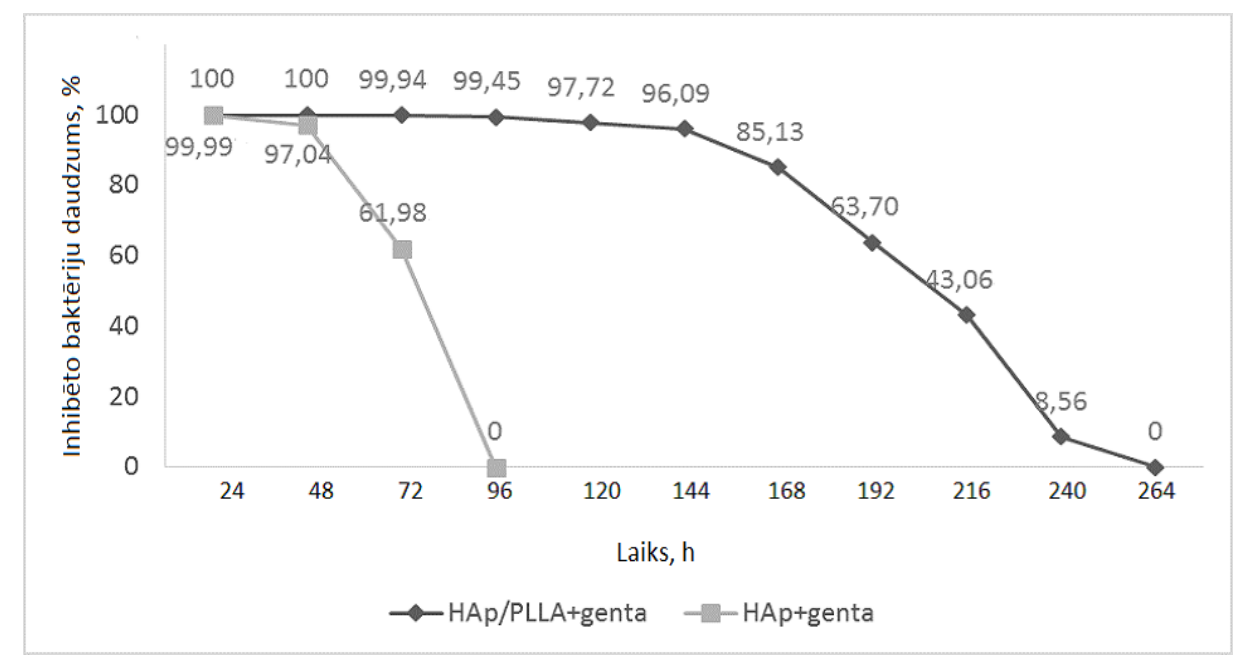

3.3. attēls. $P$. aeruginosa augšanas inhibīcijas dinamika

Līdzīgas tendences pret abām pētījumā izmantotajām baktēriju kultūrām ir gan HAp/PLLA+cipro un HAp+cipro biomateriāliem, ganr HAp/PLLA+genta un HAp+genta gadījumā. HAp/PLLA+cipro maksimālais antibakteriālais laiks pret S. epidermidis bija 288 h, minimālais antibakteriālais laiks - 264 h. Savukārt HAp+cipro maksimālais un minimālais antibakteriālais laiks pret $S$. epidermidis bija līdzīgs kā HAp+genta un sasniedza attiecīgi $96 \mathrm{~h}$ un 72 h. Tādējādi vidējais antibakteriālais laiks biomateriāliem ar PLLA ir ilgāks nekā biomateriāliem bez PLLA (3.4. attēls).

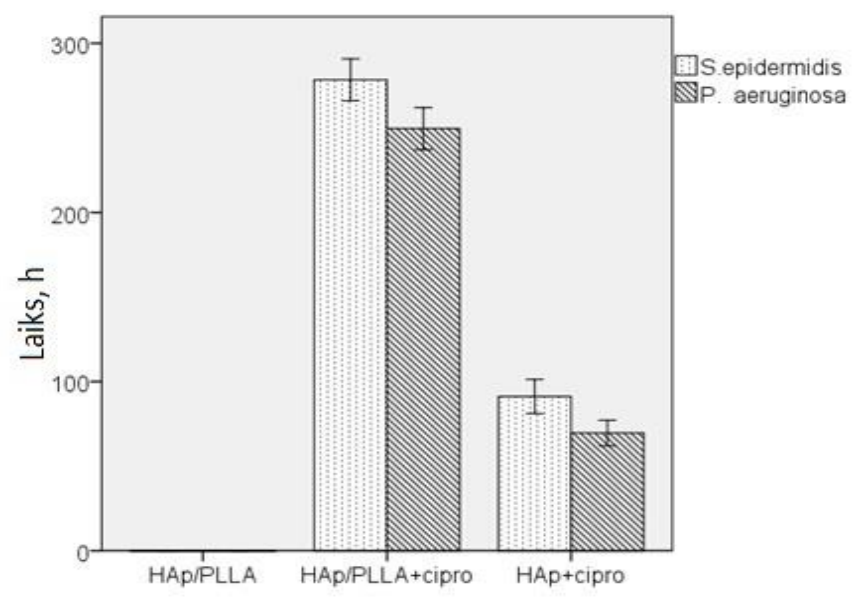

3.4. attēls. Vidējais antibakteriālais laiks dažādiem kompozītmateriāliem ar ciprofloksacīnu

Vidējais HAp/PLLA+cipro antibakteriālais laiks pret $P$. aeruginosa ir īsāks nekā pret $S$. epidermidis. Starp HAp/PLLA+cipro un HAp+cipro pret $P$. aeruginosa tika novērota statistiski ticama atšksirìba $(\mathrm{p}<0,001)$. 


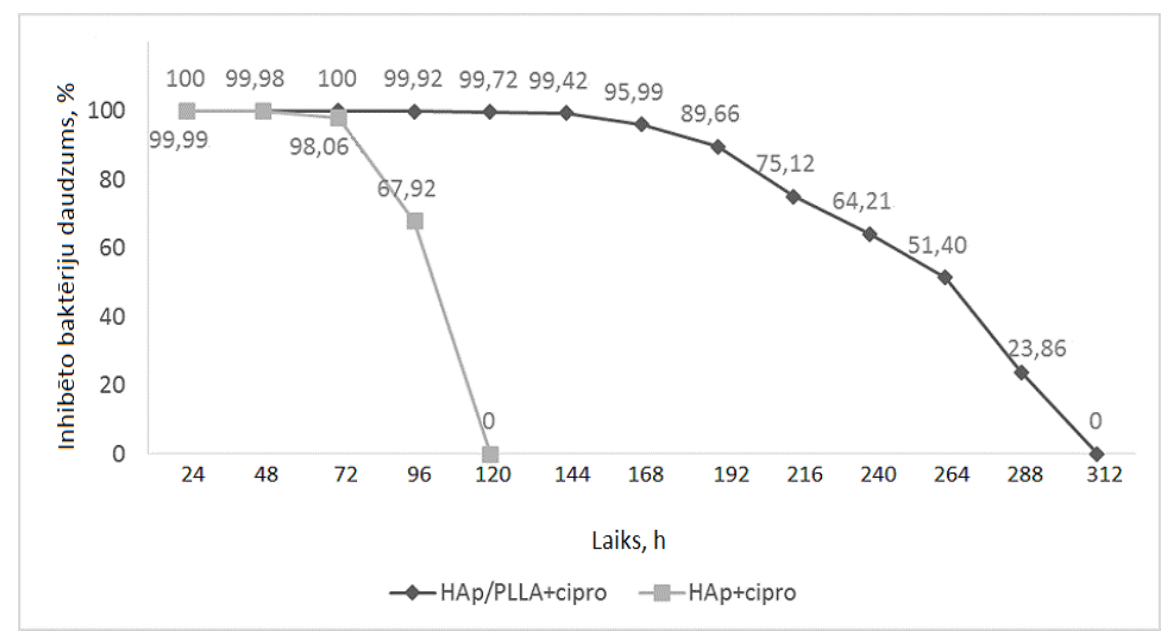

3.5. attēls. S. epidermidis augšanas inhibīcijas dinamika

HAp/PLLA+cipro un HAp+cipro pilnībā inhibē S. epidermidis augšanu (3.5.attēls.), kas pirmajās trijās eksperimenta dienās statistiski ticami neatšķiras ( $\mathrm{p}>0,05)$, bet, sākot ar ceturto eksperimenta dienu - 96 stundu laika atzīmē, novēro statistiski ticamas ( $<$ 0,005) atšķirības. Savukārt $P$. areruginosa augšanas inhibīcijas dinamikā (3.6. attēls) novēroja statistiski ticamas atšķirības $(\mathrm{p}<0,05)$ jau eksperimenta $72 \mathrm{~h}$ atzīmē.

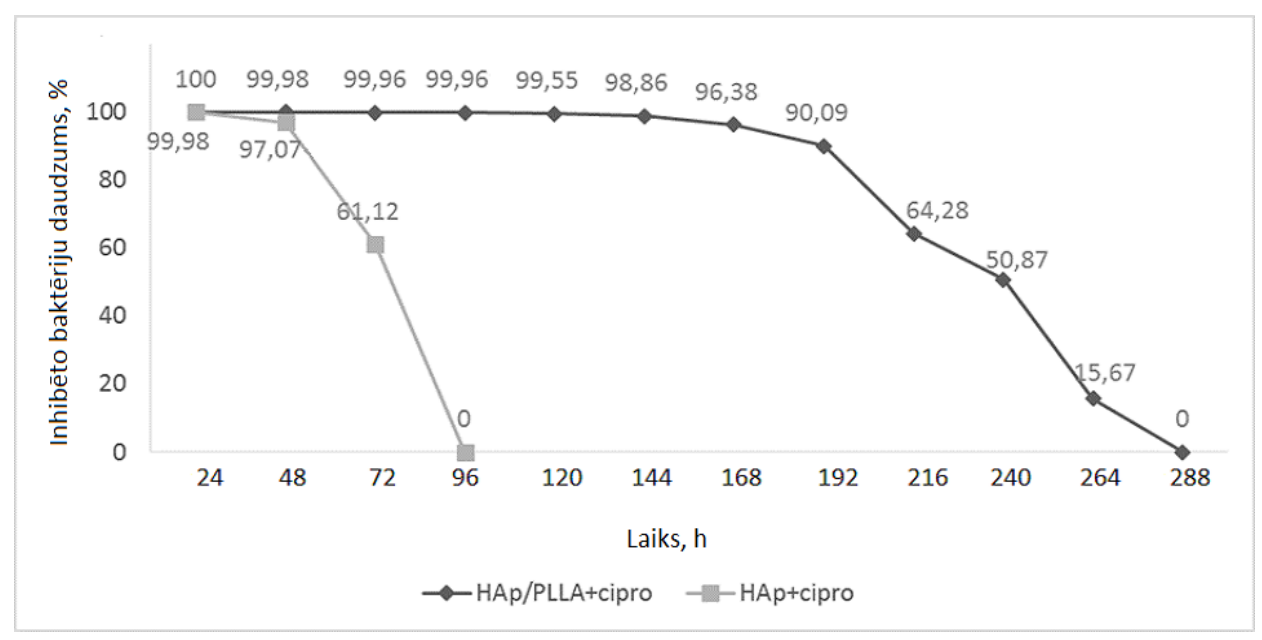

3.6. attēls. $P$. aeruginosa augšanas inhibīcijas dinamika

Izmantojot Manna-Vitnija testu, var secināt, ka biomateriāli - HAp/PLLA+genta, HAp+genta, HAp/PLLA+cipro un HAp+cipro - nevienai no baktēriju kultūrām statistiski ticami nemaina $(\mathrm{p}>0,05)$ inhibēto baktēriju procentuālo daudzumu laika posmā no $24 \mathrm{~h}$ līdz 48 h.

Nosakot HAp/PLLA+cipro un HAp+cipro antibakteriālās īpašības pret abām baktēriju kultūrām ar disku difūzijas metodi, redzams, ka antibakteriālās izmeklēšanas metode neietekmē biomateriālu paraugu antibakteriālo laiku ne pret vienu no pētījumā izmantojamām baktēriju kultūrām. Tāpat neatšķiras arī S. epidermidis augšanas inhibīcija (3.7. attēls), jo 
HAp/PLLA+cipro savas antibakteriālās īpašības saglabā ilgu laika periodu un tās zaudē pakāpeniski, bet HAp+cipro savas antibakteriālās īpašības zaudē ḷoti strauji, un 5 dienu laikā tās līdzinās nullei. Izmantojot disku difūzijas metodi, redzams, ka HAp+cipro biomateriāli izdala lielāku antibiotisko vielu koncentrāciju nekā HAp/PLLA+cipro, jo pirmajās eksperimenta dienās ir novērojams lielāks sterilās zonas diametrs, kas liecina par lielāku antibiotisko vielu difundēšanu no biomateriāla parauga. HAp+cipro ar̄̄ pret $P$. aeruginosa izdala lielāku antibiotisko vielu daudzumu, jo sterilās zonas diametrs ir lielāks nekā HAp/PLLA+cipro (3.8. attēls).

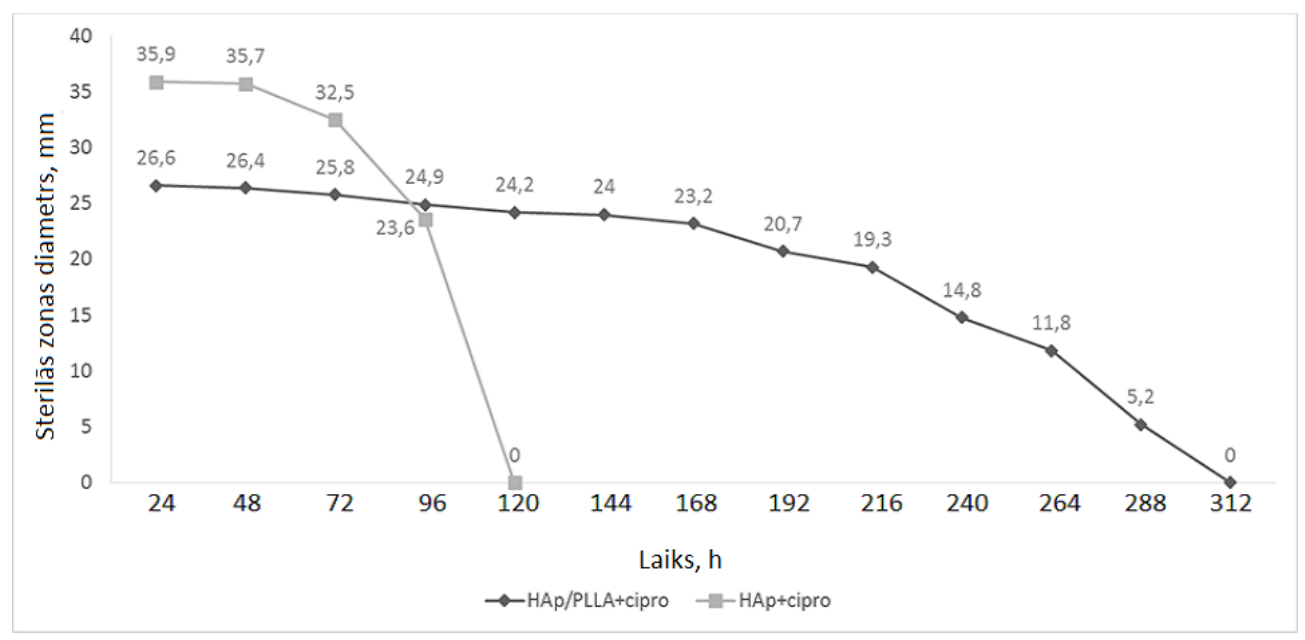

3.7. attēls. S. epidermidis augšanas inhibīcijas dinamika

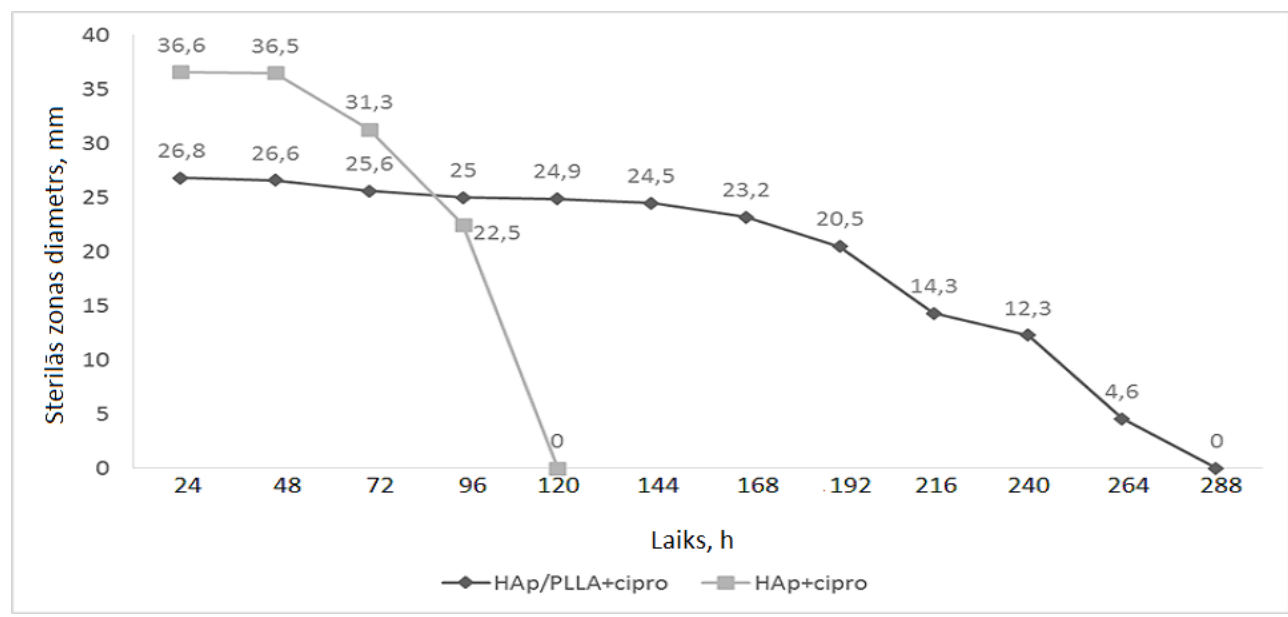

3.8. attēls. $P$. aeruginosa augšanas inhibīcijas dinamika

Taču HAp/PLLA+cipro kopējais antibakteriālais laiks pret $P$. aeruginosa ir ilgāks nekā HAp+cipro, un tā antibakteriālās īpašības tika zaudētas pakāpeniski visa in vitro pētījuma laikā. 
Biomateriāliem ar zemāku porainību - $\downarrow$ HAp/PLLA+cipro - statistiski ticami $(\mathrm{p}<0,001)$ atšķiras antibakteriālais laiks, salīdzinot ar biomateriāliem, kuriem ir augstāka porainība, - Hap/PLLA+cipro. Statistiski ticamas atšksirības $(\mathrm{p}<0,001)$ novēroja arī dažāda porainības līmeņa biomateriāliem bez PLLA ar antibiotiskām vielām (3.9. attēls).

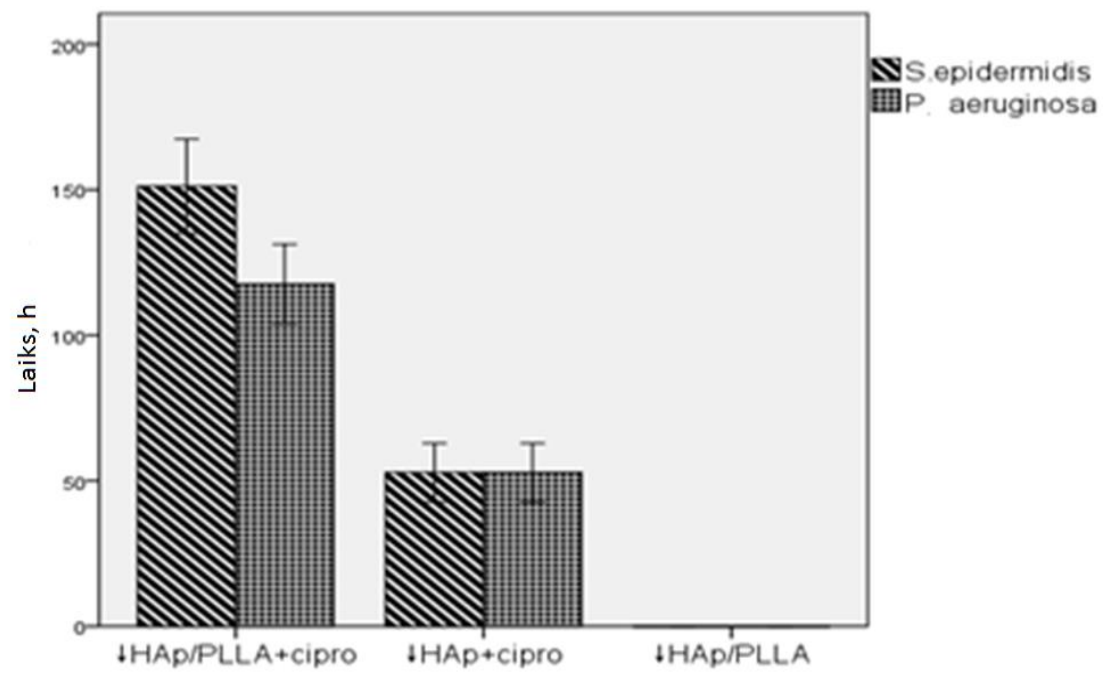

3.9. attēls. Vidējais antibakteriālais laiks kompozītmateriāliem ar samazinātu porainību un ciprofloksacīnu

Zemākas porain̄ības biomateriāliem novēroja $S$. epidermidis augšanas inhibīcijas dinamikas (3.10. attēls) izmaiṇas, salīdzinot ar augstākas porainības līmeņa biomateriāliem (3.11. attēls un 3.12. attēls).

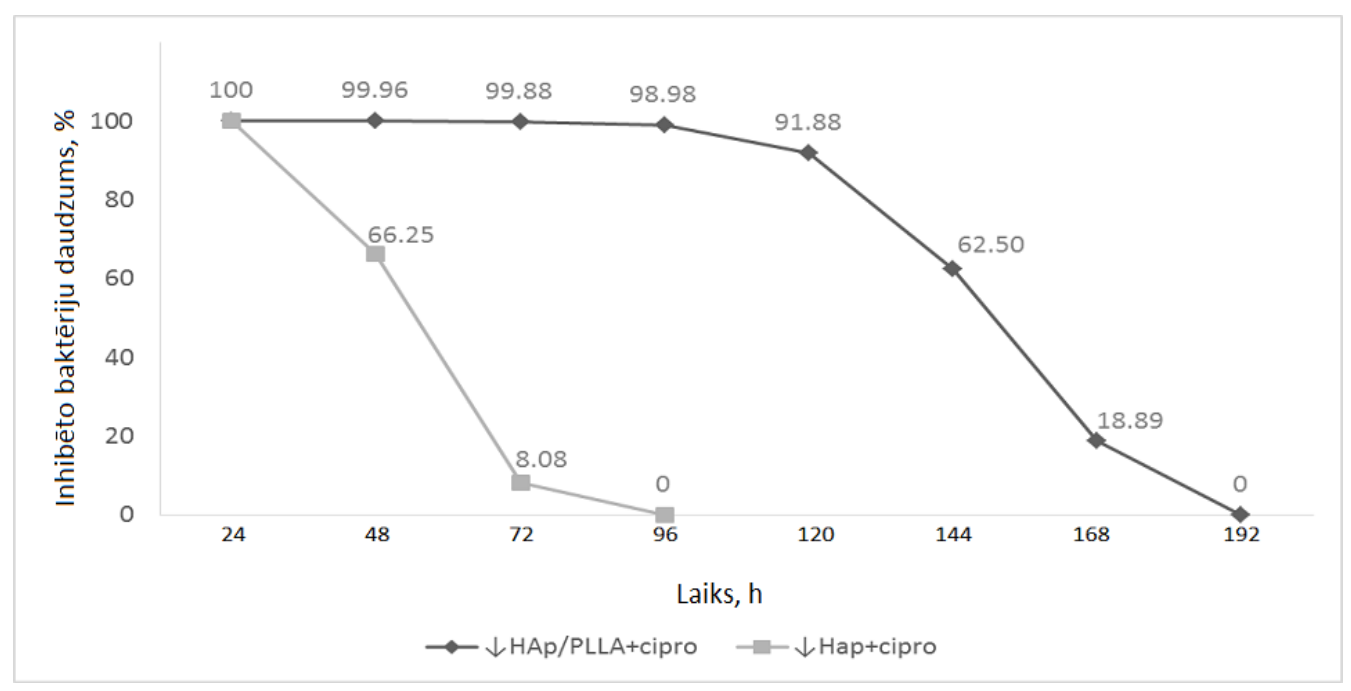

3.10. attēls. $S$. epidermidis augšanas inhibīcijas dinamika 


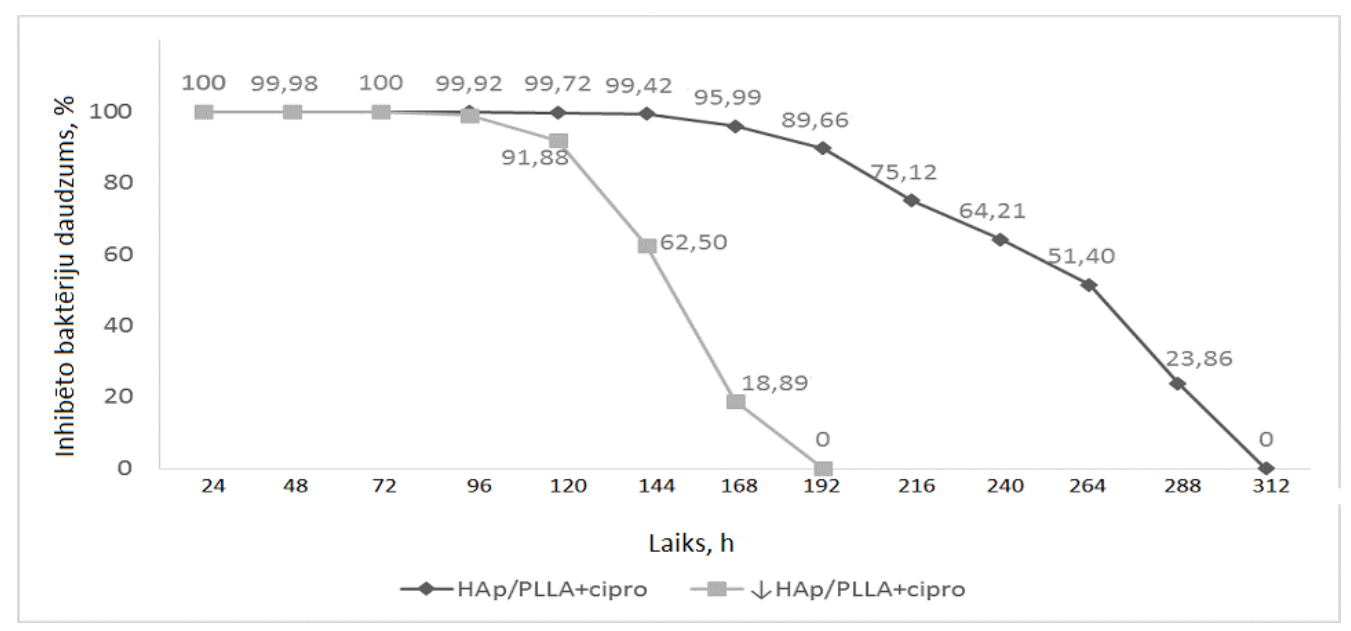

3.11. attēls. S. epidermidis augšanas inhibīcijas dinamika dažādas porain̄̄bas biomateriāliem

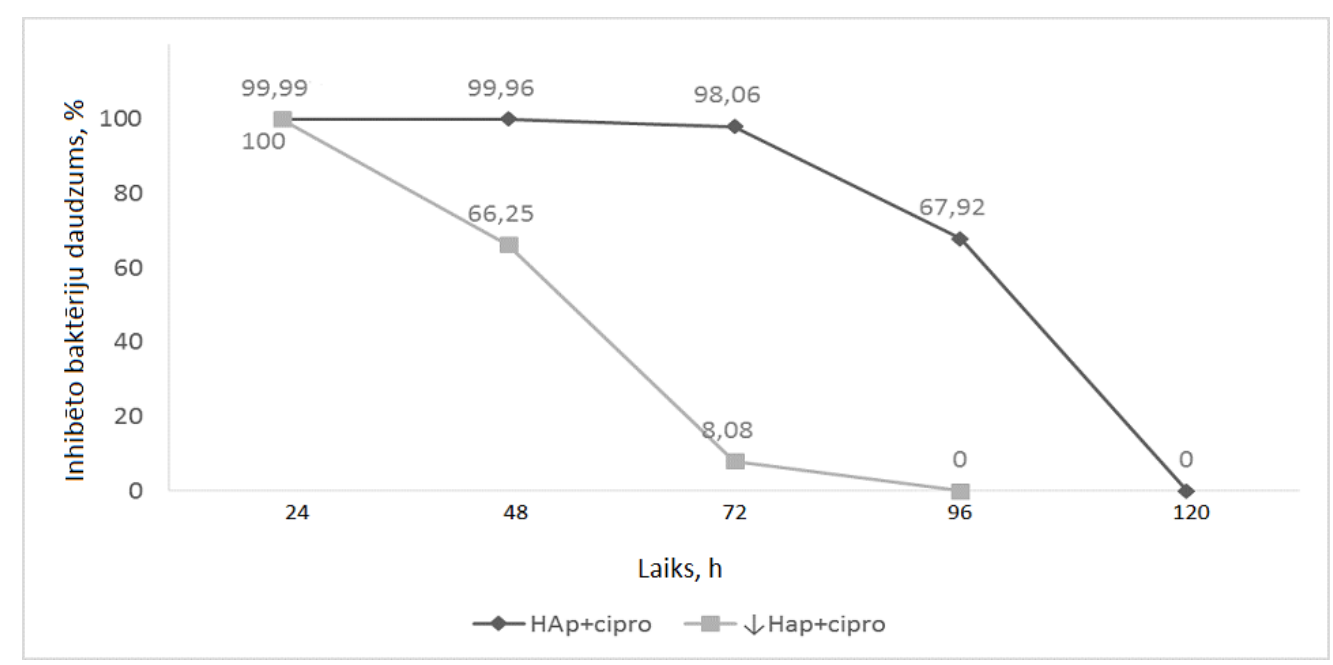

3.12. attēls. S. epidermidis augšanas inhibīcijas dinamika dažādas porainības biomateriāliem bez polimēra

$\downarrow$ HAp+cipro S. epidermidis augšanas inhibīcijas spējas ir mazākas nekā HAp+cipro biomateriāliem ar augstāku porainību, kas liecina, ka no porainības līmeņa ir atkarīga biomateriālu spēja inhibēt baktēriju augšanu. Biomateriāliem ar PLLA spēja inhibēt S. epidermidis augšanu arī ir atkarīga no porainības līmeņa, ņemot vērā, ka HAp/PLLA+cipro antibakteriālais laiks ir ilgāks nekā $\downarrow$ HAp/PLLA+cipro.

Porain̄ibas līmeņa ietekmi uz antibakteriālo laiku pierāda arī pētījums ar $P$. aeruginosa (3.13. attēls) baktēriju kultūru, kurā redzams, ka zemākas porain̄̄bas biomateriāliem piemīt 1̄slaicīga $P$. aeruginosa augšanas inhibīcijas dinamika, salīdzinot ar augstākas porainības biomateriāliem (3.14. attēls un 3.15. attēls). 


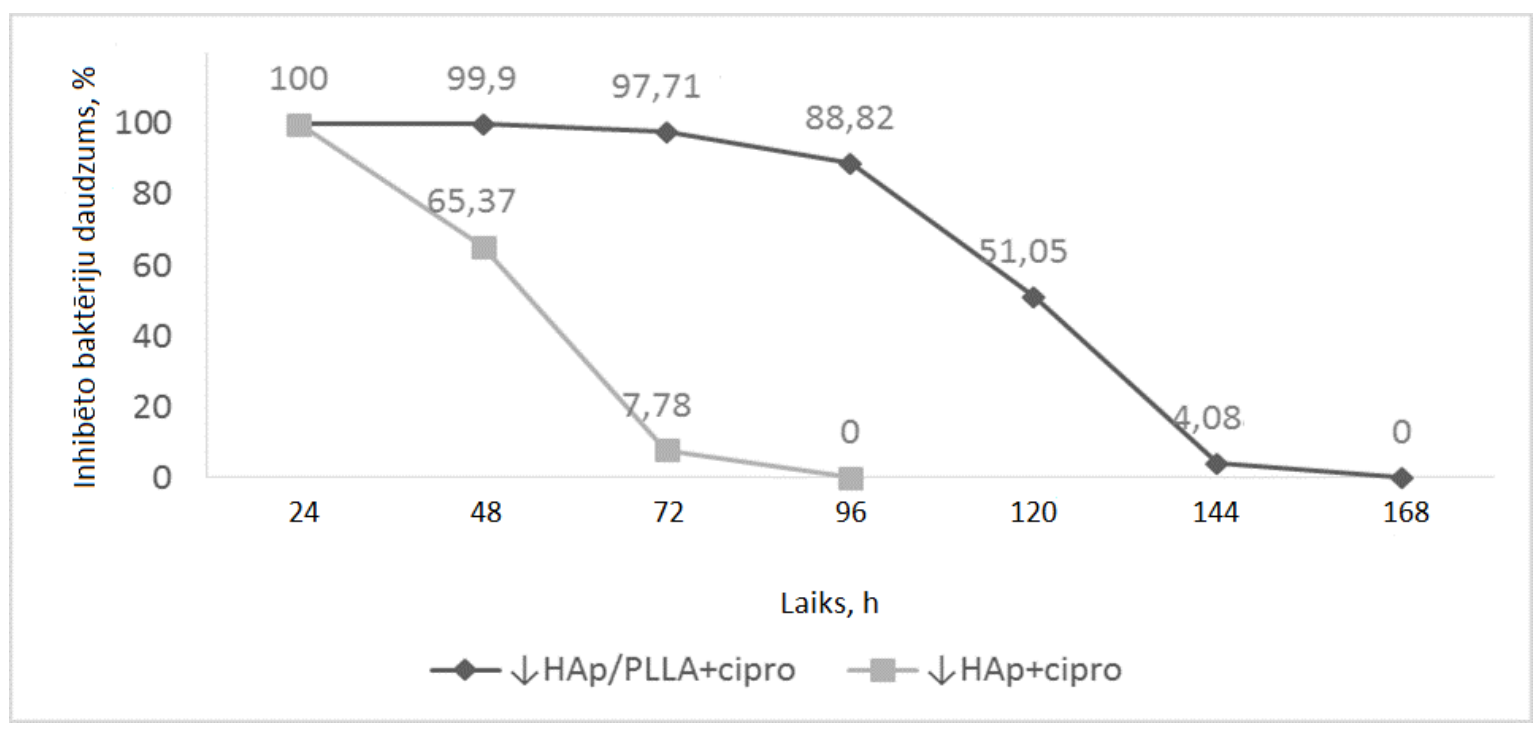

3.13. attēls. $\boldsymbol{P}$. aeruginosa augšanas inhibīcijas dinamika

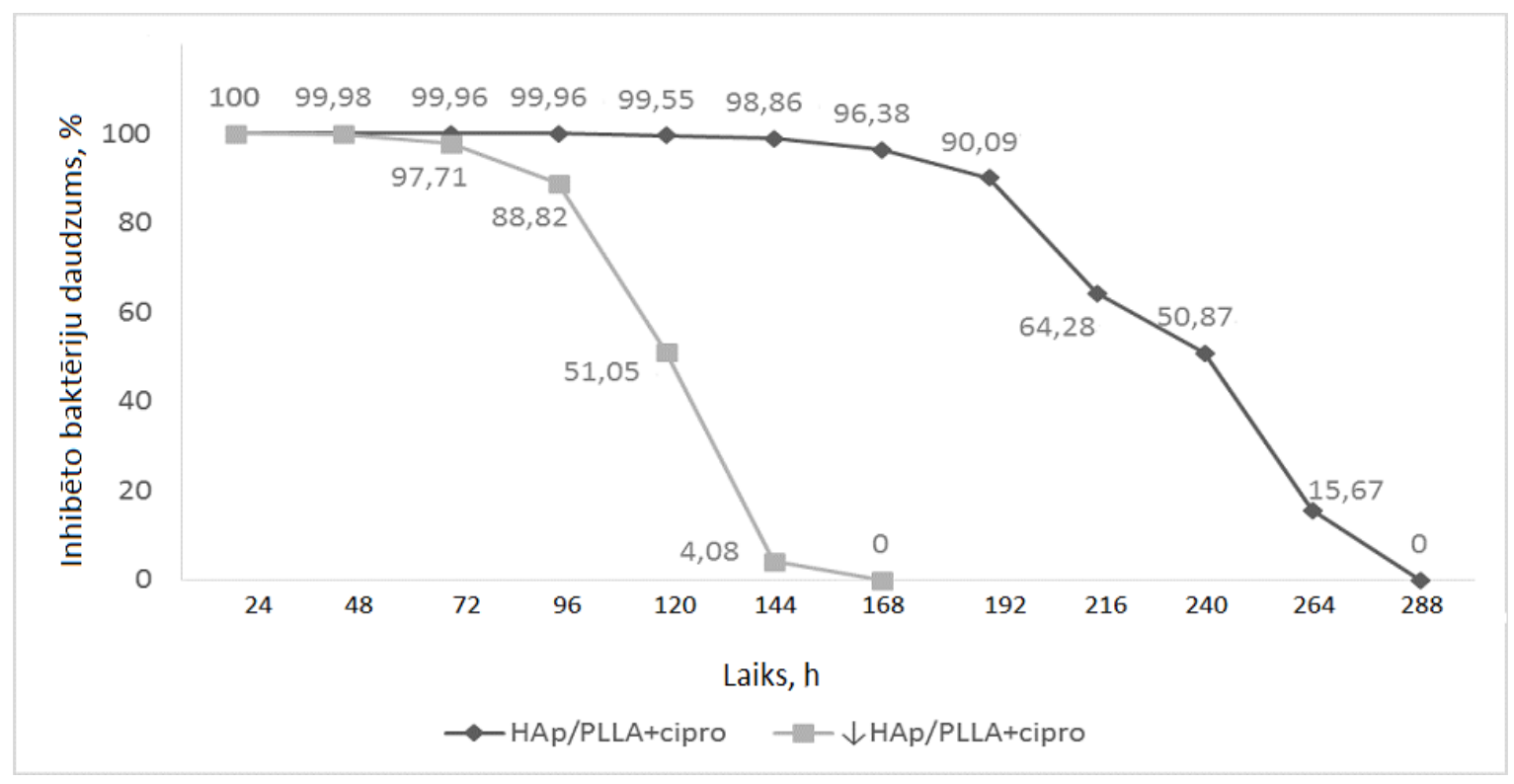

3.14. attēls. $\boldsymbol{P}$. aeruginosa augšanas inhibīcijas dinamika dažādas porainības biomateriāliem 


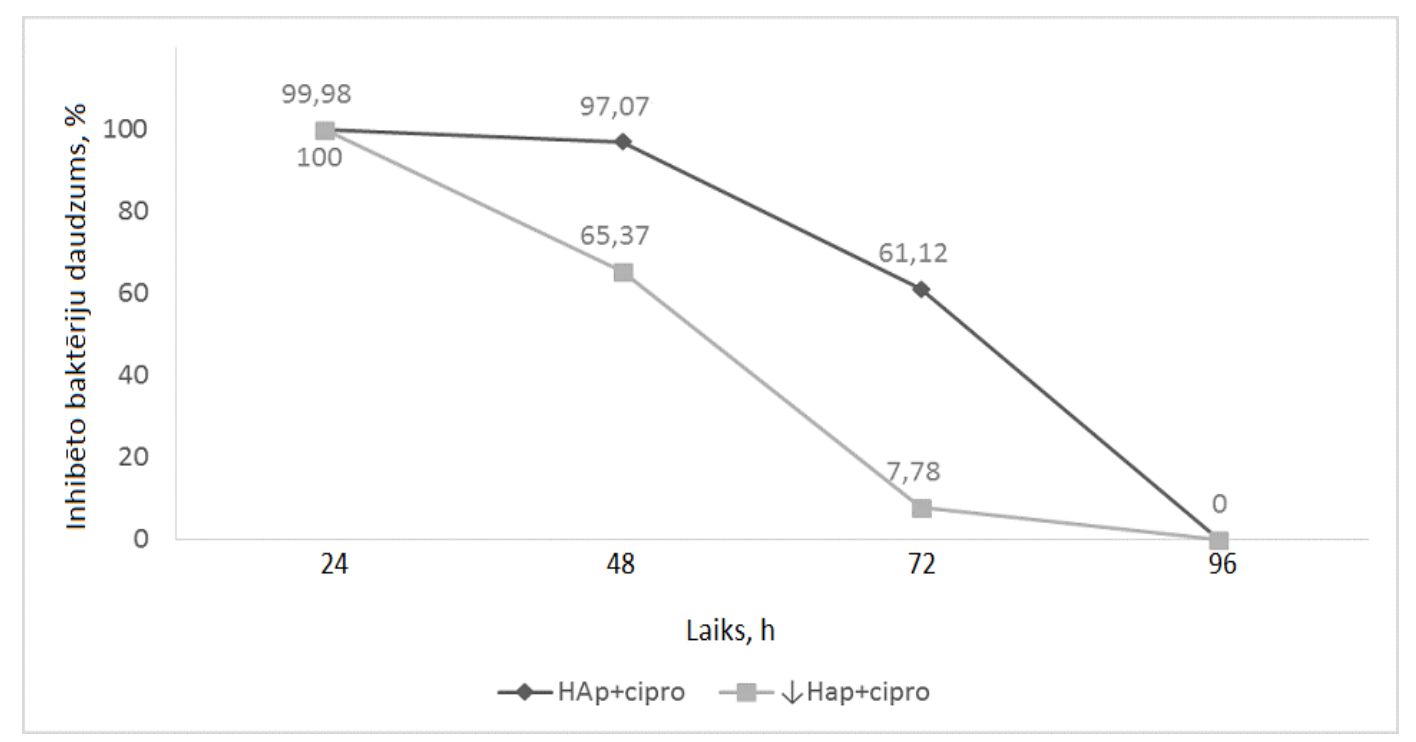

3.15. attēls. $\boldsymbol{P}$. aeruginosa augšanas inhibīcijas dinamika dažādas porainības biomateriāliem bez polimēra

Zemas porainības biomateriālu grupā statistiski ticamas inhibēto baktēriju procentuālās izmaiņas laikā no 24 h līdz 48 h tika novērotas $\downarrow$ HAp+cipro pret $S$. epidermidis kultūru (3.16. attēls) (Manna-Vitnija tests, $\mathrm{p}<0,05$ ), tāpat arī statistiski ticami samazinājās pret P. aeruginosa kultūru (3.17. attēls) (p <0,05).

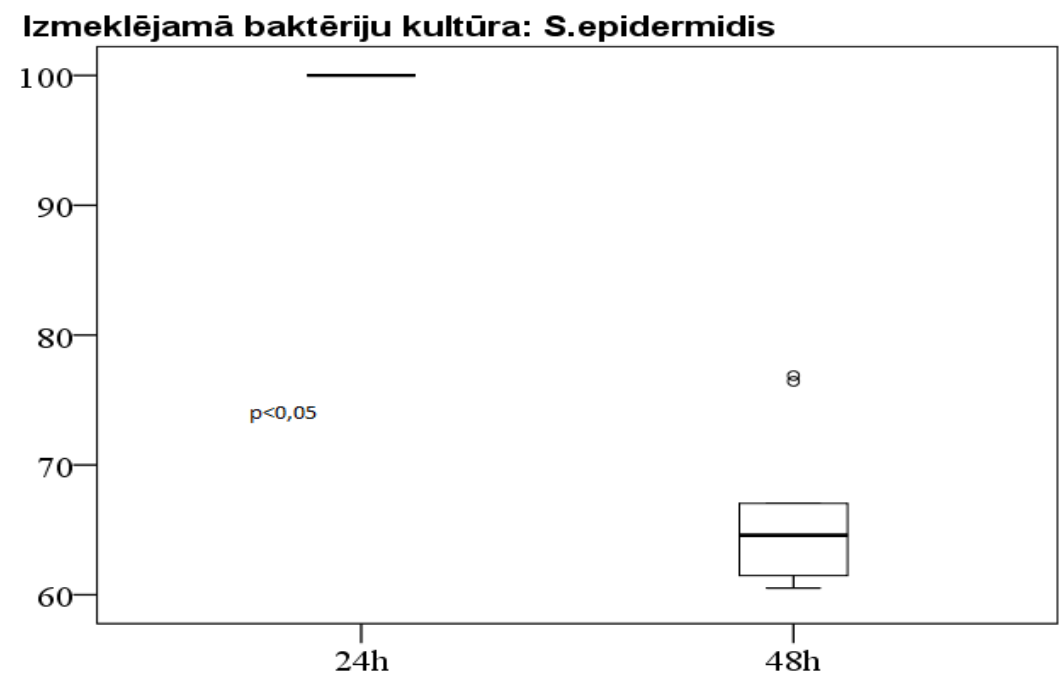

3.16. attēls. $\downarrow$ HAp+cipro inhibēto baktēriju procentuālās izmaiņas laikā no 24 h līdz 48 h 


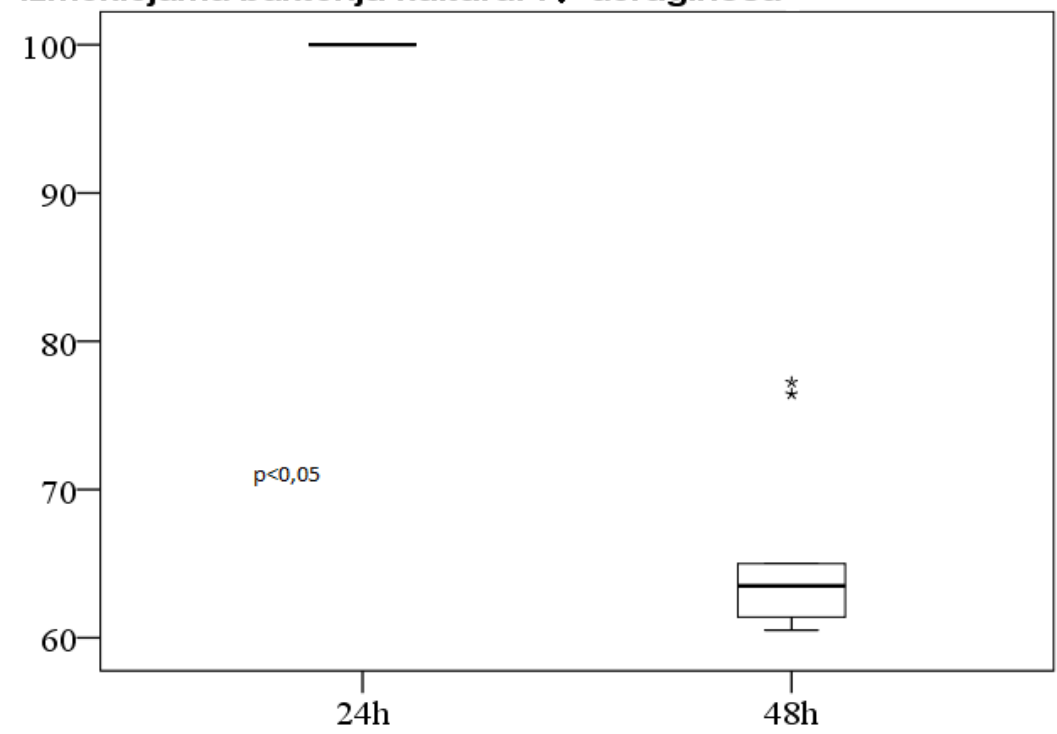

3.17. attēls. $\downarrow$ HAp+cipro inhibēto baktēriju procentuālās izmaiṇas laikā no 24 h līdz 48 h

Pirmajās $24 \mathrm{~h}$ neatkarīgi no PLLA esamības zema porainības līmeņa biomateriāliem statistiski ticamas izmaiņas netika novērotas $(\mathrm{p}<0,05)$, bet izmaiņas sāka notikt in vitro pētījuma $48 \mathrm{~h}$ atskaites posmā, un Manna-Vitnija tests parādīja, ka zema porainības līmeņa biomateriāliem bez PLLA inhibēto baktēriju procentuālās izmainas samazinājums pēc $48 \mathrm{~h}$ ir statistiski ticami lielāks nekā zema porainības līmeņa biomateriāliem ar PLLA $(\mathrm{p}<0,05)$ neatkarīgi no baktēriju kultūras (3.18. attēls).

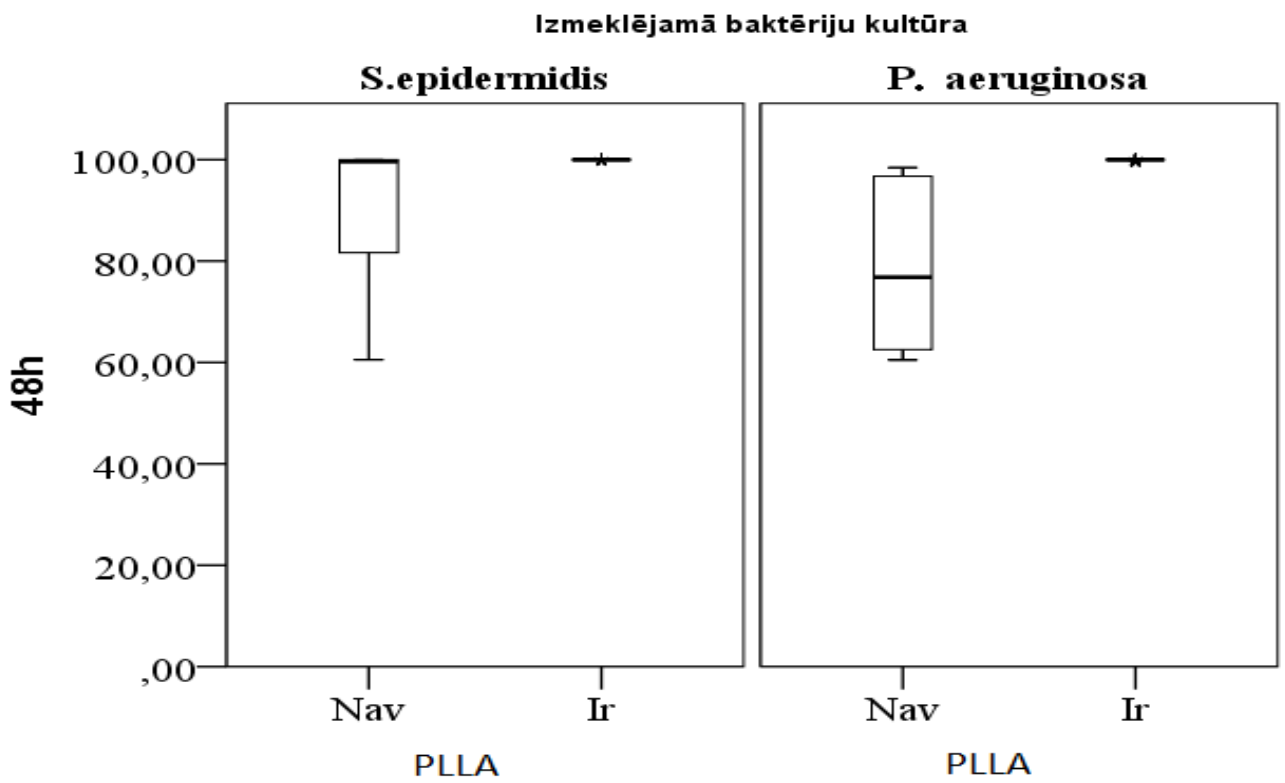

3.18. attēls. PLLA ietekme uz inhibēto baktēriju procentuālajām izmaiṇām pēc $48 \mathrm{~h}$ 


\subsection{CDHAp/PLLA+genta un CDHAp/PLLA+cipro antibakteriālā efektivitāte in vitro}

Izmantojot antibakteriālo īpašību noteikšanas metodi baktēriju suspensijāa, tika noskaidrots, ka CDHAp/PLLA+genta maksimālais antibakteriālais laiks pret S. epidermidis ir 264 h, minimālais antibakteriālais laiks sasniedz 240 h, bet vidējais antibakteriālais laiks pret S. epidermidis ir 249,6 $\pm 16,78 \mathrm{~h}$ (3.19. attēls).

CDHAp/PLLA biomateriālam pret $S$. epidermidis un $P$. aeruginosa antibakteriālās īpašības netika novērotas.

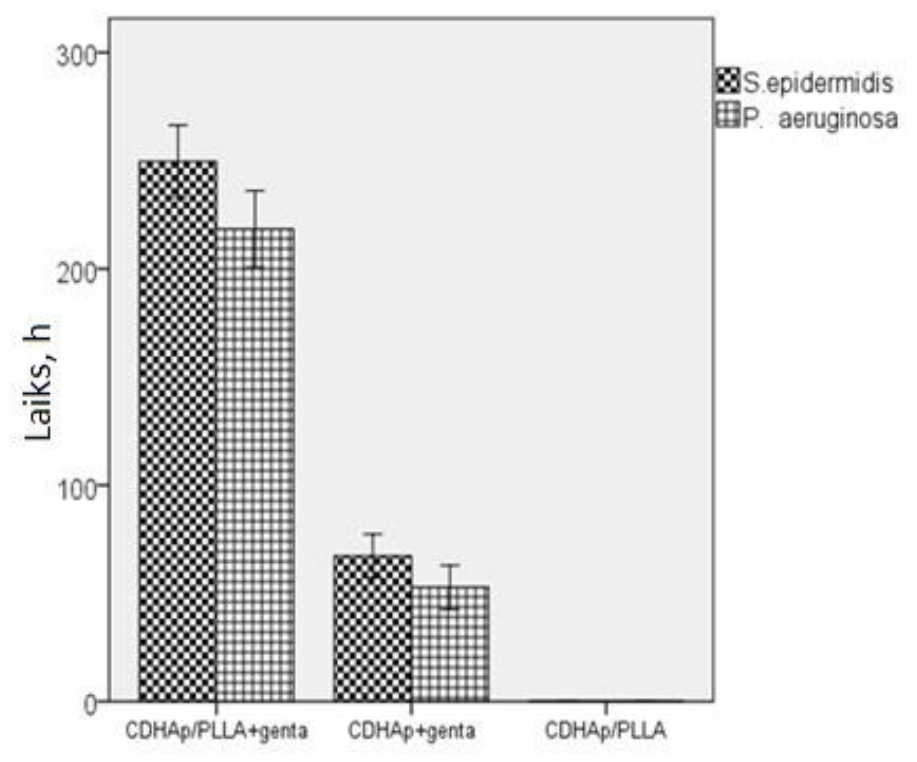

3.19. attēls. Vidējais antibakteriālais laiks kompozītmateriāliem ar gentamicīnu

Ar Manna-Vitnija testu tika apstiprināts, ka CDHAp/PLLA+genta un CDHAp+genta antibakteriālie laiki pret $S$. epidermidis statistiski ticami $(\mathrm{p}<0,001)$ atšķ̧iras. CDHAp/PLLA+genta pilnībā inhibēja $S$. epidermidis augšanu pētījuma pirmajās 5 dienās (3.20. attēls) un pēc tam šīs spējas zaudēja pakāpeniski, savukārt CDHAp+genta pilnībā inhibēja S. epidermidis augšanu tikai pirmajā pētîjuma dienā, bet jau otrajā dienā novēroja strauju-antibakteriālo īpašību zudumu. 


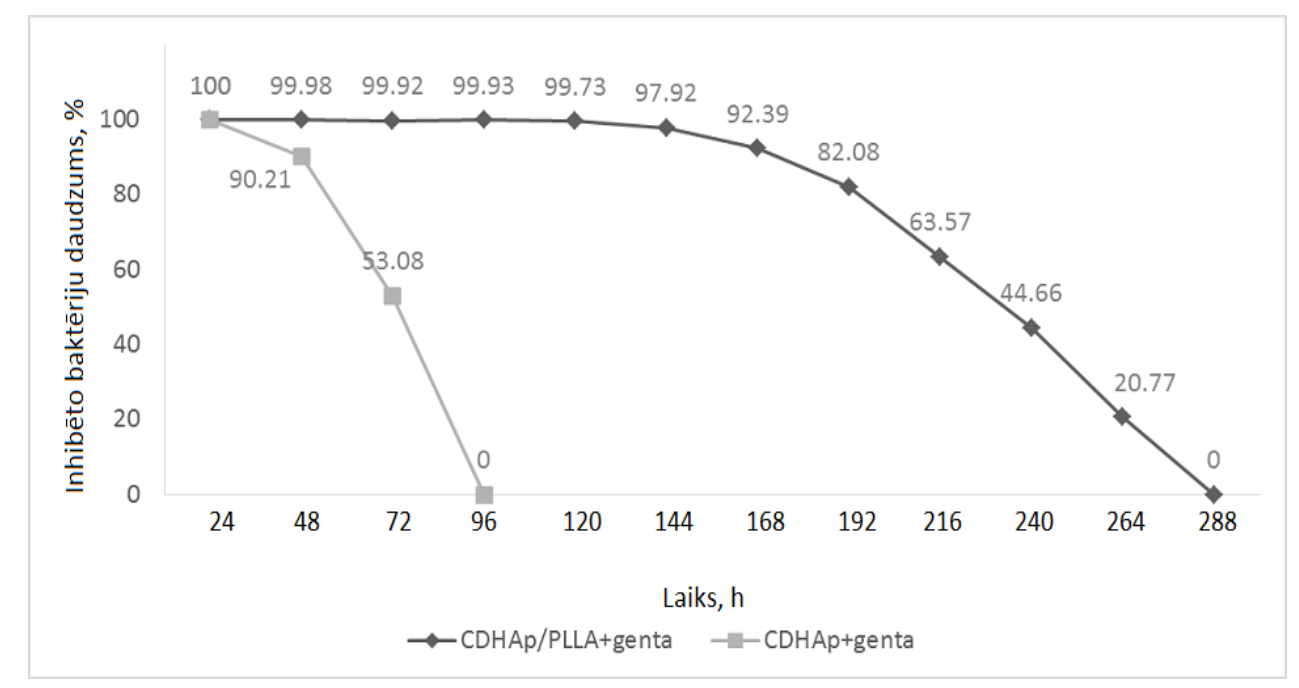

3.20. attēls. S. epidermidis augšanas inhibīcijas dinamika kompozītmateriāliem ar gentamicīnu

Statistiski ticamas izmaiņas no $24 \mathrm{~h}$ līdz $48 \mathrm{~h}$ tika novērotas CDHAp+genta pret S. epidermidis kultūrai (Manna-Vitnija tests, p < 0,05), (3.21. attēls).

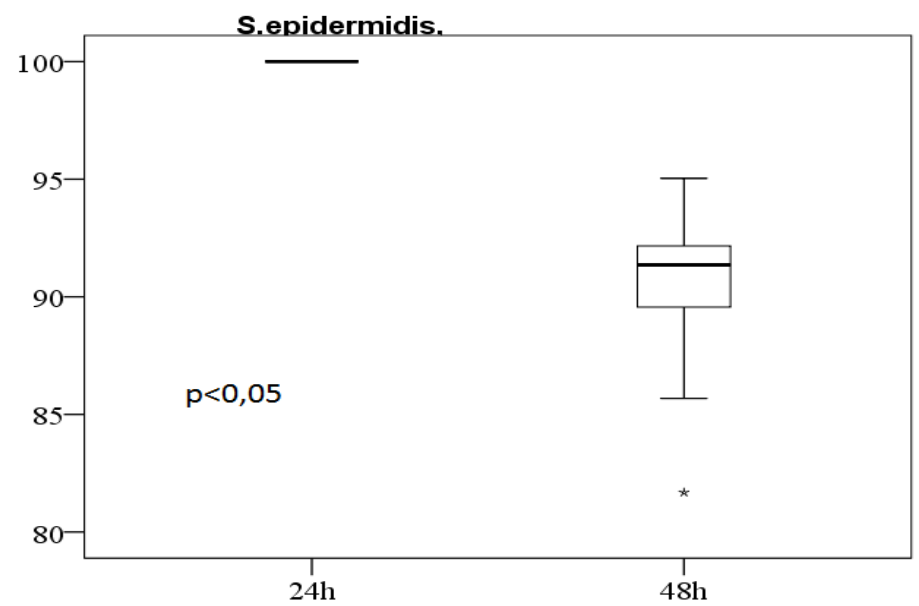

3.21. attēls. CDHAp+genta inhibēto baktēriju procentuālās izmaiṇas laikā no 24 h līdz 48 h

CDHAp+genta maksimālais antibakteriālais laiks pret $S$. epidermidis bija ir $72 \mathrm{~h}$, un minimālais antibakteriālais laiks bija ir 48 h, veidojot vidējo antibakteriālo laiku 67,2 $\pm 10,11$ h. CDHAp/PLLA+genta un CHAp+genta spēja inhibēt $P$. aeruginosa augšanu ir līdzīga kā pret S. epidermidis, tikai CDHAp/PLLA+genta kopējā $P$. aeruginosa augšanas inhibīcijas dinamikā (3.22. attēls) uzrāda ātrāku antibakteriālo îpašību zaudēšanu kopumā, kā arī maksimālais un minimālais antibakteriālais laiks ir atšķirīgs, un sasniedz attiecīgi, $240 \mathrm{~h}$ un $196 \mathrm{~h}$. 


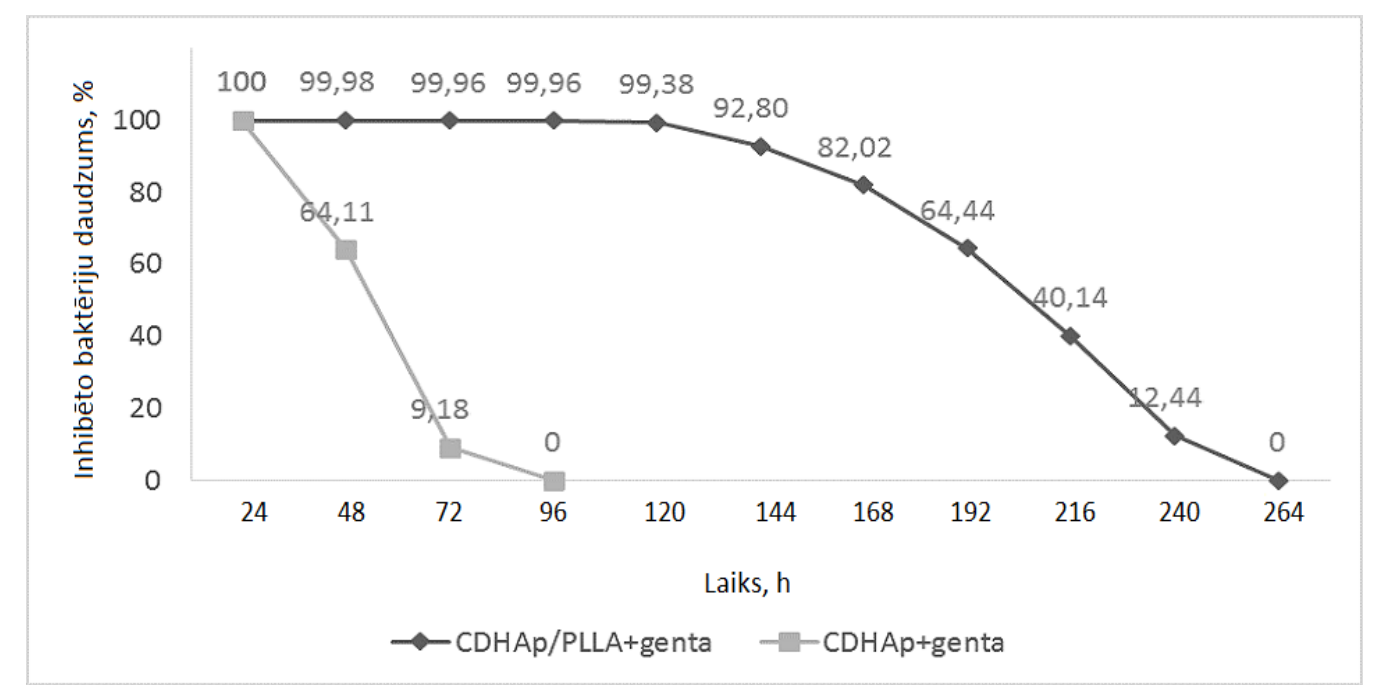

3.22. attēls. $P$. aeruginosa augšanas inhibīcijas dinamika kompoz̄itmateriāliem ar gentamicīnu

Statistiski ticamas izmaiņas no $24 \mathrm{~h}$ uz $48 \mathrm{~h}$ tika novērotas CDHAp+genta pret $P$. aeruginosa baktēiju kultūru (3.23. attēls) (Manna-Vitnija tests, $\mathrm{p}<0,05$ ), tāpat kā statistiski ticami samazinājās pret $S$. epidermidis kultūru $(\mathrm{p}<0,05)$. Pārējiem CDHAp/PLLA+genta biomateriāliem statistiski ticamas izmainas netika novērotas (MannaVitnija tests, $p>0,05$ )

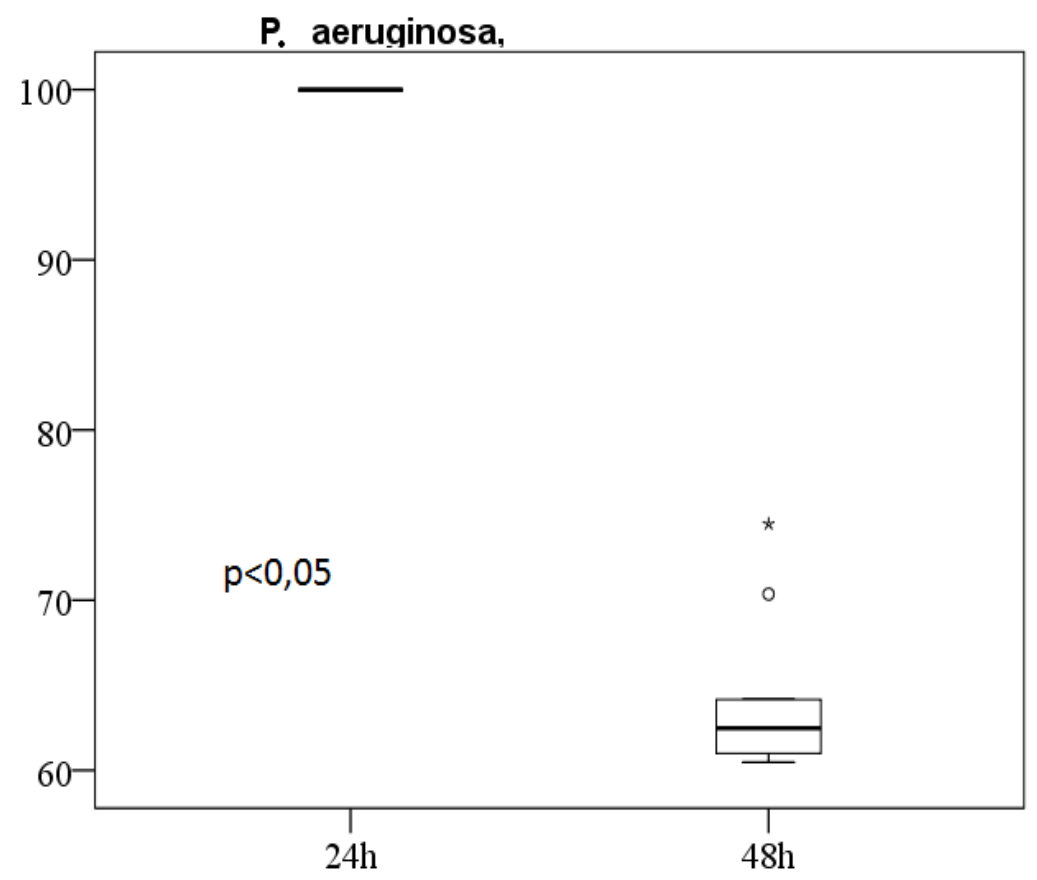

3.23.attēls. CDHAp+genta inhibēto baktēriju procentuālās izmaiṇas laika dinamikā no 24 h uz 48 h 
Šādas statistiski ticamas izmaiņas no 24 h uz 48 h arī nenovēroja CDHAp/PLLA+cipro un CDHAp+cipro ( $\mathrm{p}>0,05)$ pret $S$. epidermidis un $P$. aeruginosa. CDHAp+cipro statistiski ticamas izmainas $(\mathrm{p}<0,05)$ novēroja pret abām in vitro pētījumā izmantotajām baktēriju grupām laika atskaites posmos no $48 \mathrm{~h}$ uz $72 \mathrm{~h}$, bet CDHAp/PLLA+cipro šadas statistiski ticamas izmaiṇas minētajā laika posmā nenovēroja ne pret vienu no baktēriju kultūrām. CDHAp/PLLA+cipro novēroja S. epidermidis augšanas inhibīcijas spēju pakāpenisku zudumu (3.24. attēls), un salīdzinot ar tās pašas grupas biomateriāliem bez PLLA (CDHAp+cipro), antibakteriālais laiks ir statistiski ticami $(\mathrm{p}<0,001)$ ilgāks pret S. epidermidis.

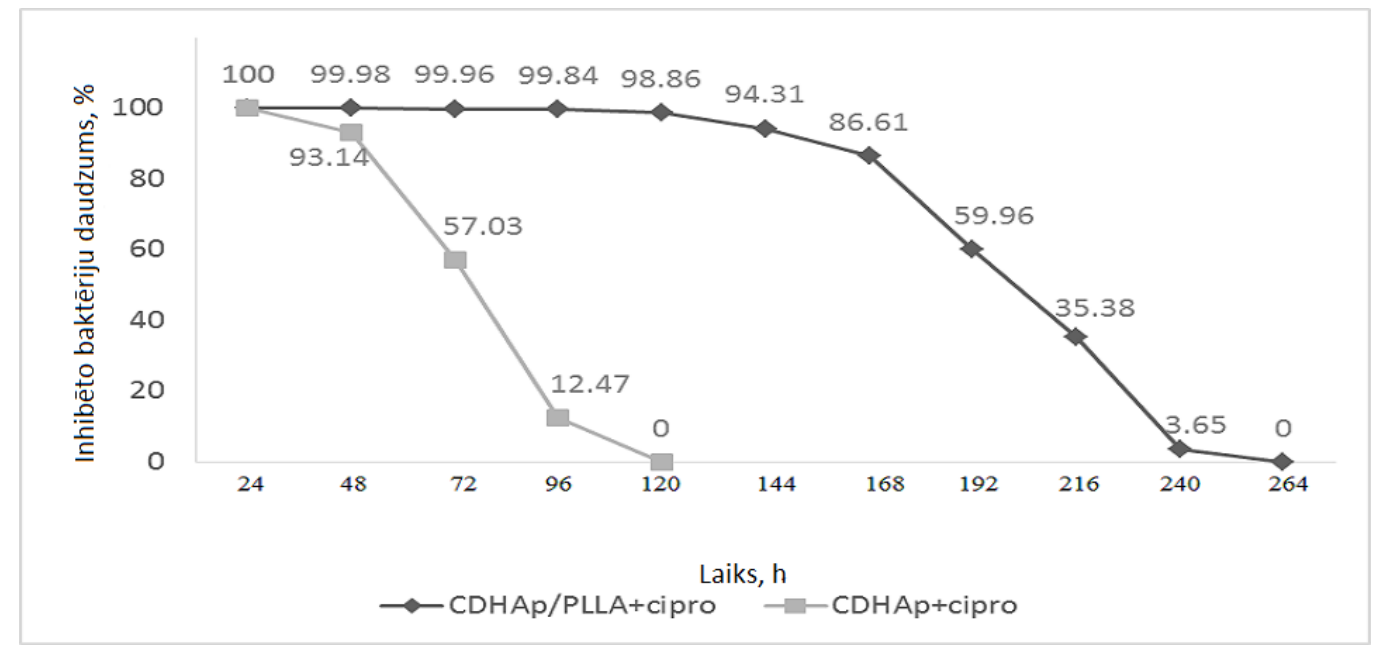

3.24. attēls. $S$. epidermidis augšanas inhibīcijas dinamika

Ja salīdzina CDHAp/PLLA+cipro ar CDHAp/PLLA+genta antibakteriālo darbību pret S. epidermidis, tad var novērot, ka CDHAp/PLLA+cipro antibakteriālais laiks ir īsāks un sasniedz 213,6 \pm 13,62 h (3.25. attēls). Maksimālais antibakteriālais laiks, ko spēja uzrādīt CDHAp/PLLA+cipro pret S. epidermidis, bija 240 h, minimālais - 192 h. CDHAp+cipro uzrādīja ilgāku antibakteriālo laiku pret S. epidermidis nekā CDHAp+genta, bet statistiski ticamas izmaiņas nenovēroja $(\mathrm{p}>0,05)$.

CDHAp/PLLA+cipro un CDHAp+cipro saglabājas kompozītmateriāliem raksturīgas inhibīcijas spējas pret $P$. aeruginosa (3.26. attēls), jo CDHAp/PLLA+cipro gadījumā novēroja ilgstošas spējas nomākt $P$. aeruginosa baktēriju augšanu, un šīs spējas zuda pakāpeniski. CDHAp+cipro izteiktas antibakteriālās spējas novēroja pirmajās pētījuma dienās. Tika novērotas raksturīgās straujās antibakteriālo īpašību kritumu ar strauju antibiotisko vielu izdali pirmajās pētījuma dienās. 


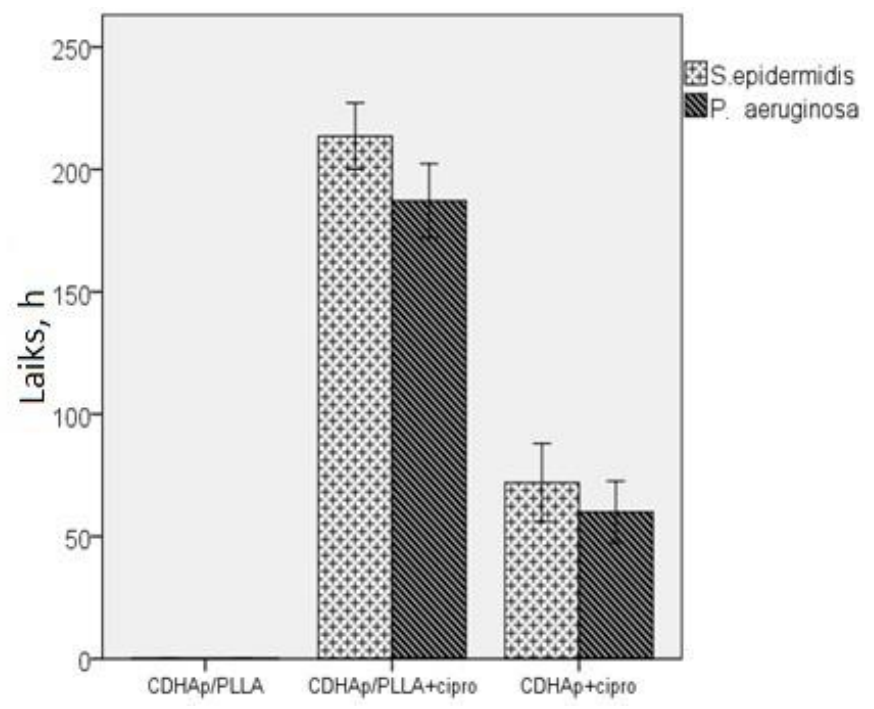

3.25. attēls. Vidējais antibakteriālais laiks kompozītmateriāliem ar kalcija deficītu, ciprofloksacinnu un PLLA

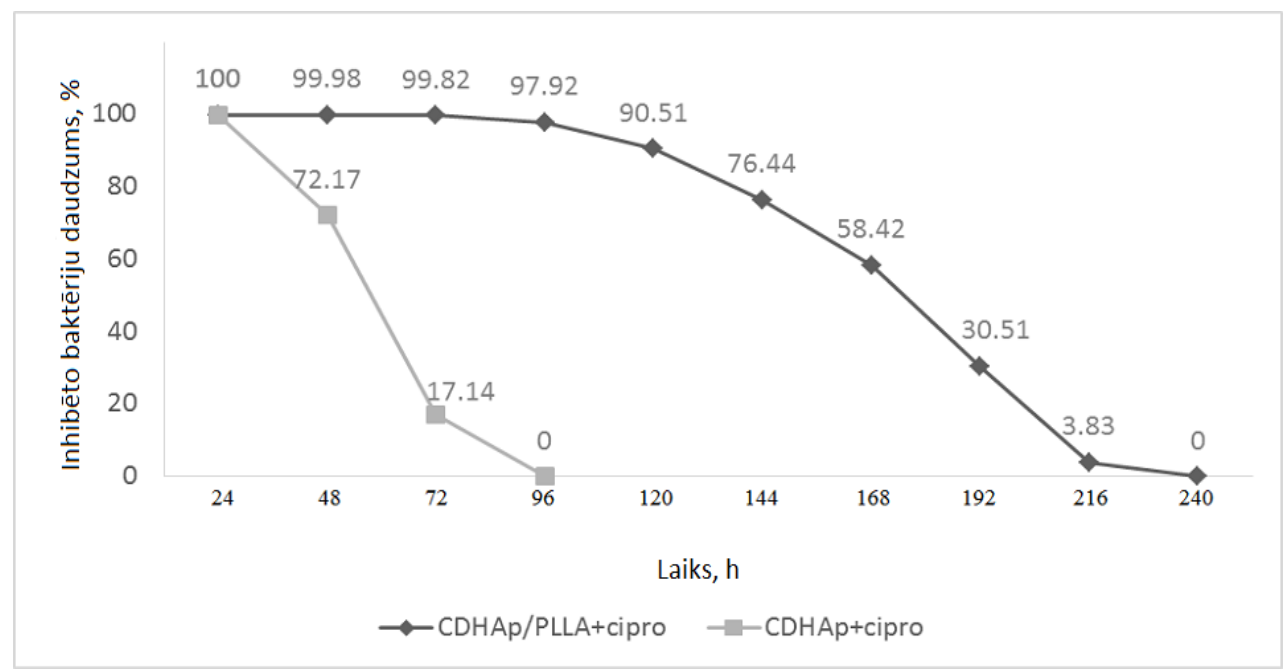

3.26. attēls. $P$. aeruginosa augšanas inhibīcijas dinamika

CDHAp+cipro biomateriālā statistiski ticamas inhibēto baktēriju procentuālās izmaiņas (Manna-Vitnija tests, $\mathrm{p}<0,05$ ) novēroja pētījuma atskaites laika posmos no $48 \mathrm{~h}$ uz $72 \mathrm{~h}$ pret P. aeruginosa. CDHAp+cipro maksimālais antibakteriālais laiks $72 \mathrm{~h}$, un minimālais antibakteriālais laiks pret $P$. aeruginosa ir 48 h. Savukārt CDHAp/PLLA+cipro maksimālais antibakteriālais laiks pret $P$. aeruginosa ir ievērojami ilgāks nekā CDHAp+cipro, un sasniedz 192 h, bet tas ir mazāks nekā pret S. epidermidis. Ar Manna-Vitnija testu novēro statistiski ticamas atšķirības $(\mathrm{p}<0,001)$ starp CDHAp/PLLA+cipro un CDHAp+cipro antibakteriālajiem laikiem pret $P$. aeruginosa. Salīdzinot dažādu kompozītmateriālu antibakteriālās īpašības, tad redzams, ka ir statistiski ticamas (Manna-Vitnija tests, $\mathrm{p}<0,001$ ) atšķirības starp Hap/PLLA+cipro un CDHAp/PLLA+cipro pret abām baktēriju kultūrām 
(3.27. attēls un 3.28. attēls), savukārt tiem pašiem kompozītmateriāliem ar gentamicīnu nenovēru statistiski ticamas (Manna-Vitnija tests, $\mathrm{p}>0,05$ ) atšķirīibas pret abām baktēriju kultūrām (3.29. attēls un 3.30. attēls).

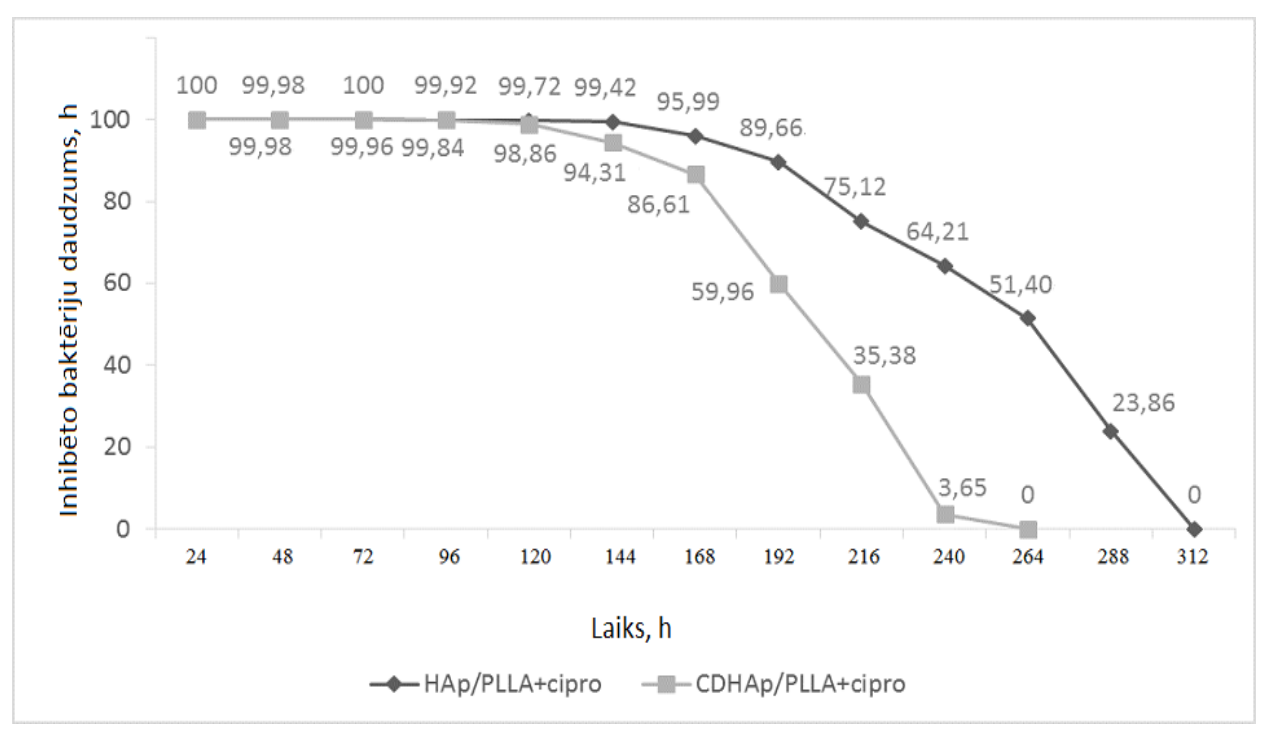

3.27. attēls. S. epidermidis augšanas inhibīcijas dinamika dažādiem kompoz̄itmateriāliem

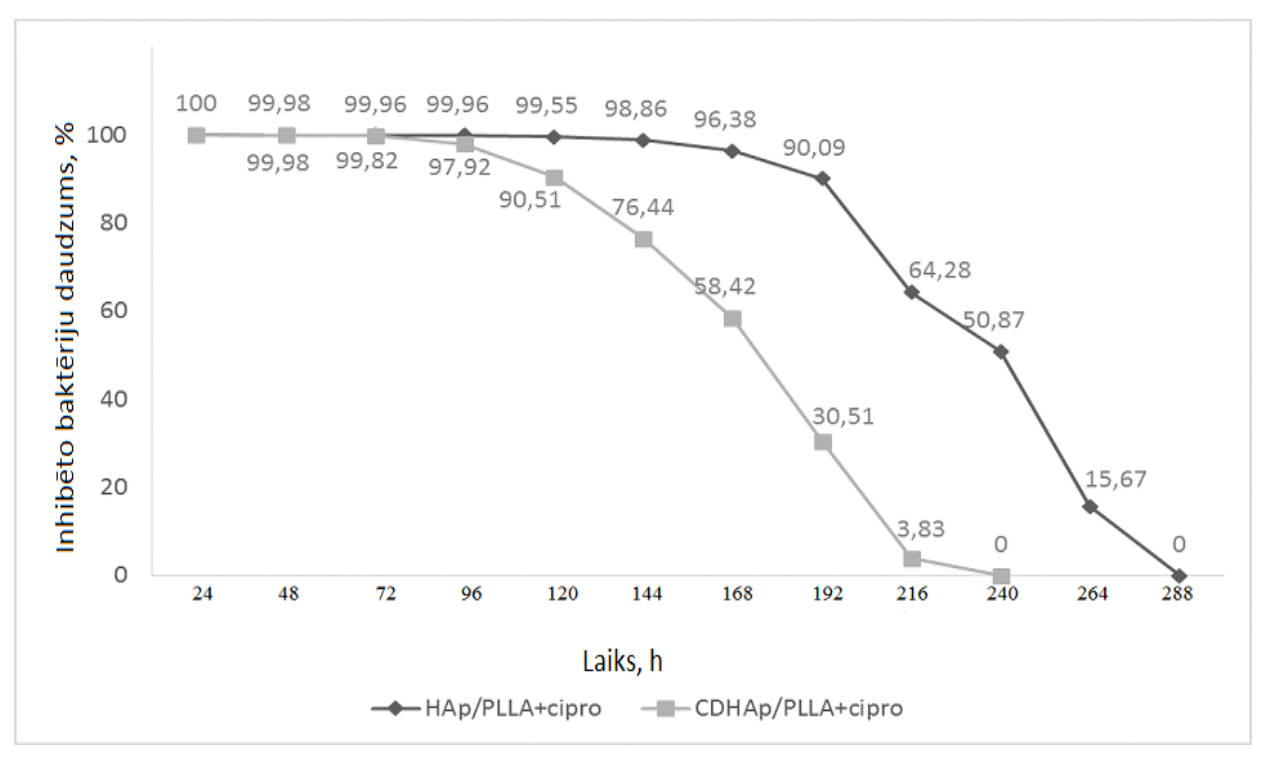

3.28.attēls. $P$. aeruginosa augšanas inhibīcijas dinamika dažādiem kompozītmateriāliem 


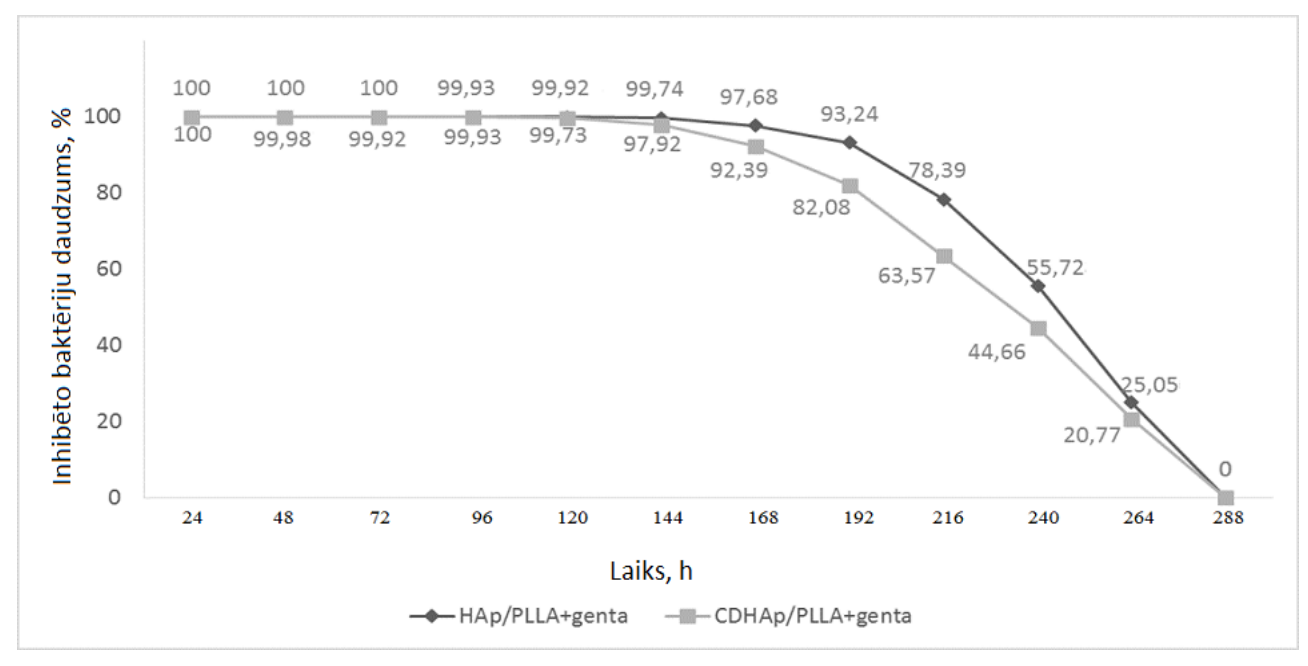

3.29. attēls. S. epidermidis augšanas inhibīcijas dinamika dažādiem kompozītmateriāliem ar gentamicīnu

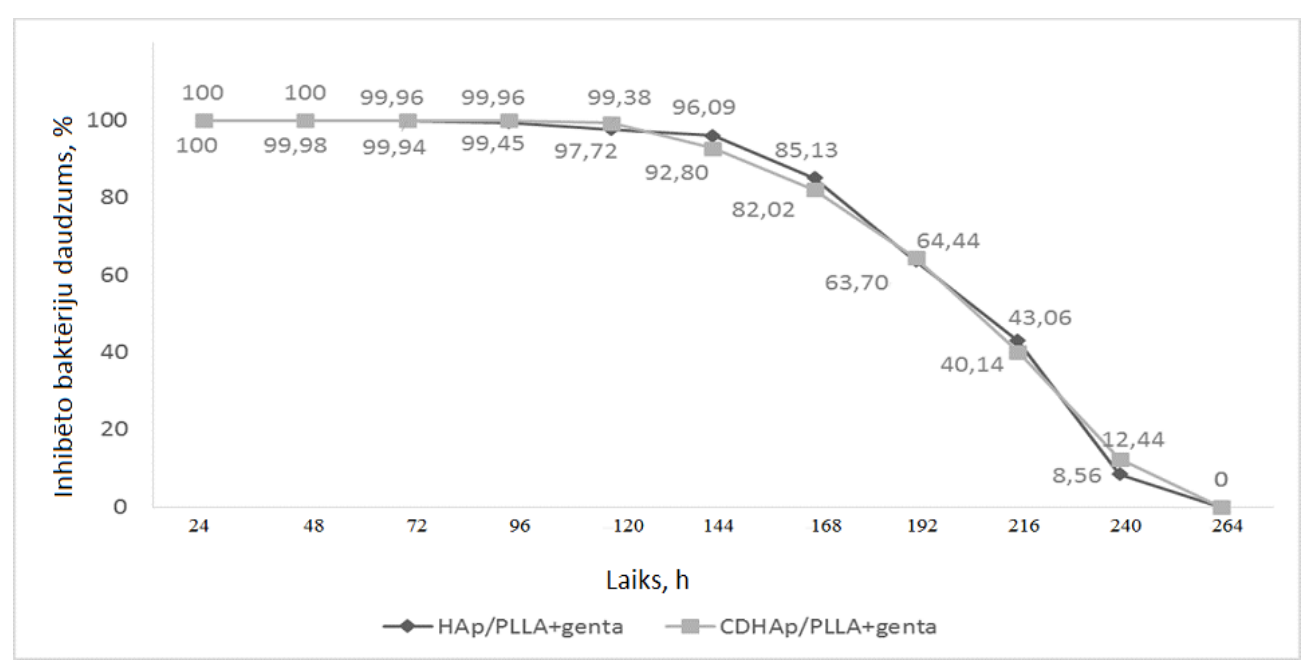

3.30. attēls. $P$. aeruginosa augšanas inhibīcijas dinamika dažādiem kompozītmateriāliem ar gentamicīnu

Starp dažādiem kompozītmateriāliem ar antibiotiskajām vielām bez polimēra novēro statistiski ticamas (Manna-Vitnija tests, $\mathrm{p}<0,001$ ) atšķirības antibakteriālajā laikā un baktēriju inhibīcijas dinamikā pret abām baktēriju kultūrām (3.31. attēls, 3.32. attēls, 3.33. attēls, 3.34. attēls). 


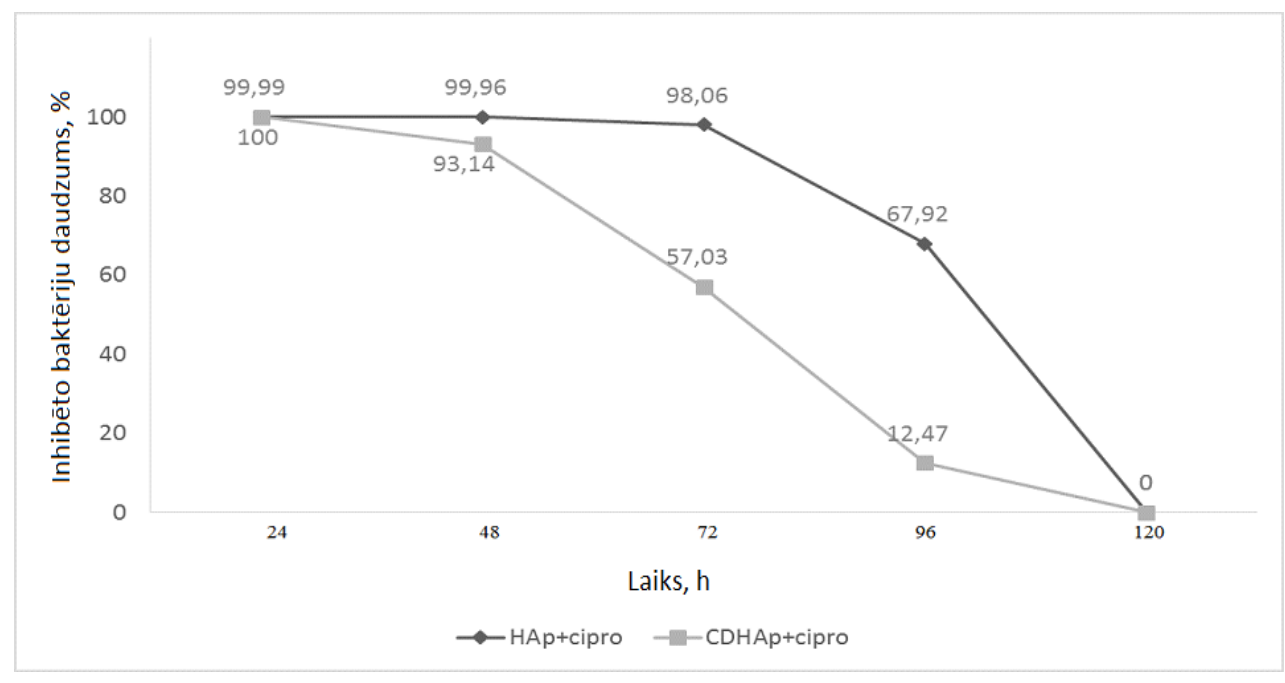

3.31. attēls. $S$. epidermidis augšanas inhibīcijas dinamika dažādiem kompozītmateriāliem ar ciprofloksacīnu bez polimēra

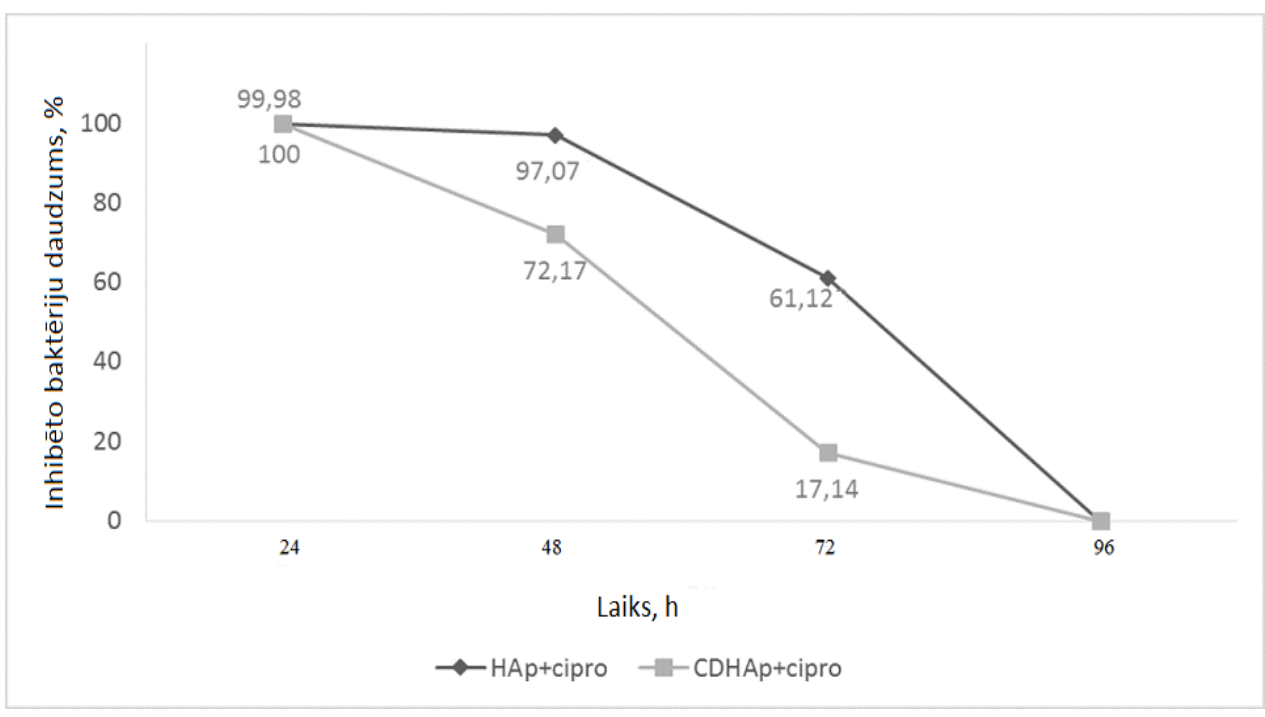

3.32. attēls. $\boldsymbol{P}$. aeruginosa augšanas inhibīcijas dinamika dažādiem kompozītmateriāliem ar ciprofloksacīnu bez polimēra

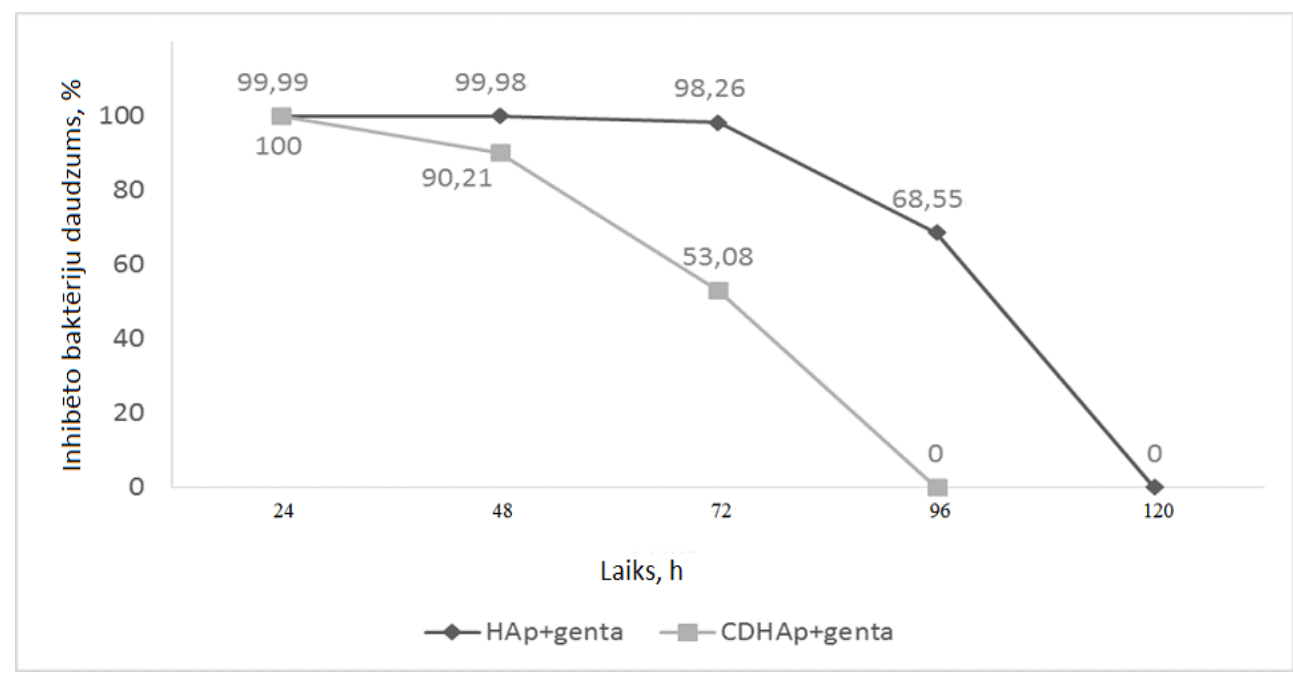

3.33. attēls. S. epidermidis augšanas inhibīcijas dinamika dažādiem kompoz̄̄tmateriāliem ar gentamicīnu bez polimēra 


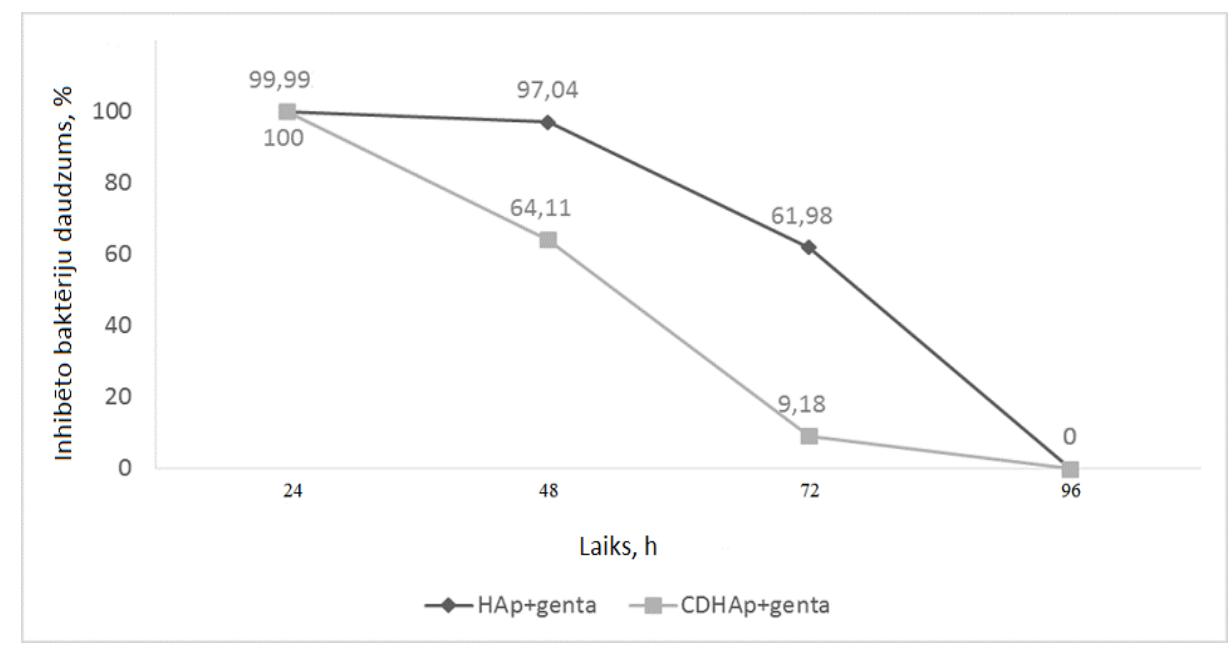

3.34. attēls. $P$. aeruginosa augšanas inhibīcijas dinamika dažādiem kompoz̄̄tmateriāliem ar gentamicīnu bez polimēra

\subsection{CDHAp/PCL+genta un CDHAp/PCL+cipro antibakteriālā efektivitāte in vitro}

Pētījuma ietvaros tika izpētīti arī kompozītmateriāli ar citu bionoārdošos polimēru PCL, kuri savienoti-ar antibiotiskajām vielām. Izmantojot Manna-Vitnija testu ir redzams, ka CDHAp/PCL+genta biomateriāliem ir statistiski ticami $(\mathrm{p}<0,001)$ atšķirīgss antibakteriālais laiks nekā CDHAp/PLLA+genta pret S. epidermidis. Statistiski ticami atšķiras $(\mathrm{p}<0,001)$ arī CDHAp/PCL+genta antibakteriālais laiks salīdzinot ar CDHAp+genta pret S. epidermidis. CDHAp/PCL+genta pētījumā parāda visilgāko antibakteriālo laiku (3.35. attēls) pret S. epidermidis, sasniedzot antibakteriālo ilgumu 319,2 $\pm 16,19 \mathrm{~h}$.

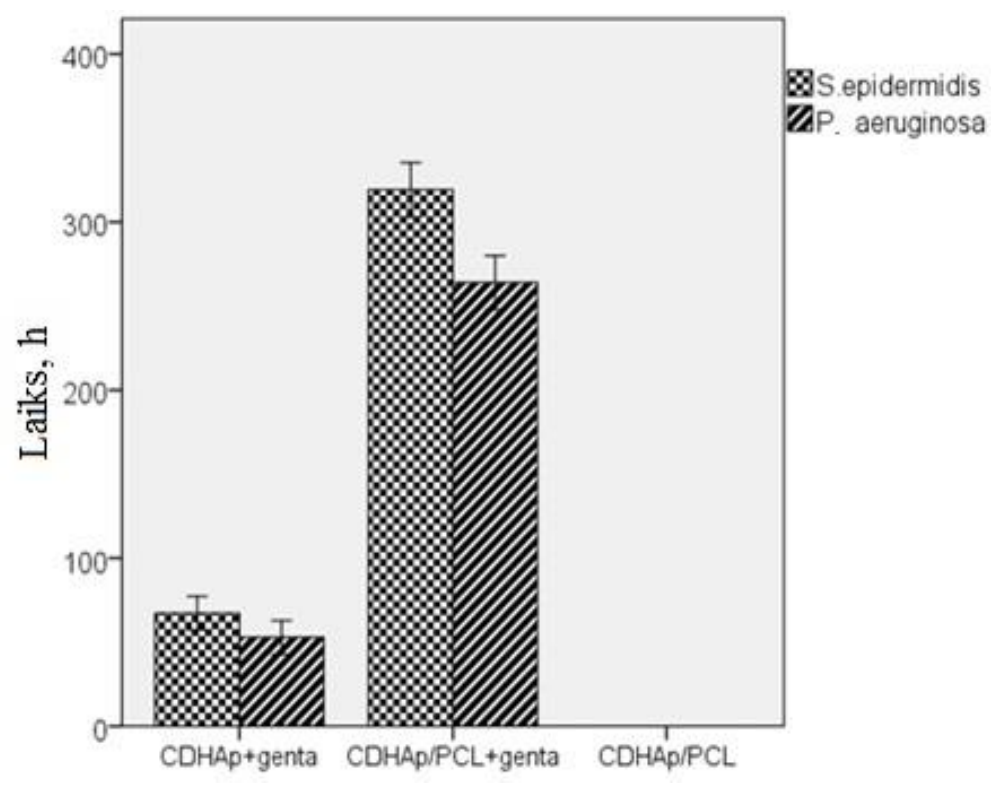

3.35. attēls. Vidējais antibakteriālais laiks kompozītmateriāliem ar kalcija deficìtu, gentamicīnu un PCL 
Ilgais CDHAp/PCL+genta antibakteriālais laiks ir saistīts ar atsevišķu paraugu ilgo maksimālo antibakteriālo laiku pret S. epidermidis - 336 h, un minimālo antibakteriālo laiku 288 h. Pret $P$. aeruginosa CDHAp/PCL+genta maksimālais antibakteriālais laiks sasniedz 288h, un minimālais antibakteriālais laiks ir $240 \mathrm{~h}$.

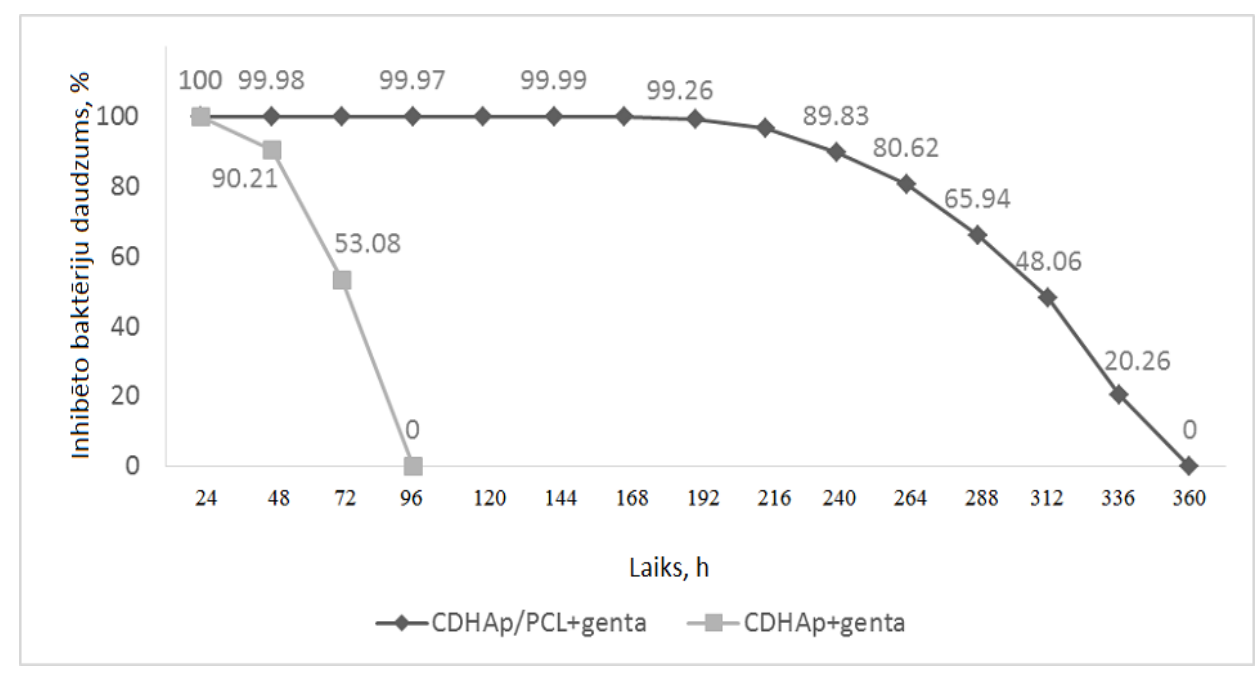

3.36. attēls. S. epidermidis augšanas inhibīcijas dinamika

CDHAp/PCL+genta spēja inhibēt $S$. epidermidis augšanu piln̄̄bā saglabājas ilgu laiku no 192 h līdz 216 h (3.24.attēls), un arī vēlāk, pilnībā S. epidermidis augšana netiek nomākta, antibakteriālās īpašības tiek zaudētas pakāpeniski. Biomateriālu paraugi bez PCL antibakteriālās spējas zaudē strauji, un in vitro pêtījuma laika atzīmē no 24 h līdz 48 h novēro statistiski ticamas atšķirības inhibēto baktēriju procentuālā rādītājā $(\mathrm{p}<0,05)$ izmantojot Manna-Vitnija testu.

Pilna $P$. aeruginosa augšanas inhibīcija (3.37. attēls) CDHAp/PCL+genta tika novērota līdz pētìjuma 168 stundu atzīmei. Un pētījuma turpinājumā novēroja kopējo tendenci viesiem kompozītmateriāliem ar antibiotiskajām vielām un bionoārdāmu polimēru, ka antibakteriālās spējas tiek zaudētas pakāpeniski. 


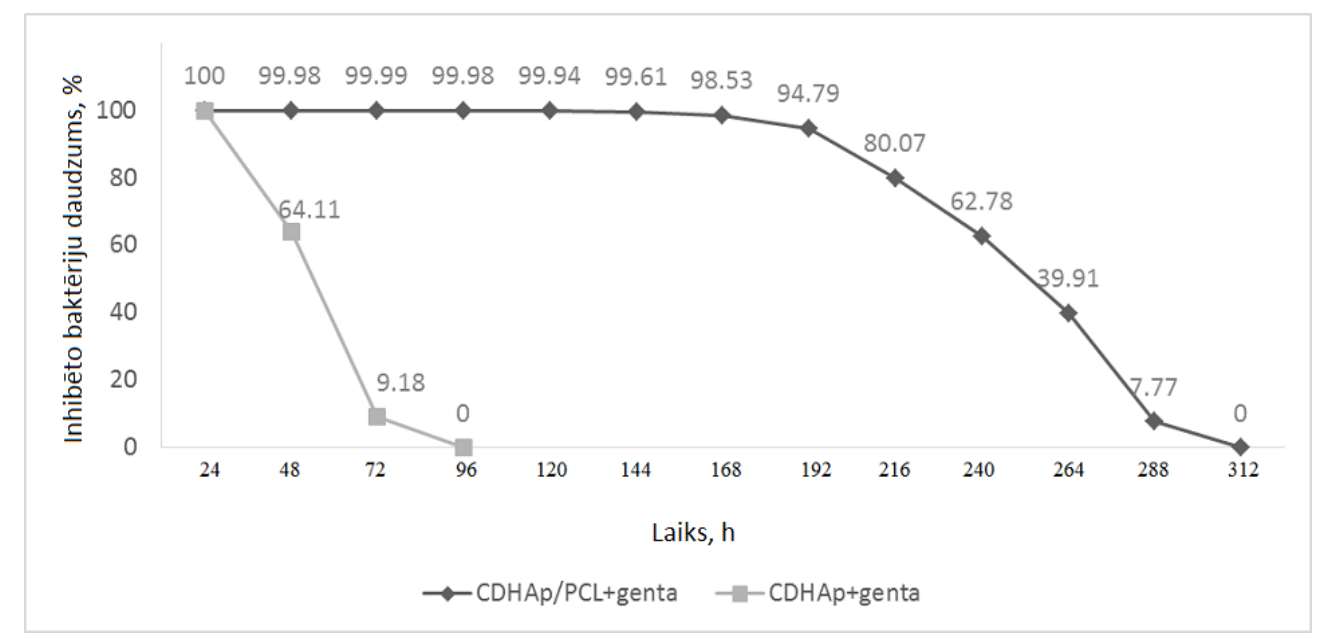

3.37. attēls. $P$. aeruginosa inhibīcijas dinamika

CDHAp/PCL+genta pret P.aeruginosa nenovēroja statiski ticamas $(\mathrm{p}>0,05)$ izmainas pētījuma laika posmā no $24 \mathrm{~h}$ uz $48 \mathrm{~h}$, un arī pētījuma laika posmā no $48 \mathrm{~h}$ uz 72 h, bet CDHAp+genta novēro statistiski ticamas $(\mathrm{p}<0,05)$ izmaiņas gan pētījuma laika posmā no 24 h uz 48 h, gan pētījuma laika posmā no 48 h uz 72h.

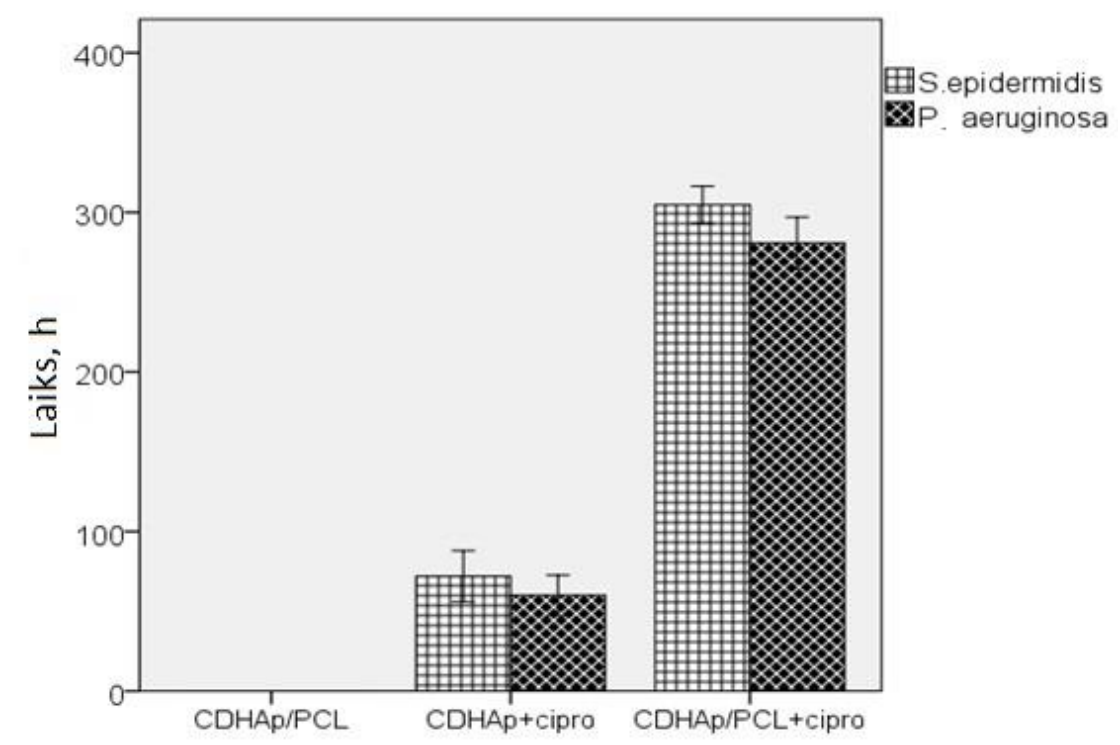

3.38. attēls. Vidējais antibakteriālais laiks kompozītmateriāliem ar kalcija deficītu, ciprofloksacīnu un PCL

Visilgāko antibakteriālo laiku pētījumā pret $P$. aeruginosa uzrāda CDHAp/PCL+cipro, sasniedzot 280,8 $\pm 16,19$ h. Maksimālais antibakteriālais laiks pret $P$. aeruginosa CDHAp/PCL+cipro ir 312 h, bet minimālais - 264 h (3.38. attēls). Manna-Vitnija tests uzrāda, ka starp CDHAp/PCL+cipro un CDHAp+cipro pret $P$. aeruginosa ir statistiski ticama atškirīiba $(\mathrm{p}<0,001)$. 


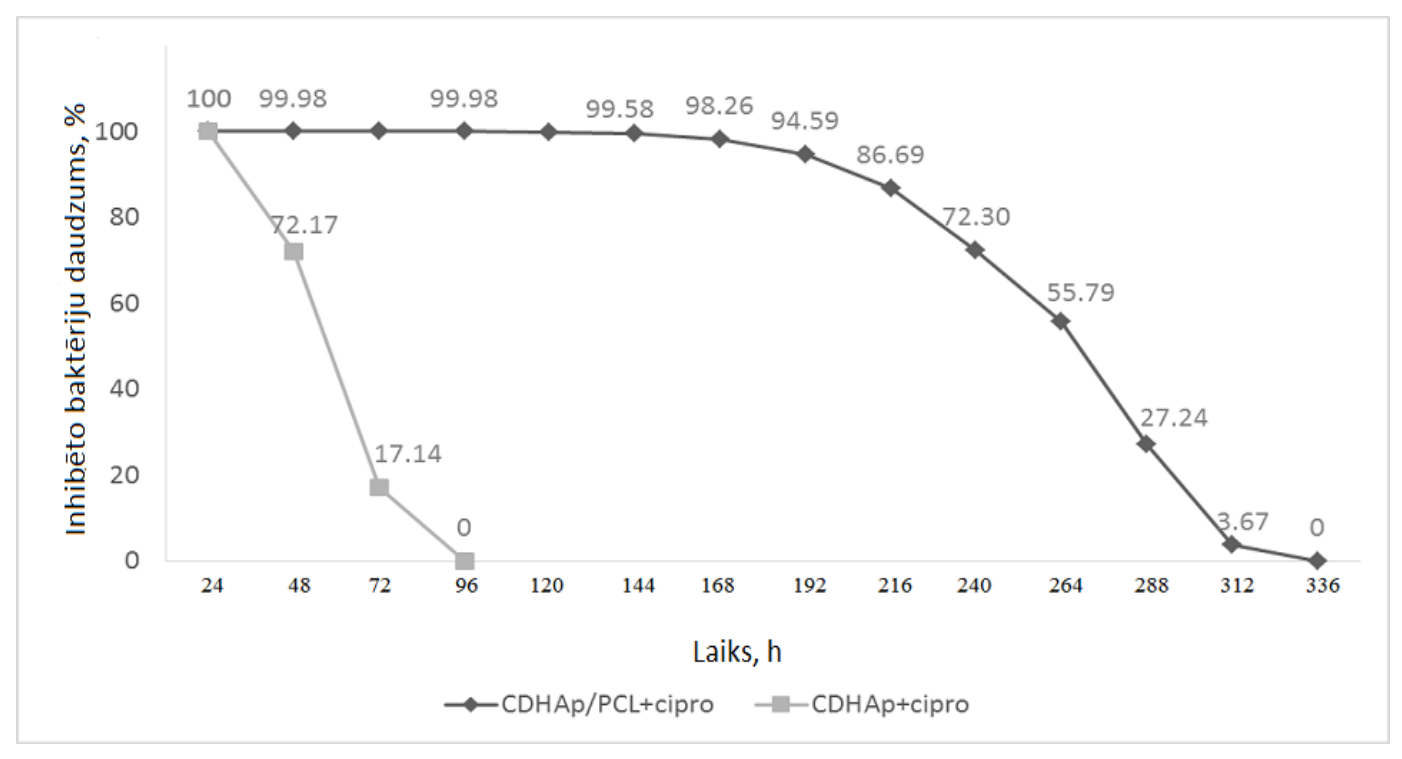

3.39. attēls. $\boldsymbol{P}$. aeruginosa augšanas inhibīcijas dinamika

Kā rāda $P$. aeruginosa augšanas inhibīcijas dinamika (3.39. attēls), tad antibiotiskās vielas no CDHAp/PCL+cipro izdalās pakāpeniski un pietiekami lielā daudzumā, lai 168 līdz 192 h ilgi inhibētu visas $P$. aeruginosa baktērijas. Pēc šīs laika atzīmes izdalīto antibiotisko vielu daudzums vairs nav pietiekams, lai nomāktu visas $P$. aeruginosa baktērijas, bet pēc 336 h antibakteriālās īpašības izzūd pavisam. CDHAp+cipro antibakteriālo īpašīibu zudums pret P. aeruginosa saskaņā ar Manna-Vitnija testu pētījuma laika posmā no $24 \mathrm{~h}$ līdz $48 \mathrm{~h}$ ir statistiski ticams $(p<0,05)$. Šādas izmaiņas nenovēro CDHAp/PCL+cipro materiālam (statistiski ticami neatšķiras, $\mathrm{p}>0,05$ ).

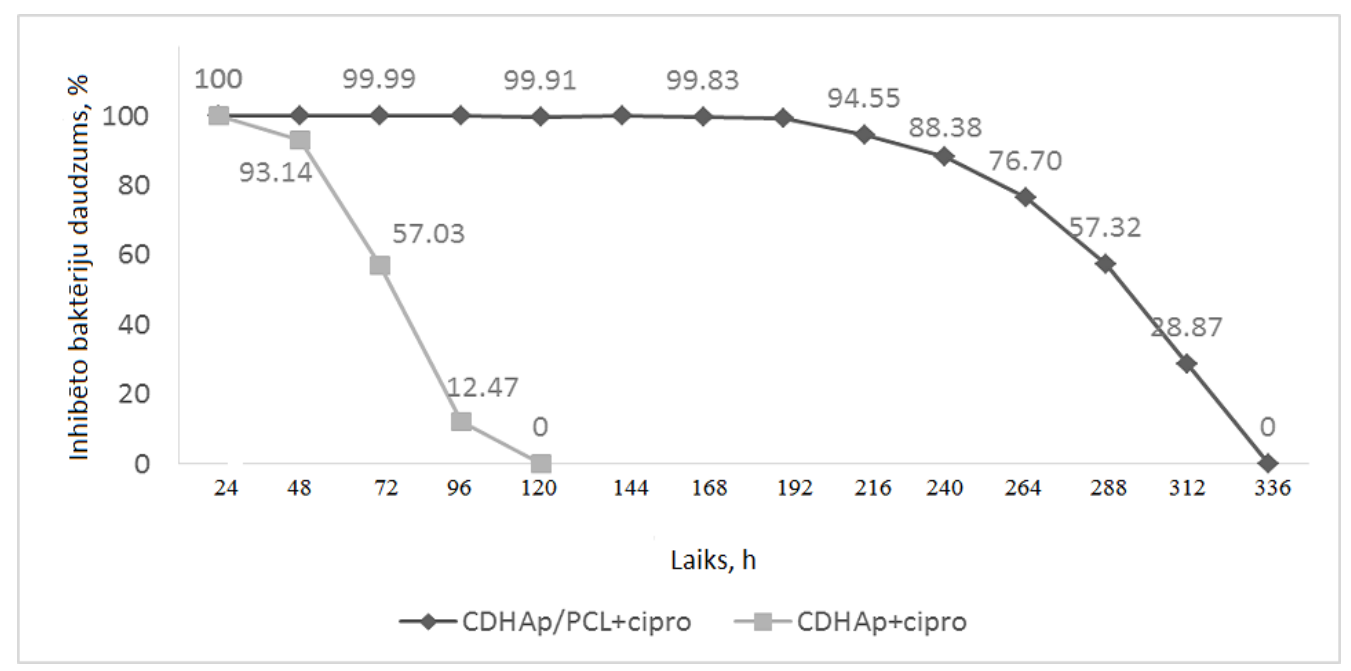

3.40. attēls. S. epidermidis augšanas inhibīcijas dinamika kompozītmateriāliem ar ciprofloksacīnu 
Salīdzinot CDHAp/PCL+cipro spēju inhibēt $P$. aeruginosa ar S. epidermidis augšanu (3.40. attēls), redzams, ka CDHAp/PCL+cipro nomāc lielāko daļu S. epidermidis ilgāku laika periodu nekā $P$. aeruginosa. Kopējais CDHAp/PCL+cipro antibakteriālais laiks pret S. epidermidis ir $304,8 \pm 11,59 \mathrm{~h}$, maksimālais antibakteriālais laiks $-312 \mathrm{~h}$, minimālais antibakteriālais laiks - 288 h. Starp CDHAp/PCL+cipro un CDHAp+cipro pret S. epidermidis novēro statistiski ticamas $(\mathrm{p}<0,001)$ atšķirības antibakteriālajā laikā.

\subsection{IL-10 ekspresijas intensitāte in vivo}

Kompozītmateriāliem - HAp/PLLA+genta, HAp/PLLA+cipro, HAp+genta un HAp+cipro, kas kontaminēti ar S. epidermidis, - neatkarīgi no izmeklējamo audu lokalizācijas attiecībā pret implantēto biomateriālu nenovēroja statistiski ticamas izmaiņas ( $\mathrm{p}>0,05$, Manna-Vitnija tests), salīdzinot ar kontroles grupu (3.41. attēls). Savukārt kompozītmateriāliem bez antibiotiskajām vielām (ciprofloksacīna vai gentamicīna), kas kontaminēti ar S. epidermidis baktēriju suspensiju, IL-10 intensitātes paaugstināšanos novēroja statistiski ticami ( $\mathrm{p}<$ 0,05, Manna-Vitnija tests) visos pētāmās grupas izmeklējamos audos, salīdzinot ar kontroles grupu. Lielākā IL-10 intensitāte tika noteikta audos, kuri tieši kontaktē ar implantēto HAp/PLLA kompozītmateriālu. Statistiski ticamas (p > 0,05, Manna-Vitnija tests) izmaiņas nenovēroja IL-10 intensitātes līmen̄̄ starp audiem, kas ir tiešā kontaktā ar biomateriāliem, un audiem, kas ir tiešā kontakta ārējā zonā. Distancēti no implantētā HAp/PLLA atrodošajos audos novēroja statistiski ticamu ( $p<0,05)$ IL-10 intensitātes samazinājumu, salīdzinot ar IL-10 intensitāti tiešā kontakta audos. Salīdzinot IL-10 intensitāti distancēti lokalizētajos audos ar kontroles grupas audiem, redzamas statistiski ticamas $(\mathrm{p}<0,05)$ atšksirības. 


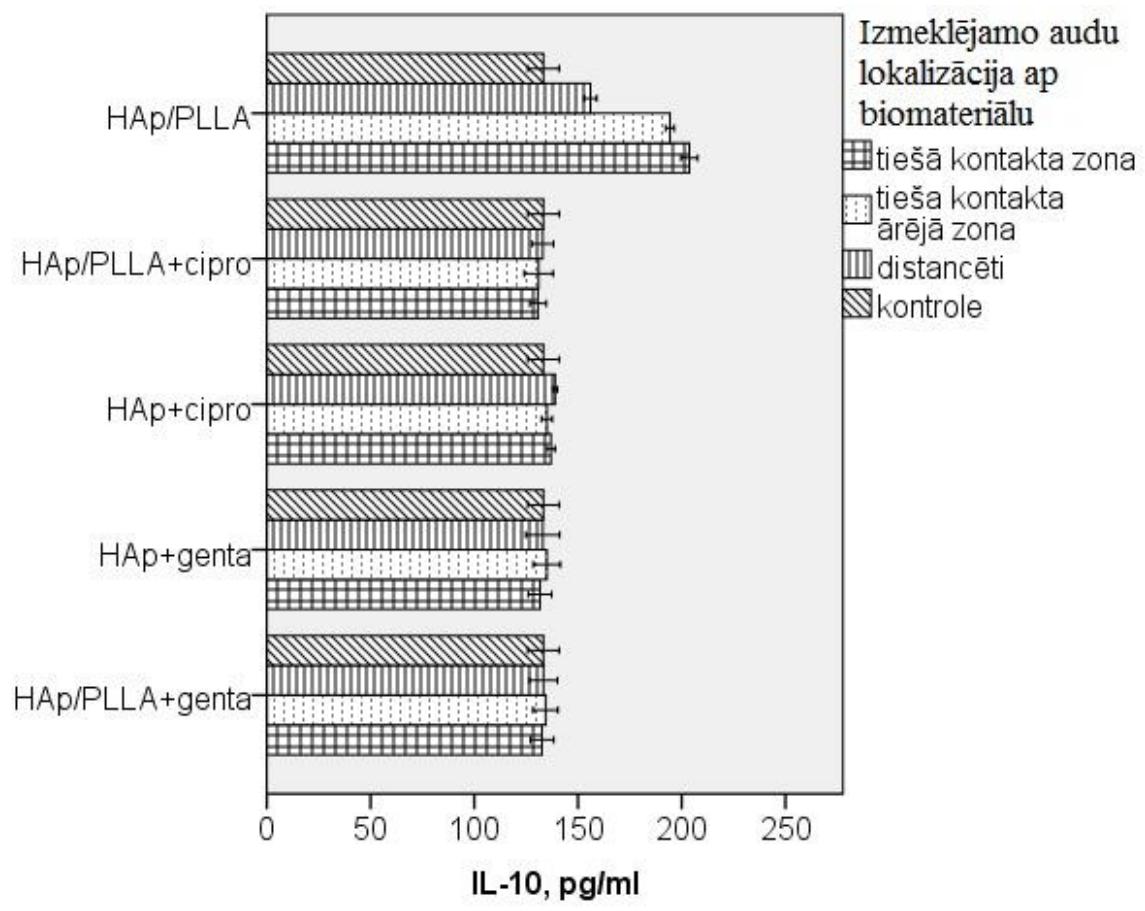

3.41. attēls. IL-10 ekspresijas intensitātes līmenis S. epidermidis kontaminācijas gadījumā

Kontaminējot HAp/PLLA+genta, HAp/PLLA+ciparo, HAp+genta un HAp+cipro ar $P$. aeruginosa baktēriju kultūru, neatkarīgi no izmeklējamo audu novietojuma ap biomateriālu netika novērotas statistiski ticamas atšķirības ( $\mathrm{p}>0,05)$ IL-10 ekspresijā (3.42. attēls).

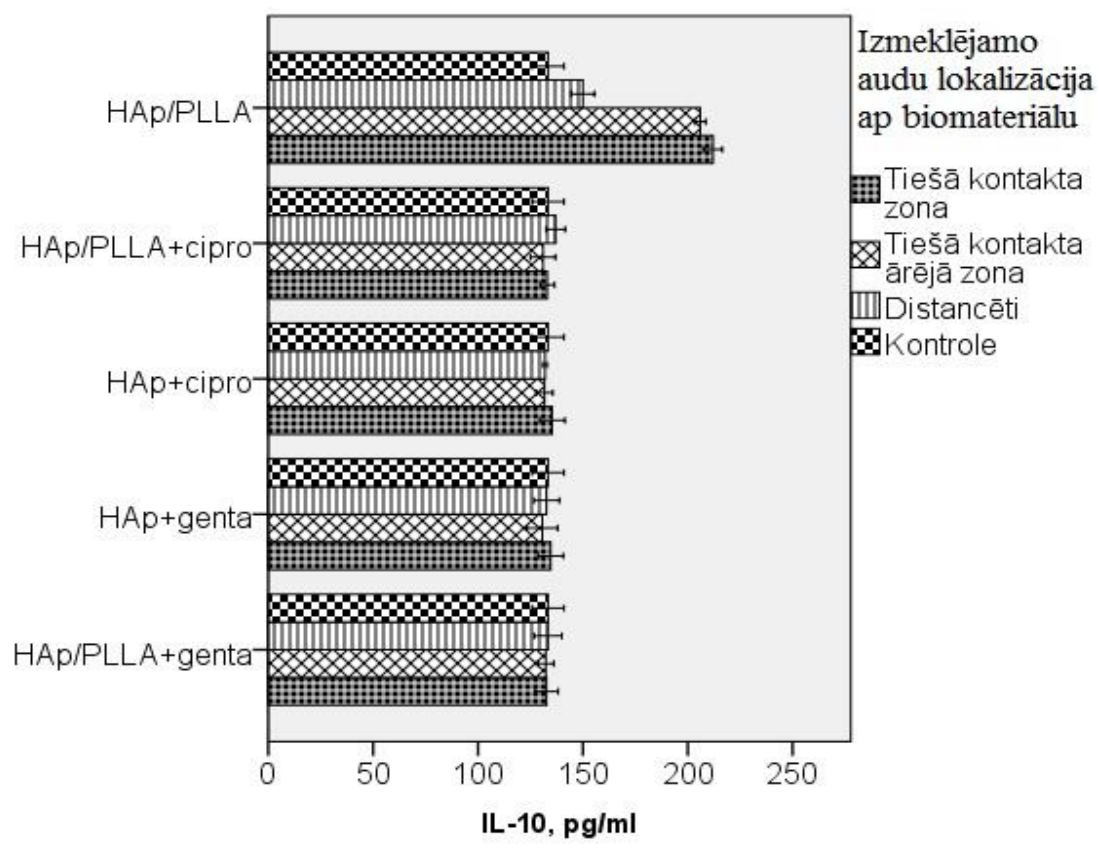

3.42. attēls. IL-10 ekspresijas intensitātes līmenis

$P$. aeruginosa kontaminācijas gadījumā 
Manna-Vitnija tests parādīja statistiski ticamas $(\mathrm{p}<0,05)$ IL-10 līmeņa atšķirības starp kontroles grupas un pārējiem izmeklējamiem audiem HAp/PLLA implantācijas un P. aeruginosa kontaminācijas gadījumā. Statistiski ticami $(\mathrm{p}<0,05)$ lielāka IL-10 intensitāte tika novērota tiešā kontakta audos - gan tieši kontaktējošos ar HAp/PLLA, gan tiešā kontakta arējā malā -, salīdzinot ar kontroles grupu, bet statistiski ticamas (p > 0,05) atšķirības starp abām (iekšējās un ārējās zonas) tiešā kontakta audu grupām netika atrastas. IL-10 intensitātes līmenis statistiski ticami $(\mathrm{p}<0,05)$ samazinās distancēti izmeklētajos audos, bet joprojām saglabājas statistiski ticamas $(\mathrm{p}<0,05)$ atšķirības ar izmeklēto kontroles grupu (veseliem dzīvniekiem bez biomateriāla implantācijas).

3.1. tabula

IL-10 līmenis pēc brūces kontaminācijas ar S. epidermidis (pg/ml)

\begin{tabular}{|c|c|c|c|c|}
\hline $\begin{array}{c}\text { Biomateriāla } \\
\text { paraugs }\end{array}$ & $\begin{array}{c}\text { Tiešā kontakta } \\
\text { iekšējā zona }\end{array}$ & $\begin{array}{c}\text { Tiešā kontakta } \\
\text { arējā zona }\end{array}$ & Distancēti & $\begin{array}{c}\text { Kontroles grupa } \\
\text { (bez } \\
\text { implantācijas un } \\
\text { brūces } \\
\text { kontaminācijas) }\end{array}$ \\
\hline HAp/PLLA+cipro & $131 \pm 4,04$ & $131 \pm 7,00$ & $133 \pm 5,29$ & $133 \pm 7,63$ \\
\hline HAp+cipro & $137 \pm 2,00$ & $135 \pm 2,64$ & $139 \pm 1,00$ & $133 \pm 7,63$ \\
\hline HAp/PLLA+genta & $133 \pm 5,69$ & $134 \pm 6,03$ & $133 \pm 7,64$ & $133 \pm 7,63$ \\
\hline HAp+genta & $132 \pm 5,69$ & $135 \pm 6,56$ & $133 \pm 8,19$ & $133 \pm 7,63$ \\
\hline HAp/PLLA & $204 \pm 4,04$ & $194 \pm 2,04$ & $156 \pm 3,00$ & $133 \pm 7,63$ \\
\hline
\end{tabular}

3.2. tabula

IL-10 līmenis pēc brūces kontaminācijas ar $P$. aeruginosa $(\mathrm{pg} / \mathrm{ml})$

\begin{tabular}{|c|c|c|c|c|}
\hline $\begin{array}{c}\text { Biomateriāla } \\
\text { paraugs }\end{array}$ & $\begin{array}{c}\text { Tiešā kontakta } \\
\text { iekšejā zona }\end{array}$ & $\begin{array}{c}\text { Tiešā kontakta } \\
\text { arējā zona }\end{array}$ & Distancēti & $\begin{array}{c}\text { Kontroles grupa } \\
\text { (bez } \\
\text { implantācijas un } \\
\text { brūces } \\
\text { kontaminācijas })\end{array}$ \\
\hline HAp/PLLA+cipro & $133 \pm 5,51$ & $132 \pm 3,79$ & $133 \pm 6,66$ & $133 \pm 7,63$ \\
\hline HAp+cipro & $135 \pm 6,03$ & $131 \pm 7,37$ & $133 \pm 6,11$ & $133 \pm 7,63$ \\
\hline HAp/PLLA+genta & $133 \pm 3,46$ & $131 \pm 6,00$ & $137 \pm 4,58$ & $133 \pm 7,63$ \\
\hline HAp+genta & $135 \pm 6,11$ & $132 \pm 4,04$ & $132 \pm 1,01$ & $133 \pm 7,63$ \\
\hline HAp/PLLA & $212 \pm 4,58$ & $206 \pm 2,64$ & $150 \pm 5,56$ & $133 \pm 7,63$ \\
\hline
\end{tabular}




\subsection{TNF-alfa ekspresijas intensitāte in vivo}

TNF-alfa intensitātes līmenis izmeklējamos audos gan S. epidermidis (3.43. attēls), gan P. aeruginosa (3.44. attēls) kontaminācijas gadījumā neizmainās un netiek novērotas statistiski ticamas $(\mathrm{p}>0,05)$ atšķirības ar kontroles grupu, ja tiek implantēti kompozītmateriāli ar antibiotiskajām vielām.

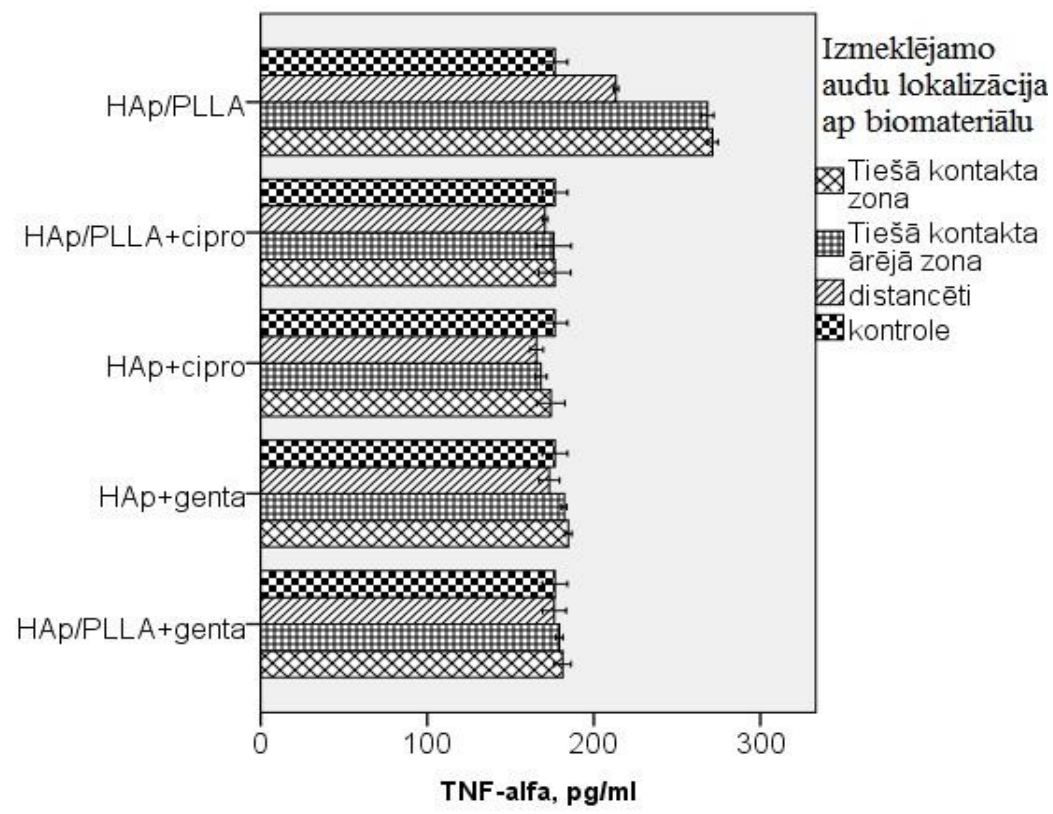

3.43. attēls. TNF-alfa ekspresijas intensitātes līmenis S. epidermidis kontaminācijas gadījumā

Intensīvāko TNF-alfa ekspresiju novēro tiešā kontaktā esošos audos ap HAp/PLLA, kas kontaminēts ar S. epidermidis vai P. aeruginosa (3.3. un 3.4. tabula). TNF-alfa ekspresija abu baktēriju kontaminācijas gadījumā ir statistiski ticami $(\mathrm{p}<0,001)$ intensīvāka, salīdzinot ar kontroles grupu. Ja HAp/PLLA tiek kontaminēts ar $P$. aeruginosa, novēro visintensīvāko TNF-alfa ekspresiju tiešā kontakta audos. Pēc TNF-alfa intensitātes no HAp/PLLA distancēti novietotajos audos var spriest, ka iekaisuma zona samazinās, jo abu baktēriju kultūru gadījumā novēro statistiski ticamu $(\mathrm{p}<0,05)$ atšķirību TNF-alfa intensitātē starp tiešā kontakta audiem un distancēti novietotajiem audiem. Iespējams, ka iekaisuma zona ir lielāka, ņemot vērā, ka TNF-alfa intensitātes līmenis abu baktēriju kultūru gadījumos distancēti novietotajos audos ir statistiski ticami $(\mathrm{p}<0,05)$ lielāks nekā kontroles grupai. 


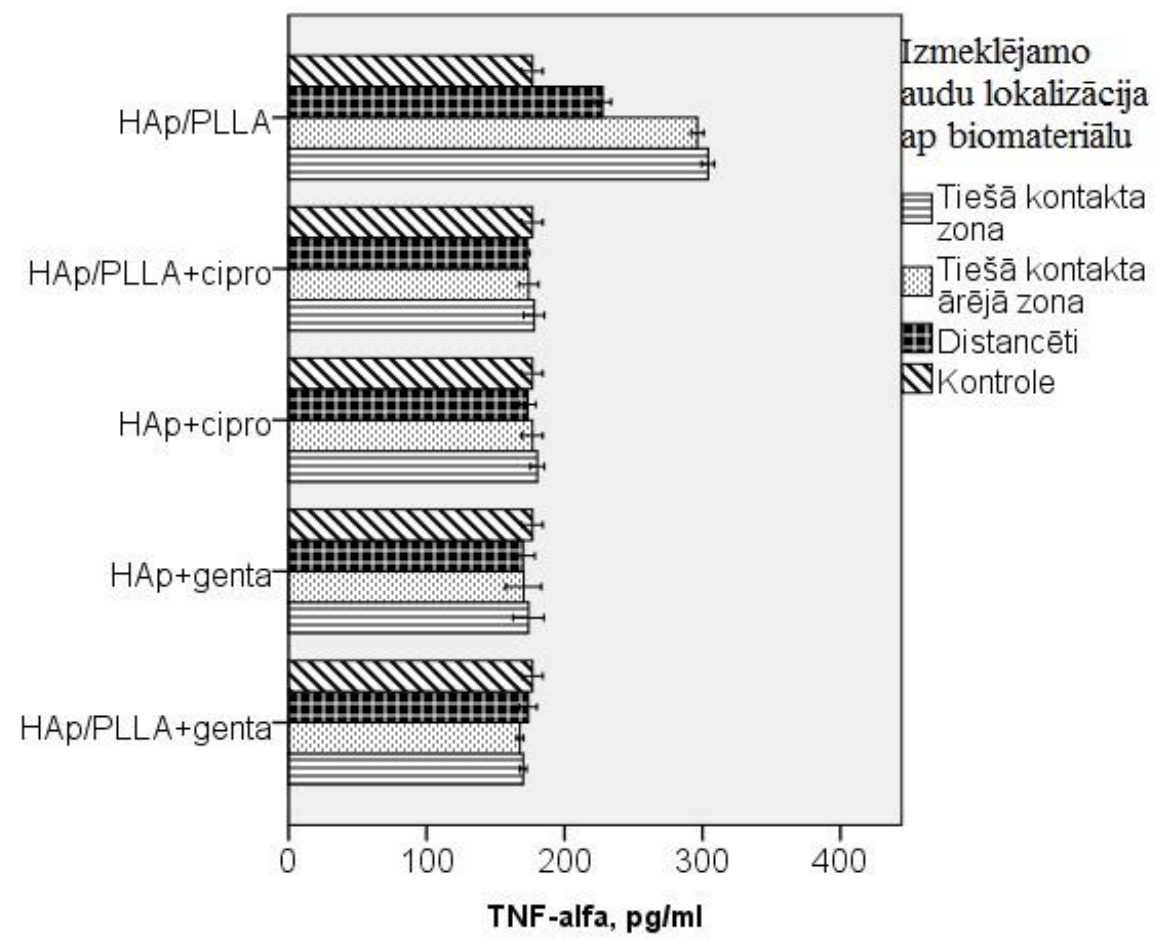

3.44. attēls. TNF-alfa ekspresijas intensitātes līmenis $P$. aeruginosa kontaminācijas gadījumā

TNF-alfa līmenis pēc brūces kontaminācijas ar S. epidermidis $(\mathrm{pg} / \mathrm{ml})$

\begin{tabular}{|c|c|c|c|c|}
\hline $\begin{array}{c}\text { Biomateriāla } \\
\text { paraugs }\end{array}$ & $\begin{array}{c}\text { Tiešā kontakta } \\
\text { iekšejjā zona }\end{array}$ & $\begin{array}{c}\text { Tiešā kontakta } \\
\text { arējā zona }\end{array}$ & Distancēti & $\begin{array}{c}\text { Kontroles grupa } \\
\text { (bez implantācijas } \\
\text { un brūces } \\
\text { kontaminācijas })\end{array}$ \\
\hline HAp/PLLA+cipro & $177 \pm 9,60$ & $176 \pm 10,5$ & $171 \pm 1,52$ & $177 \pm 7,63$ \\
\hline HAp+cipro & $174 \pm 8,38$ & $168 \pm 3,51$ & $166 \pm 4,04$ & $177 \pm 7,63$ \\
\hline HAp/PLLA+genta & $181 \pm 5,03$ & $179 \pm 2,08$ & $176 \pm 7,09$ & $177 \pm 7,63$ \\
\hline HAp+genta & $185 \pm 2,08$ & $182 \pm 1,53$ & $173 \pm 6,11$ & $177 \pm 7,63$ \\
\hline HAp/PLLA & $271 \pm 3,21$ & $268 \pm 3,78$ & $213 \pm 1,52$ & $177 \pm 7,63$ \\
\hline
\end{tabular}

3.4. tabula

TNF-alfa līmenis pēc brūces kontaminācijas ar $P$. aeruginosa $(\mathrm{pg} / \mathrm{ml})$

\begin{tabular}{|c|c|c|c|c|}
\hline $\begin{array}{c}\text { Biomateriāla } \\
\text { paraugs }\end{array}$ & $\begin{array}{c}\text { Tiešā kontakta } \\
\text { iekšejā zona }\end{array}$ & $\begin{array}{c}\text { Tiešā kontakta } \\
\text { arējā zona }\end{array}$ & Distancēti & $\begin{array}{c}\text { Kontroles grupa } \\
\text { bez implantācijas } \\
\text { un brūces } \\
\text { kontaminācijas })\end{array}$ \\
\hline HAp/PLLA+cipro & $178 \pm 7,54$ & $174 \pm 7,21$ & $173 \pm 2,00$ & $177 \pm 7,63$ \\
\hline HAp+cipro & $180 \pm 5,13$ & $177 \pm 7,63$ & $173 \pm 5,77$ & $177 \pm 7,63$ \\
\hline HAp/PLLA+genta & $170 \pm 2,65$ & $168 \pm 2,52$ & $174 \pm 6,43$ & $177 \pm 7,63$ \\
\hline HAp+genta & $174 \pm 11,14$ & $170 \pm 12,86$ & $170 \pm 8,66$ & $177 \pm 7,63$ \\
\hline HAp/PLLA & $271 \pm 3,21$ & $268 \pm 3,78$ & $213 \pm 1,52$ & $177 \pm 7,63$ \\
\hline
\end{tabular}




\subsection{Beta-defensīna-2 ekspresijas intensitāte in vivo}

Intensīvākā beta-defensīna-2 ekspresija notiek audos, kas ir visciešākajā kontaktā ar S. epidermidis kontaminētu HAp/PLLA (3.45. attēls); salīdzinot ar kontroles grupas betadefensīna-2 līmeni, novēroja statistiski ticamas izmaiņas $(\mathrm{p}<0,05)$. Starp tiešā kontakta ārējo un iekšējo audu zonu nenovēroja statistiski ticamas izmainas $(p>0,05)$. Statistiski ticamas $(\mathrm{p}<0,05)$ izmaiņas beta-defensīna-2 intensitātes līmenī novēro starp tiešā kontakta zonu un distancēti novietotajiem audiem HAp/PLLA implantācijas gadījumā, kas liecina par betadefensīna-2 intensitātes samazinājumu. Beta-defensīna-2 līmeņa izmaiṇas audos netika novērotas, implantējot kompozītmateriālu ar antibiotiskajām vielām.

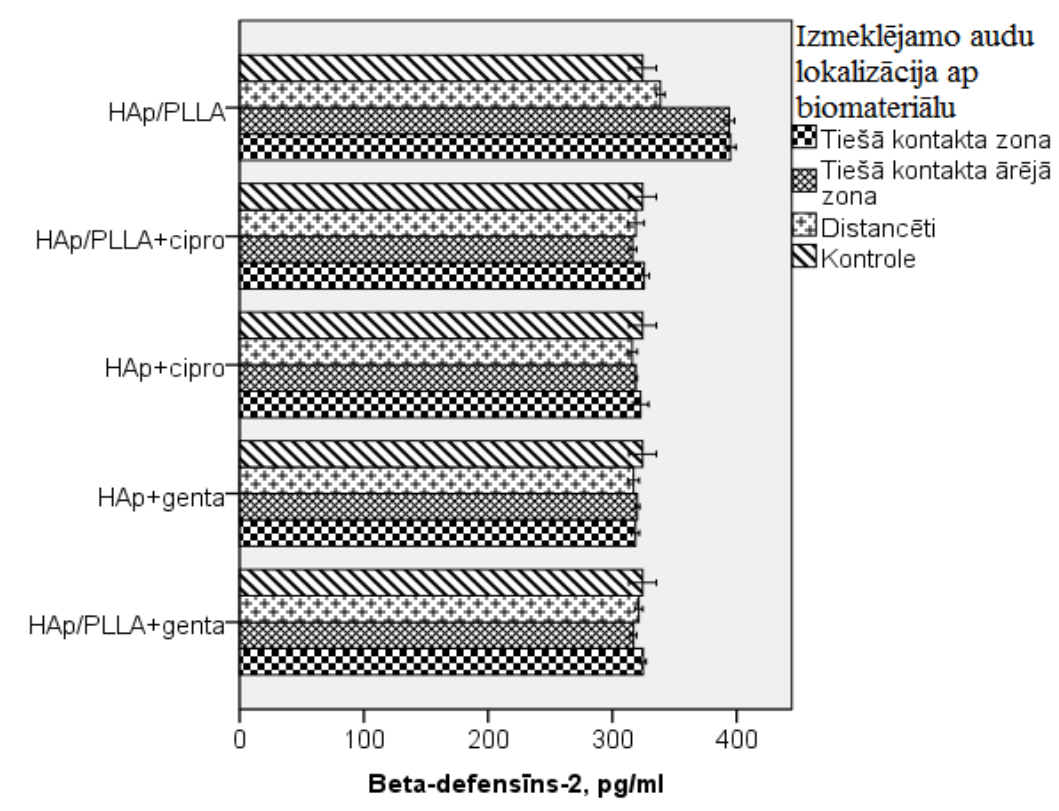

3.45. attēls. Beta-defensīna-2 ekspresijas intensitātes līmenis

S. epidermidis kontaminācijas gadījumā

Kontaminējot HAp/PLLA+cipro, HAp+cipro, HAp/PLLA+genta un HAp+genta ar P. aeruginosa, pēc 4 nedēḷu implantācijas nenovēroja beta-defensīna-2 līmeņa izmaiņas, salīdzinot ar kontroles grupu (3.46. attēls). Izmaiņas beta-defensīna-2 intensitātes līmenī novēroja audos pēc HAp/PLLA implantācijas un kontaminācijas ar P. aeruginosa. Līdzīgi kā $S$. epidermidis kontaminācijas gadījumā, ar̄̄ $P$. aeruginosa kontaminācijas gadījumā visintensīvāko beta-defensīna-2 ekspresiju novēroja tiešā kontakta audos ap HAp/PLLA. Beta-defensīna-2 intensitātes līmenis statistiski ticami $(\mathrm{p}<0,05)$ samazinās distancēti atrodošajos audos, salīdzinot ar tiešā kontakta audu zonu, bet nav statistiski ticama $(\mathrm{p}>0,05)$ atšķirība starp beta-defensīna-2 intensitātes līmeni distancēti novietotajos audos un kontroles grupu. 


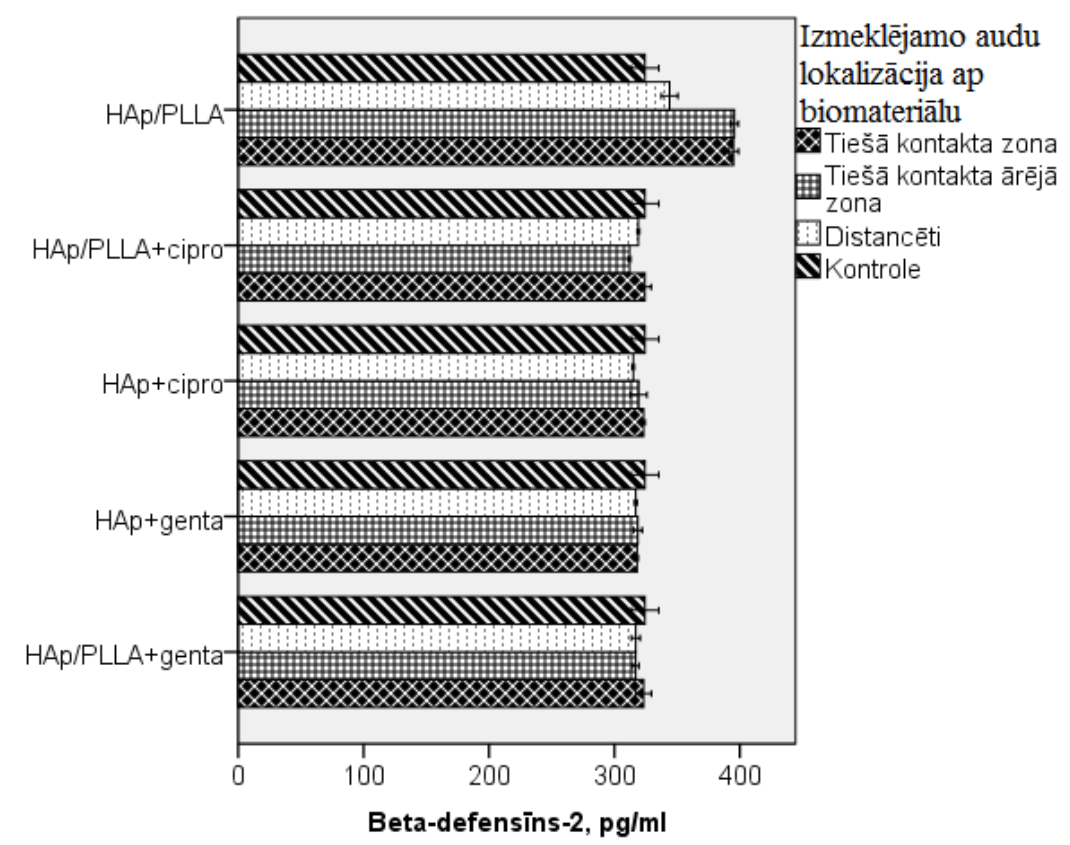

3.46. attēls. Beta-defensīna-2 ekspresijas intensitātes līmenis $P$. aeruginosa kontaminācijas gadījumā

Beta-defensīna-2 līmenis pēc brūces kontaminācijas ar $S$. epidermidis (pg/ml)

\begin{tabular}{|l|c|c|c|c|}
\hline \multicolumn{1}{|c|}{$\begin{array}{c}\text { Biomateriāla } \\
\text { paraugs }\end{array}$} & $\begin{array}{c}\text { Tiešā kontakta } \\
\text { iekšējā zona }\end{array}$ & $\begin{array}{c}\text { Tiešā kontakta } \\
\text { arējā zona }\end{array}$ & $\begin{array}{c}\text { Kontroles grupa } \\
\text { (bez implantācijas } \\
\text { un brūces } \\
\text { kontaminācijas) }\end{array}$ \\
\hline HAp/PLLA+cipro & $326 \pm 4,04$ & $316 \pm 3,21$ & $319 \pm 6,55$ & $324 \pm 11,01$ \\
\hline HAp+cipro & $323 \pm 6,24$ & $319 \pm 1,00$ & $316 \pm 4,00$ & $324 \pm 11,01$ \\
\hline HAp/PLLA+genta & $325 \pm 2,52$ & $317 \pm 2,65$ & $321 \pm 3,21$ & $324 \pm 11,01$ \\
\hline HAp+genta & $319 \pm 3,21$ & $320 \pm 2,00$ & $317 \pm 4,58$ & $324 \pm 11,01$ \\
\hline HAp/PLLA & $395 \pm 4,35$ & $394 \pm 4,35$ & $339 \pm 3,50$ & $324 \pm 11,01$ \\
\hline
\end{tabular}

Beta-defensīna-2 līmenis pēc brūces kontaminācijas ar $P$. aeruginosa (pg/ml)

\begin{tabular}{|l|c|c|c|c|}
\hline \multicolumn{1}{|c|}{$\begin{array}{c}\text { Biomateriāla } \\
\text { paraugs }\end{array}$} & $\begin{array}{c}\text { Tiešā kontakta } \\
\text { iekšējā zona }\end{array}$ & $\begin{array}{c}\text { Tiešā kontakta } \\
\text { arējā zona }\end{array}$ & $\begin{array}{c}\text { Distancēti } \\
\text { (bez implantācijas } \\
\text { un brūces } \\
\text { kontaminācijas) }\end{array}$ \\
\hline HAp/PLLA+cipro & $324 \pm 4,93$ & $312 \pm 1,00$ & $319 \pm 1,00$ & $324 \pm 11,01$ \\
\hline HAp+cipro & $323 \pm 1,12$ & $319 \pm 6,65$ & $315 \pm 1,00$ & $324 \pm 11,01$ \\
\hline HAp/PLLA+genta & $323 \pm 6,11$ & $317 \pm 2,65$ & $317 \pm 3,61$ & $324 \pm 11,01$ \\
\hline HAp+genta & $318 \pm 1,00$ & $319 \pm 3,51$ & $317 \pm 1,00$ & $324 \pm 11,01$ \\
\hline HAp/PLLA & $395 \pm 4,35$ & $394 \pm 4,35$ & $339 \pm 3,50$ & $324 \pm 11,01$ \\
\hline
\end{tabular}




\section{DISKUSIJA}

\subsection{Kompozītmateriālu efektivitāte in vitro}

Biomateriālu izmantošana medicīnā, lai aizvietotu orgāna vai tā daļu funkcijas, kḷūst arvien plašāka, lai nodrošinātu pacientu dz̄̄ves kvalitāti un ilgumu (piemēram, mākslīgais sirds vārstulis).

Gandrīz visās medicīnas nozarēs tiek izmantoti biomedicīniskie implantāti diagnostisko manipulāciju vai terapijas nolūkos - intravenozie un urīnpūšļa katetri, intubācijas aprīkojums, locītavu protēzes un cits biomedicīniskais aprīkojums. Taču, lietojot šos biomedicīskos implantātus, pastāv infekcijas attīstības risks (Huebsch et al., 2009).

Papildu infekcija, kas rodas blakus jau esošai saslimšanai, paildzina pacienta hospitalizācijas laiku, palielina ārstēšanas izmaksas un letalitātes risku. Biomateriālu saistītās infekcijas (BAI) attīstības risks visiem pacientiem nav vienāds; to nosaka vairāki faktori, kas saistīti ar pašu pacientu, implantanta veidu un operācijas apjomu. Gados vecākiem vai imūnsupresētiem pacientiem, pacientiem ar ļaundabīgo audzēju vai ar ādas bojājumiem ir lielāks BAI risks, jo šo pacientu imūnās sistēmas darbības spējas pret BAI ierosinātājiem ir samazinātas (Laupland et al., 2006; Goldmann et al., 1993, Greco et al., 2015).

BAI risku nosaka operācijas apjoms un operācijas vietas sterilitāte. Ortopēdisko operāciju laikā brūces apjoms ir liels, brūce var kalpot par baktēriju ieejas vārtiem, kam seko BAI attīstība. Operāciju zāles gaisa mikroflora, pacienta ādas un gḷotādas mikroflora un personāla mikroflora ir infekcijas izraisošo baktēriju avots (Vinh et al., 2005).

Zobu implantāntu un mutes dobumu operācijas notiek vidē, kurā ir atrodama viena no bagātākajām cilvēka normālajām mikroflorām. Lai arī šīs baktērijas pieder pie normālās cilvēka mikrofloras, tās vienlaicīgi ir oportūnistiskās baktērijas. Šādas ķirurgískās manipulācijas dod iespēju baktērijām ierosināt BAI (Heydenrijk et al., 2002).

Atsevišķu BAI attīstības risks nav liels, taču letalitātes risks ir augsts. Letalitātes risks ir atkarīgs no pacienta veselības stāvokḷa, infekcijas lokalizācijas un plašuma. Urīnceḷu infekcijas pēc urīnpūšļa katetrizācijas attīstās apmēram 30\% gadījumu, bet pacientu letalitāte šo infekciju dēḷ tiek vērtēta kā ļoti zema. Savukārt mākslīgo sirds vārstuḷu infekcijas attīstās 1-3\% gadījumu, bet pacientu letalitātes risks šo infekciju dēḷ ir vērtējams kā augsts (Darouiche et al., 2001, Wright et al., 2013).

Lai samazinātu BAI attīstības iespēju, slimnīcās pirms un pēc implantācijas operācijas tiek nozīmēta antibiotisko vielu terapija, kuras mērķis ir samazināt iespējamo oportūnisko 
baktēriju klātbūtni un iespēju ierosināt infekcijas, kā arī samazināt biomateriālu kontaminācijas risku operācijas laikā vai pēcoperācijas periodā (von Eiff et al., 2005).

Sistēmiskai antibiotisko vielu lietošanai ir vairāki trūkumi, salīdzinot ar lokālu antibiotisko vielu lietošanu. Viena no biežākajām problēmām ir disbakteriozes attīstība, kad tiek iznīcināta cilvēka normālā mikroflora kuṇǵa un zarnu traktā, mutes dobumā vai citās ķ̧ermeņa dal̦ās. Disbakterioze var kalpot kā veicinošs faktors citu baktēriju ierosinātām infekcijām, piemēram, C. difficile ierosinātam pseidomembranozam kolītam (Mylonakis et al., 2001, Aldrete Sdel et al., 2015).

Lietojot antibiotiskās vielas sistēmiski, tās mazā koncentrācijā nonāk audos visā cilvēka organismā. Mazā antibiotisko vielu koncentrācija ir iemesls normālās mikrofloras baktēriju un infekciju ierosinātāju baktēriju rezistences attīstībai pret antibiotiskajām vielām. Hepatotoksicitāte, nefrotoksicitāte, ototoksicitāte un citas komplikācijas ir sistēmisku antibiotisko vielu lietošanas rezultāts. Sistēmiskai antibiotisko vielu lietošanai ir limitētas iespējas gadījumos, ja pacientam pēc antibiotisko vielu lietošanas ir blakusparādības - slikta dūša, vemšana, alerǵiskas reakcijas, izsitumi utt. (Cunha et al., 2001; Soothill et al., 2015).

Lokālai antibiotisko vielu lietošanai ir noteiktas priekšrocības, it sevišşki biomateriālu implantācijas operāciju gadījumā, kad antibiotiskās vielas tiek izdalītas no biomateriāla, kas ir ar tām piesūcinātas(Gottenbos et al., 2002; Pritchard et al., 2013).

Šajā darbā galvenais uzdevums bija izpētīt ar antibiotiskajām vielām un bionoārdamiem polimēriem piesūcināta hidrosiapatīta antibakteriālās īpašības in vitro un to biosaderību in vivo pētījumā pēc biomateriāla implantācijas un kontaminācijas ar baktēriju kultūrām, nosakot iekaisuma citokīnu IL-10, TNF- $\alpha$ un antibakteriālā peptīda $\beta$-defensīna-2 intensitāti apkārtējos audos ap implantēto biomateriālu. Šo biomateriālu iespējamais pielietojums ir kaulaudu reǵenerācijā pacientiem ar BAI risku.

Hospitālī iegūto infekciju ierosinātāji ir gan starp gramnegatīvām (E. coli, P. aeruginosa, K. pneumoniae), gan starp grampozitīvām baktērijām ( $S$. aureus, S. epidermidis), un vairums no tām ir atrodamas ne tikai slimnīcas vidē, bet arī cilvēka normālajā mikroflorā. Retos gadījumos pētījumos tiek pārbaudīta biomateriālu pretsēnīšu darbība, un šim nolūkam tiek izvēlēts C. albicans vai kāds cits Candida gints pārstāvis, kuriem arī ir spēja ierosināt BAI. Daudzu autoru pētījumos ir norādes par plašo ierosinātāju daudzveidību. Viena pētījuma ietvaros tiek izmantotas vairākas baktēriju kultūras, lai pārbaudītu ar antibiotiskajām vielām piesūcinātu biomateriālu plašo antibakteriālo darbības spektru. Viena baktēriju kultūra pētījumos parasti tiek izvēlēta, ja baktērija ir biežākais kādas konkrētas saslimšanas ierosinātājs; tad tiek pārbaudīta potenciālā antibakteriālā darbība pret šo konkrēto ierosinātāju, lai novērstu saslimšanas attīstību, piemēram, S. aureus vai MRSA 
osteomielīta gadījumā. Grampozitīvo un gramnegatīvo baktēriju izmantošana viena pētījuma ietvaros tiek pamatota ar to, ka šīs baktērijas pārstāv cilvēka normālo mikrofloru, kas ierosina BAI (Peel et al., 2012; Vinh et al., 2005; von Eiff et al., 2005).

Lai izvērtētu pētījumā izmantoto Latvijā oriǵināli sintezēto biomateriālu antibakteriālās īpašības, tika izmantotas $S$. epidermidis un $P$. aeruginosa baktēriju kultūras. Šo baktēriju kultūru izvēle ir pamatota ar to, ka S. epidermidis ir viens no biežākajiem BAI, hospitālo infekciju un oportūnistisko infekciju ierosinātājiem. Augstā un plašā $P$. aeruginosa rezistence pret antibiotiskajām vielām, BAI un hospitālo infekciju ierosināšanas spēja pamato šīs baktēriju kultūras izmantošanu pētījumā.

Abām šīm baktēriju kultūrām ir raksturīgi vienlīdz aktīvi piesaistīties pie mākslīgo biomateriālu virsmām un veidot biofilmu. Tā kā biofilmu ierosināto infekciju ārstēšana ir sarežğìta un bieži nesekmīga, pētījumā tika izmantoti kompozītmateriāli ar antibiotiskajām vielām, kuri nomāktu gan baktēriju adhēziju, gan baktēriju kolonizāciju.

Literatūras dati liecina, ka tiek izmantoti dažādi kompozītmateriāli ar dažādām antibiotiskajām vielām. Antibiotisko vielu izvēle galvenokārt balstās uz antibiotisko vielu spektru pret biežākajiem multirezistentajiem ierosinātājiem. Ciprofloksacīns tiek izmantots pêtījumos, jo labi penetrē kaulaudos (Ahola et al., 2013). Atsevišşkos pētījumos autori priekšroku dod vankomicīna izmantošanai, jo tas uzrāda izcilas antibakteriālās īpašības pret gramnegatīvajām, grampozitīvajām un arī rezistentajām baktērijām (Liana et al., 2013). Lokālai un kontrolētai antibiotisko vielu izdalei pētījumos tiek izmantots arī gentamicīns (Loca et al., 2011), ceftriaksons (Kundu et al., 2010), cefaleksīns (Li et al., 2011), amoksicilīns (Xu et al., 2008), doksicilīns (Feng et al., 2010) un citas.

Šì pētījuma ietvaros hidroksiapatīts tika piesūcināts ar ciprofloksacīnu vai gentamicīnu. Tā kā S. epidermidis un $P$. aeruginosa ir dažādas šūnas sienas uzbūve, tad ir jāizmanto antibiotiskās vielas ar atšķirīgu darbības mehānismu. Pēc sava darbības mehānisma ciprofloksacīns un gentamicīns ir atšķirīgas antibiotiskās vielas, bet to darbības spektrā ir gan S. epidermidis, gan P. aeruginosa.

Analizējot literatūras datus, nav atrodams identisks pētījums par kompozītmateriālu antibakteriālajām īpašībām. Atrodami pētījumi, kuri atspoguḷo antibiotisko vielu izdali vai antibakteriālās îpašības līdzīgiem kompozîtmateriāliem ar mūsu pētījumā iekḷautajiem biomaterilaiem (Leprêtre et al., 2009; Loca et al., 2015; Kankilic et al., 2014). Pētījuma autoru antibiotisko vielu, baktēriju vai polimēru izvēle atšķiras. Taču mūsu pētījums un citu autoru pētījumus apvieno antibakteriālo īpašību salīdzināšana starp biomateriāliem ar bionoārdošos polimēru un bez polimēra. Ir atrodami daži pētījumi par IL-10, TNF- $\alpha$ un 
$\beta$-defensīna-2 ekspresiju apkārtējos audos pēc biomateriāla implantācijas (Gollwitzer et al., 2013; Ata-Ali et al., 2015; Reinis et al., 2011).

Mūsu pētījumā tika noskaidrots, ka HAp/PLLA+cipro antibakteriālās īpašības pret S. epidermidis saglabājas 278,4 $\pm 12,39$ h, bet CDHAp/PLLA+cipro - 213,6 $\pm 13,26$ h un CDHAp/PCL+cipro - 304,8 \pm 11,59 h . Biomateriāliem bez polimēra, bet ar antibiotiskajām vielām, antibakteriālais laiks pret $S$. epidermidis ir ievērojami īsāks nekā biomateriāliem ar polimēru, un ir 91,2 $\pm 10,11$ h HAp+cipro un $72 \pm 16$ h CDHAp+cipro.

Hidroksiapatītam, kas savienots ar ciklodekstrīna polimēru un ciprofloksacīnu, antibakteriālās īpašības pret $S$. aureus novēro līdz pat $240 \mathrm{~h}$, bet paraugiem bez polimēra antibakteriālais laiks pret $S$. aureus ir tikai 144 h. S. aureus izvēle šajā pētījumā tiek pamatota ar to, ka šì baktērija var būt rezistenta pret antibiotiskajām vielām un pēc savas šūnas sienas uzbūves ir gandrīz vienāda ar daudziem grampozitīviem BAI ierosinātājiem (Leprêtre et al., 2009). Citā pētījumā sterila S. aureus zona ap hidroksiapatītu ar PLLA un vankomicīnu tiek novērota 432 h. (Lian et al., 2013).

Mūsu pētījumā izmantotajam HAp/PLLA+cipro antibakteriālās īpašības pret P. aeruginosa ilgst 249,6 $\pm 13,39 \mathrm{~h}$, CDHAp/PLLA+cipro $-197 \pm 15,17 \mathrm{~h}$, bet CDHAp/PCL+cipro - 280,8 $\pm 16,19$ h. Līdzīgi kā pret $S$. epidermidis, biomateriāli bez polimēra pret $P$. aeruginosa uzrāda mazāku antibakteriālo laiku. HAp+cipro atibakteriālais laiks pret $P$. aeruginosa ir 69,6 7,58 h, CDHAp+cipro $-60 \pm 12,64 \mathrm{~h}$.

Kompozītmateriāls $\mathrm{PCL} / \beta-\mathrm{TCP}+$ cipro antibakteriālo aktivitāti pret $P$. aeruginosa uzrāda jau uzreiz pēc 2 h inkubācijas. Citi autori (piemēram, Ahola et al., 2013) pierāda , ka antibiotiskās vielas izdalās âtri, pat 2 h laikā pēc inkubācijas sākuma. Šajā gadījumā tika izmantota antibiotiskā viela - tetraciklīns, kas izdalījās no HAp/PCL kompozīta. Kopējo antibiotisko vielu izdales laiku no kompozītmateriāla ietekmē antibiotisko vielu daudzums izmantotajā kompozītmateriālā (Kim et al., 2004;). Ātrā antibiotisko vielu izdale no biomateriāla ir svarīga biofilmu veidošanās profilaksē uz tā virsmas. Pirmajās biofilmas veidošanās procesa stundās notiek baktēriju adhēzija pie biomateriāla, pēc kuras seko baktēriju proliferācija un biofilmas nobriešana. Antibiotiskajām vielām ātri izdaloties no biomateriāla, tiek inhibēta baktēriju adhēzija, tās nonāvējot. Baktēriju nespēja saistīties uz biomateriāla virsmas izslēdz biofilmas turpmākos veidošanās etapus.

Ortopēdisko infekciju ārstēšanā bez ciprofloksacīna tiek lietots arī vankomicīns. Šì antibiotiskā viela tiek lietota ārstēšanā gadījumos, ja ierosinātājs ir multirezistents pret antibiotiskajām vielām. Tāpēc vakcomicīnu izmanto biomateriālos ar ciklodekstrīna polimēru ilglaicīgai antibiotisko vielu izdalei. Šì kompozītmateriāla antibakteriālās īpašības pret 
S. aureus ilgst apmēram $144 \mathrm{~h}$, bet paraugiem bez ciklodekstrīna polimēra antibakteriālais ilgums ir tikai 96 h (Leprêtre et al., 2009).

Arī citi autori savos pētījumos ir pierādījuši bionoārdāmo polimēru ietekmi uz antibiotisko vielu izdales ātrumu un ilgumu. Piemēram, hidroksiapatīts ar PCL un vankomicīnu, salīdzinot ar hidrosiapatītu ar vankomicīnu bez PCL, vankomicīnu izdala ilgāk un pakāpeniski (Kim et al., 2005).

PLLA/ $\beta$-TCP ar vankomicīnu tiek rekomendēts izmantot pret MRSA, jo uzrāda labas antibakteriālās īpašības pret MRSA in vitro (Kankilic et al., 2011) un labas kaulaudu reǵenerācijas spējas pēc MRSA kontaminācijas in vivo (Kankilic et al., 2014), salīdzinot ar citiem biomateriālu paraugiem.

Modificētu kalcija fosfāta kaulu cementa biomateriālu ar PLLA un vankomicīnu spēja izdalīt antibiotiskās vielas ilgst līdz 43 dienām (Loca et al., 2015).

Pētījuma ietvaros nosakot hidroksiapatīta porainības līmeņa ietekmi uz antibakteriālo laiku, tika noskaidrots, ka zemākas porainības kompozītmateriālam $\downarrow$ HAp/PLLA+cipro antibakteriālais laiks pret $S$. epidermidis ir $151,2 \pm 16,19$ h un pret $P$. aeruginosa $-117,6 \pm$ 13,62 h. Zemākas porainības kompozītmateriālam bez bionoārdošā polimēra $\downarrow H A p+c i p r o$ antibakteriālais laiks pret $S$. epidermidis un P. aeruginosa ir tikai 52,8 $\pm 10,11 \mathrm{~h}$.

Citu autoru dati apstiprina kompozītmateriālu porainības ietekmi uz antibakteriālo laiku. Neatkarīgi no antibiotiskās vielas, kura tikusi izmantota pētījumā (ciprofloksacīns, gentamicīns, vankomicīns), mikroporainie hidroksiapatīiti saturēja vairāk antibiotisko vielu nekā blīvākie hidroksiapatīti. Antibakteriālais laiks pret pētījumā izmantotajām E. coli, $S$. aureus un $P$. aeruginosa baktēriju kultūrām visos trīs antibiotisko vielu gadījumos bija garāks, ja tika izmantoti mikroporaini hidroksiapatīti, nevis blīvākie. Piesūcināmo antibiotisko vielu koncentrācija ir atkarīga no poru izmēra un to procentuālā daudzuma. Palielinot kompozītmateriāla porainību, palielinās iespējamais piesūcināto antibiotisko vielu daudzums, bet, samazinot porainību, samazinās iespējamais piesūcināto antibiotisko vielu daudzums (Chai et al., 2007; Schnieders et al., 2011). Ir svarīgi atrast optimālo līdzsvaru starp porainību un antibiotisko vielu daudzumu, lai biomateriāls nodrošinātu pietiekami ilgstošas antibakteriālās īpašības, jo, palielinot porainības līmeni, hidrosiapatītam samazinās mehāniskās izturības spējas.

Mūsu pētījumā kompozītmateriāli ar gentamicīnu saglabā tādu pašu antibakteriālā laika tendenci kā kompozītmateriāli, kas piesūcināti ar ciprofloksacīnu. Neatkarīgi no tā, kāda antibiotiskā viela tiek izmantota, kompozītiem ar polimēru ir ilgākas antibakteriālās īpašības nekā bez polimēra. HAp/PLLA+genta antibakteriālais laiks pret S. epidermidis ir 249,6 \pm $16,78 \mathrm{~h}$, bet pret $P$. aeruginosa $-220,8 \pm 10,11$ h. Savukārt CDHAp/PCL+genta 
antibakteriālais laiks pret $S$. epidermidis ir 319,2 $\pm 16,19$ h, pret $P$. aeruginosa $-264 \pm 16 \mathrm{~h}$. CDHAp/PLLA+genta antibakteriālais laiks pret $S$. epidermidis ir 249,6 $\pm 16,78 \mathrm{~h}$, pret P. aeruginosa $-218,4 \pm 17,7$ h. Kompozītmateriāliem bez polimēra - HAp+genta, CDHAp+genta - antibakteriālais laiks pret S. epidermidis ir attiecīgi tikai $88,8 \pm 11,59 \mathrm{~h}$ un 67,2 $\pm 10,11$, pret $P$. aeruginosa attiecīgi $-67,2 \pm 10,11$ h un $52,8 \pm 10,11$ h. Šādus kompozītmateriālus ar antibiotiskajām vielām un polimēru var izmantot gadījumos, kad pacientiem ar osteomielītu ir vajadzīga kaulu aizvietošanas operācija un ir jānodrošina antibakteriāla iedarbība uz ierosinātāju, lai neattīstītos BAI (Ahola et al., 2013). Osteomielīta gadījumā lokālai antibakteriālai terapijai ir priekšrocības, salīdzinot ar sistēmisku antibakteriālo terapiju, jo kaulaudi ir slikti apasiņoti un līdz ar to jau tā mazā antibiotisko vielu koncentrācija iekaisuma perēklī nonāk vēl mazāk.

In vitro pētījumā izmeklētās kompozītmateriālu grupas ar antibiotiskajām vielām un polimēru uzrāda ilgākas antibakteriālās īpašības, kas osteomielīta gadījumā būtu piemērotākas. Lai gan dati ir iegūti in vitro pētījumā, pētījuma apstākḷi tiek nodrošināti līdzīgi, kādiem tiem būtu jābūt in vivo (tuvu cilvēka fizioloǵiskajiem apstākḷiem), līdz ar to iegūtos datus var attiecināt uz reāliem apstākḷiem in vivo.

Pētījumos, kur pret $S$. aureus ierosinātām saslimšanām tiek izmantots gentamicīns, redzams, ka hidrosiapatīta granulām ar gentamicīnu un keratīnu antibakteriālās īpašības pret S. aureus tiek novērotas 2904 h. Ir zināms, ka keratīnam piemīt stabilizējoša funkcija kompozītmateriālos, kas padara gentamicīna izdali no biomateriāla lēnāku. (Belcarz et al., 2009).

Pētījuma laikā visi kompozītmateriāli ar PCL neatkarīgi no izmantotās antibiotiskās vielas vai baktēriju kultūras uzrāda ilgākas antibakteriālās īpašības nekā kompozītmateriāli ar PLLA. Tas ir skaidrojams ar to, ka PLLA un PCL ir dažāds bionoārdīšanās ātrums, respektīvi, PCL noārdās lēnāk nekā PLLA (Tokiwa et al., 2009). Labvēlīgos vides apstākḷlos PLLA degradējas 1-2 nedēḷu laikā, bet, ja vides apstākḷi nav labvēlīgi, biodegradācija var ilgt pat gadu. Savukārt PCL biodegradācija notiek aptuveni 2 gadu laikā, bet tas ir atkarīgs no PCL sākotnējās molekulārās masas implantā, līdz ar to biodegradācijas laiks var būt arī īsāks (Armentano et al., 2010; Gunatillake et al., 2003). Pateicoties savam ilgajam biodegradācijas laikam, PCL tiek plaši izmantots lokālas antibiotisko vielu izdales sistēmās, jo tādējādi antibakteriālās īpašības tiek nodrošinātas ilgāk (Woodruff et al., 2009). Lielāks antibiotisko vielu daudzums, iespējams, tika izdalīts no kompozītmateriāliem ar PLLA pirmajās pētījuma dienās. Šis daudzums bija pietiekams, lai pilnībā nomāktu baktēriju augšanu. PCL kompozītmateriālu izdalītais antibiotisko vielu daudzums nebija tik liels kā PLLA 
kompozītmateriāliem, taču, tas bija pietiekams, lai pilnībā nomāktu baktēriju augšanu pirmajās pētījuma dienās.

Vairāki autori bez PLLA un PCL savos pêtījumos izmanto arī citus bionoārdošos polimērus, lai panāktu lokālu un vienmērīgu antibiotisko vielu izdalīšanos. Lielā polimēru daudzveidība un to daudzveidīgās īpašības autoriem l̦auj izvēlēties vajadzīgo polimēru pēc nepieciešamības. Piemēram, PLGA ir bionoārdošs polimērs, ko izmanto kompozītmateriālos, lai izdalītu antibiotisko vielu - gentamicīnu (Schnieders et al., 2006; Liet al., 2011). PLGA ar gentamicīnu 432 h uzrāda antibakteriālās īpašības pret S. aureus (McLaren et al., 2014).

Pateicoties ciprofloksacīna efektivitātei gan pret grampozitīvām, gan gramnegatīvām baktērijām, tas tiek izmantots daudzos pētījumos, lai nodrošinātu biomateriālu antibakteriālās īpašības un samazinātu BAI risku.

In vitro pētîjumi liecina, ka ciprofloksacīns spēj labi darboties, adsorbēts uz biomateriāliem. Pētījumos (piemēram, Parwe et al., 2014) arī konstatēts, ka ar ciprofloksacīnu pārklātas PLLA nanošķiedras uzrāda antibakteriālo aktivitāti pret $S$. aureus jau pēc $24 \mathrm{~h}$ inkubācijas $37{ }^{\circ} \mathrm{C}$ temperatūrā, un, lai pret $S$. aureus sasniegtu līdzīgu efektivitāti, tīra ciprofloksacīna koncentrācijai ir jābūt 8 reizes augstākai nekā tad, ja tas ir adsorbēts uz PLLA nanošķiedrām. Labākas antibakteriālās īpašības pret $E$. coli ir uzrādījušas PLLA nanošķiedras, kas pārklātas ar ciprofloksacīnu (Parwe et al., 2014).

Kohleārais implants ar ciprofloksacīnu 5 nedēḷas saglabā antibakteriālās īpašīibas pret S. pneumoniae in vitro apstākļos $23{ }^{\circ} \mathrm{C}$ un $37^{\circ} \mathrm{C}$ temperatūrā. Savukārt in vivo pētījumos ir konstatēts, ka kohleārais implants ar ciprofloksacīnu pasargā žurkas no S. pneumoniae meningīta, kas varētu būt iegūts hematogēnā cel̦ā. Kontaminējot šo implantu ar baktērijām tieši vidusausī, meningīts attīstìjās pēc garāka inkubācijas perioda (Wei et al., 2006).

Polimerizētas nanosfēriskas kontaktlēcas ar ciprofloksacīnu līdz pat 96 stundām spēj inhibēt S. aureus un P. aeruginosa augšanu (Garhwal et al., 2012).

Ciklodekstrīna kombinācija ar ciprofloksacīnu paildzina biomateriālu antibakteriālās īpašības pret S. aureus, S. epidermidis un E. coli (Laurent et al., 2011).

Gentamicīna teicamās antibakteriālās īpašības pret gramnegatīvajām baktērijām ir iemesls, kāpēc šī antibiotiskā viela tiek plaši lietota biomateriālos.

Izmantojot gentamicīnu antibakteriālo biomaterālu izveidē, ir svarīgi noteikt tā termostabilitāti. Kaula rekonstrukcijā izmantojamo biomateriālu, kas pārklāts ar gentamicīnu, pirms kaulu rekonstrukcijas iespējams uzglabāt sasaldētā veidā. Saskaṇā ar pētījumu (piemēram, Coraça-Huber et al., 2013) datiem, gentamicīna atbrīvošanās no protēzes $-20{ }^{\circ} \mathrm{C}$ un $-80{ }^{\circ} \mathrm{C}$ temperatūrā bija samērā līdzīga. Gentamicīna šķīdumu pakḷaujot $50{ }^{\circ} \mathrm{C}$ iedarbībai 30 minūtes, $77,91 \%$ gentamicīna tiek degradēts, un tas liecina par zemo termostabilitāti un 
ierobežo tā izmantošanu. Gentamicīnu plaši lieto antibakteriālo biomateriālu izveidē, jo tam ir plašs darbības spektrs, turklāt cilvēka organisma temperatūra ir optimāla gentamicīna darbībai (Naveed et al., 2014).

Ar gentamicīnu klāts sintētiskais trūces tīklinšs in vitro pētījumos uzrāda augstas antibakteriālās īpašības pret $S$. aureus, tādējādi pasargājot pacientu no iespējamās postoperatīvās infekcijas (Wiegering et al., 2014). Tāpat pētījumos konstatēts, ka pēc asinsvadu implantu ievietošanas aptuveni $20 \%$ pacientu attīstās ar operāciju saistīta infekcija, taču asinsvadu kolagēna implants, kas klāts ar gentamicīnu, pēc operācijas nodrošina pilnīgu antibakteriālo aktivitāti. Pacientiem, kuriem izmantots implants ar gentamicīnu, novērots īsāks hospitalizācijas laiks (Costa Almeida et al., 2014).

Izteiktu antibakteriālo efektivitāti gentamicīns uzrāda arī ortopēdisko biomateriālu sastāvā. Ar gentamicīnu pārklātam kaula cementam ir izteikti ilgākas antibakteriālās īpašības pret S. aureus, MRSA, koagulāzes negatīvajiem stafilokokiem, E. coli, P. aeruginosa un Klebsiella spp. nekā cementam, kas klāts ar citām antibiotiskām vielām, piemēram, vankomicīnu, piperacilīnu vai imipenemu (Chang et al., 2013). Papēža kaula hroniska osteomielīta ārstēšana, izmantojot ar gentamicīnu piesūcinātu kalcija fosfāta cementu, ir sekmīga arī diabēta slimniekiem (Iwakura et al., 2014). Pacientiem, kuriem izmantoja gentamicīna polimetilmetakrilāta cementu kaula reǵenerācijai, novēroja gentamicīna izdalīšanos urīnā vidēji no 43 līdz 71 dienai (Webb et al., 2013).

\subsection{Iekaisumu citokīnu ekspresija in vivo}

Pētījuma in vivo sadaļā tika noteikta iekaisuma citokīnu (TNF- $\alpha$ un IL-10) un antibakteriālo peptīdu ( $\beta$-defensīns-2) ekspresija apkārtējos audos pēc četru nedēḷu HAp/PLLA+cipro, HAp/PLLA/+genta, HAp+cipro, HAp+genta un HAp/PLLA zemādas implantācijas un implanta kontaminācijas ar S. epidermidis vai P. aeruginosa.

Iekaisuma citokīnu produkcija ir organisma atbildes reakcija pret implantēto biomateriālu vai biomateriāla bakteriālo kontamināciju. Palielināta iekaisuma citokīnu daudzuma atrade var kalpot par diagnostisko kritēriju biomateriālu infekcijas gadījumā (Franz et al., 2011).

HAp/PLLA+cipro, HAp/PLLA/+genta, HAp+cipro un HAp+genta implantācijas un tai sekojošas bakteriālas kontaminācijas (neatkarīgi no tā, kāda baktēriju kultūra tika izmantota) apkārtējos audos ap biomateriālu netika novērotas TNF- $\alpha$, IL-10 un $\beta$-defensīna-2 ekspresijas izmaiņas. Neatkarīgi no tā, vai PLLA bija vai nebija biomateriālā, audos netika atrastas izmaiņas, salīdzinot ar kontroles grupu. Normālais iekaisuma citokīnu un antibakteriālo 
peptīdu daudzums liecina par to, ka pēc šo kompozītmateriālu implantācijas un kontaminācijas nav veidojies iekaisuma process, kas saistāms ar antibiotisko vielu izdali no biomateriāla un baktēriju iznīcināšanu. Baktēriju daudzums, kas tika izmantots in vivo pētījumā, bija pietiekami mazs, lai kompozītmateriāli ar un bez polimēra spētu baktērijas iznīcināt pilnībā, ko pierāda in vitro pētījuma sadaḷa.

Pretēja situācija ir HAp/PLLA implantācijas un baktēriju kontaminācijas gadījumā. Pēc četru nedēḷu implantācijas apkārtējos audos ekspresējas palielināts TNF- $\alpha$, IL-10 un $\beta$-defensīna-2 daudzums, kas skaidri liecina par iekaisuma procesu. Ņemot vērā, ka šis kompozītmateriāls nav piesūcināts ar antibiotiskām vielām, izmantotais baktēriju daudzums ir pietiekams, lai attīstîtos iekaisuma process.

Vairāki autori implantu infekciju gadījumā audos ap implantu ir novērojuši palielinātu IL-10 un TNF- $\alpha$ līmeni, salīdzinot ar implantiem bez infekcijas (Duarte et al., 2009). Šos rezultātus apstiprina citu autoru pētījumi, kuros pētīti audi ap dentāliem implantiem iekaisuma gadījumā, salīdzinot ar veseliem audiem ap dentālo implantu (Ata-Ali et al., 2015).

Staphylocuccus spp. ierosināto locītavu implantu infekciju gadījumā locītavu somiṇas šķidrumā ir atklāts paaugstināts TNF- $\alpha$ un $\beta$-defensīna-2 līmenis, kā arī paaugstināts vēl cita antibakteriālā peptīda - $\beta$-defensīna-3 - līmenis (Gollwitzer et al., 2013).

Intensīvāka TNF- $\alpha, \beta$-defensīna-2 un IL-10 produkcija audos ap biomateriālu ir novērota pēc kompozītmateriālu zemādas implantācijas un kontaminācijas ar $P$. aeruginosa vai S. epidermidis (Reinis et al., 2011). Biomateriāli, kas tikuši izmantoti pētījumā, ir bez antibiotiskajām vielām un kontaminēti ar mazāku baktēriju daudzumu nekā mūsu pētījumā, bet arī šāda baktēriju koncentrācija ir pietiekama, lai stimulētu iekaisuma citokīnu un antibakteriālo peptīdu produkciju ap biomateriāla audiem.

Neizmainīts TNF- $\alpha$ līmenis, salīdzinot ar kontroles grupu, tiek novērots gadījumos, kad lokāls vaskulārs implants ar vankomicīnu tiek kontaminēts ar MRSA. Šāds pats implants bez vankomicīna, bet kontaminēts ar baktēriju kultūru, izraisa palielinātu TNF- $\alpha$ produkciju (Gul et al., 2011). 


\section{SECINĀJUMI}

1. Biomateriāliem ar antibiotiskām vielām un ar bionoārdošo polimēru pārklājumu piemīt izteiktas antibakteriālās īpašības; antibiotiskās vielas izdalās pakāpeniski un saglabājas ilgāk nekā biomateriāliem bez bionoārdošā polimēra pārklājuma, kuri antibiotiskās vielas izdala īslaicīgi.

2. Visu pētījumā iekḷauto biomateriālu (ar un bez polimēru pārklājuma) antibakteriālās darbības laiks pret $S$. epidermidis ir ilgāks nekā tādiem pašiem biomateriāliem pret P. aeruginosa; tas konstatēts, izmantojot divas dažādas antibakteriālās testēšanas metodes.

3. Biomateriāliem ar antibiotiskajām vielām un PCL polimēru savienojumu antibakteriālās īpašības ir ilgstošākas nekā tādiem pašiem biomateriāliem ar PLLA (neatkarīgi no antibiotisko vielu veida vai baktēriju kultūras).

4. Ar antibiotiskajām vielām un ar polimēru savienotu zemas porainības biomateriālu antibakteriālais laiks pret $S$. epidermidis un $P$. aeruginosa ir issāks nekā identiskiem biomateriāliem ar lielāku porainību.

5. Iekaisuma citokīnu un antibakteriālo peptīdu ekspresija audos ap biomateriālu ar antibiotiskajām vielām un kontaminētu ar $S$. epidermidis un $P$. aeruginosa pēc implantācijas neatkarīgi no antibiotiskās vielas nemainās.

6. Palielināta iekaisuma citokīnu un antibakteriālo peptīdu izdales intensitāte ir novērojama audos ap kontaminētu, bet antibiotiskās vielas nesaturošu biomateriālu. 


\section{PUBLIKĀCIJAS PAR PĒTĪJUMA TĒMU}

\section{Raksti starptautiski citējamās datubāzēs}

1. Skadins I., Kroica J., Salma I., Reinis A., Sokolova M., Rostoka D. The level of inflammatory cytokines and antimicrobial peptides after composite material implantation and contamination with bacterial culture. // Key Engineering Materials, 2017; 721: 245250.

2. Narkevica I., Reinis A., Bugovecka L., Skadins I., Sansonetti E., Kroica J., Ozolins J. In vitro bioactivity and bacteriostasis effect of thermally treated and UV-light irradiated $\mathrm{TiO}_{2}$ ceramics. // Key Engineering Materials, 2016; 674: 121-126.

3. Brangule A., Gross K. A., Skadins I., Reinis A., Kroica J. Simultaneous identification of amorphous calcium phosphate and S.epidermidis bacteria by photoacoustic spectroscopy. // Key Engineering Materials, 2017; 720: 125-129.

4. Kroica J., Skadins I., Salma I., Reinis A., Sokolova M., Rostoka D., Berza N. Antibacterial efficiency of hydroxyapatite biomaterials with biodegrable polylactic acid and polycaprolactone polymers saturated with antibiotics. // Proceedings of the Latvian Academy of Sciences, Section B, 2016; 4(703): 20-30.

\section{Starptautiska mēroga uzstāšanās par publikācijas tēmu}

1. Skadins I., Reinis A., Kroica J. Analysis methods of antibacterial efficiency of retainers impregnated with antibiotics. // Symposium Bioceramics and cells for reinforcement of bone (October 18-20, 2012, Riga, Latvia).

2. Skadins I., Kroica J., Salma I., Reinis A., Sokolova M., Berza N. Antibacterial efficiency of hydroxyapatite biomaterials with biodegradable polylactic acid polymer, saturated with ciprofloxacin. // Scandinavian Society for Biomaterials $-7^{\text {th }}$ Annual Meeting iNANO (Aarhus University, Aarhus, Denmark, March 26-28, 2014).

3. Skadins I., Kroica J., Salma I., Reinis A., Sokolova M., Rostoka D., Berza N. Antibacterial efficiency of biomaterials with open porosity of $15 \%$ and total porosity of 20\%. // European Orthopaedic Research Society $22^{\text {nd }}$ Annual Meeting (2-4 July, Nantes, France).

4. Skadins I., Kroica J., Salma I., Reinis A., Sokolova M., Rostoka D., Berza N. Biomaterials with biodegradable polymer and antibiotics - efficiency tests in laboratories, practical use, advantages and disadvantages. // $12^{\text {th }}$ Baltic Congress of Laboratory Medicine (Latvia, Riga, September 18-20, 2014). 
5. Skadins I., Kroica J., Salma I., Reinis A., Sokolova M., Rostoka D., Berza N. Antibacterial efficiency of hydroxyapatite biomaterials with biodegradable polycaprolactone polymer, saturated with ciprofloxacin. $/ / 2^{\text {nd }}$ Congress of Baltic Microbiologists (Tartu, Estonia, 16.10.2014-19.10.2014).

6. Skadins I., Kroica J., Salma I., Reinis A., Sokolova M., Rostoka D. Antibacterial effiency of biomaterials with biodegradable polymer and antibiotics. // Scandinavian Society for Biomaterials $-8^{\text {th }}$ conference (Sigulda, Latvia, 6-8 May 2015).

\section{Starptautiska mēroga tēzes par pētījuma tēmu}

1. Skadins I., Kroica J., Salma I., Reinis A., Sokolova M., Berza N. Antibacterial efficiency of hydroxyapatite biomaterials with biodegradable polylactic acid polymer, saturated with ciprofloxacin. // Scandinavian Society for Biomaterials $-7^{\text {th }}$ Annual Meeting iNANO (Aarhus University, Aarhus, Denmark, 26-28 March 2014), O19.

2. Skadins I., Kroica J., Salma I., Reinis A., Sokolova M., Rostoka D., Berza N. Antibacterial efficiency of hydroxyapatite biomaterials with biodegradable polylactic acid polymer, saturated with gentamicin. // $24^{\text {th }}$ European Congress of Clinical Microbiology and Infectious Diseases (in Barcelona, Spain, 10-13 May 2014), p. 016.

3. Skadins I., Kroica J., Salma I., Reinis A., Sokolova M., Rostoka D., Berza N. Antibacterial efficiency of biomaterials with open porosity of $15 \%$ and total porosity of 20\%. // European Orthopaedic Research Society 22 ${ }^{\text {nd }}$ Annual Meeting (2-4 July, Nantes, France), O2.3.

4. Skadins I., Kroica J., Salma I., Reinis A., Sokolova M., Rostoka D., Berza N. Biomaterial antibacterial efficiency with reduced level of porosity. // European Orthopaedic Research Society $22^{\text {nd }}$ Annual Meeting (2-4 July, Nantes, France), p. 7.1.

5. Skadins I., J Kroica J., Salma I., Reinis A., Sokolova M., Rostoka D., Berza N. Antibacterial efficiency of hydroxyapatite biomaterials with biodegradable polycaprolactone polymer, saturated with gentamicin. // $12^{\text {th }}$ Baltic Congress of Laboratory Medicine (Latvia, Riga, September 18-20, 2014), p. 42.

6. Skadins I., J Kroica J., Salma I., Reinis A., Sokolova M., Rostoka D., Berza N. Biomaterials with biodegradable polymer and antibiotics - efficiency tests in laboratories, practical use, advantages and disadvantages. // $12^{\text {th }}$ Baltic Congress of Laboratory Medicine (Latvia, Riga, September 18-20, 2014), p. 41.

7. Skadins I., J Kroica J., Salma I., Reinis A., Sokolova M., Rostoka D., Berza N. Antibacterial efficiency of hydroxyapatite biomaterials with biodegradable 
polycaprolactone polymer, saturated with ciprofloxacin. $/ / 2^{\text {nd }}$ Congress of Baltic Microbiologists (Tartu, Estonia, 16.10.2014-19.10.2014), p. 54.

8. Skadins I., J Kroica J., Salma I., Reinis A., Sokolova M., Rostoka D. Antibacterial effiency of biomaterials with biodegradable polymer and antibiotics. // Scandinavian Society for Biomaterials $-8^{\text {th }}$ conference (Sigulda, Latvia, 6-8 May 2015), p. 49. 


\section{Latvijas mēroga uzstāšanās par promocijas darba pētījuma tēmu}

1. Skadins I., J Kroica J., Salma I., Reinis A., Sokolova M., Rostoka D., Berza N. Hidroksiapatīta-polipienskābes-ciprofloksacīna biomateriālu ar vidējo atvērto porainību 15\% antibakteriālās efektivitātes noteikšana, izmantojot Kirby-Bauer difūzijas metodi. // RSU Zinātniskā konference (2014. gada 10.-11. aprīlis).

\section{Latvijas mēroga tēzes par pētījuma tēmu}

1. Skadins I., J Kroica J., Salma I., Reinis A., Sokolova M., Rostoka D., Berza N. Biomateriālu efektivitāte pret Ps. aeruginosa un S. epidermidis. // RSU Zinātniskā konference: Tēzes (2014. gada 10.-11. aprīlis). Rīga: RSU, 2014, 337. lpp.

2. Skadins I., J Kroica J., Salma I., Reinis A., Sokolova M., Rostoka D., Berza N. Biomateriālu antibakteriālās efektivitātes noteikšana. RSU Zinātniskā konference: Tēzes (2014. gada 10.-11. aprīlis). Rīga: RSU, 2014, 335. lpp.

3. Skadins I., J Kroica J., Salma I., Reinis A., Sokolova M., Rostoka D., Berza N. Hidroksiapatīta-polipienskābes-ciprofloksacīna biomateriālu ar vidējo atvērto porainību 15\% antibakteriālās efektivitātes noteikšana, izmantojot Kirby-Bauer difūzijas metodi. RSU Zinātniskā konference: Tēzes (2014. gada 10.-11. aprīlis). Rīga: RSU, 2014, 334. lpp.

4. Skadins I., J Kroica J., Salma I., Reinis A., Sokolova M., Rostoka D., Berza N. Hidroksiapatīta-polipienskābes-ciprofloksacīna biomateriālu ar vidējo porainību 15\% antibakteriālā efektivitāte in vitro. RSU Zinātniskā konference: Tēzes (2014. gada 10.-11. aprīlis). Rīga: RSU, 2014, 336. lpp.

5. Skadins I., J Kroica J., Salma I., Reinis A., Sokolova M., Rostoka D., Berza N., Brakovska P., Jaunzeme A., Pētersons K., Veckalns I., Pudule S. Biomateriālu antibakteriālās efektivitātes noteikšanas metodes ietekme uz antibakteriālo ilgumu. RSU Zinātniskā konference: Tēzes (2015. gada 26.-27. marts). Rīga: RSU, 2015, 307. lpp

6. Skadins I., J Kroica J., Salma I., Reinis A., Sokolova M., Rostoka D., Berza N., Brakovska P., Jaunzeme A., Pētersons K., Veckalns I., Pudule S. Fiziologískās vides ietekme uz biomateriāliem ar biodegradējamu polipienskābes polimēru. RSU Zinātniskā konference: Tēzes (2015. gada 26.-27. marts). Rīga: RSU, 2015, 306. lpp. 


\section{IZMANTOTĀ LITERATŪRA}

1. Agarwal A., Singh K. P., Jain A. Medical significance and management of staphylococcal biofilm // FEMS Immunol Med Microbiol, 2010; 58(2): 147-160.

2. Ahmed R. M., Hannigan I. P., MacDougall H. G., Chan R. C., Halmagyi G. M. Gentamicin ototoxicity: a 23-year selected case series of 103 patients // Med J Aust, 2012; 196 (11): 701-704.

3. Ahola N., Männistö N., Veiranto M., Karp M., Rich J., Efimov A., et al. An in vitro study of composites of poly(L-lactide-co-e-caprolactone), $\beta$-tricalcium phosphate and ciprofloxacin intended for local treatment of osteomyelitis // Biomatter, 2013; 3(2): e23162.

4. Aires J. R., Köhler T., Nikaido H., Plésiat P. Involvement of an active efflux system in the natural resistance of Pseudomonas aeruginosa to Aminoglycosides // Antimicrob Agents Chemother, 1999; 43(11): 2624-2628.

5. Aldrete Sdel M., Magee M. J., Friedman-Moraco R. J., Chan A. W., Banks G. G., Burd E. M., Kraft C. S. Characteristics and antibiotic use associated with short-term risk of Clostridium difficile iInfection among hospitalized patients // Am J Clin Pathol, 2015; 143(6): 895-900.

6. Alexander W. S., Hilton D. J. The many roles of chemokines and chemokine receptors in inflammation // Annu Rev Immunol, 2004; 22: 503-529.

7. American Thoracic Society; Infectious Diseases Society of America. Guidelines for the management of adults with hospital-acquired, ventilator-associated, and healthcareassociated pneumonia // Am J Respir Crit Care Med, 2005 Feb 15; 171(4): 388-416.

8. Aminov R. I. A brief history of the antibiotic era: lessons learned and challenges for the future // Front Microbiol, 2010; 1: 134.

9. Aminov R. I. The role of antibiotics and antibiotic resistance in nature // Environ. Microbiol, 2009; 11: 2970-2988.

10. Ata-Ali J., Flichy-Fernández J. A., Alegre-Domingo T., Ata-Ali F., Palacio J., Peñarrocha-Diago M. Clinical, microbiological, and immunological aspects of healthy versus peri-implantitis tissue in full arch reconstruction patients: a prospective crosssectional study // BMC Oral Health, 2015; 15: 4.

11. Armentano I., Dottori M., Fortunati E., Mattioli S., Kenny J. M. Biodegradable polymer matrix nanocomposites for tissue engineering: a review // Polymer Degradation and Stability, 2010; 2126-2146.

12. Ball P. Quinolone generations: natural history or natural selection? // J Antimicrob Chemother, 2000; 46 Suppl T1: 17-24.

13. Banerjee I., Pangule R. C., Kane R. S. Antifouling coatings: recent developments in the design of surfaces that prevent fouling by proteins, bacteria, and marine organisms // Adv Mater, 2011; 23: 690-718.

14. Barken K. B., Pamp S. J., Yang L., Gjermansen M., Bertrand J. J., Klausen M., et al. Roles of type IV pili, flagellum-mediated motility and extracellular DNA in the formation of mature multicellular structures in Pseudomonas aeruginosa biofilms // Environ Microbiol, 2008; 10(9): 2331-2343.

15. Bauer A. W., Kirby W. M. M., Sherris J. C., Turck M. Antibiotic susceptibility testing by a standardized single disk method // Am J Clin Pathol, 1966; 36: 493-496.

16. Belcarz A., Ginalska G., Zalewska J., Rzeski W., Slósarczyk A., Kowalczuk D., et al. Covalent coating of hydroxyapatite by keratin stabilizes gentamicin release // J Biomed Mater Res B Appl Biomater, 2009; 89(1): 102-113. 
17. Biswal I., Arora B. S., Kasana D. Incidence of multidrug resistant Pseudomonas aeruginosa isolated from burn patients and environment of teaching institution // J Clin Diagn Res, 2014; 8(5): DC26-DC29.

18. Busscher H. J., van der Mei H. C., Subbiahdoss G., Jutte P. C., van den Dungen J. J., Zaat S. A., et al. Biomaterial-associated infection: locating the finish line in the race for the surface // Sci Transl Med, 2012; 4(153): 153rv10.

19. Büttner H., Mack D., Rohde H. Structural basis of Staphylococcus epidermidis biofilm formation: mechanisms and molecular interactions // Front Cell Infect Microbiol, 2015; 5(14): 1-15.

20. Campoccia D., Montanaro L., Speziale P., Arciola C. R. Antibiotic-loaded biomaterials and the risks for the spread of antibiotic resistance following their prophylactic and therapeutic clinical use // Biomaterials, 2010; 31(25): 6363-6377.

21. Campoli-Richards D. M., Monk J. P., Price A., Benfield P., Todd P. A., Ward A. Ciprofloxacin. A review of its antibacterial activity, pharmacokinetic properties and therapeutic use // Drugs, 1988 Apr; 35(4): 373-447.

22. Caron W. P., Mousa S. A. Prevention strategies for antimicrobial resistance: a systematic review of the literature // Infect Drug Resist, 2010; 3: 25-33.

23. Chai F., Hornez J. C., Blanchemain N., Neut C., Descamps M., Hildebrand H. F. Antibacterial activation of hydroxyapatite (HA) with controlled porosity by different antibiotics // Biomol Eng, 2007 Nov; 24(5): 510-514.

24. Chain E., Florey H. W., Gardner A. D., Heatley N. G., Jennings M. A., Orr-Ewing J., et al. Penicillin as a chemotherapeutic agent // The Lancet, 1940; 236(6104): 226-228.

25. Chang H. I., Lau Y. C., Yan C., Coombes A. G. Controlled release of an antibiotic, gentamicin sulphate, from gravity spun polycaprolactone fibers // J Biomed Mater Res A, 2008; 84(1): 230-237.

26. Chang Y., Tai C. L., Hsieh P. H., Ueng S. W. Gentamicin in bone cement: a potentially more effective prophylactic measure of infectionin joint arthroplasty // Bone Joint Res, 2013; 2(10): 220-226.

27. Charo I. F., Ransohoff R. M. The many roles of chemokines and chemokine receptors in inflammation // N Engl J Med, 2006; 354(6): 610-621.

28. Chatzistavrou X., Velamakanni S., DiRenzo K., Lefkelidou A., Fenno J. C., Kasuga T., et al. Designing dental composites with bioactive and bactericidal properties // Mater Sci Eng C Mater Biol Appl, 2015; 52: 267-272.

29. Chen Q., Thouas G. A. Metallic implant biomaterials // Materials Science and Engineering: R: Reports, 2015; 87: 1-57.

30. Chew B. H., Lange D. Ureteral stent symptoms and associated infections: a biomaterials perspective // Nature Reviews Urology, 2009; 6: 440-448.

31. Chikwendu C. I., Amadi E. S., Obi R. K. Revalence and antimicrobial resistance in Pseudomonas aeruginosa and Klebsiella pneumoniae isolates from non-clinical urine samples // New York Science Journal, 2010; 3(11): 194-200.

32. Chopra I., Roberts M. Tetracycline antibiotics: mode of action, applications, molecular biology, and epidemiology of bacterial resistance // Microbiol Mol Biol Rev, 2001; 65(2): 232-260.

33. Choy M. H., Stapleton F., Willcox M. D., Zhu H. Comparison of virulence factors in Pseudomonas aeruginosa strains isolated from contact lens- and non-contact lens-related keratitis // J Med Microbiol, 2008; 57(Pt 12): 1539-1546.

34. Clardy J., Fischbach M., Currie C. The natural history of antibiotics // Current Biology, 2009; 19: 437-441. 
35. Cogen A. L., Nizet V., Gallo R. L. Skin microbiota: a source of disease or defence? // Br J Dermatol, 2008; 158(3): 442-455.

36. Coraça-Huber D. C., Hausdorfer J., Fille M., Nogler M. Effect of storage temperature on gentamicin release from antibiotic-coated bone chips // Cell Tissue Bank, 2013; 14(3): 395-400.

37. Costa Almeida C. E., Reis L., Carvalho L., Costa Almeida C. M. Collagen implant with gentamicin sulphate reduces surgical site infection in vascular surgery: a prospective cohort study // Int J Surg, 2014; 12(10): 1100-1104.

38. Costa F., Carvalho I. F., Montelaro R. C., Gomes P., Martins M. C. Covalent immobilization of antimicrobial peptides (AMPs) onto biomaterial surfaces // Acta Biomater, 2011;7(4): 1431-1440.

39. Cunha B. A. Antibiotic side effects // Med Clin North Am, 2001; 85(1): 149-185.

40. Dalhoff A. Global fluoroquinolone resistance epidemiology and implictions for clinical use // Interdisciplinary Perspectives on Infectious Diseases, 2012; 2012, Article ID 976273.

41. Dankert J., Hogt A. H., Feijen J., Biomedical polymers: Bacterial adhesion, colonization, and infection // CRC Crit Rev Biocompat, 1986; 2: 219-301.

42. Darouiche R. O. Device-associated infections: a macroproblem that starts with microadherence // Clin Infect Dis, 2001; 33(9): 1567-1572.

43. Das M., Badley A. D., Cockerill F. R., Steckelberg J. M., Wilson W. R. Infective endocarditis caused by HACEK microorganisms // Annu Rev Med, 1997; 48: 25-33.

44. Davies J. C. Pseudomonas aeruginosa in cystic fibrosis: pathogenesis and persistence // Paediatr Respir Rev, 2002; 3(2): 128-134.

45. Desai S. N., Kikani K. M., Mehta S. J. Microbilogical surveillance of operation theaters $\&$ intensive care units of teaching hospital in Surendranagar, Gujarat // Gujarat Medical Journal, 2012; 67(2): 95-97.

46. Diekema D. J., Pfaller M. A., Schmitz F. J., Smayevsky J., Bell J., Jones R. N., et al. Survey of infections due to Staphylococcus species: frequency of occurrence and antimicrobial susceptibility of isolates collected in the United States, Canada, Latin America, Europe, and the Western Pacific region for the SENTRY Antimicrobial Surveillance Program, 1997-1999 // Clin Infect Dis, 2001; 32 Suppl 2: S114-132.

47. DiZerega G. S., Traylor M. M., Alphonso L. S., Falcone S. J. Use of temporary implantable biomaterials to reduce leg pain and back pain in patients with sciatica and lumbar disc herniation // Materials, 2010; 3(5): 3331-3368.

48. Duarte P. M., de Mendonça A. C., Máximo M. B., Santos V. R., Bastos M. F., Nociti Júnior F. H. Differential cytokine expressions affect the severity of peri-implant disease // Clin Oral Implants Res, 2009; 20(5): 514-520.

49. Eisenhart A. E., Disso N. M. Thermostability determination of antibiotics at high temperatures by liquid Chromatography-Mass Spectrometry // Proceedings of the National Conference on Undergraduate Research (NCUR), Weber State University, 2012.

50. Espat N. J., Copeland E. M., Moldawer L. L. Tumor necrosis factor and cachexia: a current perspective // Surg Oncol, 1994; 3(5): 255-262.

51. Estahbanati H. K., Kashani P. P., Ghanaatpisheh F. Frequency of Pseudomonas aeruginosa serotypes in burn wound infections and their resistance to antibiotics // Burns, 2002; 28(4): 340-348. 
52. Fantin B., Duval X., Massias L., Alavoine L., Chau F., Retout S., et al. Ciprofloxacin dosage and emergence of resistance in human commensal bacteria // J Infect Dis, 2009; 1; 200(3): 390-398.

53. Feng K., Sun H., Bradley M. A., Dupler E. J., Giannobile W. V., Ma P. X. Novel antibacterial nanofibrous PLLA scaffolds // J Control Release, 2010; 146(3): 363-369.

54. Fey P. D., Olson M. E. Current concepts in biofilm formation of Staphylococcus epidermidis // Future Microbiol, 2010; 5(6): 917-933.

55. Fleming A. On the antibacterial action of cultures of a penicillium, with special reference to their use in the isolation of B. influenzae // British Journal of Experimental Pathology, 1929; 10 (31): 226-236.

56. Franz S., Rammelt S., Scharnweber D., Simon J. C. Immune responses to implants a review of the implications for the design of immunomodulatory biomaterials // Biomaterials, 2011; 32(28): 6692-6709.

57. Gallo R. L., Nakatsuji T. Microbial symbiosis with the Innate Immune Defense System of the skin // J Invest Dermatol, 2011; 131(10): 1974-1980.

58. Garhwal R., Shady S. F., Ellis E. J., Ellis J. Y., Leahy C. D., McCarthy S. P., et al. Sustained ocular delivery of Ciprofloxacin using nanospheres and conventional contact lens materials // Invest Ophthalmol Vis Sci, 2012; 53(3): 1341-1352.

59. Goldmann D. A., Pier G. B. Pathogenesis of infections related to intravascular catheterization // Clin Microbiol Rev, 1993; 6(2): 176-192.

60. Gollwitzer H., Dombrowski Y., Prodinger P. M., Peric M., Summer B., Hapfelmeier A., et al. Antimicrobial peptides and proinflammatory cytokines in periprosthetic joint infection // J Bone Joint Surg Am, 2013; 95(7): 644-651.

61. Gomes M. E., Reis R. L. Biodegradable polymers and composites in biomedical applications: from catgut to tissue engineering. Part 1: Available systems and their properties // International Materials Reviews, 2004; 49(5): 261-273.

62. Gottenbos B., Busscher H. J., Van Der Mei H. C., Nieuwenhuis P. Pathogenesis and prevention of biomaterial centered infections // J Mater Sci Mater Med, 2002; 13(8): 717-722.

63. Gould F. K., Denning D. W., Elliott T.S.J., Foweraker J., Perry D. J., Prendergast B. D., et al. Guidelines for the diagnosis and antibiotic treatment of endocarditis in adults: a report of the Working Party of the British Society for Antimicrobial Chemotherapy // J Antimicrob Chemother, 2012; 67: 269-289.

64. Graham J. C., Gould F. K. Role of aminoglycosides in the treatment of bacterial endocarditis // J Antimicrob Chemother, 2002; 49 (3): 437-444.

65. Greco G., Shi W., Michler R. E., Meltzer D. O., Ailawadi G., Hohmann S. F., Thourani V. H., Argenziano M., Alexander J. H., Sankovic K., Gupta L., Blackstone E. H., Acker M. A., Russo M. J., Lee A., Burks S. G., Gelijns A. C., Bagiella E., Moskowitz A. J., Gardner T. J. Costs associated with health care-associated infections in cardiac surgery // J Am Coll Cardiol, 2015; 65(1): 15-23.

66. Green K. D., Chen W, Garneau-Tsodikova S. Effects of altering aminoglycoside structures on bacterial resistance enzyme activities // Antimicrob Agents Chemother, 2011; 55(7): 3207-3213.

67. Gul M., Yasim A., Aral M. The levels of cytokines in rats following the use of prophylactic agents in vascular graft infection // Bratisl Lek Listy, 2010; 111(6): 316-320.

68. Gunatillake P. A., Adhikari R. Biodegradable synthetic polymers for tissue engineering // Eur Cell Mater, 2003; 20(5): 1-16. 
69. Haenle M., Skripitz C., Mittelmeier W., Skripitz R. Economic impact of infected total knee arthroplasty // Scientific World Journal, 2012; 2012: 196515.

70. Harmsen M., Yang L., Pamp S. J., Tolker-Nielsen T. An update on Pseudomonas aeruginosa biofilm formation, tolerance, and dispersal // FEMS Immunol Med Microbiol, 2010; 59(3): 253-268.

71. Heydenrijk K., Meijer H. J., van der Reijden W. A., Raghoebar G. M., Vissink A., Stegenga B. Microbiota around root-form endosseous implants: a review of the literature // Int J Oral Maxillofac Implants, 2002; 17(6): 829-838.

72. Higgins C. E., Kastner R. E. Nebramycin, a new broad-spectrum antibiotic complex. Description of Streptomyces tenebrarius // Antimicrob Agents Chemother 1967; 7: 324-331.

73. Höland W., Schweiger M., Watzke R., Peschke A., Kappert H. Ceramics as biomaterials for dental restoration // Expert Rev Med Devices. 2008; 5(6): 729-45.

74. Hooper D. C., Wolfson J. S., Ng E. Y., Swartz M. N. Mechanisms of action of and resistance to ciprofloxacin // Am J Med, 1987; 27;82(4A): 12-20.

75. Hooton T. M., Bradley S. F., Cardenas D. D., Colgan R., Geerlings S. E., Rice J. C., et al. Diagnosis, prevention and treatment of catheter-associated urinary tract infection in adults // Clin Infect Dis, 2010; 50(5): 625-563.

76. Huebsch N., Mooney D. J. Inspiration and application in the evolution of biomaterials // Nature, 2009; 462(7272): 426-432.

77. Huth M. E., Ricci A. J., Cheng A. G. Mechanisms of aminoglycoside ototoxicity and targets of hair cell protection // Int J Otolaryngol, 2011; Article ID 937861, 19 pages.

78. Isoherranen N., Lavy E., Soback S. Pharmacokinetics of Gentamicin C1, C1a, and C2 in Beagles after a Single Intravenous Dose // Antimicrob Agents Chemother, 2000; 44(6): 1443-1447.

79. Iwakura T., Lee S. Y., Niikura T., Miwa M., Sakai Y., Nishida K. et al. Gentamycinimpregnated calcium phosphate cement for calcaneal osteomyelitis: a case report // J Orthop Surg (Hong Kong). 2014; 22(3): 437-439.

80. Jacobsen S. M., Stickler D. J., Mobley H. L. T., Shirtliff M. E. Complicated CatheterAssociated Urinary Tract Infections Due to Escherichia coli and Proteus mirabilis // Microbiol Rev, 2008; (1): 26-59.

81. Jacoby G. A. Mechanisms of Resistance to Quinolones // Clin Infect Dis. 2005; 15(41): Suppl 2: S120-S126.

82. Johnson J. R., Brian Johnston B., Kuskowski M.A. In Vitro Comparison of Nitrofurazone- and Silver Alloy-Coated Foley Catheters for Contact-Dependent and Diffusible Inhibition of Urinary Tract Infection-Associated Microorganisms // Antimicrob Agents Chemother, 2012; 56(9): 4969-4972.

83. Kankilic B., Bayramli E., Kilic E., Dağdeviren S., Korkusuz F. Vancomycin Containing PLLA/ $\beta$-TCP Controls MRSA In Vitro // Clin Orthop Relat Res, 2011; 469(11): 32223228.

84. Kankilic B., Bilgic E., Korkusuz P., Korkusuz F. Vancomycin containing PLLA/ $\beta$-TCP controls experimental osteomyelitis in vivo // J Orthop Surg Res, 2014; 19; 9:114.

85. Kim G. K. The Risk of Fluoroquinolone-induced Tendinopathy and Tendon Rupture // J Clin Aesthet Dermatol. 2010 Apr; 3(4): 49-54.

86. Kim H. W., Knowles J. C., Kim H. E. Hydroxyapatite porous scaffold engineered with biological polymer hybrid coating for antibiotic Vancomycin release // J Mater Sci Mater Med, 2005; 16(3): 189-195. 
87. Kim H. W., Knowles J. C., Kim H. E. Development of Hydroxyapatite Bone Scaffold for Controlled Drug Release via Poly( $\varepsilon$-caprolactone) and Hydroxyapatite Hybrid Coatings // J Biomed Mater Res B Appl Biomater, 2004; 70(2): 240-249.

88. King D.E., Malone R., Lilley S. New Classification and Update on the Quinolone Antibiotics. Am Fam Physician. 2000; 61(9): 2741-2748.

89. Kloos W., Schleifer K. H. In:// Bergey's Manual of Systematic Bacteriology. Baltimore: Williams \& Wilkins, 1986.

90. Kohane D. S., Langer R. Polymeric biomaterials in tissue engineering // Pediatric Research, 2008; 63: 487-491.

91. Kohanski M. A., Dwyer D. J., Collins J. J. How antibiotics kill bacteria: from targets to networks // Nat Rev Microbiol, 2010; 8(6): 423-435.

92. Kundu B., Soundrapandian C., Nandi S. K., Mukherjee P., Dandapat N., Roy S. Development of new localized drug delivery system based on ceftriaxone-sulbactam composite drug impregnated porous hydroxyapatite: a systematic approach for in vitro and in vivo animal trial // Pharm Res, 2010; 27(8): 1659-1676.

93. Lambert T. Antibiotics that affect the ribosome // Rev Sci Tech, 2012; 31(1): 57-64.

94. Landersdorfer C. B., Kirkpatrick C. M. J., Kinzig M., Bulitta J. B., Holzgrabe U., Jaehde U., et al. Competitive inhibition of renal tubular secretion of ciprofloxacin and metabolite by probenecid // Br J Clin Pharmacol, 2010; 69(2): 167-178.

95. Laupland K. B., Lee H., Gregson D. B., Manns B. J. Cost of intensive care unitacquired bloodstream infections // J Hosp Infect, 2006; 63(2): 124-132.

96. Laurent T., Kacem I., Blanchemain N., Cazaux F., Neut C., Hildebrand H. F., et al. Cyclodextrin and maltodextrin finishing of a polypropylene abdominal wall implant for the prolonged delivery of ciprofloxacin // Acta Biomater, 2011; 7(8): 3141-3149.

97. Lazebnik N., Noy S., Lazebnik R., Hezroni Y., Amoday I., Aviram A. Gentamicin serum half-life: a comparison between pregnant and non-pregnant women // Postgrad Med J, 1985; 61(721): 979-981.

98. LeBel M. Ciprofloxacin: chemistry, mechanism of action, resistance, antimicrobial spectrum, pharmacokinetics, clinical trials, and adverse reactions // Pharmacotherapy, 1988; 8(1): 3-33.

99. Lee H. S., Parka S. H., Lee J. H., Jeonga B. Y., Ahn S. K., Choi Y. M., et al. Antimicrobial and biodegradable PLGA medical sutures with natural grapefruit seed extracts // Materials Letters, 2013; 95: 40-43.

100. Leibovici L., Vidal L., Paul M. Aminoglycoside drugs in clinical practice: an evidencebased approach // J Antimicrob Chemother, 2009; 63(2): 246-251.

101. Leprêtre S., Chai F., Hornez J. C., Vermet G., Neut C., Descamps M., et al. Prolonged local antibiotics delivery from hydroxyapatite functionalised with cyclodextrin polymers // Biomaterials, 2009; 30(30): 6086-6093.

102. Lesher G. Y., Froelich E. J., Gruett M. D., Bailey J. H., Brundage R. P. 1, 8naphthyridine derivatives: a new class of chemotherapeutic agents // J Med Pharm Chem, 1962; 91: 1063-1065.

103. Li Z., Kong W., Li X., Xu C., He Y., Gao J. Antibiotic-containing biodegradable bead clusters with porous PLGA coating as controllable drug-releasing bone fillers // J Biomater Sci Polym Ed, 2011; 22(13): 1713-1731.

104. Lian X., Liuc H., Wanga X., Xua S., Cuia F., Bai X. Antibacterial and biocompatible properties of vancomycin-loaded nano-hydroxyapatite/collagen/poly (lactic acid) bone substitute // Progress in Natural Science: Materials International, 2013; 23(6): 549-556. 
105. Libby P. Inflammatory mechanisms: the molecular basis of inflammation and disease // Nutr Rev, 2007; 65(12 Pt 2): S140-146.

106. Ligon B. L. Penicillin: its discovery and early development // Semin Pediatr Infect Dis, 2004; 15(1): 52-57.

107. Lister P. D., Wolter D. J., Hanson N. D. Antibacterial-resistant Pseudomonas aeruginosa: clinical impact and complex regulation of chromosomally encoded resistance mechanisms // Clin Microbiol Rev, 2009; 22(4): 582-610.

108. Loca D., Locs J., Salma K., Gulbis J., Salma I., Berzina-Cimdina L. Porous Hydroxyapatite bioceramic scaffolds for drug delivery and bone regeneration // Mater. Sci. Eng., 2011; 18: 192019.

109. Loca D., Sokolova M., Locs J., Smirnova A., Irbe A. Calcium phosphate bone cements for local vancomycin delivery // Materials Science and Engineering: C, 2015; 49: $106-113$.

110. Locs J., Zalite V., Berzina-Cimdina L., Sokolova M. Ammonium hydrogen carbonate provided viscous slurry foaming - a novel technology for the preparation of porous ceramics // J Eur Ceram Soc, 2013; 33: 3437-3443.

111. Low D. E. Fluoroquinolone-resistant pneumococci: maybe resistance isn't futile? // Clin Infect Dis, 2005; 40(2): 236-238.

112. Lutz J. K., Lee J. Prevalence and antimicrobial-resistance of Pseudomonas aeruginosa in swimming pools and hot tubs // Int J Environ Res Public Health, 2011; 8(2): 554-564.

113. Ma L. Y., Jackson K., Landry R. M., Parsek M. R., Wozniak D. J. Analysis of Pseudomonas aeruginosa conditional Psl variants reveals roles for the Psl polysaccharide in adhesion and maintaining biofilm structure postattachment // J Bacteriol, 2006; 188: 8213-8221.

114. Ma Z., Gao C., Gong Y., Shen J. Cartilage tissue engineering PLLA scaffold with surface immobilized collagen and basic fibroblast growth factor // Biomaterials, 2005; 26(11): 1253-1259.

115. MacGregor R. R., Graziani A. L., Esterhai J. L. Oral ciprofloxacin for osteomyelitis // Orthopedics, 1990; 13(1): 55-60.

116. Mack D., Becker P., Chatterjee I., Dobinsky S., Knobloch J. K., Peters G., et al. Mechanisms of biofilm formation in Staphylococcus epidermidis and Staphylococcus aureus: functional molecules, regulatory circuits, and adaptive responses // Int J Med Microbiol, 2004; 294(2-3): 203-212.

117. Mandal J., Srinivas Acharya N., Buddhapriya D., Chandra Parija S. Antibiotic resistance pattern among common bacterial uropathogens with a special reference to ciprofloxacin resistant Escherichia coli // Indian J Med Res, 2012; 136: 842-849.

118. Mann H. B., Whitney D. R. On a Test of whether one of two random variables is stochastically larger than the other // Ann Math Statist, 1947; 18(1): 50-60.

119. McLaren J. S., White L. J., Cox H. C., Ashraf W., Rahman C.V., Blunn G. W., et al. A biodegradable antibiotic-impregnated scaffold to prevent osteomyelitis in a contaminated in vivo bone defect model // Eur Cell Mater, 2014; 27: 332-349.

120. Micek S. T., Lloyd A. E., Ritchie D. J., Reichley R. M., Fraser V. J., Kollef M. H. Pseudomonas aeruginosa bloodstream infection: importance of appropriate initial antimicrobial treatment // Antimicrob Agents Chemother, 2005; 49(4): 1306-1311.

121. Mingeot-Leclercq M. P., Tulkens P. M. Aminoglycosides: nephrotoxicity // Antimicrob Agents Chemother, 1999; 43(5): 1003-1012. 
122. Mingeot-Leclercq M. P., Glupczynski Y., Tulkens P. M. Aminoglycosides: activity and resistance // Antimicrob Agents Chemother, 1999; 43(4): 727-737.

123. Misawa Y., Muraoka A., Ohki S., Aizawa K., Kawahito K., Saito T., et al. Fifteen-year experience with the Bicarbon heart valve prosthesis in a single center // J Cardiothorac Surg, 2015; 10: 89.

124. Mondrinos M.J., Dembzynski R., Lu L., Byrapogu V.K.C., Wootton D. M., Lelkes P. I., et al. Porogen-based solid freeform fabrication of polycaprolactone-calcium phosphate scaffolds for tissue engineering // Biomaterials, 2006; 27: 4399-4408.

125. Moore K. W., de Waal Malefyt R., Coffman R. L., O'Garra A. Interleukin-10 and the interleukin-10 receptor // Annu Rev Immunol, 2001; 19: 683-765.

126. Moore R. D., Lietman P. S., Smith C. R. Clinical response to aminoglycoside therapy: importance of the ratio of peak concentration to minimal inhibitory concentration // J. Infect. Dis, 1987; 155: 93-99.

127. Morais M. J., Papadimitrakopoulos F., Burgess D. J. Biomaterials/tissue interactions: possible solutions to overcome foreign body response // AAPS J, 2010; 12(2): 188-196.

128. Murray J., Barbara J., Dunkley S., Lopez A., Van Ostade X., Condliffe I., et al. Regulation of Neutrophil apoptosis by Tumor Necrosis Factor-Alpha: requirements for TNF-R55 and TNF-R75 for induction of apoptosis in vitro // Blood, 1997; 90(7): 2772-2783.

129. Mylonakis E., Ryan E. T., Calderwood S. B. Clostridium difficile-associated diarrhea: a review // Arch Intern Med, 2001; 161(4): 525-533.

130. Nabera K. G., Buschb W., Focht J. Ciprofloxacin in the treatment of chronic bacterial prostatitis: a prospective, non-comparative multicentre clinical trial with long-term follow-up // Int J Antimicrob Agents, 2000; 14(2): 143-149.

131. Nair L. S., Laurencin C. T. Biodegradable polymers as biomaterials // Prog Polym Sci, 2007; 32: 762-798.

132. Navarro M., Michiardi A., Castano O., Planell J. A. Biomaterials in orthopaedics // J R Soc Interface, 2008; 5: 1137-1158.

133. Naveed S., Waheed N., Nazeer S., Qamar F. Degradation study of gentamicin by UV spectroscopy // American Journal of Chemistry and Applications, 2014; 1(4): 36-39.

134. Nicolle L. E. Catheter associated urinary tract infections // Antimicrobial Resistance and Infection Control, 2014; 3: 23.

135. Oliphant C. M., Green G. M. Quinolones: a comprehensive review // Am Fam Physician, 2002; 65(3): 455-464.

136. Otto M. Staphylococcus epidermidis - the "accidental" pathogen // Nat Rev Microbiol, 2009; 7(8): 555-567.

137. Parwe S. P., Chaudhari P. N., Mohite K. K., Selukar B. S., Nande S. S., Garnaik B. Synthesis of ciprofloxacin-conjugated poly (L-lactic acid) polymer for nanofiber fabrication and antibacterial evaluation // Int J Nanomedicine, 2014; 9: 1463-1477.

138. Patel N. R., Gohil P. P. A review on biomaterials: scope, applications \& human anatomy significance // International Journal of Emerging Technology and Advanced Engineering, 2012; 2(4): 91-101.

139. Payen S., Serreau R., Munck A., Aujard Y., Aigrain Y., Bressolle F., et al. Population pharmacokinetics of Ciprofloxacin in pediatric and adolescent patients with acute infections // Antimicrob Agents Chemother, 2003; 47(10): 3170-3178.

140. Peel T. N., Cheng A. C., Buising K. L., Choong P. F. Microbiological aetiology, epidemiology, and clinical profile of prosthetic joint infections: are current antibiotic 
prophylaxis guidelines effective? // Antimicrob Agents Chemother, 2012; 56(5): 23862391.

141. Pittet D., Tarara D., Wenzel R. P. Nosocomial bloodstream infection in critically ill patients: excess length of stay, extra costs, and attributable mortality // JAMA, 1994; 271: 1598-1601.

142. Poirel L., Rodriguez-Martinez J. M., Mammeri H., Liard A., Nordmann P. Origin of plasmid-mediated quinolone resistance determinant QnrA // Antimicrob Agents Chemother, 2005; 49: 3523-3525.

143. Pollack, M. Pseudomonas aeruginosa // G. L. Mandell, R. Dolan, J. E. Bennett (ed.) Principles and practices of infectious diseases. New York, NY: Churchill Livingstone, 1995, p. 1820-2003.

144. Poole K. Aminoglycoside resistance in Pseudomonas aeruginosa // Antimicrob. Agents Chemother, February 2005; 49(2): 479-487.

145. Pritchard E. M., Valentin T., Panilaitis B., Omenetto F., Kaplan D. L. Antibioticreleasing silk biomaterials for infection prevention and treatment // Adv Funct Mater, 2013; 23(7): 854-861.

146. Pulido L., Ghanem E., Joshi A., Purtill J. J., Parvizi J. Periprosthetic joint infection: the incidence, timing, and predisposing factors // Clin Orthop Relat Res, 2008; 466(7): 1710-1715.

147. Radek K., Gallo R. Antimicrobial peptides: natural effectors of the innate immune system // Seminars in Immunopathology, 2007; 29(1): 27-24.

148. Ranjan K. P., Ranjan N., Bansal S. K., Arora D. R. Prevalence of Pseudomonas aeruginosa in post-operative wound infection in a referral hospital in Haryana, India // J Lab Physicians, 2010; 2(2): 74-77.

149. Rasamiravaka T., Labtani Q, Duez P., El Jaziri M. The formation of biofilms by Pseudomonas aeruginosa: a review of the natural and synthetic compounds interfering with control mechanisms // BioMed Research International, 2015; 2015, Article ID 759348, 17 pages.

150. Reinis A., Pilmane M., Stunda A., Vētra J., Kroiča J., Rostoka D., et al. An in vitro and in vivo study on the intensity of adhesion and colonization by Staphylococcus epidermidis and Pseudomonas aeruginosa on originally synthesized biomaterials with different chemical composition and modified surfaces and their effect on expression of TNF- $\alpha, \beta$-defensin-2 and IL-10 in tissues // Medicina (Kaunas), 2011; 47(10): 560-565.

151. Ribeiro M., Monteiro F. J., Ferraz M. P. Infection of orthopedic implants with emphasis on bacterial adhesion process and techniques used in studying bacterial-material interactions // Biomatter, 2012; 2(4): 176-194.

152. Rogers K. L., Fey P. D., Rupp M. E. Coagulase-negative staphylococcal infections // Infect Dis Clin North Am, 2009; 23(1): 73-98.

153. Rousset F., Garcia E., Defrance T., Péronne C., Vezzio N., Hsu D. H., et al. Interleukin 10 is a potent growth and differentiation factor for activated human B lymphocytes // Proc Natl Acad Sci, 1992; 89(5): 1890-1893.

154. Ryder C., Byrd M., Wozniak D. J. Role of polysaccharides in Pseudomonas aeruginosa biofilm development // Curr Opin Microbiol, 2007; 10(6): 644-648.

155. Sáenz A., Rivera-Muñoz E., Brostow W. Castañ V. M. Ceramic biomaterials: an introductory overview // Journal of Materials Education, 1999; 21(56): 297-306.

156. Sauer K., Camper A. K., Ehrlich G. H., Costerton J. W., Davies D. G. Pseudomonas aeruginosa displays multiple phenotypes during development as a biofilm // J Bacteriol, 2002; 184(4): 1140-1154. 
157. Schnieders J., Gbureck U., Thull R., Kissel T. Controlled release of gentamicin from calcium phosphate-poly(lactic acid-co-glycolic acid) composite bone cement // Biomaterials, 2006; 27(23): 4239-4249.

158. Schnieders J., Gbureck U., Vorndran E., Schossig M., Kissel T. The effect of porosity on drug release kinetics from vancomycin microsphere/calcium phosphate cement composites // J Biomed Mater Res B Appl Biomater, 2011; 99(2): 391-398.

159. Schröder J. M., Harder J. Antimicrobial skin peptides and proteins // Cellular and Molecular Life Sciences, 2006; 63(4): 469-486.

160. Schröder J. M., Harder J. Human beta-defensin-2 // Int J Biochem Cell Biol, 1999; 31(6): 645-651.

161. Schuttea R. J., Xiea L., Klitzmana B., Reichert W. M. In vivo cytokine-associated responses to biomaterials // Biomaterials, 2009; 30(2): 160-168.

162. Seala B. L., Oterob T. C., Panitch A. Polymeric biomaterials for tissue and organ regeneration // Materials Science and Engineering: R: Reports, 2001; 34(4): 147-230.

163. Seng P., Bayle S., Alliez A., Romain F., Casanova D., Stein A. The microbial epidemiology of breast implant infections in a regional referral centre for plastic and reconstructive surgery in the south of France // Int J Infect Dis, 2015; 35: 62-66.

164. Shikinami Y., Okuno M. Bioresorbable devices made of forged composites of Hydroxyapatite (HA) particles and Polyl-lactide (PLLA). Part II: Practical properties of miniscrews and miniplates // Biomaterials, 2001; 22(23): 3197-3211.

165. Smyth A. R., Bhatt J. Once-daily versus multiple-daily dosing with intravenous aminoglycosides for cystic fibrosis // Cochrane Database Syst Rev, 2010; 20(1): CD002009.

166. Sokolova M., Putniņš A., Kreicbergs I., Ločs J. Scale-up of wet precipitation calcium phosphate synthesis // Key Engineering Materials, 2014; 604: 216-219.

167. Solomkin J. S., Mazuski J. E., Bradley J. S., Rodvold K. A., Goldstein E. J., Baron E. J., et al. Diagnosis and management of complicated intra-abdominal infection in adults and children: guidelines by the Surgical Infection Society and the Infectious Diseases Society of America // Clin. Infect. Dis., 2010; 50 (2): 133-164.

168. Soothill G., Hu Y., Coates A. Can we prevent antimicrobial resistance by using antimicrobials better? // Crit Rev Ther Drug Carrier Syst, 2015; 32(1): 1-59.

169. Stanley N. R., Lazazzera B. A. Environmental signals and regulatory pathways that influence biofilm formation // Mol Microbiol, 2004; 52(4): 917-924.

170. Stewart P. S., Costerton J. W. Antibiotic resistance of bacteria in biofilms // Lancet, 2001; 358: 135-138.

171. Suming L., Vert M. Biodegradation of aliphatic polyesters // Springer, Netherlands, 2002, 71-131.

172. Sutter V. L., Kwok Y. Y., Bulkacz J. Comparative activity of ciprofloxacin against anaerobic bacteria // Antimicrob Agents Chemother, 1985; 27(3): 427-428.

173. Tam V. H., Kabbara S., Vo G., Schilling A. N., Coyle E. A. Comparative pharmacodynamics of Gentamicin against Staphylococcus aureus and Pseudomonas aeruginosa // Antimicrob Agents Chemother,2006; 50(8): 2626-2631.

174. Tamai H., Igaki K., Kyo E., Kosuga K., Kawashima A., Matsui S., et al. Initial and 6month results of biodegradable poly-l-lactic acid coronary stents in humans // Circulation, 2000; 102(4): 399-404.

175. The European Committee on Antimicrobial Susceptibility Testing - EUCAST. Disk Diffusion Method for antimicrobial susceptibility testing, Manual ver. 5.0 // 
http://www.eucast.org/fileadmin/src/media/PDFs/EUCAST_files/Disk_test_documents/ Manual_v_5.0_EUCAST_Disk_Test.pdf (sk. 04.02.2015.).

176. Tischer T. S., Hollstein A., Voss W., Wendig I., Lauschke J., Schneider R., et al. A historical perspective of pacemaker infections: 40-years single-centre experience // Europace, 2014; 16(2): 235-240.

177. Tokiwa Y., Calabia B. P., Ugwu C. U., Aiba S. Biodegradability of plastics // Int J Mol Sci, 2009; 10(9): 3722-3742.

178. Tracey K. J., Cerami A. Tumor necrosis factor: a pleiotropic cytokine and therapeutic target // Annu Rev Med, 1994; 45: 491-503.

179. Trampuz A., Zimmerli W. Prosthetic joint infections: update in diagnosis and treatment // Swiss Med Wkly, 2005; 135(17-18): 243-251.

180. Turnidge J. Pharmacokinetics and pharmacodynamics of fluoroquinolones // Drugs, 1999; 58: 29-36.

181. Ulery B. D., Nair L. S., Laurencin C. T. Biomedical applications of biodegradable polymers // J Polym Sci B Polym Phys, 2011; 49(12): 832-864.

182. Umezawa H., Ueda M., Maeda K., Yagishita K., Kondo S., Okami Y., et al. Production and isolation of a new antibiotic: kanamycin // J Antibiot 1957; 10(5): 181-188.

183. van de Belt H., Neut D., Schenk W., van Horn J. R., van der Mei H. C., Busscher H. J. Infection of orthopedic implants and the use of antibiotic-loaded bone cements. A review // Acta Orthop Scand, 2001; 72(6): 557-571.

184. Van Delden C., Iglewski B. H. Cell-to-cell signaling and Pseudomonas aeruginosa infections // Emerg Infect Dis, 1998; 4(4): 551-560.

185. Vance-Bryan K., Guay D. R. P., Rotschafer J. C. Clinical pharmacokinetics of Ciprofloxacin // Clinical Pharmacokinetics, 1990; 19(6): 434-461.

186. Vanhems P., Baratin D., Voirin N., Savey A., Caillat-Vallet E., Metzger M. H., et al. Reduction of urinary tract infections acquired in an intensive care unit during a 10-year surveillance program // Eur J Epidemiol, 2008; 23(9): 641-645.

187. Venkatesh M. P., Placencia F., Weisman L. E. Coagulase-negative staphylococcal infections in the neonate and child: an update // Semin Pediatr Infect Dis, 2006; 17(3): $120-127$.

188. Vinh D. C., Embil J. M. Device-related infections: a review // J Long Term Eff Med Implants, 2005; 15(5): 467-488.

189. von Eiff C., Jansen B., Kohnen W., Becker K. Infections associated with medical devices: pathogenesis, management and prophylaxis // Drugs, 2005; 65(2): 179-214.

190. Vroman I., Tighzert L. Biodegradable polymers // Materials, 2009; 2: 307-344.

191. Wajant H., Pfizenmaier K., Scheurich P. Tumor necrosis factor signaling // Cell Death Differ, 2003; 10(1): 45-65.

192. Waksman S. A, Bugie E., Schatz A. Isolation of anti-biotic substances from soil microorganisms with special reference to streptothricin and streptomycin // Proc Staff Meet Mayo Clin, 1944; 19: 537.

193. Waksman S. A., Lechevalier H. A. Neomycin, a new antibiotic active against Streptomycin-Resistant Bacteria, including tuberculosis organisms // Science, 1949; 109(2830): 305-307.

194. Waksman, S.A., Tishler, M. The chemical nature of actinomycin, an anti-microbial substance produced by Actinomyces antibioticus // J. Biol. Chem, 1942; 142: 519-528.

195. Wang A., Athan E., Pappas P. A., Fowler V. G. Jr., Olaison L., Paré C., et al. Contemporary clinical profile and outcome of prosthetic valve endocarditis // JAMA, 2007; 297(12): 1354-1361. 
196. Webb J. C., Gbejuade H., Lovering A., Spencer R. Characterisation of in vivo release of gentamicin from polymethyl methacrylate cement using a novel method // Int Orthop, 2013; 37(10): 2031-2036.

197. Wei B. P. C., Robins-Browne R. M., Shepherd R. K., Azzopardi K., Clark G. M., O'Leary S. J. Protective effects of local administration of ciprofloxacin on the risk of pneumococcal meningitis following cochlear implantation // Laryngoscope, 2006; 116(12): 2138-2144.

198. Wei Q., Ma L. Z. Biofilm matrix and its regulation in Pseudomonas aeruginosa // Int J Mol Sci, 2013; 14(10): 20983-21005.

199. Weinstein M. J., Luedemann G. M., Oden E. M., Wagman G. H., Rosselet J. P., Marquez J. A., et al. Gentamicin, a new antibiotic complex from micromonospora // Med Chem, 1963; 6: 463-464.

200. Wiegering A., Sinha B., Spor L., Klinge U., Steger U., Germer C. T., et al. Gentamicin for prevention of intraoperative mesh contamination: demonstration of high bactericide effect (in vitro) and low systemic bioavailability (in vivo) // Hernia, 2014; 18(5): 691700 .

201. Wilton L. V., Pearce G. L., Mann R. D. A comparison of ciprofloxacin, nor-floxacin, ofloxacin, azithromycin and cefixime examined by observational cohort studies // $\mathrm{Br} \mathrm{J}$ Clin Pharmacol, 1996; 41: 227-284.

202. Wolfson J. S., Hooper D. C. The fluoroquinolones: structures, mechanisms of action and resistance, and spectra of activity in vitro // Antimicrob Agents Chemother, 1985; 28(4): 581-586.

203. Woodruff A. M., Hutmacher D. W. The return of a forgotten polymer Polycaprolactone in the $21^{\text {st }}$ century // 2010; 35(10): 1217-1256.

204. Wright J., Paauw D. S. Complications of antibiotic therapy // Med Clin North Am, 2013, 97(4): 667-679.

205. Wu P., Grainger D. W. Drug/device combinations for local drug therapies and infection prophylaxis // Biomaterials, 2006; 27: 2450-2467.

206. Xiong M. H., Bao Y., Yang X. Z., Zhu Y. H., Wang J. Delivery of antibiotics with polymeric particles // Adv Drug Deliv Rev, 2014; 78: 63-76.

207. Xu Q., Czernuszka J. T. Controlled release of amoxicillin from hydroxyapatite-coated poly(lactic-co-glycolic acid) microspheres // J Control Release, 2008; 127(2): 1461453.

208. Yamagami A., Nagaoka N., Yoshihara K., Nakamura M., Shirai H., Matsumoto T., et al. Ultra-structural evaluation of an anodic oxidated titanium dental implant // Dent Mater J, 2014; 33(6): 828-834.

209. Yu C., Giuffre B. Achilles tendinopathy after treatment with fluoroquinolone // Australas Radiol, 2005; 49(5): 407-410.

210. Zhang J. M., An J. Cytokines, inflammation and pain // Int Anesthesiol Clin, 2007; 45(2): 27-37. 


\section{PATEICĪBAS}

Vēlos izteikt vislielāko pateicību visiem cilvēkiem, kuri palīdzēja realizēt manu pêtījumu, it sevišksi saviem darba vadītājiem, kuri katrs deva savu ieguldījumu, vērtīgus padomus un stimulu darba realizācijā. No saviem darba vadītājiem ne tikai ieguvu padomus, bet esmu iemācījies vairākas vērtīgas lietas.

Liels paldies profesorei Jutai Kroičai par sniegto atbalstu, dotajiem padomiem un uzticēšanos visa pêtījuma laikā. Paldies, ka devāt jaunu un īsteno skatījumu uz pētniecību un darba darīšanu kā tādu.

Ļoti pateicos docentei Ilzei Šalmai par vērtīgajiem padomiem, palīdzību in vivo pētījumos un uzticēšanos manām darbaspējām. Paldies, ka devāt brīnišķo iespēju iesaistīties biomateriālu pētījumos.

Visdziḷākā pateicība ir manai ğimenei, kas izrādīja lielu sapratni gan pētījuma laikā, gan pēdējos mēnešos, pētījumu pabeidzot.

Paldies visam Bioloǵijas un mikrobiologijas katedras kolektīvam par palīdzību, kad tā bija tik nepieciešama no Jums. 
PIELIKUMI 


\section{E-testu fotoattēli}

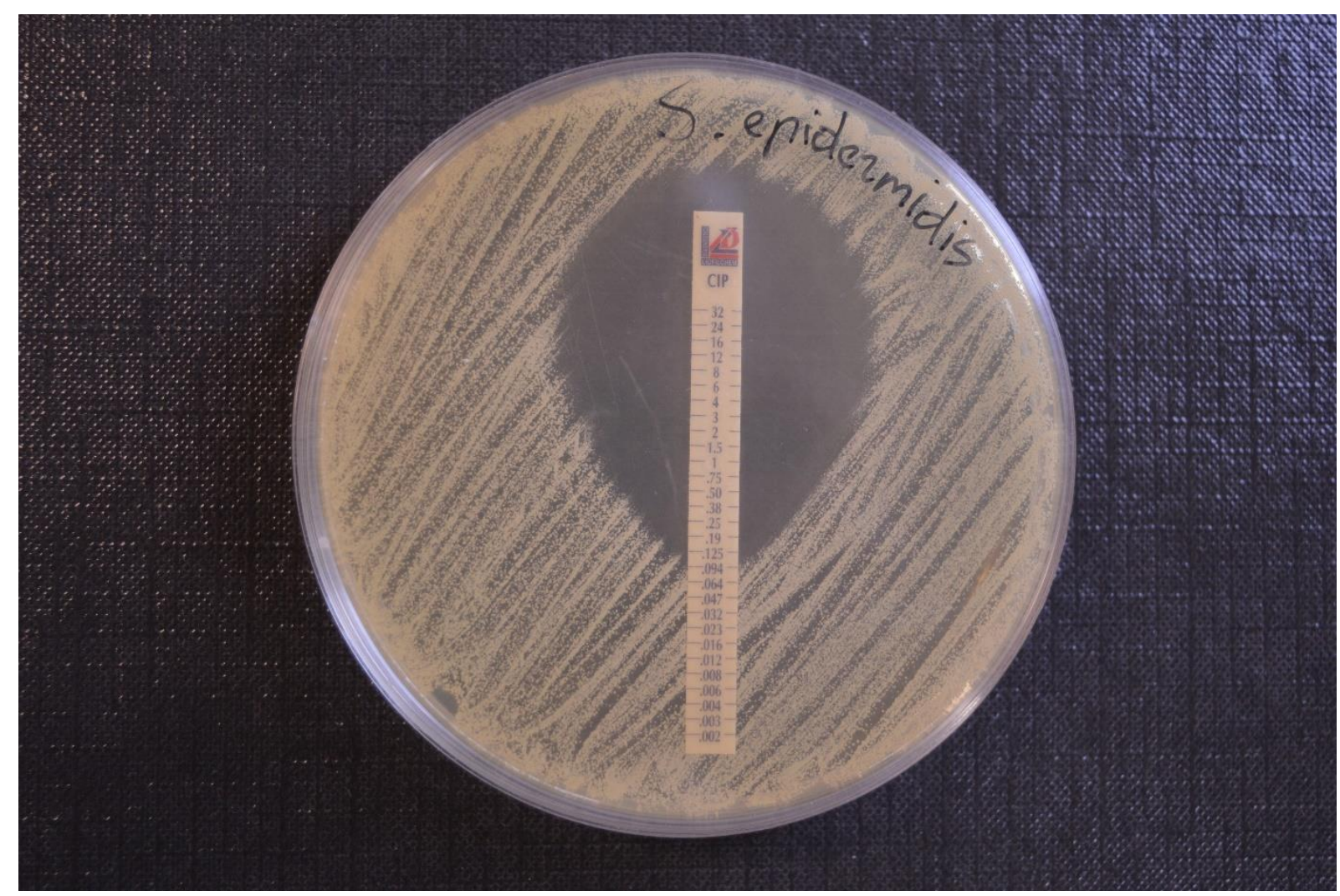

Ciprofloksacīna MIC pret $S$. epidermidis

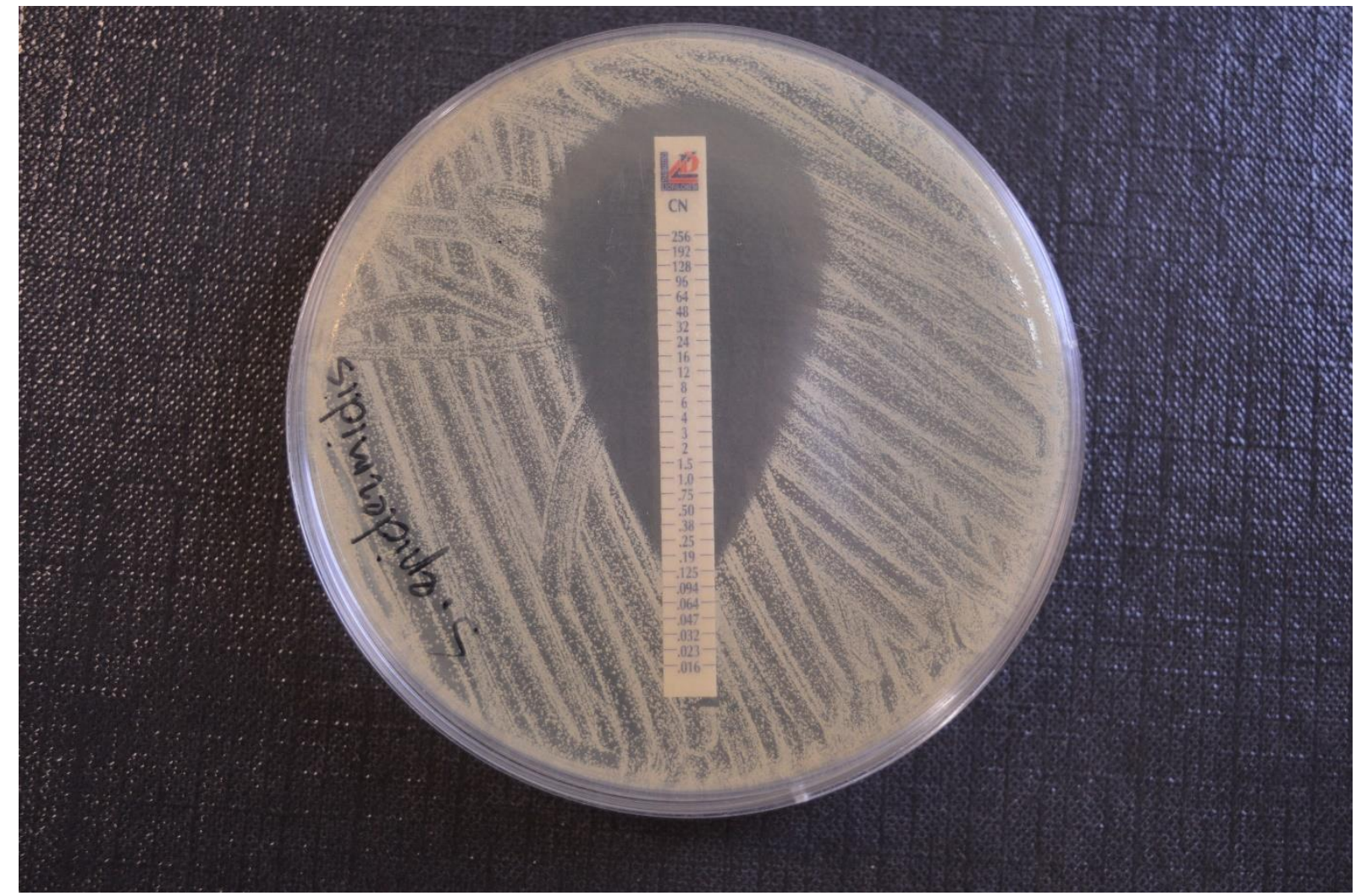

Gentamicīna MIC pret S. epidermidis 


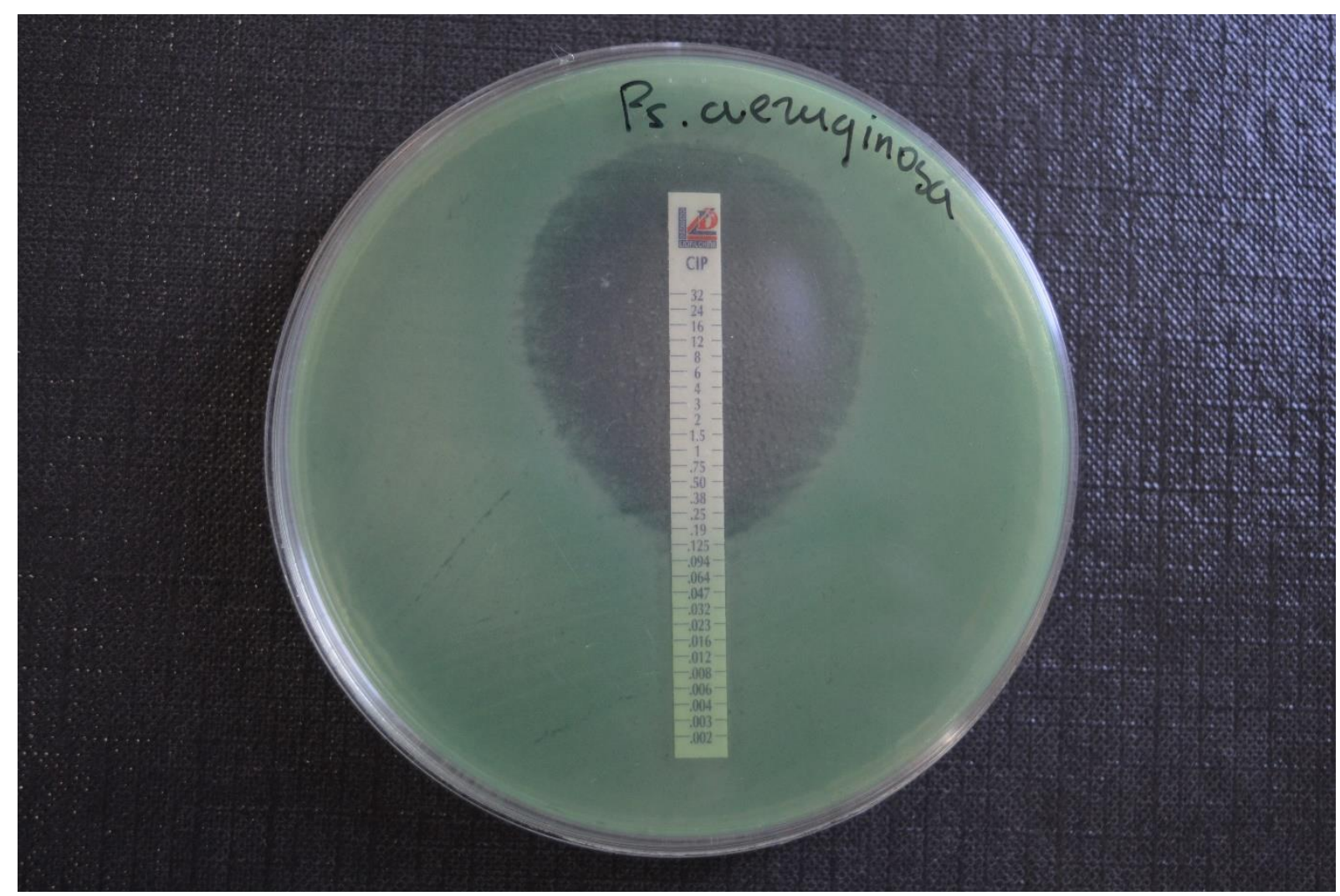

Ciprofloksacīna MIC pret Ps. aeruginosa

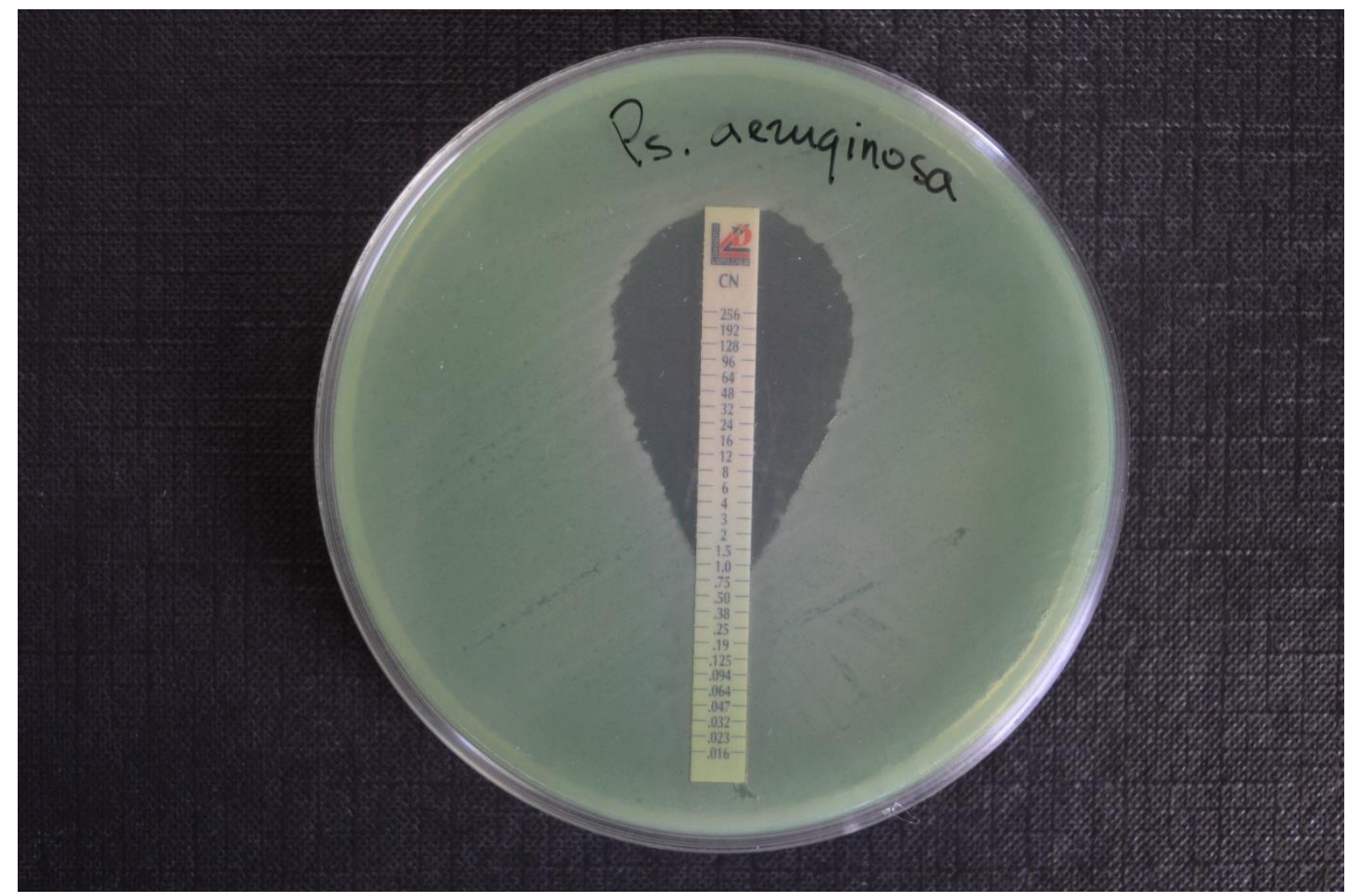

Gentamicīna MIC pret Ps. aerugino 


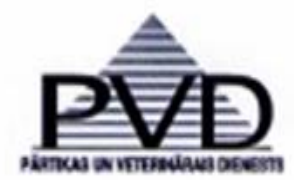

\section{PĀRTIKAS UN VETERINĀRĀ DIENESTA IZMÉGINĀJUMA PROJEKTA ATLLAUJA Nr. 24 DZĪVNIEKA IZMANTOŠANAI PROCEDÛ́RÃ}

At|aujas sapẹemejs:

\section{Rrgas Stradina universitate}

PVD reg.nr. 025479

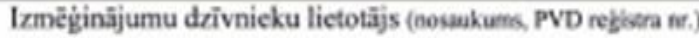

„Kaulaudus aizvietojošo sintętisku kalcija fosfäta biokeramikas biomaterialu reaktogenitate pęc implantäcijas eksperimentalu džnnieku audos, biomaterialu minimalas inficējošăs devas, mikrobiäläs kontaminäcijas riska un tã ietekmes uz kontaktejošo audu atbildes reakciju noteikšana".

Izměgèinäjuma projekta nosaukums

Generaildirektora pienskumu izpildrajs

$$
\begin{aligned}
& \text { 02.07.2010. Iidz 30.11.2012 }
\end{aligned}
$$

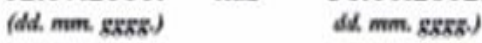

ED-2 astiet

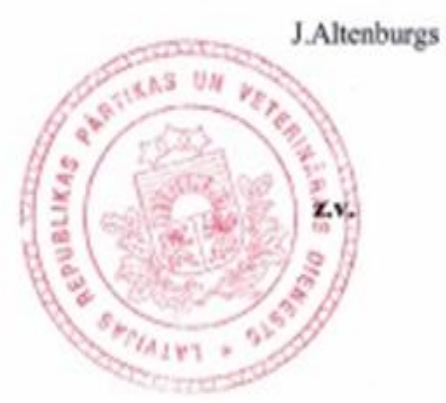

